\title{
Exploring the Factors Affecting the Purchase Likelihood of e-Tailer Private Labels
}

\author{
by \\ Y Yeswanth Reddy
}

A Thesis submitted in the fulfilment of the requirements for the degree of Master of Commerce (Marketing)

School of Marketing and International Business

Victoria University of Wellington 


\section{Acknowledgments}

I am using this opportunity to express my sincere gratitude to my research supervisor Dr. Djavlonbek Kadirov, M.Sc., Ph.D., Director Undergraduate Programme in Marketing, Victoria University of Wellington. It would have been very difficult to finish this project without his valuable guidance and feedback throughout the planning and writing of this research project.

Additionally, I would like to convey my gratefulness towards Dr. Janine Williams, M.Sc., Ph.D., Victoria University of Wellington, for her precious support, which was influential in shaping my research ideas and methods.

I am also thankful to Hannah Donmez and other wellington university staff for their unwavering support to finish this project.

A final thank you for the financial assistance from the Victoria University School of Marketing and International Business student research funding. 


\section{Contents}

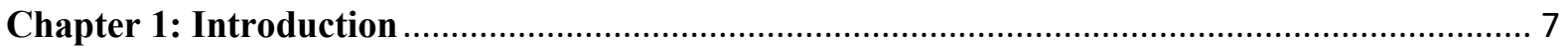

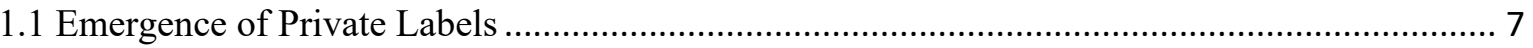

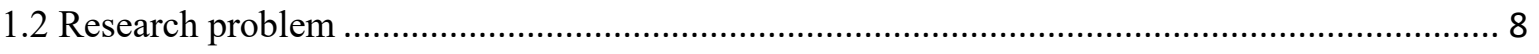

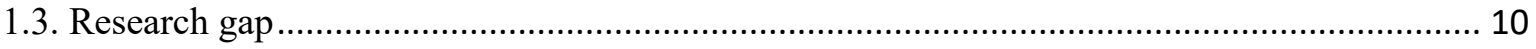

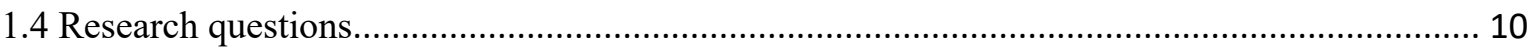

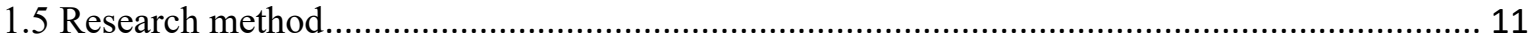

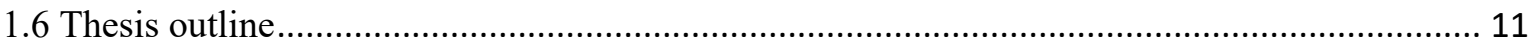

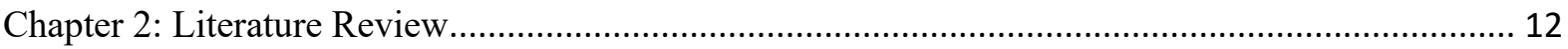

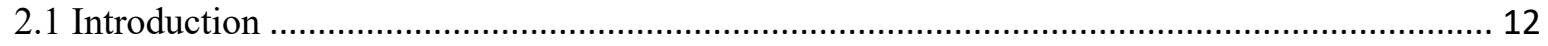

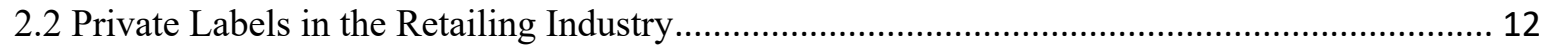

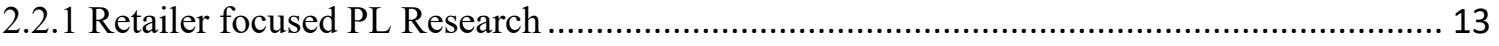

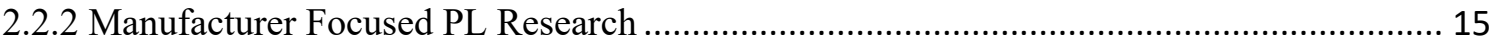

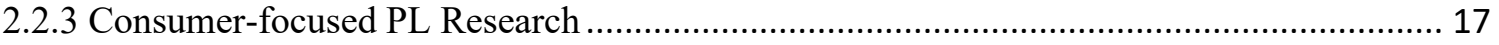

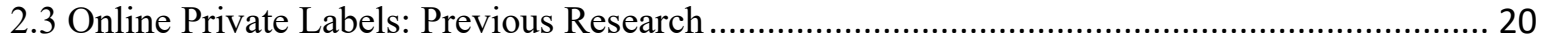

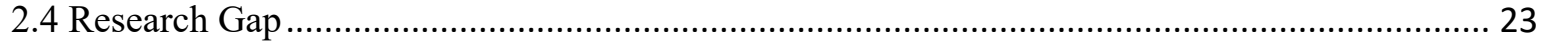

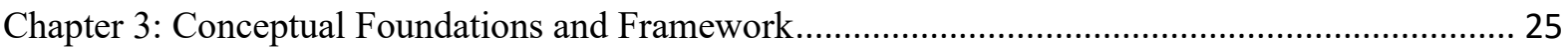

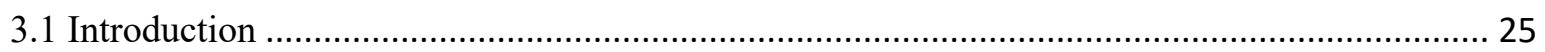

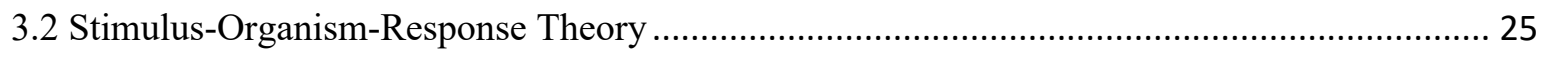

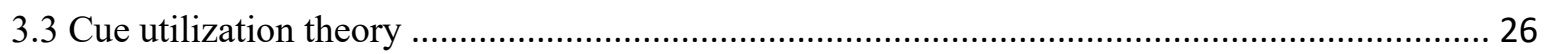

3.4. e-Tailer Reputation and Country of Manufacture Favourability............................................. 27

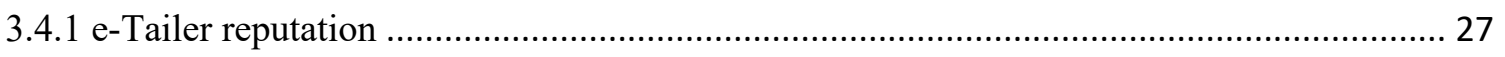

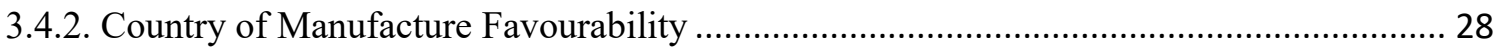

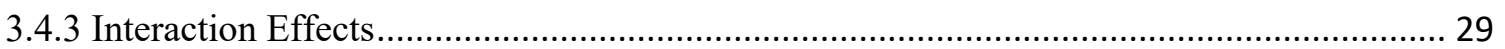

3.5 Online Consumer Ratings: PL Rating vs. Competitor Brands' Rating...................................... 30

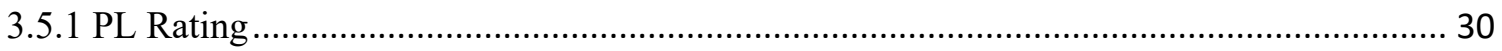

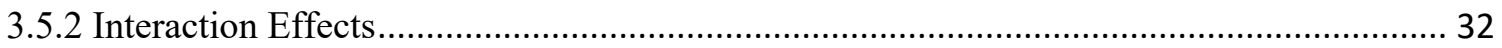

3.5.3 Conditional Effects: Competitor Brands' Online Ratings …............................................ 33

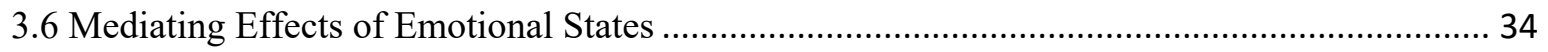

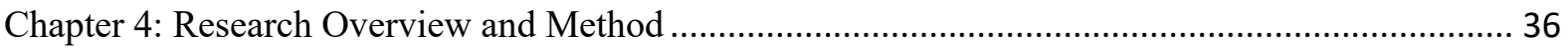

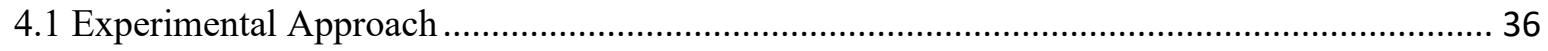

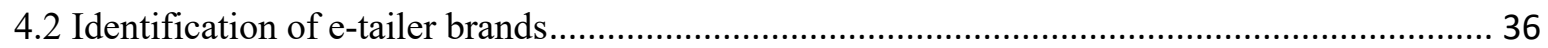

4.3 Identification of product categories and competitive brands ................................................. 37

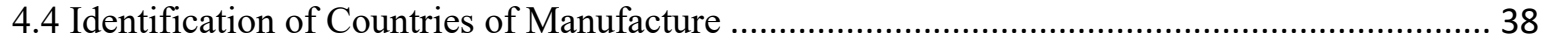

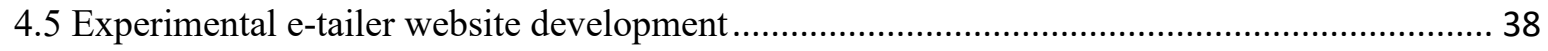

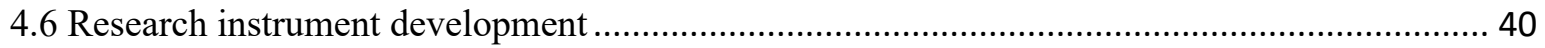


4.7 Data collection

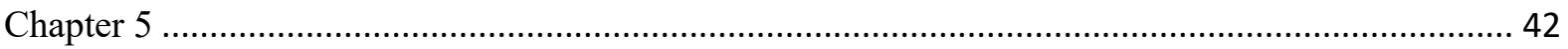

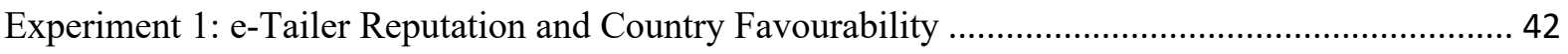

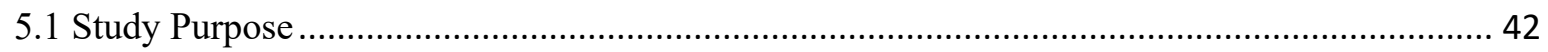

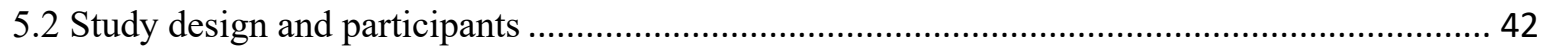

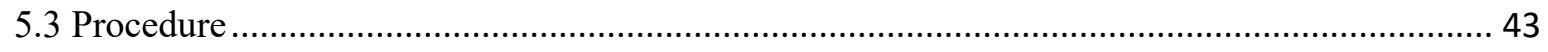

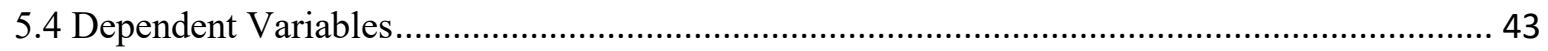

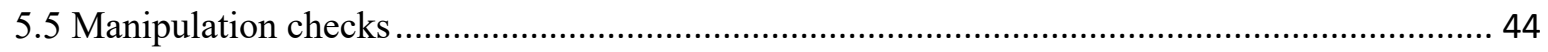

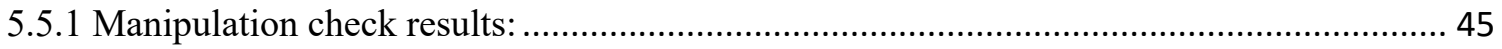

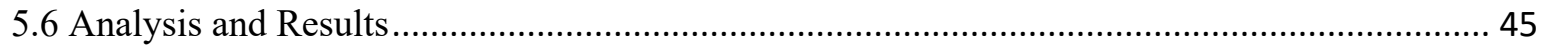

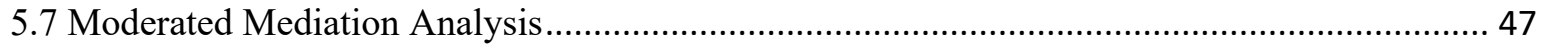

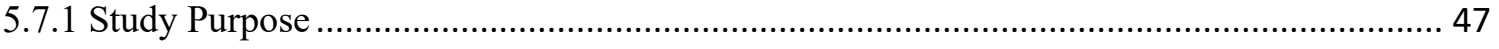

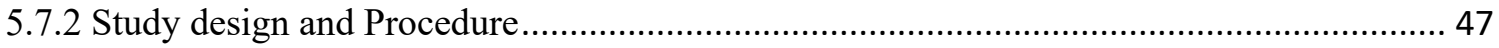

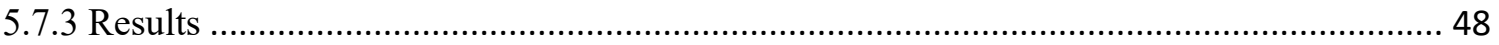

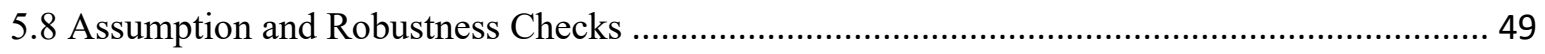

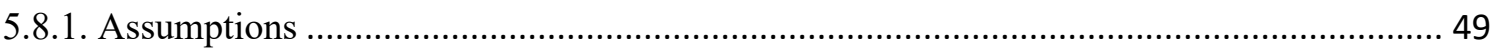

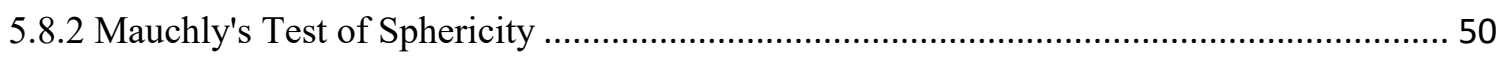

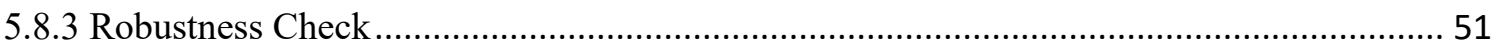

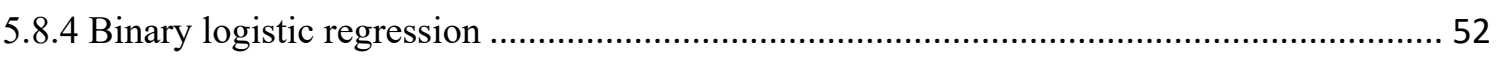

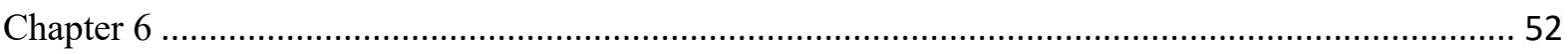

Experiment 2: e-tailer Reputation and Online Product Rating ...................................................... 52

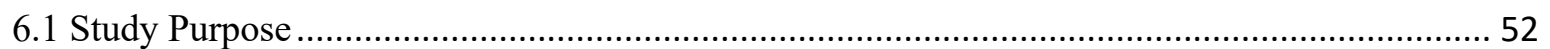

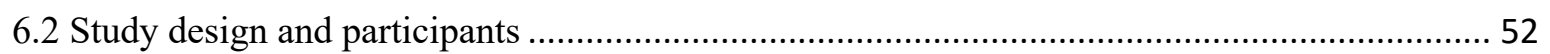

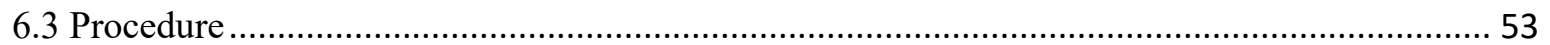

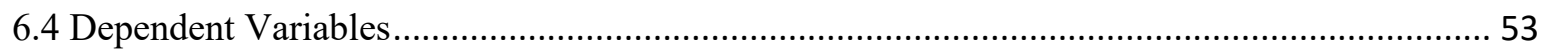

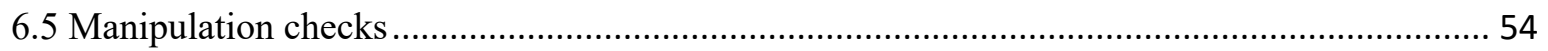

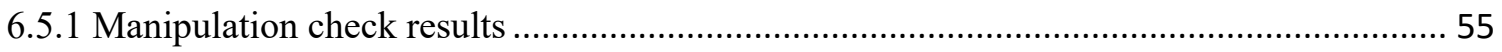

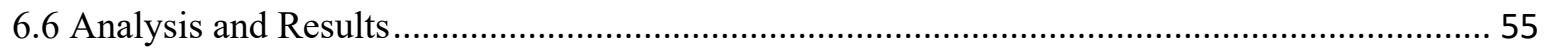

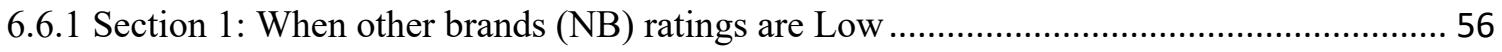

6.6.2 Section 2: When other brands (NB) ratings are high .................................................... 56

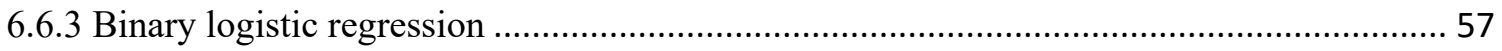

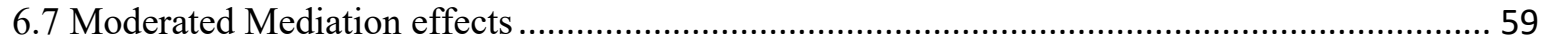

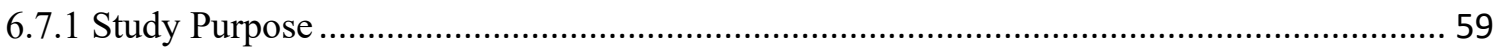

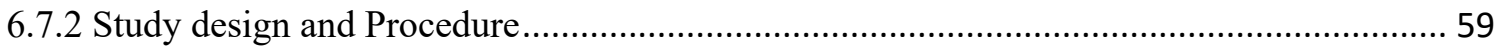

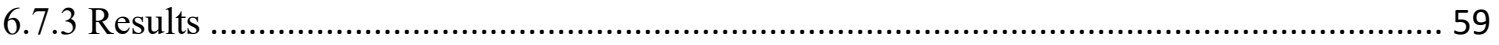

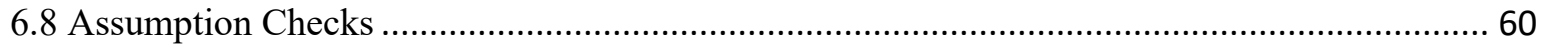




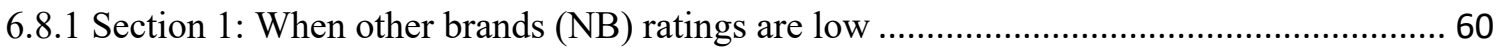

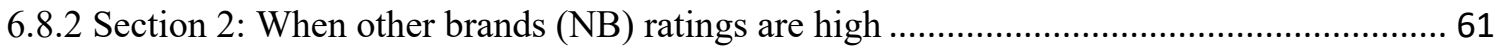

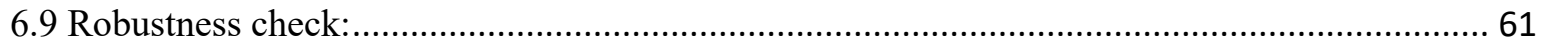

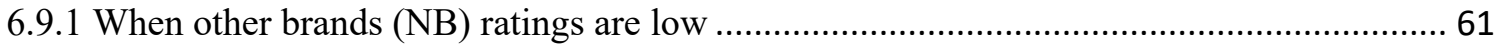

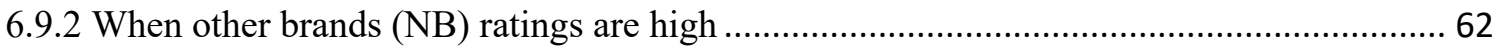

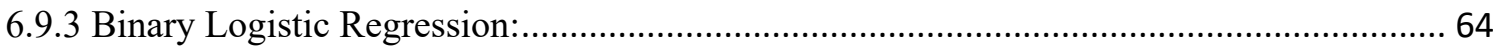

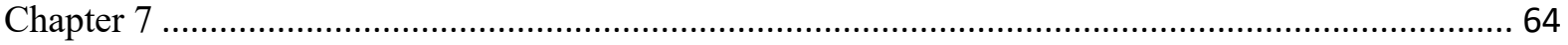

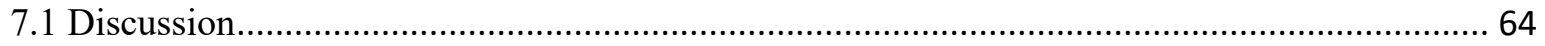

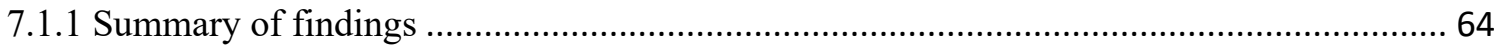

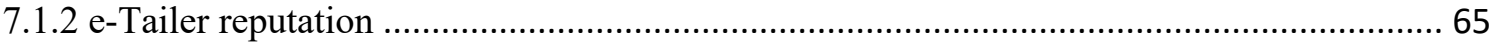

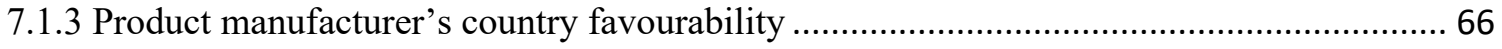

7.1.4 e-tailer reputation and country favourability interaction effect..........................................67 67

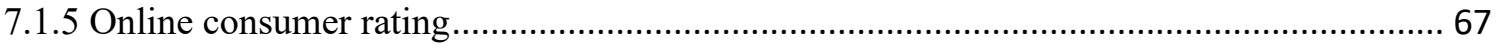

7.1.6 e-tailer reputation and online consumer rating interaction effect.......................................6 68

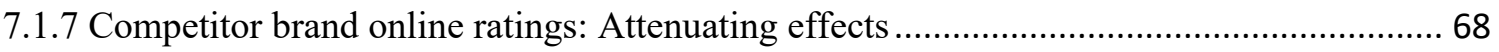

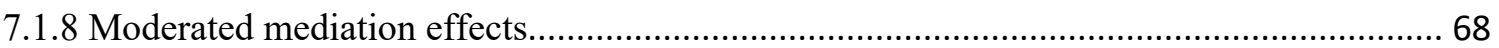

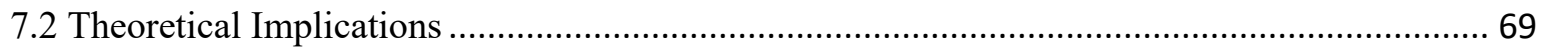

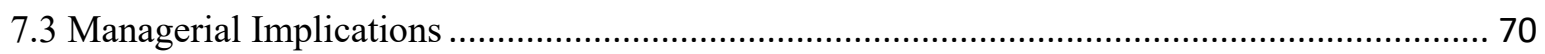

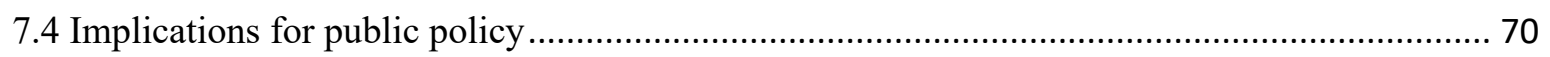

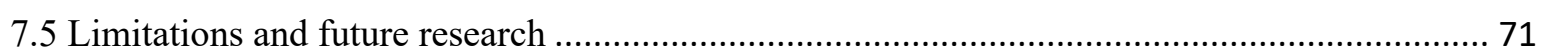

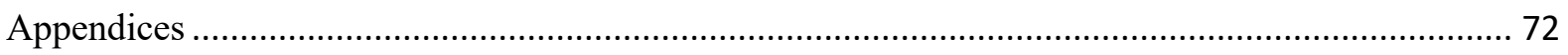

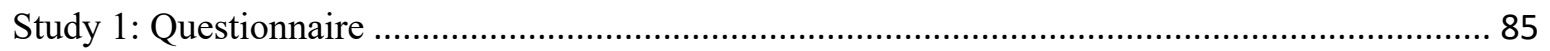

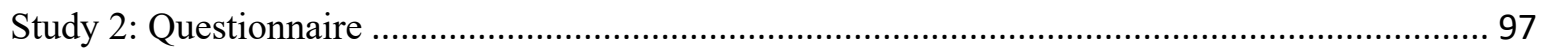

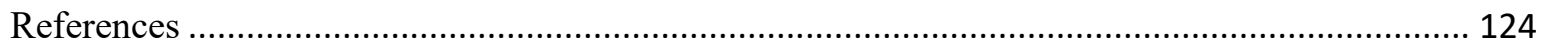




\section{List of Tables}

Table 2.1: Empirical research on Consumer PL for 1996- 2017 .............................................19

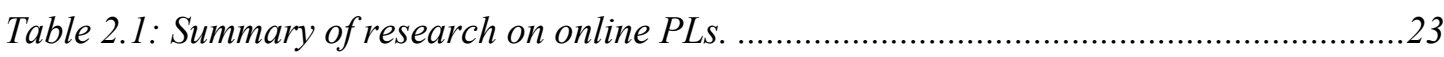

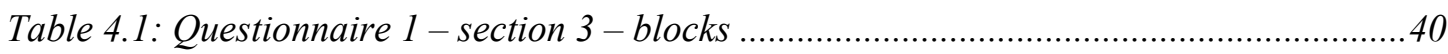

Table 4.2: Questionnaire 2 - section 3 - blocks.................................................................41

Table 5.1: Study 1 - Demographics of participants............................................................42

Table 5.2: Study 1: Tests of between subjects' effects............................................................

Table 5.3: Study 1: Binary logistic regression results..........................................................

Table 5.4: Study 1-Moderated mediation - Pleasure factor results.......................................49

Table 5.5: Study 1 - Moderated mediation - Arousal factor results.........................................49

Table 5.6: Mauchly's test of sphericity results...................................................................50

Table 5.7: Mauchly's test of sphericity - Robustness check results.........................................51

Table 5.8: Test of between subject effects - Robustness results.............................................51

Table 6.1: Study 2 - Demographics of participants................................................................53

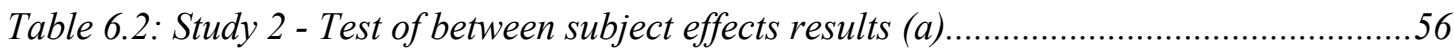

Table 6.3: Study 2 - Test of between subject effects results (b)..................................................

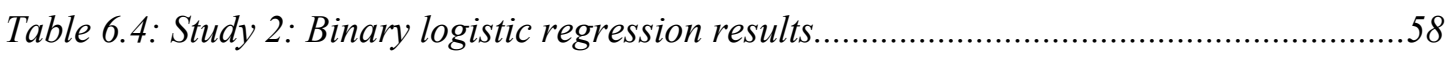

Table 6.5: Study 2 - Moderated mediation - Pleasure factor results......................................59

Table 6.6: Study 2 - Moderated mediation - Arousal factor results.......................................60

Table 6.7: Study 2 - Mauchly's test of sphericity results (a)..................................................60

Table 6.8: Study 2 - Mauchly's test of sphericity results (b)....................................................61

Table 6.9: Study 2 - Mauchly's test of sphericity - Robustness check results (a)....................62

Table 6.10: Study 2 - Test of between subject effects results - Robustness check (a...............62

Table 6.11: Study 2 - Mauchly's test of sphericity - Robustness check results (b)..................63

Table 6.12: Study 2 - Test of between subject effects results - Robustness check (b)..............64

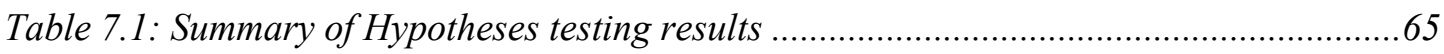

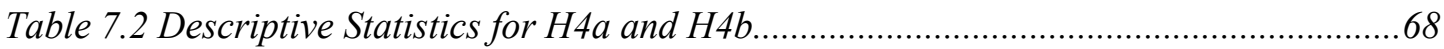




\section{List of Figures}

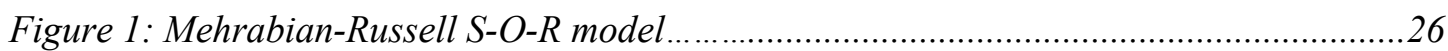

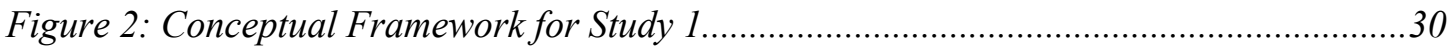

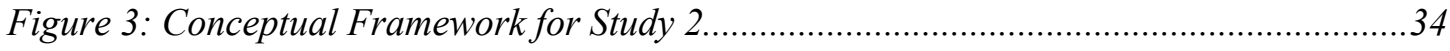

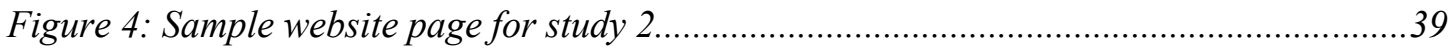

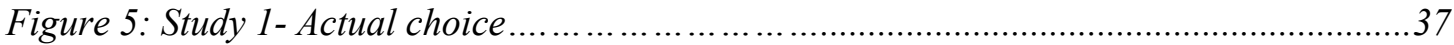

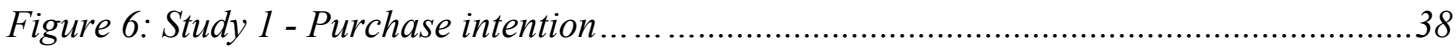

Figure 7: e-tailer reputation - Manipulation check question ....................................................45

Figure 8: Country favourability - Manipulation check question............................................45

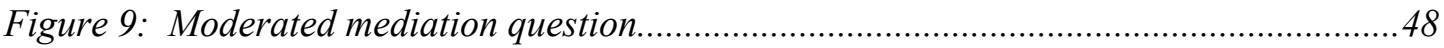

Figure 10: Study 2: Future purchase intention question.........................................................54

Figure 11: Study 2: Actual purchase intention question.......................................................5

Figure 12: e-tailer reputation - Manipulation check question ...............................................54

Figure 13: e-tailer reputation \& other brands - Manipulation check question ......................55

Figure 14: Intention vs Actual purchase of e-tailer PLs....................................................69 


\section{Chapter 1: Introduction}

This thesis focuses on the area of growing interest to academics and retail managers, namely online or e-tailer private labels (PLs). In the retailing context, consumer packaged goods are either labelled as national brands (NBs) or private labels. It is known that "NBs are generally owned by manufacturers and are sold in various retail stores/general trade. PLs, sometimes called bargain goods, are owned by retailers or distributors and are sold privately in their stores for less price than national brands" (Bushman, 1993, p. 857). But this notion has changed over time, and PLs are not viewed as low-cost alternatives to NBs anymore. Instead, they are meeting consumer needs by offering high-quality products at different price points (Nielsen, 2014).

This chapter begins with a brief discussion on the rise of PLs, followed by the explanation of the gaps in current PL research. It then describes the research questions and presents the outline of this thesis.

\subsection{Emergence of Private Labels}

PL products are a group of consumer products sold under a brand name owned by the retailer or its parent company. These brand products are either sold exclusively in a store or in the member stores owned by the parent company (Private label today, n.d.).

Retailer private labels are also named as own brands, store brands, or distributor-owned brands (Kumar \& Steenkamp, 2007). Traditionally, PLs are considered as value for money but are now a significant competitor for NBs, which is particularly evident in packaged goods products (Nenycz-Thiel \& Romaniuk, 2016). Store expansions by major retailers in the past decade have given consumers more access to PLs, which is one of the main reasons PLs are gaining market share across all major geographies (Nielsen, 2018). PL offerings have changed from being an alternative for a low-value product to retailer brands offering high-quality products that have become substitutes for NBs (Burt, 2000). The value share of PLs across the world was around $16.7 \%$ in the year 2016 (Nielsen, 2018). Simultaneously, the value share was highest in EU countries with 31.4\% in 2016 (Nielsen, 2018). Even in the EU region, some countries like Switzerland (49.6\%), Spain (49.5\%), and UK (46.8\%) have got the highest share, whereas Italy $(22.3 \%)$ and Poland (30.6\%) have seen the lowest percentage (Coppola, 2021). This phenomenon clearly shows that NBs in many countries face massive competition from PLs 
(Cuneo et al., 2015). PL sales increase when the economy is struggling, as shoppers tend to reduce their expenses and look for cheaper alternatives (Nielsen, 2018). A report released in 2014 found that about $60 \%$ of consumers across 55 countries turn towards PL brands to reduce household expenses due to the economic downturn (Nielsen, 2014). (Kumar \& Steenkamp, 2007) observed that some portion of PL growth that occurred during a recession is permanent, and the cause for that is consumer learning about the quality of PLs. Gómez et al. (2017) pointed out that after the economic crisis in 2008, PLs have gained consumers compared to NBs, especially in developed countries.

The importance of PLs grow during recessions because of less disposable income of shoppers and lower prices (Walsh \& Mitchell, 2010). However, customers may not be willing to go back to NBs even after improved economic conditions (Huang \& Feng, 2020; Mishra et al., 2020). Over a while, PLs have risen from being a low-cost me-too product to premium products that offer quality goods at par with high-end national brands (Geyskens et al., 2010). To reach a broad customer base Information Resources Inc. (2007, p. 30) recommended that retailers should expand into three-tiered quality offerings. This approach includes having an economy, standard, and premium categories of in-store brands. Nenycz-Thiel and Romaniuk (2015) also mentioned in their study that PLs could be classified as a value, mid and premium PLs. Economy or value PLs are low-priced product ranges that save on expensive ingredients to reduce costs (Geyskens et al., 2010). Standard PLs are copy-cats of leading NBs (Kumar \& Steenkamp, 2007) where the packaging is similar to well-performing NBs, and these products delivered good margins to retailers as copy-cat PLs gained through the quality promises carried by NBs (Nenycz-Thiel \& Romaniuk, 2015). Premium PL's are the most recent development stage in the PLs category. These products are equal to that of premium quality NBs while usually still selling for a slightly lower price (Geyskens et al., 2010). Corstjens and Lal (2000) opined that premium PL's were introduced to set stores apart from each other. Also, because store brands are generally sold at a lesser price than the average price, the market share by volume is higher than the market share in value (Bergès-Sennou et al., 2004).

\subsection{Research problem}

The emergence of the Internet and e-commerce has changed the way how marketers carry out business operations and promotional activities like marketing and advertisement (Mohapatra, 2013). This phenomenon has led to the emergence of many online retailers (e-tailers). The platform eMarketer reports an estimated global e-commerce sale of $\$ 3.535$ trillion in 2019. The 
same report expected that the sale would reach $\$ 5$ trillion by 2021 (Lipsman, 2019). Another report on the market share of leading e-tailers by Coppola (2020) states that Alibaba's Taobao.com ranked first with 15\% gross merchandise volume (GMV), followed by Amazon with $13 \%$ for the year 2019. As the virtual marketplace becomes more crowded, e-tailers like Amazon and Flipkart now have their own brands or PLs to earn higher revenues and strive in the competitive market. PLs help e-tailers attract repeat shoppers and improve margins (Tandon, 2020). A report from KPMG (2020, p. 1) states that PLs are "expected to grow 1.3 to 1.6 times faster than e-commerce platforms".

Renfrow (2017) mentioned that $80 \%$ of consumers' first search online even if they are making purchases in physical stores. e-tailers like Amazon are taking advantage of this phenomenon to push their PLs by placing their own brands in the slots where visibility is high (Dudley, 2020). Marker editors (2020) report reveals that Amazon sells 22,617 PL products under different brand names like Amazon Basics, Solimo, 206 Collective, and Amazon essentials, etc. While responding to criticism, Amazon mentioned that their PL products account for only $1 \%$ of their total sales (Marker editors, 2020). So, based on the reports from Lipsman (2019) and Coppala (2020), it can be estimated that Amazon sales from its PLs in the year 2019 is around $\$ 4.5$ billion.

The above data shows the growing importance of PLs to e-tailers in the fast-growing ecommerce market. Also, the growth of e-commerce and its potential to grow further in the future have provided small players an opportunity to grab a share of mounting online sales. But, there is a huge entry barrier in the form of competition from established players like Alibaba, Amazon, Flipkart and others. The growing number of small e-tailers is also a problem to established players as they are losing some part of their market share to small players and new entrants. In this situation, it is essential for both established players and small businesses including new entrants to understand different aspects of shoppers' behaviour towards online PLs. For example, how do customers assess new e-tailer products versus established e-tailer products? Is it just the price and quality of the product that attract customers or do other extrinsic factors such as the e-tailer reputation, place of product manufacture and, product online ratings have an effect on shoppers' behaviour?

Hence it is very important for academics and managers to understand how consumers respond to the e-tailer owned PLs. 


\subsection{Research gap}

Although the subject of PLs has long been studied, the focus was more on traditional retailer PLs. Research on e-tailer owned PLs is minimal. Though there are some studies on online PLs from researchers like Arce-Urriza and Cebollada (2012) and Dawes and Nenycz-Thiel (2014), they have studied the performance of PLs owned by traditional retailers against NBs. Parsons et al. (2012) investigated country-of-origin effects on the purchase likelihood of PLs using an online website. Dawes and Nenycz (2014), as a part of their research, examined the performance of PLs in an online environment compared to a traditional store environment.

However, all these studies have used PLs owned by traditional retailers selling their products on an online platform, but not the PLs that are sold exclusively in online stores. Moreover, all the investigations used PLs from the grocery sector. Research from Kumar and Chandra (2020) is the only study that has used virtual retailers or e-tailers to examine the consumer purchase intention towards e-tailer PLs by developing a purchase intention framework. But, they did not study these effects using any specific industry. Research shows that results from investigations on purchase behaviour in grocery industry cannot be generalised to purchase behaviour in other sectors" (Vahie \& Paswan, 2006, p.70). Hence, this research attempts to fill the gap and study the effects of different extrinsic factors such as e-tailer reputation, country favourability, and consumer online ratings on the consumer purchase likelihood of e-tailer owned PLs in the electronic industry.

\subsection{Research questions}

This manuscript's primary purpose is to investigate the effect of e-tailer reputation, product manufacturer's country favourability, and consumer online ratings on the purchase likelihood of e-tailer PLs using the S-O-R framework (Mehrabian \& Russell, 1974). The research problem explored in this study is:

Do extrinsic factors like e-tailer status, manufacturing country, and product online rating have an impact on the purchase likelihood of PL products?

The following research questions were investigated to answer the research problem:

a) Does e-tailer reputation have an effect on purchase intention? How is this effect different for the actual purchase of PL products?

b) Does the product manufacturer's country favourability affect purchase intention? How is this effect different for the actual purchase of PL products? 
c) Do consumer online rating and competitor online rating impact purchase intention? How are these effects different for the actual purchase of PL products?

\subsection{Research method}

I have used the experimental research design for this thesis. I developed a website and provided access to that website to the respondents using hyperlinks in the questionnaire.

A self-administered questionnaire with different scenarios was developed for each experimental condition using existing scales as measures and distributed through an online crowd-sourcing platform for collecting responses from US residents.

To assess the influence of e-tailer reputation on PL purchases, I used two brands, Amazon and DigiShack (imaginary brand), along with four other national competitor brands. To comprehend the manufacturer country's favourability, two countries China and Mexico, were used as visible online labels. Finally, to understand the effects of consumer online ratings, different scenarios were created where the brands (both PL and competitive brands) were presented with high or low ratings. Respondents were randomly presented with one of the scenarios in the questionnaire. In chapter four, I have explained in detail how the scenarios were created. Also, the website development process and the basis of the selection of brands and countries are discussed.

To analyze the data and test the proposed hypotheses, I have used mixed design repeated measures, binary logistic regression, and Hayes moderated mediation models using SPSS. It is expected that the results from this study can offer some important insights for both e-tailers and manufacturers.

\subsection{Thesis outline}

This thesis is divided into seven chapters. This introductory chapter is followed by the literature review. The second chapter examines the previous research on PLs in the traditional retailing industry and existing literature on online PLs.

In chapter three, the underlying foundations for hypotheses development and the conceptual framework of this thesis are explained in detail. This section also examines previous research on the S-O-R framework, product manufacturers' country, and online consumer ratings.

Chapter four discusses important elements like the approach followed in this study, how the etailer brands, competitor brands, and product manufacturers' countries are selected, why an 
experimental website is developed, and which product categories are used to collect data. This chapter also describes how questionnaires are developed and sent for data collection.

Chapters 5 and 6 comprise the experiment's purpose, processes, hypotheses testing, and results of data analysis, including robustness checks to validate the quality of data. The number of responses received and participants' profiles are described.

In the final chapter, results derived from the analysis are thoroughly discussed. The implications of the findings for academics, study limitations, and future research proposals are also specified in this chapter.

\section{Chapter 2: Literature Review}

\subsection{Introduction}

This chapter focuses on the existing literature on online private labels (PLs) and is organised into two sections. The first section reviews the importance of (PL) brands in the retailing industry by overviewing the significance of PLs for retailers, manufacturers, and consumers. The second section covers the review of existing research on online PLs.

\subsection{Private Labels in the Retailing Industry}

Research on store brands or PLs has been of significant interest to marketing researchers for more than four decades (Narasimhan \& Wilcox, 1998), particularly since the 1990s. Since the pioneering study by (Myers, 1967), scholarly research on PLs has been remarkably growing, especially in the last twenty years (Gómez et al., 2017). Hoch and Banerji (1993) state that PLs success is influenced by the actions and expectations of three players: a) manufacturers, b) consumers, and c) retailers.

Retailers and consumers define the demand and supply side, whereas PL brands' competition depends on NB manufacturers' actions. Altinta et al. (2010) also classified previous studies on private labels into three categories:

- Consumer-based studies (Sinha \& Batra, 1999; Batra \& Sinha, 2000; Corstjens \& Lal, 2000; Baltas, 2003; Miranda \& Joshi, 2003; Vahie \& Paswan, 2006).

- Comparisons between NBs and PLs (Bontemms et al., 1999; Steiner, 2004; Narasimhan \& Wilcox, 1998; Burt, 2000; Bonano \& Rigoberto, 2005; Ailawadi et al., 2003; Hultman et al., 2008).

- Manufacturer-related studies (Oubina et al., 2006; Gomez \& Benito, 2008). 
Through their research, Hyman et al. (2010) stated that since 1990 there have been about seventy-three PL-based empirical and theoretical articles published according to the business source premier database. Those articles can be classified into consumer-focused, retailerfocused, market structure-focused, manufacturer-focused, and joint retailer-manufacturerfocused. According to previous data, PL studies can be broadly categorized into: retailer focused, manufacturer focused and consumer-focused.

Previous research has shown that the key driver for the growth of PLs in developed countries is because of the intense competition between retailers and manufacturers (Hoch, 1996; Burt, 2000; McGoldrick, 2002; Tarzijan, 2004; Amrouche \& Zaccour, 2007; Herstein et al., 2017).

\subsubsection{Retailer focused PL Research}

Research has presented multiple reasons why retailers consider establishing PLs. one is that retailers tend to introduce PLs in a category to increase direct profits and use them as a bargaining weapon to obtain concessions from the NB manufacturers (Narasimhan \& Wilcox, 1988; Herstein et al., 2017). PLs can also contribute to the retailers' overall image (Ailawadi et al., 2008; Herstein et al., 2017). These days, many retailers are shifting their PL offerings to more upmarket premium brands to improve their store personality and the image they wish to portray to their consumers (Huang \& Huddleston, 2009; Herstein et al., 2017).

Motivation to develop PLs occurs when retailers can derive more economical or strategic benefits (Altinta et al., 2010). Previous research has learned that having favourable market conditions that can increase profits and growth, improve store image and build distinction from competitors is another factor that encourages retailers to introduce PL's (Corstjens \& Lal, 2000). Existing literature states that if the price difference between PLs and manufacturer brands is high, then this phenomenon leads to higher store brand sales (Sethuraman, 2000). From the economic perspective, if retailers can keep their expenditure under control, PLs can provide higher margins and offer customers higher price gaps than manufacturer brands (Ailawadi \& Harlam, 2004). Rubio and Yagüe (2009) stated that to increase consumer demand for PLs, retailers must create price differentials between manufacturer brands and PL brands, particularly for price-sensitive customers. Even though in many product categories, consumers are willing to pay a higher amount to purchase manufacturer brands, a higher price gap between PLs and NBs can be a reason for shoppers moving towards store brands (Steenkamp et al., 2010). PLs have the potential to boost the overall product category profits even in the categories with higher NBs presence (Vahie \& Paswan, 2006). Narasimhan and Wilcox (1998) also stated 
that higher PL penetration levels lead to a higher overall category margin. Attractive PL brands and PL price promotions have got potential to increase primary demand and even expand NB sales (Cheng et al., 2007; Huang et al., 2007; and Hyman et al., 2010).

Philipsen and Kolind (2012) identified seven main reasons why retailers may get involved in PLs. They are:

- monetary motivations such as increasing turnover, margins, etc.,

- building store loyalty and image

- to provide customers with different price options and also to be able to fight competition

- to increase negotiation power by gaining more knowledge on manufacturing costs

- to cover some special segments that could not be reached otherwise

- to improve members' dependency

- export of PLs

A French survey report from Fournier (1996) says that with the introduction of PLs, retailers can compete for both with their competitors (increase consumer loyalty, improve positioning) and suppliers (improve margins, lower prices) (Bergès-Sennou et al., 2004). Through store brands, retailers can attract price-sensitive consumers looking for lower-cost NB substitutes and differentiate themselves from other chains (Hyman et al., 2010). Because of their diversified presence, large retailers can access information on consumer purchase patterns and product movement within the supply chain. Owing to this information, influential retailers can reconfigure functions and tasks within the traditional supply chain. This information power also supports retailers in developing image development by creating differentiation in the marketplace and offering products available only in their stores (Burt, 2000).

If the quality of a PL is as good as NB, it leads to more PL sales. Hoch and Banerji (1993) proved through their research that the most crucial factor influencing PL share is 'Quality.' PLs with premium quality have the potential to minimize the need for a PL brand to maintain its prices lower than national brands (Sethuraman \& Raju, 2012). Retailers can create a clear, positive image and market position in customers' minds by transferring most operational decision-making such as promotions, product mix, pricing, merchandising, and store layout to more of a corporate centre rather than operating from a store or region (Burt, 2000). They can increase consumer acceptance for PLs by merely enhancing the extrinsic cues correlated with store labels, such as improvements in packaging design, labelling, advertising, and branding 
strategies. European retailers have realised this and have been successful in enhancing PL market share (Richardson et al., 1996). The European experience also shows that retailers can create a competitive advantage by properly marketing store brands (Dick et al., 1995).

The introduction of new products under a PL poses many risks to the retailer as PL brands are basically umbrella brands with various product categories. Therefore, a consumer's negative experience in one product category will affect purchases in other product categories and the chances of losing shoppers' confidence towards the store as a whole (Thompson, 1999). Hence, the larger the number of categories sold under the umbrella brand, the higher the occurrence of adverse spill-over effects is higher (Sullivan, 1990; Semeijn et al., 2004). There is significant previous research to demonstrate the positive impact of shelf space allocation and sales performance (Lim et al., 2002; Dubelaar et al., 2001; Nogales \& Suarez, 2005). Hence, providing better shelf space to PLs than NBs helps increase visibility and purchase likelihood (Herstein et al., 2017).

\subsubsection{Manufacturer Focused PL Research}

Traditionally, NBs have followed a differentiation strategy or an image-oriented strategy, whereas PLs have stuck to a low-price strategy or employed a value-for-money strategy (Verhoef et al., 2002; Porter, 1976). The introduction of store brands has changed the relationship between manufacturers and retailers as retailers will become both manufacturers' clients and competitors in production (Tarziján, 2004). Hoch (1996) also termed retailers or organisations owning PLs as both competitors and customers to NB manufacturers. There are both gains and losses to manufacturers from producing PLs. For example, revenues would be derived by achieving scale economies from NB and PL production. Losses would occur through cannibalization of own NB sales and in-sufficient store brand-related profits (Hyman et al., 2010). Producing PLs also helps manufacturers in maintaining excellent and profitable relations. Sustainable and long-term relationships with retailers lead to a sustainable competitive advantage by creating a win-win situation (Kalwani \& Narayandas 1995).

Burt (2000) says that manufacturers' willingness to comply with retailers' requirements happens in order to maintain economies of scale, cover fixed costs, and to utilize full production capacity. Manufacturers have the power to increase the wholesale prices offered to the retailer depending on the amount of market share that particular retailer is stealing in the category with the introduction of PL (Narasimhan \& Wilcox, 1998). Product category prices go up when an 
NB manufacturer supplies quality products to the retailer as this gives market power to both the manufacturer and retailer (Mills, 1995). When both the manufacturer and retailer are involved in product innovation and development, the possibility of switching suppliers is more petite, particularly in the strategically more important markets where there are higher margins (Burt, 2000). Raju et al. 1995 state that if PL and NB's price substitutability is high, it favours store brands' introduction, whereas, if the price competition between NBs is high, it discourages retailers from introducing PLs as this phenomenon reduces PLs price and retail margins and also leads to a reduction in category profits to the retailer (Sethuraman \& Raju, 2012).

Over some time, due to the narrowing of the quality gap between PL and NB products, a need for new strategic reactions from leading manufacturers is required to face a new reality (Morris\& Nightingale, 1980; Verhoef et al., 2002). Hoch (1996) was the first to discuss the strategic options that NB manufacturers can adopt to deal with retailers owning PLs, but this information is mainly anecdotal evidence. The six strategic options from Hoch, (1996) based on quality and price dimensions are:

- increasing distance from PL's through new and improved offerings

- increase the distance from private label through offering "more for the money

- reduce the price gap

- formulate a me-too strategy by introducing a value flanker

- wait and do nothing

- produce premium private labels (Hoch, 1996; Verhoef et al., 2002).

Some leading NB manufacturers argue that retailers confuse customers by developing look-alike products with similar packaging and labeling attributes such as colour, shape, size, logo, graphics, etc. (Kapferer, 1995; Balabanis \& Craven, 1997). Rafig and Collin (1996) found that the copycat packaging of PLs has created a lot of confusion for consumers. However, an empirical study by Balabanis and Craven (1997) did not find any evidence to support the assumption that consumers purchase store brands by mistake because of look-a-like characteristics of NB's.

Hoch (1996) opines that PLs should be considered to function like any other brand in a category as consumers must make choices between quality and price while deciding on which brand to choose when all brands, including PLs, occupy positions in a quality and price product space. 
The market share of a PL is negatively affected if the quality gap between PLs and NBs is larger (Hoch \& Banerji, 1993).

PLs are often featured as basic functional products with no information identifying the manufacturer (Dick et al., 1995; Porral \& Lang, 2015). However, a retailer providing manufacturer information on the package while other retailers are not doing it may influence consumer loyalty, evaluations, and purchases of retailer-owned brands. Mentioning manufacturing details by the retailer also allows consumers' to associate and connect specific PL products with an identified manufacturer boosts consumer confidence, thereby reducing the perceived risk (Porral \& Lang, 2015). NB manufacturers' share of special offers will have a considerable positive impact on NBs market share, whereas this will have adverse effects on the market share of PL's (Olbrich et al., 2017; Brüggemann et al., 2020). Nenycz-Thiel (2011), through their investigation, found that the difference in penetration of store brands can depend on differences in the intensity of advertisement.

\subsubsection{Consumer-focused PL Research}

There has been a focus on PL brands research with multiple aims since the $1960 \mathrm{~s}$. The preliminary research from (Frank \& Boyd, 1965; Myers, 1967; Burger \& Schott, 1972) focused on characterising store brand customers. Researchers considered different variables such as socio-demographics, psychographics, lifestyle, behavioural, and personality traits in order to study store brand consumers (Martínez \& Montaner, 2008). Suárez et al. (2017) found that academic research on PL consumers' perspective has been on an increasing note from the past ten years. Research by Myers (1966) found that PL buyers are generally more enthusiastic and sensitive compared with NB buyers. Another research on personality characteristics on PL brand attitude by Becherer and Richard (1978) found that PL buyers are more independent in their decisions. They are not affected by the behavioural norms of others.

In PL research, the results from studies on socio-demographic variables are not absolutely definitive. Some studies found that young customers widely use PL products (Dick et al., 1995; Omar, 1996), whereas Richardson et al. (1996) and Burton et al. (1998) did not find any substantial relationship between age and PL purchases. Similar contradicting results are also seen for variables such as household incomes and education. Household size is the only variable with similar results in all the studies (Dick et al., 1995; Omar, 1996; Richardson et al., 1996), i.e., families with more people purchase PL brands repeatedly. 
Consumers' familiarity with retailer's PL products positively influences the purchase of PLs as buyers who are familiar with store brand products and consider them as good quality and low-risk products. Whereas consumer dependence on extrinsic cues such as packaging and brand name inversely affects PL product purchases (Richardson et al., 1996). Dick et al. (1995) also stated that familiarity with the PLs gives confidence to store brand-prone consumers as it helps them avoid products that do not meet their requirements. Price-conscious shoppers are more prone to buying PLs as the cost of the product is the deciding factor in their purchases, and they focus only on a lower price, ignoring other product characteristics (Baltas \& Doyle, 1998; Hansen et al., 2006; Martínez \& Montaner, 2008). Non-buyers of PL products believe that purchasing PLs may result in a monetary loss as they consider those products are of inferior quality. Moreover, this section of people is more prone to others' behavioural norms and they think that buying PLs may result in considering the individual as 'cheap' (Dick et al., 1995). Hoch and Banerji (1993) found that right quality products and maintaining consistency in quality are more important than price in establishing PL products' market share. Findings from Richardson et al. (1996) also support the same results.

PL products are primarily subjected to two types of perceived risk: a) Product associated risk (functional and financial) and b) risk linked with the individual (Psychosocial) (Semeijn et al., 2004; Gómez \& Rubio, 2010). Batra and Sinha (2000) term functional and financial risk as the risks associated with the product's actual performance and the occurrence of quality variance occurring within a product category. Social risk is more psychological, as it occurs when customers believe that they may be evaluated negatively because of their brand choice (Gómez \& Rubio, 2010; Semeijn et al., 2004).

Mitchell and Greatorex (1993), Mitchell and McGoldrick (1996), and Semeijn et al. (2004) stated that a store's image serves as an indicator of PL brand quality and also acts as a risk reliever. However, Steenkamp and Dekimpe (1997, p. 927) express that "the power of a store brand, even for a powerful retailer, varies dramatically across product categories". The retail market has been facing fierce competition, and companies struggle to differentiate themselves in the marketplace. In this context, store image is one of the most important distinctive features that substantially benefit retailers (Konuk, 2018).

Quality variance within a category can lead to a phenomenon where customers evaluate PL products negatively. So when the quality variance is high within a category, consumers prefer buying NB products over PLs to reduce financial risk. This risk cannot be relieved by any other 
store image factors (Semeijn et al., 2004). The concept of store image was first introduced by Martineau (1958) in explaining how a consumer pictures a store in their mind based on different attributes such as the layout of the store, services offered, quality and collection of products, and internal environment. (Grewal et al., 1998; Anselmsson et al., 2007; Porral \& Lang, 2015). It is also expressed as the overall impression created in consumers' minds based on the store's intrinsic and extrinsic characteristics (Devlin et al., 2003; Wu et al., 2011).

\begin{tabular}{|c|c|c|c|}
\hline \multirow{9}{*}{ Price Consciousness } & Baltas (1997) & \multirow{8}{*}{ Innovation } & Baltas (1997) \\
\hline & Burton et al. (1998) & & Ailawadi et al. (2001) \\
\hline & Sinha \& Batra (1999) & & Jin \& Gu Suh (2005) \\
\hline & Batra \&Sinha (2000) & & Jin \& Gu Suh (2005) \\
\hline & Ailawadi et al. (2001) & & Martos \& González (2009) \\
\hline & Jin \& Gu Suh (2005) & & Martínez \& Montaner (2008) \\
\hline & Martínez \& Montaner (2008) & & Gómez \& Rubio (2010) \\
\hline & Martos \& González (2009) & & Fan et al. (2012) \\
\hline & Gómez \& Rubio (2010) & \multirow{5}{*}{ Impulsiveness } & Burton et al. (1998) \\
\hline \multirow{7}{*}{ Value Consciousness } & Burton et al. (1998) & & Ailawadi et al. (2001) \\
\hline & Garretson et al. (2002) & & Martinez \& Montaner (2008) \\
\hline & Jin \& Gu Suh (2005) & & Manzur et al. (2011) \\
\hline & Kara et al. (2009) & & Fan et al. (2012) \\
\hline & Gómez \& Rubio (2010) & \multirow{2}{*}{ Variety seeking } & Baltas (1997) \\
\hline & Manzur et al (2011) & & Ailawadi et al. (2001) \\
\hline & Diallo et al. (2013) & \multirow{4}{*}{ PL Familiarity } & Baltas (1997) \\
\hline \multirow{5}{*}{ Perceived Risk } & Sinha \& Batra (1999) & & Caplliure et al. (2010) \\
\hline & Batra \& Sinha (2000) & & Gendel \& Levy (2013) \\
\hline & Semeijn et al. (2003) & & Dursun et al. (2011) \\
\hline & Gómez \& Rubio (2010) & & \\
\hline & Dursun et al. (2011) & & \\
\hline \multirow{5}{*}{ Smart shopping } & Baltas (1997) & & \\
\hline & Burton et al (1998) & & \\
\hline & Garretson et al., (2002) & & \\
\hline & Liu \& Wang (2008) & & \\
\hline & Manzur et al., (2011) & & \\
\hline
\end{tabular}

Table 2.1: Empirical research on Consumer PLs for 1996 - 2017. Source: (Suárez et al., 2017). 


\subsection{Online Private Labels: Previous Research}

Despite growing research on e-commerce and online consumer behaviour, there is a lack of scholarly attention towards e-tailer owned (no physical brick-and-mortar stores) store brands. To the best of our knowledge, no previous researchers have coined a definition for an e-tailer PL (ePL). Therefore, I am proposing the following definition for this study: brands that are created by and for the e-tailer and are sold exclusively on e-tailer owned websites are called ePLs.

Arce-Urriza and Cebollada (2012) performed an empirical analysis to study the competition between PLs and NBs across online and offline channels using one year's real purchase data from a grocery chain (in Spain) relating to 2,742 households. Around 6.46 percent of products offered in the chain are PLs. They have assessed the competitive position of both the brands in thirty-six product categories covering 183 brands (which are frequently-purchased grocery items) using market share (MS), customer loyalty (CL), and conquesting power (CP) as a measuring criterion. Product categories are selected based on the conditions that the PL must be present and account for a substantial amount of sales in the category. It should also account for a significant proportion of sales both offline and online. Authors used modified Colombo and Morrison's (1989) model to study loyalty and conquesting power. This model is based on the brand-switching matrix and uses components representing the number of shoppers switching from one brand to another over two succeeding purchase instances. They've developed a switching matrix for each category and channel, totalling 72 switching matrices with the available data. Each PL is compared with an (RB) reference brand (it combines all NBs in a category into one unique measure) and (NBL) national brand leader (it is the NB with the highest market share in the category).

Their investigation results indicated that the competitive position of PLs in terms of MS, CL, and $\mathrm{CP}$ is better online than offline. At the same time, RB and NBL seem to improve their competitive position online only in terms of CL. Findings also suggested that online channel has an optimistic effect on loyalty over all brands. PLs attained both greater conquesting power and loyalty online whereas, RB and NBL lost a little of conquesting power but gained substantially higher customer-loyalty scores. Additionally, they've also found that online PL loyalty gains are not the same across categories. 
Parsons et al. (2012) used a website that is a facsimile of an actual website to study the Countryof-origin (COO) perceptions on PLs and store proprietorship of online grocery shoppers. This research also seeks to address the context of binational stores: "brands carrying foreign-owned store's brand name but are locally made or brands carrying locally owned store's brand name but are foreign made." They've conducted three studies with the same sample of subjects where the subjects were asked to shop for a basket of products using the website created for the experiment. To make the study happen in a realistic environment, they've used two major grocery chains belonging to Progressive Enterprises Ltd, which operates online shopping websites in New Zealand. But the only difference was that the subjects could not actually complete the transaction. Their first study observed the COO effect on the value, perceived quality, and risk attached to NBs vs. PLs. Results from study one stated that: a). COO had the major impact on perceived quality ratings with merchandise being preferred if it is locally manufactured, b). local brands were found to be considered of better value than foreign brands and c). locally sourced products are perceived as less risky than foreign-sourced in terms of quality. Study two is an extension of study one where a third element, local/foreign ownership of the store, is added, and the results indicated that: a). the perceived quality is affected by the cumulative factors of both store and brand. b). locally owned stores are seen to sell better value goods and c). Locally owned stores are perceived to sell lower-risk goods. In study three, they've studied cultural proximity, and the results concluded that the consumers prefer products from a culturally close country.

Overall, this study concludes that it is advantageous to PLs if they are locally sourced, and it is better if the store is also locally owned. A brand is preferred if it is from a culturally close country to the seller's country.

Dawes and Nenycz-Thiel (2014), in their study, explored four crucial topics:

a. an online store's ability to attract other retailer's customers, instead of their own physical store shoppers,

b. does online shopping leads to more retailer cross-purchasing by shoppers.

c. how does brand loyalty differ in-store and online?

d. how do PLs perform online compared to in-store?

To investigate the proportions mentioned above, they've used consumer panel data from Kantar, including in-store and online purchases of more than 15,000 households from the UK 
market. They've analysed data for three leading UK retailers with a substantial presence online and in-store across ten categories. The authors used Ehrenberg's (2000) model to analyse consumer cross-purchasing behaviour for online and in-store modes and share of category requirements (SCR) metric for examining brand loyalty. Results indicated a high inclination of online buyers at one retailer to shop online at other stores as well; however, at the same time, it was also found that the brands exhibit higher brand loyalty online compared to physical stores. And finally, PLs, specifically medium and higher quality PLs, enjoy more market share online than in-store.

Arce-Urriza and Cebollada (2018) performed an empirical analysis using purchase data from a grocery retailer operating both online and in-store to analyse online competition between PLs and NBs or Reference brand (RB), a global indicator of NBs. They've used intrinsic loyalty (IL) and conquesting power (CP) as the measures to compute competition across 36 product categories. With these two measurements, four competitive positions were generated: giants, misers, fighters, and artisans. They've also examined if the competitive position of PLs against NBs varies across channels and product categories. Authors have used Colombo and Morrison (1989) model to make IL and CP paradigms. Results revealed that moving to the online setting can improve the competitive position of PLs and the relative IL of the PL improves significantly online. However, this improvement is not the same across all categories. Also, PLs relative CP is higher when marketed online in non-sensory categories.

Kumar and Chandra (2020) empirically examined consumer purchase intention towards Private Label brands of Virtual retailers (PLBV) in a developing nation like India. They've developed a purchase intention framework by incorporating online store image, consumers' technology acceptance, perceived risk, value and price consciousness, and other variables. They used confirmatory factor analysis and structural equation modelling to validate the framework. A purposive sampling technique was used to identify respondents, and they were screened based on the criteria that they have purchased PLBV at least once in the last six months. The current investigation results explain an interesting outcome that price consciousness does not impact customers' attitudes towards PLBV individually. Yet it substantially escalates purchase intention when interacting as a group with other factors. Research outcomes also suggested that buyers of PLBV are more value-conscious than price. The more the perceived risk is, the less the chances of purchasing store brands of virtual retailers are less, and the store's image is 
directly proportional to consumers' attitude and purchase intention towards virtual retailers' store brands.

Li et al. (2018) used a game-theoretic model to incorporate the organisations' channel and brand strategies and investigated the strategic relation between an NB manufacturer and a retailer in introducing a store brand and a direct online channel.

\begin{tabular}{|c|c|c|c|}
\hline Author/Date & Research Topic & Analysis/Results & Industry \\
\hline $\begin{array}{l}\text { Arce-Urriza } \\
\text { and Cebollada } \\
\qquad(\mathbf{2 0 1 2})\end{array}$ & $\begin{array}{l}\text { Competition between } \\
\text { store brands and national } \\
\text { brands across offline and } \\
\text { online channels. }\end{array}$ & $\begin{array}{l}\text { Both PL and NB increase their loyalty online } \\
\text { when compared to offline, whereas only PL's are } \\
\text { growing market share and conquesting power } \\
\text { online. }\end{array}$ & $\begin{array}{l}\text { Retail - } \\
\text { Grocery }\end{array}$ \\
\hline $\begin{array}{l}\text { Parsons, } \\
\text { Ballantine \& } \\
\text { Wilkinson } \\
\quad \text { (2012) }\end{array}$ & $\begin{array}{l}\text { Country-of-origin (COO) } \\
\text { perceptions of private } \\
\text { labels and store } \\
\text { proprietorship. }\end{array}$ & $\begin{array}{l}\text { Advantageous for PL's if locally sourced and } \\
\text { better if the store is owned locally. People prefer } \\
\text { brands that are sourced from countries that are } \\
\text { culturally close to the seller's country. }\end{array}$ & $\begin{array}{l}\text { Retail - } \\
\text { Grocery }\end{array}$ \\
\hline $\begin{array}{l}\text { Dawes and } \\
\text { Nenycz-Thiel } \\
\text { (2014) }\end{array}$ & $\begin{array}{l}\text { Comparing retailer } \\
\text { purchase patterns and } \\
\text { brand metrics for in-store } \\
\text { and online. }\end{array}$ & $\begin{array}{l}\text { Store brands enjoy a little bit higher market share } \\
\text { online than in-store. }\end{array}$ & $\begin{array}{l}\text { Retail - } \\
\text { Grocery }\end{array}$ \\
\hline $\begin{array}{c}\text { Arce-Urriza } \\
\text { and Cebollada } \\
\text { (2018) }\end{array}$ & $\begin{array}{l}\text { Assessing the success of } \\
\text { PL's online (analysing } \\
\text { online competition } \\
\text { between PL's and } \\
\text { National brands). }\end{array}$ & $\begin{array}{l}\text { Store brands significantly improve their } \\
\text { competitive position online. }\end{array}$ & $\begin{array}{l}\text { Retail - } \\
\text { Grocery }\end{array}$ \\
\hline $\begin{array}{c}\text { Kumar and } \\
\text { Chandra (2020) }\end{array}$ & $\begin{array}{l}\text { Analysing consumer } \\
\text { purchase intention } \\
\text { towards PL brands of } \\
\text { virtual retailers. }\end{array}$ & $\begin{array}{l}\text { Store image has a positive effect on consumers' } \\
\text { attitude and purchase intention towards virtual } \\
\text { retailers, and the chances of purchasing store } \\
\text { brands are less if the perceived risk is high. }\end{array}$ & Unspecified. \\
\hline This research & $\begin{array}{l}\text { Exploring the factors } \\
\text { affecting the purchase- } \\
\text { likelihood of e-tailers PLs }\end{array}$ & $\begin{array}{l}\text { Consumer online rating has shown positive effect } \\
\text { on consumer purchase likelihood towards e-tailer } \\
\text { PLs. e-tailer reputation effect is found only in } \\
\text { future purchase intention whereas, product } \\
\text { manufacturing favourability effect is seen in only } \\
\text { in actual purchase. }\end{array}$ & Electronics \\
\hline
\end{tabular}

Table 2.2: Summary of research on online PLs.

\subsection{Research Gap}

Arce-Urriza and Cebollada (2012) pointed that the outright rise of the battle between NBs and PLs occurred because of the growing importance of PLs in current marketplaces. Since the pioneering study by Myers (1967), scholarly research on PLs has been growing remarkably, especially in the last twenty years (Gómez et al., 2017). But, most of the previous research was 
towards understanding different aspects of PLs in physical store environments. As per Altintas et al. (2010), PL research can be divided into three categories: a) consumer-based and related studies, b) NBs and PL comparisons, and c) manufacturer-related studies. Different consumerbased research areas examined factors such as socio-demographics, psychographics, lifestyle, behavioural, price and value consciousness, risk factors and, impulsiveness. (Saurez et al., 2017; Martínez \& Montaner, 2008). However, Eroglu et al. (2000) stated that that the classifications of physical store atmospheric qualities cannot be totally applied to the online environment, yet only a handful of researchers involved online PLs in their studies.

Authors like Arce-Urriza and Cebollada (2012) and Dawes and Nenycz-Thiel (2014) studied the performance of PLs and NBs in online and offline marketplaces. PLs used in this study are from a retailer with a presence in both physical stores and online stores. This study only compares NBs and PLs owned by a retailer, it does not investigate e-tailer PLs. There are higher chances that consumers buying from a retailer website might have visited the physical store. Those visits can have an impact on consumer buying behaviour. Many previous researchers like (Martineau, 1958; Anselmsson et al., 2007; Porral \& Lang, 2015) studied the importance and effects of store image. However, the effects of store image might be different for e-tailer PLs.

Research from Parsons et al. (2012, p. 596) investigated country-of-origin effects on online PL purchases. They tried to understand whether consumers favour brands from a culturally relatable nation rather than those from a culturally distant nation. However, they have studied this effect on PLs that are sold in-store and online marketplaces by the same retailer. All the above studies have used PLs from the FMCG sector and PLs that are selling in both online and offline stores for their investigations. But, none of these studies have researched the factors affecting the consumer purchase intention towards e-tailer PLs.

The growth of e-commerce has led to the emergence of many global e-tailer brands like Amazon, Flipkart, etc. To the best of my knowledge, research from Kumar and Chandra (2020) is the only study investigating the PLs of virtual retailers (e-tailers). They have developed a framework to understand the effects of different aspects such as online store image, perceived risk, consumer technology acceptance and other variables. But their study is more of a generalised PL study than a study on a specific industry. Hence, there is a need to study different aspects of e-tailer PLs across different industries. Electronics and media are one of the most mature segments in e-commerce with total global revenue of 419.0 billion USD in 
2019 (Rotar, 2020). But there has been no academic research on the online PLs in the electronics category. Considering the importance of the electronics category to e-tailer brands and the need for understanding the effects of extrinsic cues like the country effect, I try to initiate an investigation on e-tailer PLs in the electronic category through this study.

This study's primary interests are to understand: the effects of a) e-tailers image, b) product manufacturing country e-tailer PLs, and c) products consumer online ratings on the purchase likelihood of PLs.

\section{Chapter 3: Conceptual Foundations and Framework}

\subsection{Introduction}

This chapter discusses the developed hypotheses and the theoretical framework for study 1 and study 2 based on the literature review. It is organised into five sections. It starts with reviewing the stimulus-organism-response model and cue utilisation theory. It is followed by the justification for the proposed hypotheses. And the final section describes the mediation effects of emotional states and establishes a hypothesis for the mediated effect.

\subsection{Stimulus-Organism-Response Theory}

Donovan and Rossiter (1982) were the ones who first used the SOR model to develop a theoretical framework to study store atmosphere effects. Most of the existing research that has used the SOR framework is to study physical store atmospheres (Liu et al., 2020). The popularity of the Internet and the adoption of e-commerce has extended the SOR framework into online store environments to understand customers' behaviour (Eroglu et al., 2001; Koo \& Ju, 2010; Kim \& Lennon, 2013; Mosteller et al., 2014). Liu et al. (2020) also stated that it is essential to understand the influence of online store atmosphere and other environmental stimuli on online shoppers' behaviour. Previous researchers have chosen this framework to study different aspects of the online store environment such as the effects of shoppers' perceived fluency of the verbal online information on the choice (Mosteller et al., 2014), and the influence of reputation and website quality on online consumers' emotions and purchase intention (Kim \& Lennon, 2013). Chen and Yao (2018) adopted this model to understand the drivers that are influencing impulse buying behaviours in a mobile auction. Some authors like Peng and Kim (2014) and Kühn and Petzer (2018) have used this structure to understand the shopper's online behaviours and purchase intentions. Existing research on shopping contexts 
using this model found that the shoppers' behavioural intent is based on how they process the environmental stimuli (Eroglu et al., 2003; Mosteller et al., 2014).

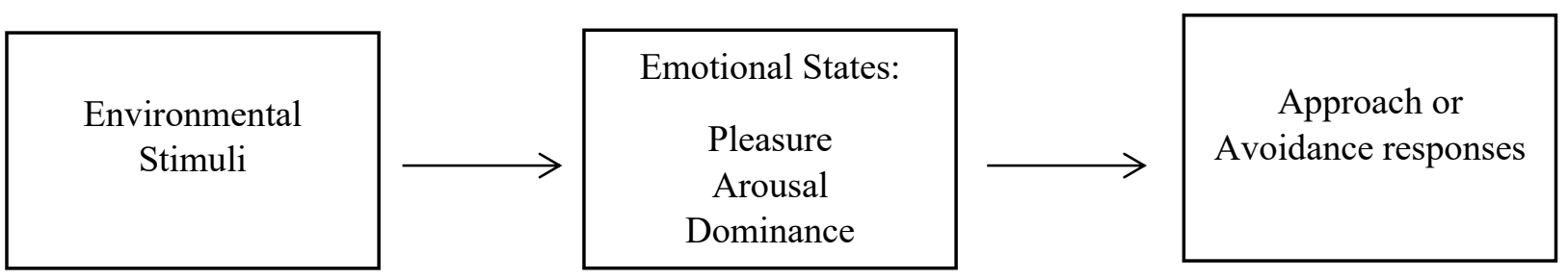

Figure 1: Mehrabian-Russell S-O-R model.

In this study, I have used the stimulus-organism-response model to study the stimulus effects of e-tailers brand reputation, product manufacturer's country (PMC), and online consumer ratings (of the e-tailer owned products) on the purchase likelihood and actual purchase of PL products.

\subsection{Cue utilization theory}

Cue utilization theory explains how consumers consciously evaluate the quality and characteristics of a product using a range of information cues (Verlegh \& Steenkamp, 1999; Woodside, 2012; Herz \& Diamantopoulos, 2013; Garrett et al., 2017). Olson and Jacoby (1972) classified cues as a) Intrinsic and b) Extrinsic. (Mishra et al., 2020).

a. Intrinsic Cues: Information cues that are the primary characteristics of a product affecting its appearance and performance, such as ingredients, texture, taste, etc., (Woodside, 2012; Herz \& Diamantopoulos, 2013; Garrett et al., 2017).

b. Extrinsic cues: Elements that are peripherally related to the product and do not affect the product's performance or appearance. e.g., price, brand name, store name, etc., (Woodside, 2012; Herz \& Diamantopoulos, 2013; Garrett et al., 2017).

Even though consumers can make reliable judgements on product quality based on intrinsic cues, they frequently depend on extrinsic cues while making product impressions as information on extrinsic cues is more easily obtained than intrinsic cues (Olson \& Jacoby, 1972; Li et al., 2000). Richardson et al. (1994) also stated that extrinsic cues influence consumer perceptions of product quality more than intrinsic cues for store-brand grocery items. This theory believes that extrinsic information cues will dominate a consumer's product evaluation process and purchase intention when the consumer has no prior experience or information (Verlegh \& Steenkamp, 1999; Herz \& Diamantopoulos, 2013). When data on 
intrinsic cues are not available or difficult to analyse, consumers can use extrinsic cues as a shortcut for product assessment and purchase decisions (Garrett \& Lee, 2017).

\section{4. e-Tailer Reputation and Country of Manufacture Favourability \\ 3.4.1 e-Tailer reputation}

Traditionally, a store's image is a combination of dimensions that consumers perceive as a store. These dimensions are both independent and interdependent in consumers' memory learned from current and earlier experiences, which combines into an overall impression of the store (Hartman \& Spiro, 2005). For an e-tailer, a virtual marketplace or a website replaces the physical store. It has long been established that retailers or a group of retailers create an image in consumers' minds. In retailer branding, the store plays an important and unique role as it is where the shopper experiences the retailer (Burt \& Davies, 2010). Many previous authors stated, 'Store is the retail product' (Porter \& Claycomb, 1997; Floor, 2006).

As mentioned by Woodside (2012) and Herz and Diamantopoulos (2013), the brand name of a product is an extrinsic cue that customers consciously use to evaluate the quality of the product. Consumers buying choices can be affected by a retailer's reputation as most buyers are more likely to buy from a reputable retailer than from an unknown retailer (Akaah \& Korgaonkar, 1988; Tan, 1999). Kotha et al. (2001) also stated that shoppers are more likely to purchase from an online retailer with a superior online reputation. When shoppers lack information on product or service providers and product intrinsic cues are unavailable, they rely more on extrinsic cues (Zeithaml, 1988; Selnes, 1993). So, in an online retail environment, when information on some intrinsic cues (e.g., ingredients, taste, and texture) is not available, then shoppers may rely on extrinsic cues (e.g., firm reputation, $\mathrm{COO}$, and brand) to assess product or service providers (Yoon et al., 1993). Online retailer reputation may well act as an external source of information and significantly influence consumer responses and future behaviours, and website quality (Jin et al., 2008; Lwin \& Williams, 2006). Hence, a good reputation is an asset to the firm that can enhance shoppers' expectations about its offerings (Schmalensee, 1978; Shapiro, 1983) and minimize uncertainties about the product or service performance (Yoon et al., 1993). Through their study, Kim and Lennon (2013) identified that it is vital for businesses to develop a highquality website and maintain a good reputation among shoppers. In line with the above discussions, I hypothesise that:

Hla: The more favorable e-tailer reputation is, the greater is PL purchase intention. 
H1b: The more favorable is e-tailer reputation, the greater is the likelihood of actual PL purchase.

\subsubsection{Country of Manufacture Favourability}

Since the 1960s, there have been studies on the impact of a manufacturer's country or Countryof-origin (COO) effects on product evaluation and purchase intention (Rezvani et al., 2012). Saridakis and Baltas (2016) expressed that one of the long-standing interests of international marketing is the effect of a product's $\mathrm{COO}$ on consumer purchase behaviour. Researchers who have studied the influence of COO effects on consumer behaviour (Lee et al., 2005) found that $\mathrm{COO}$ is one of the factors that is significantly influencing international marketing (Rezvani et al., 2012).

Dhar and Simonson (2003) express that 'consumer choice' is one of the most common tasks used to assess buyer preferences in marketing research studies. Consumers are fed continuously with different types of information through packaging, advertising, branding, etc., through which consumers make preferences about a product (Verlegh \& Steenkamp, 1999). Previous studies (Hong \& Wyer, 1989; Verlegh \& Steenkamp, 1999) have shown that a product's origin can influence consumers' judgement. Several reviews on COO effects have also concluded that consumers use $\mathrm{COO}$ as an instrument to evaluate the quality of products (Liefeld, 1993; Peterson \& Jolibert, 1995; Chuang \& Yen, 2007). COO of a product also affects consumers' perceptions while evaluating the risks involved in purchasing the product and the likelihood of the purchase (Peterson \& Jolibert, 1995; Verlegh \& Steenkamp, 1999; Saridakis \& Baltas, 2016).

Olson (1972) expressed that COO is considered an extrinsic cue as it can be manipulated without making any physical product changes. Hence, it is not different from other extrinsic cues like brand name, retailer reputation, price, etc., which act as "signals" for product quality (Steenkamp, 1990; Dawar \& Parker, 1994; Verlegh et al., 1999). Herz and Diamantopoulos (2017) also expressed that the COO effect functions as an extrinsic informational cue while consumers make product evaluations. Following the past identifications that country associations can affect product or brand assessments, a vast body of literature has established substantiating evidence that there is a significant relationship between consumers' views of a country (i.e. country image) and their assessments of products connected with that country (Verlegh \& Steenkamp, 1999; Magnusson et al., 2018). Country stereotypes reflect an 
individual's opinions about a country's features, established through exposure to information about countries and socialization processes (Diamantopoulos et al., 2017).

A product's country associations can substantially influence the consumers' judgments of product quality (Klein et al., 1998; Yelkur et al., 2006). Rezvani et al. (2012) also stated that manufacturing countries could affect shoppers' intention either positively or negatively depending on their country's perception. Individuals generally hold stereotypical notions about people and products of other countries, and this country stereotyping impacts real product evaluations at all times (Tse \& Gorn, 1993). So merchandise from developed countries is evaluated more positively than products from less developed countries (Gaedeke, 1973; Yelkur et al., 2006). If buyers have favourable associations with the country related to the product, that relationship will positively influence how the product information is processed, resulting in more positive product assessments (Chen et al., 2014). Therefore, it is reasonable to hypothesise that:

H2a: The more favourable the country of manufacture is, the greater is PL purchase intention.

H2b: The more favourable the country of manufacture is, the greater is the likelihood of actual PL purchase.

\subsubsection{Interaction Effects}

A common suggestion from international marketing literature for brand positioning strategy is that brands should highlight country associations only if they are from a country with a strong image: whereas, brands associated with a weak country image should avoid country association (e.g. Kumar \& Steenkamp, 2013; Herz \& Diamantopoulos, 2017; Magnusson et al., 2018). A large body of studies tried to understand how country cues can provide value to a brand, affect risk perceptions, become an indicator of quality, and can influence shoppers' brand or product picks (Maheswaran \& Chen, 2009; Magnusson \& Westjohn, 2011; Diamantopoulos et al., 2017). Pappu et al. (2007, p. 728) argued that in a given market, shoppers' perceptions of a country and product opinions from that country could affect user-based brand equity, i.e., "a country image can have a significant impact on the dimensions of brand equity." Magnusson et al. (2018, p. 329) also stated that "country personality characteristics reaching beyond typical COO favourability can significantly influence brand evaluations," and consumers form mental schemas about countries based on their associations with that country which will influence brand assessments. Through their research, Parsons et al. (2012) identified that consumers 
prefer PLs from a culturally close country to their country. In line with the above discussions, it is reasonable to hypothesize that:

H3a: The more favourable the country of manufacture is, the greater is the effect of e-tailer reputation on PL purchase intention.

H3b: The more favourable the country of manufacture is, the greater is the effect of e-tailer reputation on actual PL purchase.

The hypotheses (H1, H2, and H3) are depicted in Figure 2.

Figure 2. Conceptual Framework for Study 1

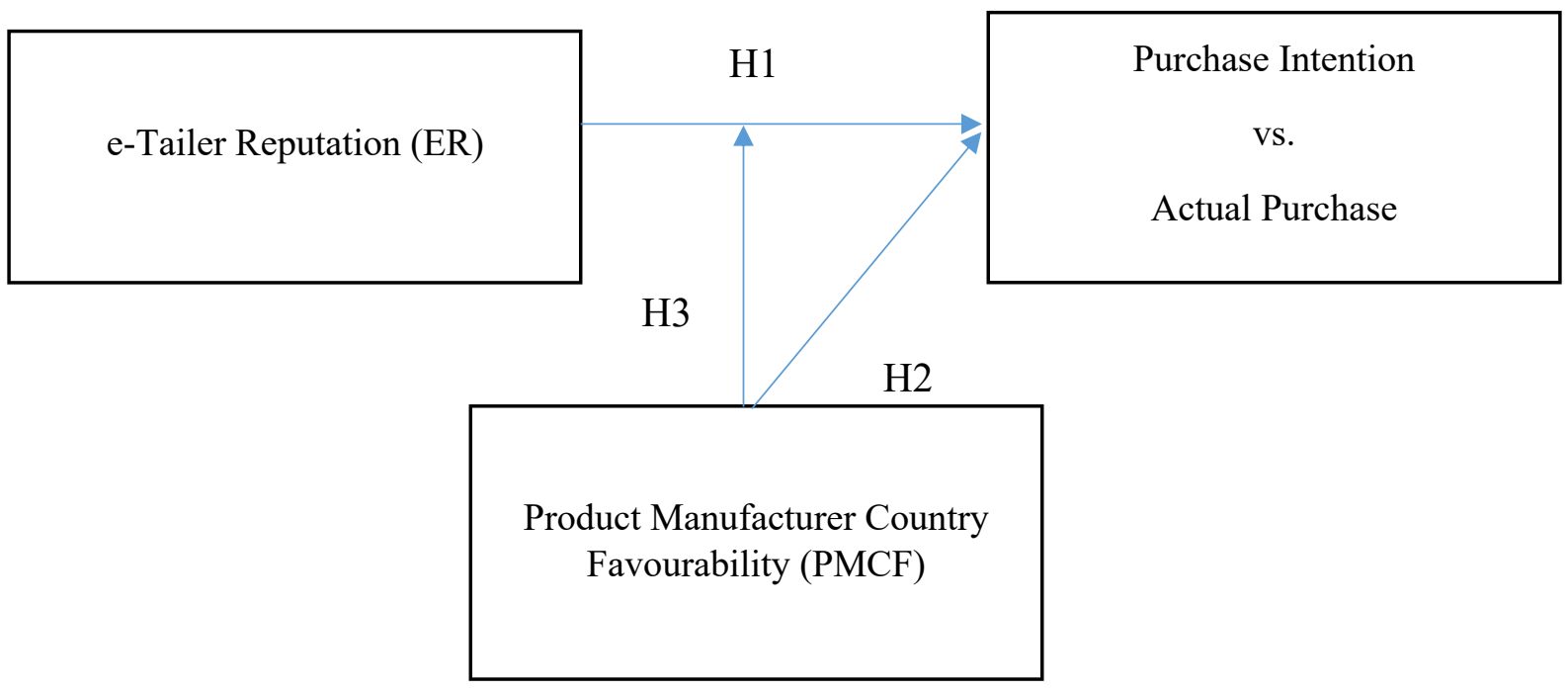

\subsection{Online Consumer Ratings: PL Rating vs. Competitor Brands' Rating}

\subsubsection{PL Rating}

An online review system is a process of gathering and displaying customer ratings and reviews to facilitate buyers in purchase decisions (Ren \& Nickerson, 2019). These customer ratings are defined as a combination of product performance and customer expectations (Fornell, 1992; Fornell et al., 1996), whereas Engler et al. (2015) argued that these ratings represent consumer satisfaction rather than the performance of the product. Along with the growth of e-commerce, online product ratings and reviews have become a significant source of information for retailers and customers (Mudambi \& Schuff, 2010). Reviews and ratings submitted by online store users provide product information to potential customers, reducing uncertainty about the product (Chen \& Xie, 2008). Additionally, e-tailers and manufacturers' reliance on customer feedback 
to improve their marketing strategy and create additional revenue streams is on an increasing note (Chen \& Xie, 2008; Cui et al., 2012; Mudambi \& Schuff, 2010).

Organisations believe that online consumer ratings affect consumers' purchase decisions (Zhu $\&$ Zhang, 2010). Many past studies have proved that customer ratings affect sales in various contexts (Chevalier \& Mayzlin, 2006; Park et al., 2007; Lin et al., 2011). Online reviews and ratings (or) User-generated content (UGC) play a crucial role in influencing both consumers' demand and marketing strategies (in the hotel industry) (Jang \& Moutinho, 2019). It is also termed as online consumer reviews (OCR) in some studies (e.g. Jang et al., 2019).

Previous research on online product ratings studied this topic from different perspectives and can be classified depending on whether they investigate the antecedents or their outcomes. Antecedent studies researched the effects of online product ratings on consumers' purchasing decisions (Park et al., 2007; Mauri \& Minazzi, 2013). The second category examined the factors influencing online customer ratings (Engler et al., 2015).

Many studies have expressed that the volume of UGC strengthens consumers' confidence in a product, as it can indicate a product's credibility and acceptance. Boosting consumers' confidence in the product can lead to a greater inclination to pay for the product (Brynjolfsson \& Smith, 2000; Jang \& Moutinho, 2019). Research has found that buyers online purchase decisions can be influenced by both valences (Chevalier \& Mayzlin, 2006; Dellarocas et al., 2007; Ye et al., 2011) and volume of reviews (Duan et al., 2008; Hu \& Liu, 2004; Pang et al., 2002). Valence is an expression of positive or negative sentiment and can be gauged by the star rating (Ye et al., 2011; Ren \& Nickerson, 2018). Volume is the total number of online reviews submitted to online review systems for a particular product (Ren \& Nickerson, 2018). Some reports have explained the effects of positive and negative reviews in terms of negativity bias; that is, shoppers tend to keep away from goods with negative remarks more than they are attracted to products with positive comments (Park \& Lee, 2009; Ren \& Nickerson, 2018). Another study has found that both online review valence and volume were important in estimating movie sales (Dellarocas et al., 2007).

The importance of word of mouth on business has been widely discussed and researched worldwide. UGC serves as new word of mouth for online providers' products and services (Ye et al., 2011). Despite the growing importance of online UGC, some studies have stated that traditional WOM (word of mouth) is considered more credible than online UGC as it lacks 
source cues (Dellarocas, 2003; Smith et al., 2005). Research conducted by Dickinger and Mazanec (2008) states that the most critical factors influencing online hotel bookings are friends and online UGC references. Online WOM can help managers in brand-building exercises, quality assurance, and product development (Dellarocas, 2003).

Ghose and Ipeirotis's (2006) research on the effect of UGC on product sales for different consumer products found that subjectivity and polarity of the ratings can have a substantial impact on online sales of certain products. They have used cognitive load theory to explain their outcomes. They have also stated that certain types of online reviews trim down the buyer's cognitive load, which can lead to generating higher sales. Therefore, we hypothesize that:

H4a: The greater PL online consumer rating is, the greater is PL purchase intention.

H4b: The greater PL online consumer rating is, the greater is the likelihood of actual PL purchase.

\subsubsection{Interaction Effects}

The online reputation of a product or service is established when users of that particular product or service share their opinions and experiences through a process called online social communication (Estárico et al., 2012). Varini and Sirsi (2012) and Anderson (2012) also stated that a firm's online reputation is formed by quantitative and qualitative facts and figures that can be accessed online. Consumers make opinions about brands depending on their positive or negative experiences with that particular brand and share their views with other potential consumers through a process called WOM (Richins, 1983; Amblee \& Bui, 2007). Advancements in technology have allowed the process of exchanging experiences, comments, and points of view about a product, service, or brand through different online platforms. In this context, a new term, e-WOM, has emerged where users influence other potential users through their online ratings and views (Litvin et al., 2008; Rodríguez-Díaz et al., 2018). Previous studies have indicated that eWOM can strongly influence online brand trust (Amblee \& Bui, 2007). Hong-Youl Ha (2004) assumed that positive WOM among satisfied members helps users to develop favourable brand trust in e-commerce. Therefore, based on the above discussions, we hypothesize that:

H5a: The greater PL online consumer rating is, the greater is the effect of e-tailer reputation on PL purchase intention. 
H5b: The greater PL online consumer rating is, the greater is the effect of e-tailer reputation on actual PL purchase.

\subsubsection{Conditional Effects: Competitor Brands' Online Ratings}

As mentioned above, e-WOM can significantly impact the brand trust (or) e-tailer reputation, boosting consumers' confidence in the product and leading to higher sales. It is also essential to understand the effects of other brands' (NB) ratings (positive or negative) on the PL products' purchase likelihood. In their study, Alberti and DeFanti (2019) compared the online rating of NB product's with PL brand online ratings to understand Hoch and Banerji's quality consistency factor (1993). Similarly, Arce-Urriza and Cebollada (2012) also used data that consist of NB and PL products so it is useful to compare competitive strengths of both brands in online and offline environments. In line with the above studies, I am studying how other competitor brands' ratings will influence the purchase intention of PL products.

Multiple scenarios may arise depending on the performance of PLs and their competing brands. To understand online rating effects in all possible situations, I have created the following scenarios:

a. When competing brands' online consumer rating is high: In this scenario, the competing brands' ratings are kept high and the consumer purchase behaviour towards PLs is investigated Comparisons will be made with competing brands' high ratings $\mathbf{x}$ PLs low rating and competing brands' high ratings $\mathbf{x}$ PLs high rating.

b. When competing brands' online consumer rating is low: In this scenario, the competing brands' ratings are kept low and the consumer purchase behaviour towards PLs is examined. Comparison will be made with competing brands' low rating $\mathbf{x}$ PLs low rating and competing brands' high ratings $\mathbf{x}$ PLs high rating.

Doing this makes it possible to understand how consumers' purchase behaviour changes towards PL in line with competing brands' performance.

H6: Competitor brands' online consumer rating will attenuate the effects reflected in Hypotheses H1 (a, b), H4 (a, b), and H5 (a, b). 
Figure 3. Conceptual Framework for Study 2

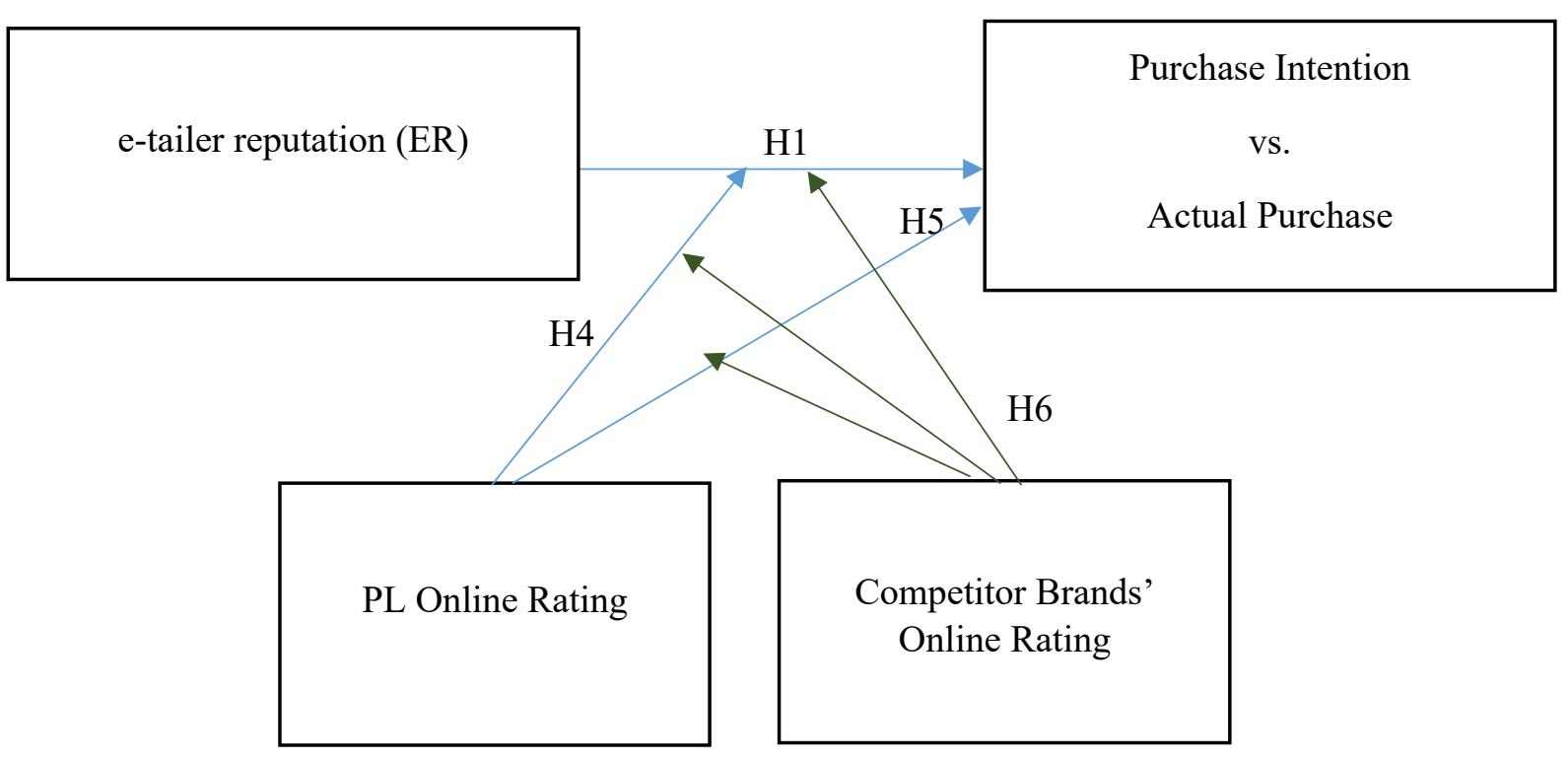

\subsection{Mediating Effects of Emotional States}

Mehrabian and Russell (1974) have proposed the stimulus-organism-response (S-O-R) model in the early days of the environmental psychology field. This framework consists of three components that are sequential in nature: a stimulus, an organism, and a response (Mehrabian \& Russell, 1974). It explains how observed stimuli in an environment (stimulus) draw out cognitive or affective states in an individual (organism), which brings out a behavioural response from that individual (response) (Donovan \& Rossiter, 1982; Mehrabian \& Russell, 1974). The rise of e-commerce has extended the S-O-R framework into online store environments to understand the customers' behaviour (Eroglu et al., 2001; Koo \& Ju, 2010; Kim \& Lennon, 2013; Mosteller et al., 2014).

In the classical S-O-R model, a stimulus is defined as the cues that affect the individual's internal states (Eroglu et al., 2001). According to Bagozzi (1986), the stimuli are external to the person and consist of marketing mix variables and other environmental inputs. Eroglu et al. (2001) were the first to study online consumer behaviours using environmental psychology. Their findings illustrated that the consumers' emotional states are affected by online stores' ambiance and stimulus factors eliciting consumer behaviours. Manganari et al. (2009) also 
showed that consumers' assessments or experiences of online stores induce emotions and affect their actions. In this study, e-tailers' reputation, product manufacturing country, and online product ratings are considered as stimulus factors.

Organism refers to the internal processes and structures consisting of perceptual, physiological, feeling, and thinking activities arbitrating between stimuli external to the person and the final response emanated (Bagozzi 1986). The response represents the consumers' reaction in the form of either approach, denoting a favourable reaction (or) avoidance representing opposite behaviour (Mehrabian \& Russell 1974; Bitner, 1992; Eroglu et al., 2001).

Past studies have indicated that consumer's personal and emotional status can be influenced by external environmental factors (Chen \& Yao, 2018). Furthermore, various kinds of marketing stimuli within the consumption environment, along with environmental factors of online platforms, are all important aspects that can prompt buying behaviours (Campbell \& Diamond, 1990; Dawson \& Kim, 2009). Kim and Lennon (2013) stated that S-O-R framework can be used to: a) measure the influence of internal factors such as website characteristics and, b) test the effects of external environment stimulus on purchase intention (as cited in Kaur et al., 2017). Therefore, based on previous research, this study focuses on environmental factors and product features to explore the purchase likelihood of PLs.

The original S-O-R model proposed by Mehrabian and Russell (1974) states that three emotional states, pleasure, arousal, and dominance (PAD), mediate approach or avoidance behaviour in any environment. Many studies have removed the dominance dimension for theoretical reasons and lack empirical support (Donovan et al., 1994). In this study, I have also used the model presented by Donovan et al. (1994) without dominance.

H7: The effect of e-tailer reputation on private label product purchase likelihood is mediated by organism (e.g. pleasure, arousal) factors.

H8: The product manufacturer country's effect on a private label product purchase likelihood is mediated by organism (e.g. pleasure, arousal) factors.

H9: The effect of online consumer rating on a private label product purchase likelihood is mediated by organism (e.g. pleasure, arousal) factors. 


\section{Chapter 4: Research Overview and Method}

\subsection{Experimental Approach}

This research uses an experimental design because it is a widely used method and the only type of research method that can actually prove cause and effect. Thus, this is often referred to as causal research (Clow \& James 2014). In the experimental research method, independent variables are manipulated, and their effect on dependent variables is measured. Also, this method allows the researcher to regulate the research situation so that causal relationships among variables may be assessed. Using this design, events can be controlled in a research to the degree that may not be possible in a survey (Zikmund et al., 2017). This method is a collection of research designs to comprehend different causal processes through manipulation and controlled testing (MBA Skool Team, 2018). This method involves collecting quantitative data and performing statistical analysis to approve or reject a hypothesis (Formplus, 2020). Current research also requires some manipulations to independent variables to understand their effect on dependent variables. Hence, this method is better suited to this scenario.

\subsection{Identification of e-tailer brands}

In this research, the following e-tailer brands were selected: a) Amazon and b) DigiShack. Amazon represents a reputable brand, while DigiShack is an imaginary brand name created for this research. The process and rationale behind selecting these brands are discussed below.

The e-tailer brand Amazon was selected because, in the global ranking of online retail websites, Amazon is leading in terms of website traffic (Coppala, 2021) and has its services available in seventeen countries (Enberg, 2018). Amazon's global market share is approximately 14\% percent, and its share of retail in the United States is about 50\% (Sabanoglu, 2020). Amazon is selling its PLs in a wide range of categories using different brand names like Amazon Basics in the electronics category, Amazon Elements for health care, and Amazon Fresh in the grocery category, etc. Amazon is a well-known brand in the US, so its Amazon Basics products are easily recognizable while shopping online.

As Amazon is a US brand, a new brand name that sounds like a US name was chosen (DigiShack). To select DigiShack, I have first interviewed ten US residents to take inputs on names that can be a good fit for a new US-based e-tailer brand. Interviews were performed using Zoom and Skype platforms. Based on their inputs, I have created a list of five fictional names: Mom-n-pop online, Buyable, DigiShack, Make-believe-electronics, and Get-wired. Then I have created a questionnaire by including the names mentioned above. The 
questionnaire was distributed to some of the US residents. Respondents were asked to choose an apt name for a US-based online company that sells electronic-based products. Fifty percent of the respondents have chosen DigiShack, $40 \%$ chose Get-wired, and 10\% chose Makebelieve-electronics. Therefore, I selected DigiShack as a new brand name to be used in this research.

\subsection{Identification of product categories and competitive brands}

In this research, I focused on PLs from the electronic category because it is one of the highestselling categories online. Computer and consumer electronics category digital sales accounted for $49.5 \%$ in the United States as of May 2020 (eMarketer, 2020). For this study, I chose three product categories (an iPhone USB cable, a Bluetooth speaker, and a universal travel adapter) belonging to the electronics category. These categories have been selected because most of these products are:

a) Priced under 100 USD, and therefore customers do not have to go through a complex decision-making process

b) Used in day-to-day life, so after need recognition, consumers can move directly to evaluating alternatives stage by eliminating the information search stage (stage 2 of the buying process)

c) Consumers do not require any technical knowledge to purchase these products

d) All these products are offered by Amazon under its PL brand name "Amazon Basics."

Also, I have selected three competitive national brands. All competitive brands were selected from the Amazon.com website. These brands have similar product features to Amazon Basics.

- iPhone lightning cables - The competitive brands selected are as follows: Belkin, Anker, and Xcentz. All these brands are Apple MFI (Made for iPhone/iPad/iPod) certified. Both the brands Anker and Belkin iPhone cables are also available for sale on Apple's official website. Xcentz brand's iPhone cable has a 4.5 rating out of 5 on the Amazon website.

- Bluetooth speakers - The competitive brands selected are as follows: Anker, JBL, and Oontz. Anker brand's Bluetooth speaker size and shape look similar to the Amazon Basics speaker. JBL's speaker is listed as a best seller on the Amazon website, and Oontz speaker has a 4.5 rating out of 5 (more than 100,000 ratings) on the Amazon website. 
- Universal travel adapters - The competitive brands selected are as follows: Belkin, Epicka, and Xcentz. Amazon Basics adapter and Belkin's travel adapter have similar features. Epicka brand's universal adapters have a 4.7 rating out of 5, and Xcentz brand's adapters are listed as Amazon's choice on the Amazon website.

\subsection{Identification of Countries of Manufacture}

Hypotheses 1, 2, and 3 focus on whether product manufacturer country favourability and etailer reputation have any effect on the e-tailer PLs purchase likelihood. To investigate this idea, for manipulation purposes, I chose two countries (China and Mexico) as visible online labels of the place of manufacture, for the following reasons. China is geographically and culturally distant, and Mexico is closer in terms of proximity and culture to the US. Both countries are in the top ten list of 'countries by share of global manufacturing output in 2018' (Ritcher, 2020). China is the world's manufacturing hub, which accounted for $28 \%$ of global manufacturing output in 2018, which is more than $10 \%$ percentage points ahead of the United States. Mexico stands last in the top ten countries by share of global manufacturing with a $1.5 \%$ share (Ritcher, 2020). Around the globe, people's opinions towards China are divided. A survey across 34 countries revealed that only a median of $40 \%$ have a favorable view of China, whereas, in the US, the percentage of the population who voted unfavorably towards China is 60\% (Silver et al., 2019). A report by Lalloggia (2018), published in Pew research, says that $39 \%$ of Americans feel good towards Mexico, while 26\% are neutral.

\subsection{Experimental e-tailer website development}

An online website was developed for this research in order for this investigation to take place in a realistic setting rather than a traditional pen and paper test. I have chosen Shopify, a commerce platform that lets its users create, customize, and host online stores. The website I have developed is a replica of an actual e-commerce store. However, the only difference is that users could not actually make a purchase transaction. Also, a statement appears on the homepage mentioning that "this website is for research purposes only". As this website was used for both study 1 and study 2, website pages were changed in accordance with the study requirements. As study 1 contains two PL brands, two countries, and three product categories, there are 12 pages on this site other than Home, About Us, and Contact pages. For study 2, there are 24 product pages. Every page has four products, one PL brand (either Amazon Basics or DigiShack), and three NBs, depending on the product category. Amazon and other competitor brands' product images and product information on this site are downloaded from the Amazon.com website. Product info includes price, color, discount (if any), and place of 
manufacturing, etc. As DigiShack is a made-up brand for this research, Amazon PL brands images are used, but Amazon's store brand name "Amazon Basics" is replaced with DigiShack, and product information is kept the same as Amazon Basics info. I have designed the website in such a way that the number of product pages and access to those pages is hidden using a drop-down menu, so the respondents would not understand what I am trying to study through this experiment. Access to the product pages was given to the respondents through hyperlinks placed in the questionnaire.

Figure 4: Sample website page for study 2.
$\equiv$

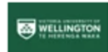
2 Q

\section{Iphone Lightning cables}

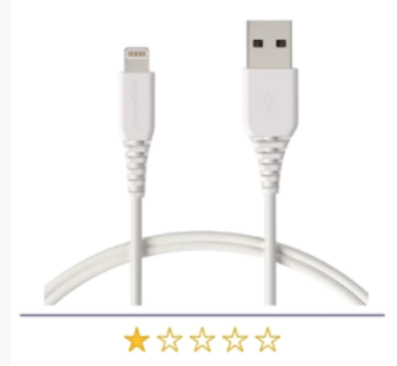

AmazonBasics iPhone Cable - $\mathbf{s 7 . 4 9}$

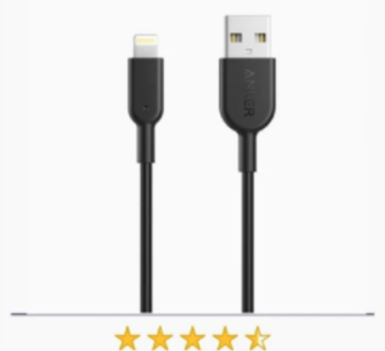

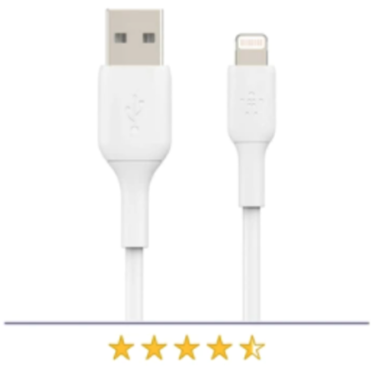

Belkin iPhone Charging Cable - \$14.99

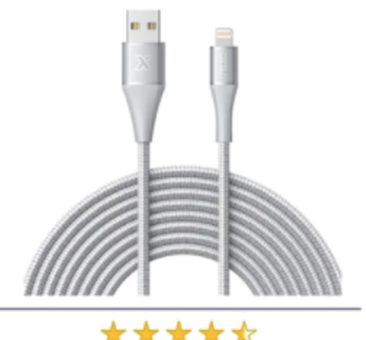




\subsection{Research instrument development}

The questionnaire for this study was developed using a web-based survey tool Qualtrics. This powerful tool allows its users to build and, distribute surveys, and analyze responses - all from any online location.

A self-administered questionnaire was developed using existing scales as measures of an instrument adapted from previous studies. This study's theoretical framework was based on the S-O-R (Mehrabian \& Russell, 1974) framework. The questionnaire consists of five sections. The first section contains the filter questions. Respondents are allowed to further sections only if their profile matches the required criteria, i.e., they need to be iPhone users and residents of the United States, the reason being that the, US is the second largest e-commerce market in the world (Business.com, 2020), and around 47\% of the mobile users are using an iPhone (O'Dea, 2021). There is an ethnicity-related question followed by elimination questions.

Section two contains brief information on how to answer the questions. The third section consists of purchase intention and actual purchase likelihood-related questions for all three categories.

As mentioned in Table 4.1, this section is further divided into four blocks. Each block has PL brand products related to either of the countries along with three other NB products (e.g., Block one has Amazon PL products tagged as 'Made in China' along with NB products, and block four has DigiShack PL brand products tagged as 'Made in Mexico' along with three other NB products). A few questions have hyperlinks that take respondents to the appropriate website page related to the question they are answering. Amazon Basics and DigiShack product manufacturers' details are manipulated to study purchase likelihood effects. The questionnaire is designed in such a way that each respondent can view and respond to only one of these blocks (randomly assigned), keeping sections one, two, four, and five sections constant for all the respondents (refer to the appendix for questionnaire).

\begin{tabular}{|c|c|}
\hline Block 1 & Amazon Basics Made in China \\
\hline Block 2 & Amazon Basics Made in Mexico \\
\hline Block 3 & DigiShack Made in China \\
\hline Block 4 & DigiShack Made in Mexico. \\
\hline
\end{tabular}

Table 4.1: Questionnaire 1 - section 3-blocks 
As mentioned in Table 4.2, this section is further divided into eight blocks. Each block has PL brand products either labelled as high rating or low rating along with three other NB products labelled as high or low rating (e.g., block one has both Amazon PL and NB products labelled with a high rating and block six has DigiShack PL labelled with a high rating whereas, NB products have a low rating).

\begin{tabular}{|c|c|c|}
\hline & Amazon Rating & NBs rating \\
\hline Block 1 & High & High \\
\hline Block 2 & High & Low \\
\hline Block 3 & Low & High \\
\hline Block 4 & Low & Low \\
\hline & DigiShack Rating & NBs rating \\
\hline Block 5 & High & High \\
\hline Block 6 & High & Low \\
\hline Block 7 & Low & High \\
\hline Block 8 & Low & Low \\
\hline
\end{tabular}

Table 4.2: Questionnaire 2 - section 3 - blocks

Section four has a question related to the S-O-R framework's Pleasure-Arousal-Dominance scale developed by Mehrabian and Russell (1974) and another question on respondent's favourability towards five countries (Mexico, South Korea, Russia, China, and India) for experiment 1 .

The final and fifth section has demographic related questions.

As mentioned in Table 4.1 and 4.2, there are three blocks in study 1 and eight blocks in study 2. To present these blocks randomly to respondents, I have used 'Randomizer' option provided in the Qualtrics tool. This option gives a choice to decide on how to present blocks to the respondents. For this study, only one block needs to be shown randomly, and also every block should present evenly so that all blocks will receive equal responses. Hence, I have used a randomizer and evenly present elements options so that each block is presented randomly and evenly to the respondents.

\subsection{Data collection}

The Qualtrics tool provides different options through which we can collect data. I chose to generate an anonymous link for this study, and whoever has the link can have access to the questionnaire. Amazon Mechanical Turk (Mturk) is a crowdsourcing marketplace where users 
can post a job by providing information such as the amount we are willing to pay for performing the task, link to access the questionnaire, time allotted to finish the work, and how many unique workers can take the survey. Interested workers can gain access to the anonymous link and answer the questionnaire. The Qualtrics tool stores both completed and partially filled responses. All the collected information is then exported into SPSS accessible file .sav for further analysis.

\section{Chapter 5}

\section{Experiment 1: e-Tailer Reputation and Country Favourability}

\subsection{Study Purpose}

The purpose of this experiment is to find a) the effect of e-tailer reputation on the purchase likelihood of PLs and b) the effect of products manufacturers' country on the purchase likelihood of PLs.

\subsection{Study design and participants}

The hypotheses were tested using 2 × 2 × 3 Factorial mixed method design where I manipulated e-tailer reputation (Amazon vs DigiShack) x Country favourability (China vs Mexico) $\mathrm{x}$ Product Categories (A vs B vs C). E-tailer reputation and Country favourability are measured between subjects, whereas Product Categories are measured within-subjects.

\begin{tabular}{|cc|}
\hline \multicolumn{2}{|c|}{ Income Range } \\
\hline Less than $\mathbf{2 5 k}$ & 20 \\
25k to 50k & 58 \\
50k to 100k & 125 \\
100k to 200k & 52 \\
Above 200k & 9 \\
Male Gender & 154 \\
Female & 110 \\
\hline
\end{tabular}

Table 5.1: Study 1 - Demographics of participants

As mentioned in Table 5.1, 58.3\% percent of respondents are male and $41.6 \%$ are female. The majority $(47.3 \%)$ of them are in the income range of $50 \mathrm{k}$ to $100 \mathrm{k}$. Respondents with less than $25 \mathrm{k}$ income are about $7.5 \%, 22 \%$ of them are earning between $25 \mathrm{k}$ and $50 \mathrm{k}, 19.7 \%$ respondents are earning between $100 \mathrm{k}$ and $200 \mathrm{k}$, and only $3.5 \%$ of them are earning above $200 \mathrm{k}$. 


\subsection{Procedure}

Participants were invited to this study through the Amazon Mechanical Turk crowdsourcing website. There I posted a job by mentioning that the respondents need to be an US resident and should be an iPhone user. Any interested worker who accepted the job, got access to the Qualtrics questionnaire link. To filter out respondents who were not eligible, respondents had to first answer screening questions. Eligible respondents were automatically allotted to any one of the blocks randomly.

Respondents were given instructions to click on the given hyperlinks which would guide them a product page. From there they had to choose a product, and then select it from the list given in the survey questions. They were asked to choose one product out of four (one PL and three NB products). Followed by that, they were to mention on a scale of 5 (extremely unlikely to extremely likely) how likely they were to purchase those brands next time they consider buying a similar product. As there were three product categories, respondents had to choose one product from every category and mention their future purchase likelihood for brands in all three categories. Wherever required, questions in these blocks had hyperlinks that took respondents to the appropriate website page to help them choose a product by comparing the product prices, features, design, etc.,

\subsection{Dependent Variables}

This study involves two dependent variables: a) future purchase intention and b) actual choice. These two dependent variables are measured for all the three product categories. The independent variables e-tailer reputation and product manufacturer's country are manipulated to understand their effects on the dependent variables.

Dependent variables were operationalized in this study using the below mentioned questions. Respondents had to answer these questions for all three categories irrespective of which block they were answering. 
Please click on the hyperlink below and decide which product you would prefer to purchase, then select it from the list below.

https://storebrandz.myshopify.com/admin/themes/104982904995/editor\#/collections/storebrand-1

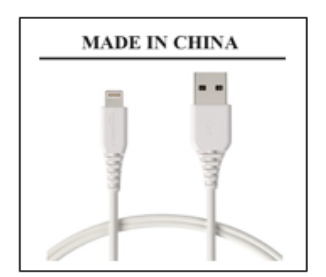

AmazonBasics

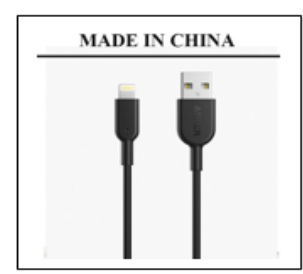

Anker

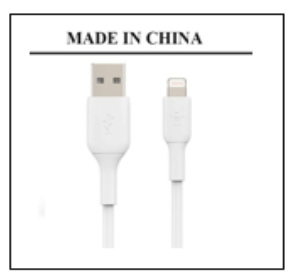

Belkin

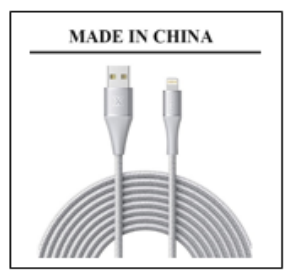

Xcentz

Figure 5: Study 1- Actual choice

How likely are you to purchase the following brands the next time you consider purchasing an iPhone cable?

\begin{tabular}{c|ccccc} 
& $\begin{array}{c}\text { Extremely } \\
\text { unlikely }\end{array}$ & $\begin{array}{c}\text { Somewhat } \\
\text { unlikely }\end{array}$ & $\begin{array}{c}\text { Neither likely } \\
\text { nor unlikely }\end{array}$ & $\begin{array}{c}\text { Somewhat } \\
\text { likely }\end{array}$ & $\begin{array}{c}\text { Extremely } \\
\text { 1ikely }\end{array}$ \\
\hline AmazonBasics & 0 & 0 & 0 & 0 \\
Belkin & 0 & 0 & 0 & 0 \\
Anker & 0 & 0 & & \\
\hline
\end{tabular}

Figure 6: Study 1 - Purchase intention

As mentioned in Figure 4, respondents had to click on the hyperlink that would take to them to the appropriate product page. There they could decide on their preferred choice, then select it from the list mentioned in the questionnaire. After that, in the next question (figure 5) they were asked to mention on a scale of 5 (extremely unlikely to extremely likely), if in future they had to purchase a similar product, how likely were they to purchase the following brands?

\subsection{Manipulation checks}

As the main idea of this study is find the effects of e-tailer reputation and manufacturer's country on the purchase of PL products, it is important to make sure the participants were observing the PL brands (Amazon and DigiShack) and countries. So, the following questions were asked to make sure respondents were noticing PLs and countries.

For the blocks with DigiShack as the PL, Amazon was replaced with DigiShack in the question. 
Indicate the extent to which you agree with the following statement.

\begin{tabular}{|c|c|c|c|c|c|c|c|}
\hline & $\begin{array}{l}\text { Strongly } \\
\text { disagree }\end{array}$ & Disagree & $\begin{array}{c}\text { Somewhat } \\
\text { disagree }\end{array}$ & $\begin{array}{l}\text { Neither } \\
\text { agree nor } \\
\text { disagree }\end{array}$ & $\begin{array}{c}\text { Somewhat } \\
\text { agree }\end{array}$ & Agree & $\begin{array}{c}\text { Strongly } \\
\text { agree }\end{array}$ \\
\hline $\begin{array}{l}\text { Amazon is } \\
\text { an e- } \\
\text { retailer } \\
\text { with good } \\
\text { reputation }\end{array}$ & 0 & 0 & $\mathrm{O}$ & O & 0 & O & $\mathrm{O}$ \\
\hline
\end{tabular}

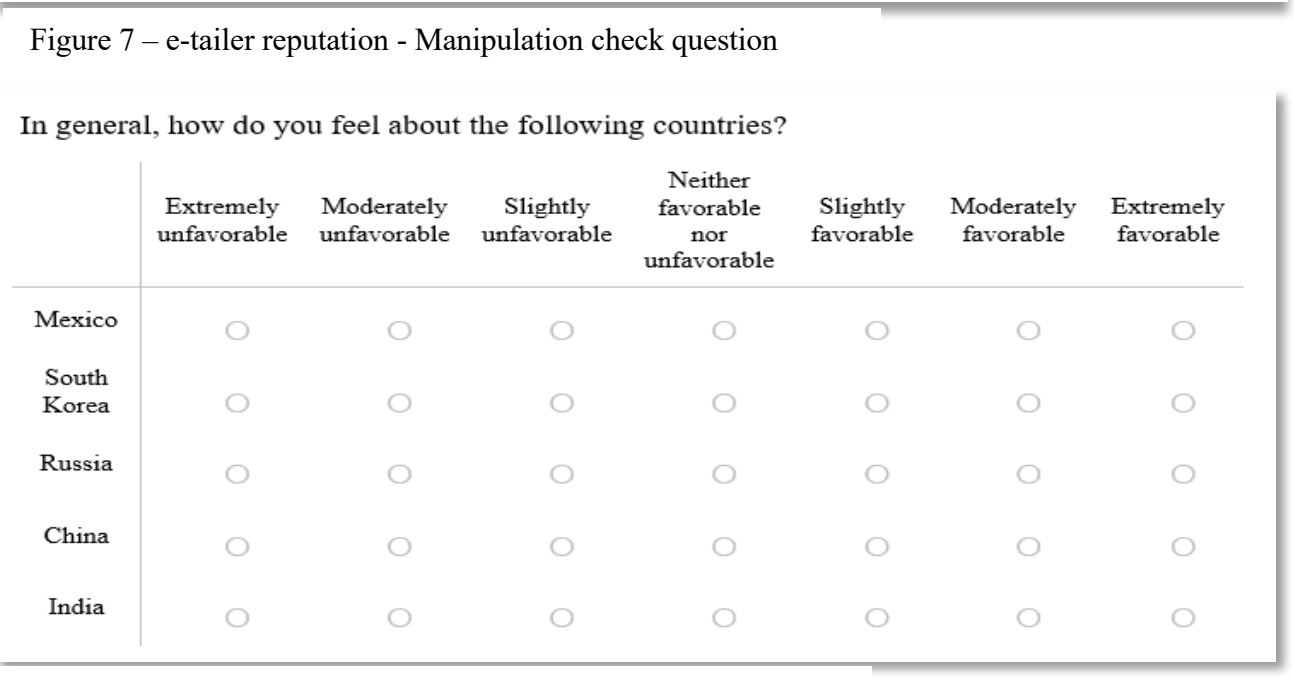

Figure 8 - Country favourability - Manipulation check question

\subsubsection{Manipulation check results:}

I have used Independent T-test and Paired samples test to analyse the results.

Independent samples T-test results revealed that the mean values for $\mathrm{M}_{\text {Amazon_Bascis }}=5.9$ (vs) $\mathrm{M}_{\text {DigiShack }}=5.4$ ) is significantly different as $\mathrm{t}_{258.35}=3.210, p=0.002$. (refer to appendices $22 \&$ 23).

Paired samples T-test revealed that the mean values for $\mathrm{M}_{\text {China }}=4.7$ (vs) $\mathrm{M}_{\text {Mexico }}=5.3$ are significantly positively correlated as $r=0.313$ and $p<0.001$ and there is a significant average difference between China and Mexico $\left(\mathrm{t}_{264}=5.147, p<0.001\right.$ (refer to appendices $\left.24 \& 25\right)$.

Based on the above results it is clear that the manipulation checks worked, as Amazon PL mean value is higher than DigiShack. Hence Amazon is considered more reputable, and Mexico is rated more favourable than China.

\subsection{Analysis and Results}

To test the impact of e-tailer reputation and product manufacturer's country on purchase likelihood, I have used the analysis of variance, mixed design-repeated measures ANOVAs. 
This method allows us to understand if there is an interaction amongst: within-subject factor and between-subject factor on the dependent variable.

To test the effect of e-tailer reputation and manufacturer's country on actual purchase, I have used binary logistic regression. This method allows us to understand the relationship between one dependent (outcome) variable and one or more independent (predictor) variables.

\begin{tabular}{|c|c|c|c|c|c|c|}
\hline Source & $\begin{array}{c}\text { Type III Sum of } \\
\text { Squares }\end{array}$ & df & $\begin{array}{c}\text { Mean } \\
\text { Square }\end{array}$ & F & Sig. & $\begin{array}{c}\text { Partial Eta } \\
\text { squared }\end{array}$ \\
\hline Intercept & 11814.387 & 1 & 11814.387 & 4.709 .325 & .000 & .947 \\
\hline e-tailer reputation & 12.076 & 1 & 12.076 & 4.813 & .029 & .018 \\
\hline Country favourability & .253 & 1 & .253 & .101 & .751 & .000 \\
\hline $\begin{array}{c}\text { e-tailer reputation*country } \\
\text { favourability }\end{array}$ & 1.065 & 1 & 1.065 & .424 & .515 & .002 \\
\hline Error & 654.776 & 261 & 2.509 & & & \\
\hline
\end{tabular}

Table 5.2 - Study 1: Tests of between subjects effects

Table 5.2 shows the ANOVA table for the main effect of e-tailer reputation and product manufacturer's country favourability. And it reveals a significant effect of e-tailer reputation because as the sig. value is .02, a non-significant effect of the country favourability as the sig. value is .75 , higher than the standard cut-off point of .05 . Also, no significant interaction is found among e-tailer reputation and country favourability.

For Amazon Basics PL products, the e-tailer reputation is high $\left(\mathrm{M}_{\text {Amazon_Bascis }}=4\right.$ (vs) $\mathrm{M}_{\text {DigiShack }}$ =3.7), which, according to (Hla) should lead to greater purchase intention. Data also supported this statement as the values are significant. $F(1,261)=4.8, p=.02, n p^{2}=.01(H 1 a)$.

According to $(\mathrm{H} 2 \mathrm{a})$ for PLs from Mexico, the purchase intention should be higher as it is from a favourable country $\left(\mathrm{M}_{\text {China }}=3.83(\mathrm{vs}) \mathrm{M}_{\text {Mexico }}=3.88\right)$. However, data do not support this statement as the values are not significant. $F(1,261)=.10, n s, n p^{2}<.001(H 2 a)$.

According to $(\mathrm{H} 3 \mathrm{a}$ ), for PLs that are from Amazon Basics and are manufactured in Mexico, the purchase intention should be greater as the product is offered by an e-tailer with a high reputation and is manufactured in a country with a favourable-country image. But our data do not support this hypothesis as the interaction effect is not significant. $F(1,261)=.42, n s, n p^{2}$ $=.002(H 3 a)$.

For all the effects, both significant and non-significant yielded small effect sizes. 


\begin{tabular}{|c|c|c|c|c|c|c|c|c|c|c|}
\hline \multicolumn{2}{|c|}{} & \multicolumn{3}{|c|}{ iPhone cables } & \multicolumn{2}{c|}{ Bluetooth speakers } & \multicolumn{2}{c|}{ Universal adapter } \\
\hline \multicolumn{2}{|c|}{} & B & S.E. & $\operatorname{Exp}(\mathrm{B})$ & B & S.E. & Exp(B) & B & S.E. & Exp(B) \\
\hline $\begin{array}{c}\text { Step } \\
1^{\mathrm{a}}\end{array}$ & e-tailer reputation & -.44 & .64 & .64 & -.52 & .58 & .58 & -.35 & .27 & .70 \\
\hline $\begin{array}{c}\text { Block } \\
1\end{array}$ & Country favourability & $.66^{*}$ & 1.94 & 1.94 & $.67 *$ & 1.96 & 1.96 & .37 & .27 & 1.45 \\
\cline { 2 - 12 } & Constant & $-.89^{*}$ & .40 & .40 & -1.33 & .26 & .26 & -.93 & .24 & .39 \\
\hline $\begin{array}{c}\text { Step } \\
1^{\text {a }}\end{array}$ & $\begin{array}{c}\text { e-tailer reputation } \\
\text { Block } \\
2\end{array}$ & -.56 & .56 & .56 & -.72 & .48 & .48 & -.56 & .41 & .56 \\
\cline { 2 - 12 } & $\begin{array}{c}\text { Country favourability } \\
\text { reputation*country } \\
\text { favourability }\end{array}$ & .56 & 1.76 & 1.76 & .53 & 1.71 & 1.71 & .19 & .37 & 1.21 \\
\cline { 2 - 11 } & Constant & $-.84^{*}$ & .43 & .43 & -1.25 & .28 & .28 & -.84 & .27 & .43 \\
\hline
\end{tabular}

Table 5.3 - Study 1: Binary logistic regression results.

* Alpha $\alpha<0.05$

Table 5.3 shows the statistical significance and impact of each independent variable for all three categories (refer appendix 4, 5, 6 for more detailed results).

For Amazon Basics PL products, the e-tailer reputation is high, which according to ( $H 1 b$,) should lead to greater actual purchase likelihood. However, data do not support this statement as the sig. values for three categories $(p=.096),(p=.07)$, and $(p=.20)$ are not significant.

As per hypothesis $(H 2 b)$ for PLs from Mexico, the actual purchase likelihood should be higher as they are from a favourable country. Data supports this statement for iPhone cables, and Bluetooth speakers as the values $(p=.014 ; \operatorname{Exp}(\mathrm{B})=1.94)$ and $(p=.02 ; \operatorname{Exp}(\mathrm{B})=1.96)$ are significant. However, for universal adapters $(p=.20$, ) it is not significant. It reveals that the odds of buying a PL are 1.9 times higher if it is from a favourable country.

\subsection{Moderated Mediation Analysis}

\subsubsection{Study Purpose}

The purpose of this analysis is to find a) the moderation effect of product manufacturer country favourability and consumer online ratings on the purchase likelihood of PLs and b) the mediation effect of organism factors on the purchase likelihood of PLs.

\subsubsection{Study design and Procedure}

Hayes model 59 (experiment 1) was used to analyse the data. Data for this analysis were collected as a part of both experiments 1 and 2. Every respondent was asked to answer how 
they felt about online product information pages on a scale of 7 (Extremely negative to extremely positive). We have used the same scale used by Donovan et al. (1994) in their study to understand respondents' emotions.

Using the scale given below, please indicate how you felt about online product information pages.

\begin{tabular}{|c|c|c|c|c|c|c|c|c|}
\hline & $\begin{array}{c}\text { Extremely } \\
\text { negative } \\
(-3)\end{array}$ & $\begin{array}{l}\text { Very } \\
\text { negative } \\
(-2)\end{array}$ & $\begin{array}{c}\text { Negative } \\
(-1)\end{array}$ & Neutral & $\begin{array}{l}\text { Positive } \\
\quad(+1)\end{array}$ & $\begin{array}{c}\text { Very } \\
\text { Positive } \\
(+2)\end{array}$ & $\begin{array}{c}\text { Extremely } \\
\text { positive } \\
(+3)\end{array}$ & \\
\hline & 1 & 2 & 3 & 4 & 5 & 6 & 7 & \\
\hline Unhappy & 0 & O & O & $\mathrm{O}$ & 0 & 0 & 0 & Happy \\
\hline Annoyed & 0 & 0 & 0 & 0 & 0 & 0 & 0 & Pleased \\
\hline $\begin{array}{c}\text { Dis- } \\
\text { satisfied }\end{array}$ & $\mathrm{O}$ & 0 & O & $\mathrm{O}$ & O & 0 & 0 & Satisfied \\
\hline Melancholic & 0 & $\mathrm{O}$ & $\mathrm{O}$ & 0 & O & 0 & O & contended \\
\hline Despairing & 0 & $\mathrm{O}$ & $\mathrm{O}$ & 0 & $\mathrm{O}$ & 0 & 0 & Hopeful \\
\hline Bored & 0 & O & O & O & 0 & $\bigcirc$ & 0 & Relaxed \\
\hline Sluggish & 0 & $\mathrm{O}$ & $\mathrm{O}$ & O & 0 & O & 0 & Frenzied \\
\hline Dull & 0 & 0 & $\mathrm{O}$ & $\bigcirc$ & O & O & 0 & Jittery \\
\hline Unaroused & 0 & O & 0 & 0 & 0 & 0 & 0 & aroused \\
\hline Relaxed & 0 & $\mathrm{O}$ & $\mathrm{O}$ & $\mathrm{O}$ & O & 0 & 0 & Stimulated \\
\hline Calm & 0 & 0 & 0 & 0 & 0 & 0 & 0 & Excited \\
\hline Sleepy & 0 & $\mathrm{O}$ & 0 & 0 & 0 & 0 & 0 & $\begin{array}{c}\text { Wide } \\
\text { awake }\end{array}$ \\
\hline
\end{tabular}

Figure 9 - Moderated mediation question

\subsubsection{Results}

According to $H 7$, the effect of e-tailer reputation on purchase likelihood of the PL products should be mediated by organism factors. However, analysis results (Table 5.4 and Table 5.5) do not support this statement, as values are not statistically significant and the null of zero falls between the lower and upper limits (refer appendices 20 and 21 for Conditional indirect effects results). 
As per $H 8$, the effect of product manufacturer's country on the purchase likelihood of the PL products should be mediated by organism factors. However, (Table 5.4 and Table 5.5) data infer that the manufacturer's country does not moderate the PL purchase likelihood's indirect effect, as the values are not statistically significant and the null of zero falls between the lower and upper bounds of the confidence interval.

\begin{tabular}{|c|c|c|c|c|c|}
\hline & \multicolumn{5}{|c|}{ Index of moderated mediation } \\
\hline & \multicolumn{5}{|c|}{ Pleasure Factor } \\
\hline & & Index & BootSE & BootLLCI & BootULCI \\
\hline iPhone cables & $\begin{array}{l}\text { e-tailer reputation - Country } \\
\text { favourability }\end{array}$ & .0136 & 1001 & -.1781 & .2164 \\
\hline $\begin{array}{l}\text { Bluetooth } \\
\text { speakers }\end{array}$ & $\begin{array}{l}\text { e-tailer reputation - Country } \\
\text { favourability }\end{array}$ & .0507 & .1133 & -.1640 & .2789 \\
\hline $\begin{array}{l}\text { Universal } \\
\text { adapters }\end{array}$ & $\begin{array}{l}\text { e-tailer reputation - Country } \\
\text { favourability }\end{array}$ & .0447 & .1089 & -.1646 & .2670 \\
\hline
\end{tabular}

Table 5.4: Study 1 - Moderated mediation - Pleasure factor results

\begin{tabular}{|c|c|c|c|c|c|}
\hline & \multicolumn{5}{|c|}{ Index of moderated mediation } \\
\hline & \multicolumn{5}{|c|}{ Arousal Factor } \\
\hline & & Index & BootSE & BootLLCI & BootULCI \\
\hline iPhone cables & $\begin{array}{l}\text { e-tailer reputation - Country } \\
\text { favourability }\end{array}$ & -.0074 & .0923 & -.1826 & .1828 \\
\hline $\begin{array}{l}\text { Bluetooth } \\
\text { speakers }\end{array}$ & $\begin{array}{l}\text { e-tailer reputation - Country } \\
\text { favourability }\end{array}$ & -.0092 & .1036 & -.2087 & .2032 \\
\hline $\begin{array}{l}\text { Universal } \\
\text { adapters }\end{array}$ & $\begin{array}{l}\text { e-tailer reputation - Country } \\
\text { favourability }\end{array}$ & -.0095 & .1115 & -.2246 & .2193 \\
\hline
\end{tabular}

Table 5.5: Study 1 - Moderated mediation - Arousal factor results

\subsection{Assumption and Robustness Checks}

\subsubsection{Assumptions}

In this section, I discuss both assumption checks for the model used and robustness checks of the data. The within-subject factors table: (refer to appendix 1) Q7_1 dependent variable holds information of both Amazon and DigiShack iPhone lightning cables. It includes all the data from the four scenarios: Amazon Basics iPhone cables (made in China), Amazon Basics iPhone cables (made in Mexico), DigiShack iPhone lightning cables (made in China), and DigiShack iPhone lightning cables (made in Mexico). Q9_1 dependent variable holds information of both Amazon and DigiShack Bluetooth speakers. Q11_1 dependent variable has information of both Amazon and DigiShack Universal travel adapters.

In this study, only the data from PL product manufacturers' country data have been manipulated, but the NB products information is kept original.

The table between-subject factors (refer to appendix 2), PL represents private label, and COO denotes manufacturers' country. PL-0 represents AmazonBasics products and PL-1 represents 
DigiShack products. COO-0 represents Made in China, and COO-1 represents Made in Mexico.

\subsubsection{Mauchly's Test of Sphericity}

A commonly used and formal way of testing sphericity's assumption is through Mauchly's test of sphericity. However, this test has been heavily critiqued for failing to identify departures from sphericity in small samples and over-detecting them in larger samples. Despite these limitations, this test is widely used for ANOVAs repeated measures (Leard statistics, n.d.)

\begin{tabular}{|c|c|c|c|c|c|c|c|}
\hline \multicolumn{8}{|c|}{ Mauchly's Test of Sphericity ${ }^{\mathrm{a}}$} \\
\hline \multicolumn{5}{|c|}{ Measure: MEASURE_1 } & \multicolumn{3}{|c|}{ Epsilon $^{\mathrm{b}}$} \\
\hline $\begin{array}{c}\text { Within } \\
\text { Subjects } \\
\text { Effect }\end{array}$ & Mauchly's W & $\begin{array}{c}\text { Approx. Chi- } \\
\text { Square }\end{array}$ & $\mathrm{df}$ & Sig. & $\begin{array}{c}\text { Greenhouse- } \\
\text { Geisser }\end{array}$ & $\begin{array}{l}\text { Huynh- } \\
\text { Feldt }\end{array}$ & $\begin{array}{l}\text { Lower- } \\
\text { bound }\end{array}$ \\
\hline Category & .951 & 13.031 & 2 & .001 & .953 & .971 & .500 \\
\hline
\end{tabular}

Table 5.6 - Mauchly's test of sphericity results

Mauchly's sphericity test indicated (Table 5.6) that sphericity's assumption had been violated, as the significance value (.01) is less than the critical value of .05. As sphericity's assumption has been violated, corrections need to be made based on Greenhouse-Geisser (1959) and Huynh and Feldt (1976). Both provide a correction factor that can be applied to the degrees of freedom used to assess the observed $F$-ratio. According to Andy Field (2009), the closer the Greenhouse-Geisser is to 1 , the more homogenous the variances of differences, and the closer the data to being spherical. In this case, Greenhouse-Geisser is .953 and is closer to 1 . Therefore, it is assumed that data deviation from sphericity is minimal. $x^{2}(2)=13.031, \mathrm{P}=$ .001 .

Tests of within-subjects effects table (refer to appendix 3) displays the summary of the repeated-measures effects in the ANOVA with corrected F-values. There is a significant main effect of category. If, whether the product is a PL or a NB and whether the product is manufactured in China or Mexico is ignored, then the product category affected its purchaselikelihood. But, results indicate no significant interaction between category and PL, among category and country, and between categories, PL and Country. $F(2,522)=2.98, p=0.51$, $\eta p^{2}=.01$ 


\subsubsection{Robustness Check}

To check the data quality and whether conclusions hold in different conditions, responses answered under 200 seconds were eliminated and performed repeated measures mixed design ANOVAs. Before posting the job in Mturk to collect responses, I have sent the questionnaire to 5 potential respondents and checked the minimum time required to answer the questionnaire. All of them took a minimum of 190 to 200 seconds to finish answering the questionnaire. Based on this criteria I have removed the responses answered under 200 seconds to check the robustness of data.

\begin{tabular}{|c|c|c|c|c|c|c|c|}
\hline \multicolumn{7}{|c|}{ Mauchly's Test of Sphericity } \\
\hline \multicolumn{2}{|c|}{ Measure: } & MEASURE_1 \\
\hline $\begin{array}{c}\text { Within Subjects } \\
\text { Effect }\end{array}$ & $\begin{array}{c}\text { Mauchly's } \\
\text { W }\end{array}$ & $\begin{array}{c}\text { Approx. Chi- } \\
\text { Square }\end{array}$ & df & Sig. & $\begin{array}{c}\text { Greenhouse- } \\
\text { Geisser }\end{array}$ & $\begin{array}{c}\text { Huynh- } \\
\text { Feldt }\end{array}$ & $\begin{array}{c}\text { Lower- } \\
\text { bound }\end{array}$ \\
\hline Category & .966 & 5.535 & 2 & .063 & .968 & .997 & .500 \\
\hline
\end{tabular}

Table 5.7 - Mauchly's test of sphericity - Robustness check results

Mauchly's test of sphericity (Table 5.7) indicated that the assumption of sphericity had not been violated. $x^{2}(2)=5.535, \mathrm{P}=.063$.

\begin{tabular}{|c|c|c|c|c|c|c|}
\hline \multicolumn{7}{|c|}{ Tests of Between-Subjects Effects } \\
\hline Source & $\begin{array}{c}\text { Type III Sum of } \\
\text { Squares }\end{array}$ & $\mathrm{df}$ & $\begin{array}{c}\text { Mean } \\
\text { Square }\end{array}$ & $\mathrm{F}$ & Sig. & $\begin{array}{c}\text { Partial Eta } \\
\text { squared }\end{array}$ \\
\hline Intercept & 7780.678 & 1 & 7780.678 & 3222.570 & .000 & .952 \\
\hline e-tailer reputation & 20.582 & 1 & 20.582 & 8.525 & .004 & .050 \\
\hline $\begin{array}{c}\text { Country favourability } \\
\text { e-tailer reputation* country } \\
\text { favourability }\end{array}$ & 6.827 & 1 & 6.827 & 2.828 & .095 & .017 \\
\hline Error & .509 & 1 & .509 & .211 & .647 & .001 \\
\hline
\end{tabular}

Table 5.8 - Test of between subject effects - Robustness results.

Table 5.8 shows the ANOVA table for the main effect of e-tailer reputation and product manufacturer's country favourability. And it reveals a significant effect of e-tailer reputation as the sig. value is $<.001$, a non-significant effect of the country favourability, as the sig. value is .95 higher than the standard cut-off point of .05. Also, no significant interaction is found among e-tailer reputation and country favourability.

For Amazon Basics PL products, the e-tailer reputation is high which according to $(\mathrm{H} / \mathrm{a})$, should lead to greater purchase intention. Data also supported this statement as the values are significant. $F(1,163)=8.52, p=.004, n p^{2}=.05($ H1a) . 
According to (H2a) for PLs from Mexico, the purchase intention should be higher as it is from a favourable country. However, data do not support this statement as the values are not significant. $F(1,163)=2.82, p=.09, n p^{2}=.01(H 2 a)$.

According to $(\mathrm{H} 3 \mathrm{a}$ ), PLs that are from Amazon Basics and are manufactured in Mexico, the purchase intention should be greater as the product is offered by an e-tailer with a high reputation and manufactured in a country with a favourable-country image. But, current data do not support this hypothesis as the interaction effect is not significant. $F(1,163)=.21, p=$ $.647, n p^{2}=.001(H 3 a)$.

\subsubsection{Binary logistic regression}

In binary logistic regression analysis bootstrapping was performed to measure data accuracy. The upper and lower bound values do not cross zero for the variables that are significant (refer appendices 7, 8, and 9). So, I can conclude that the results are accurate.

From the above results, it is clear that the robustness results are also consistent with previous results.

\section{Chapter 6}

\section{Experiment 2: e-tailer Reputation and Online Product Rating}

\subsection{Study Purpose}

The purpose of this experiment is to find a) the effect of e-tailer reputation on the purchase likelihood of PLs and b) the effect of consumer online rating on the purchase likelihood of PLs.

\subsection{Study design and participants}

The hypotheses were tested using $2 \times 2 \times 3$ Factorial mixed method design (Amazon vs DigiShack) x Consumer online rating (High rating vs Low rating) x Product Categories (A vs B vs C). In this experiment I have manipulated both e-tailer reputation and consumer online rating. E-tailer reputation and consumer online rating are measured between subjects, whereas product categories are measured within-subjects. 


\begin{tabular}{|cc|}
\hline \multicolumn{2}{|c|}{ Income Range } \\
\hline Less than 25k & 36 \\
25k to 50k & 97 \\
50k to 100k & 189 \\
100k to 200k & 56 \\
Above 200k & 7 \\
Prefer not to say & 31 \\
Gender & \\
Male & 221 \\
Female & 171 \\
Prefer not to say & 24 \\
\hline
\end{tabular}

Table 6.1 - Study 2 - Demographics of participants

As mentioned in Table 6.1, 53.1\% percent of respondents are male, $41.1 \%$ are female, and $5.7 \%$ selected prefer not to say or left it blank. Majority of the respondents are in the income range $50 \mathrm{k}$ to $100 \mathrm{k}(45.4 \%)$. Respondents with less than $25 \mathrm{k}$ income are about $8.65 \%, 23.23 \%$ of them are earning between $25 \mathrm{k}$ to $50 \mathrm{k}, 13.4 \%$ respondents are earning between $100 \mathrm{k}$ to $200 \mathrm{k}$, and only $1.6 \%$ of them are earning above $200 \mathrm{k}$.

\subsection{Procedure}

Participants who were invited to this study were also through the Amazon Mechanical Turk crowdsourcing website. The same procedure was used to provide access to the questionnaire and for filtering respondents based on the two requirements: a) being a US resident and, b) an iPhone user.

Respondents were given similar instructions as in experiment 1, to click on the given hyperlink and choose one product from the list in the survey questions. Followed by that they were asked to mention on a scale of 5 how likely they were to purchase given brands next time they consider buying a similar product.

\subsection{Dependent Variables}

This study involves two types of dependent variables: a) future purchase intention and b) actual choice (or) purchase intention of shoppers. These two dependent variables are measured for all three product categories. The independent variables, e-tailer reputation and consumer online ratings are manipulated to understand their effects on the dependent variables. 
Dependent variables were operationalized in this study using the questions below. Respondents had to answer these questions for all three categories irrespective of which block they were answering.

Please click on the hyperlink below and decide which product you would prefer to purchase, then select it from the list below.

\section{https://storebrandz.myshopify.com/collections/iphone-lightning-cable-abll}

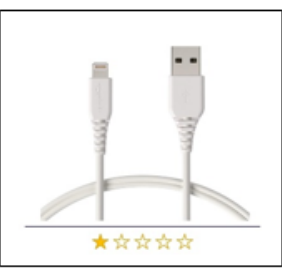

AmazonBasics

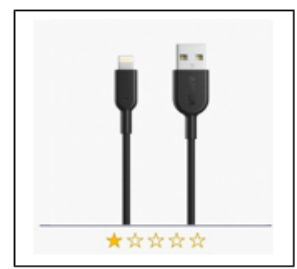

Anker

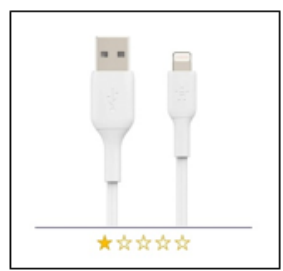

Belkin

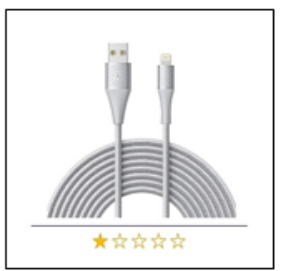

Xcentz

Figure 10: Study 2: Actual purchase

How likely are you to purchase the following brands the next time you consider purchasing an iPhone cable?

$$
\text { Extremely }
$$
unlikely Somewhat Neither likely nor unlikely Somewhat Extremely

AmazonBasics unlikely likely likely

Belkin

Anker

Xcentz

Figure 11: Study 2: Purchase intention

\subsection{Manipulation checks}

As the primary idea of this study is find the effects of e-tailer reputation and consumer online ratings on the purchase of PL products, it is important to make sure they were observing the PL brands (Amazon and DigiShack) and NBs. Hence, the following questions were asked to make sure respondents were noticing PLs and NBs ratings.

For the blocks with DigiShack as the PL, Amazon was replaced with DigiShack in the question.

Indicate the extent to which you agree with the following statement.

\begin{tabular}{|c|c|c|c|c|c|c|c|}
\hline & $\begin{array}{l}\text { Strongly } \\
\text { disagree }\end{array}$ & Disagree & $\begin{array}{c}\text { Somewhat } \\
\text { disagree }\end{array}$ & $\begin{array}{l}\text { Neither } \\
\text { agree nor } \\
\text { disagree }\end{array}$ & $\begin{array}{c}\text { Somewhat } \\
\text { agree }\end{array}$ & Agree & $\begin{array}{l}\text { Strongly } \\
\text { agree }\end{array}$ \\
\hline $\begin{array}{l}\text { Amazon is } \\
\text { an e- } \\
\text { retailer } \\
\text { with good } \\
\text { reputation }\end{array}$ & O & $\mathrm{O}$ & 0 & O & 0 & 0 & $\mathrm{O}$ \\
\hline
\end{tabular}

Figure 12 - e-tailer reputation - Manipulation check question 


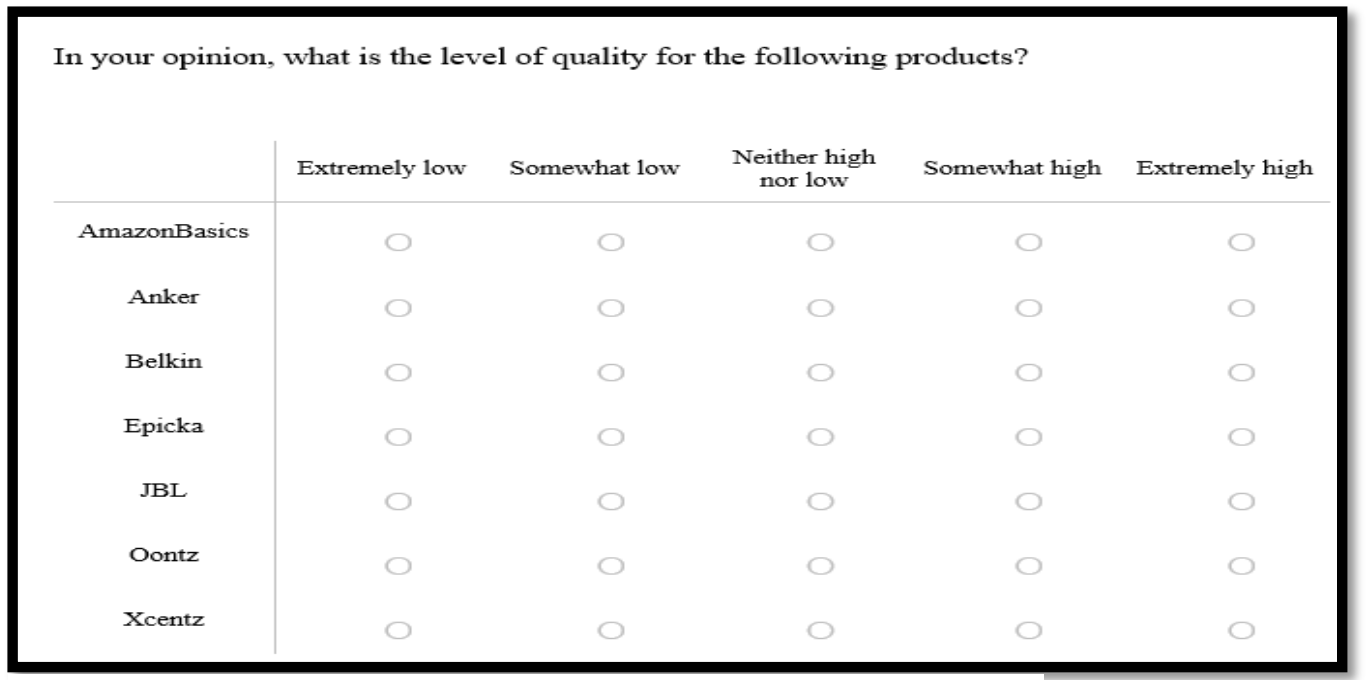

Figure 13 - e-tailer reputation \& other brands - Manipulation check question

\subsubsection{Manipulation check results}

I have used Independent T-test test to analyse the results for a) Amazon Basics and DigiShack and, b) all brands including PLs when the ratings are low and, high.

Independent samples T-test results revealed that the mean values for $\mathrm{M}_{\text {Amazon_Bascis }}=5.9$ (vs) $M_{\text {DigiShack }}=5.3$ ) is significantly different as $t_{341.53}=4.51, p<0.001$ (refer to appendix $26 \& 27$ ). Results also revealed that mean values for brands with low and high are also significantly different (refer to appendix $28 \& 29$ ).

Based on these results it is clear that the manipulation checks worked, as Amazon mean value is higher than DigiShack, hence Amazon is considered more reputable. The mean values for all the brands are higher when their online ratings are high and they are lower when their ratings are low. Which says that brands are considered of good quality when their ratings are high.

\subsection{Analysis and Results}

To test the impact of e-tailer reputation and consumer online ratings on purchase likelihood, I have used the analysis of variance, mixed design-repeated measures ANOVAs. And to test the effect of e-tailer reputation and consumer online ratings on actual purchase, I have used binary logistic regression.

For analysis purposes, study 2 data have been split into two groups (in SPSS) based on NB rating, i.e., when other brands (NB) ratings are low (0), and other brand ratings are high (1). 


\subsubsection{Section 1: When other brands (NB) ratings are Low}

Table 6.2 shows the ANOVA table for the main effect of e-tailer reputation and consumer online ratings. And it reveals a significant effect of PL and PL rating, as the sig. values are lower than the standard cut-off point 0.05 . But no significant interaction is found among PL and PL ratings.

Hypothesis $(\mathrm{Hla})$ is also tested in experiment 2. For Amazon Basics PL products, the e-tailer reputation is high $\left(\mathrm{M}_{\text {Amazon_Bascis }}=3.9\right.$ (vs) $\left.\mathrm{M}_{\text {DigiShack }}=3.4\right)$, which according to (HIa), should lead to greater purchase intention. Data also supported this statement, as the values are significant $F(1,195)=5.9, P=.01, n p^{2}=.02$.

According to $(\mathrm{H} 4 \mathrm{a})$, when PL online ratings are high, purchase intention should be higher. Data also supported this statement as the values are significant. $F(1,195)=13.5, P<.001, n p^{2}=$ .06

Amazon Basics PL with high online consumer rating, which, according to (H5a) should lead to higher purchase intention. However, data do not support this statement as the values are not significant. $F(1,195)=1.14, P<.285, n p^{2}=.006$.

The effect size for PL and PL* PL rating is very small. However, PL rating has a medium effect size.

\begin{tabular}{|c|c|c|c|c|c|c|}
\hline Source & $\begin{array}{c}\text { Type III } \\
\text { Sum of } \\
\text { Squares }\end{array}$ & df & $\begin{array}{c}\text { Mean } \\
\text { Square }\end{array}$ & F & Sig. & $\begin{array}{c}\text { Partial Eta } \\
\text { squared }\end{array}$ \\
\hline Intercept & 8078.777 & 1 & 7780.678 & 2373.074 & .000 & .924 \\
\hline e-tailer reputation & 20.161 & 1 & 20.582 & 5.922 & .016 & .029 \\
\hline $\begin{array}{c}\text { Consumer online rating } \\
\text { e-tailer reputation * consumer online } \\
\text { rating }\end{array}$ & 45.971 & 1 & 6.827 & 13.503 & .000 & .065 \\
\hline Error & 3.905 & 1 & .509 & 1.147 & .285 & .006 \\
\hline
\end{tabular}

Table 6.2: Study 2 - Test of between subject effects results (a)

\subsubsection{Section 2: When other brands (NB) ratings are high}

Table 6.3 shows the ANOVA table for the main effect of e-tailer reputation and consumer online ratings. And it reveals a significant effect of PL and PL rating, as the sig. values are 
lower than the standard cut-off point 0.05 . But, no significant interaction is found among PL and PL ratings.

For Amazon Basics PL products, the e-tailer reputation is high $\left(\mathrm{M}_{\text {Amazon_Bascis }}=3.7\right.$ (vs) $\left.\mathrm{M}_{\text {DigiShack }}=3.4\right)$ which according to $(H 1 a)$, should lead to greater purchase intention. Data also supported this statement as the values are significant $F(1,194)=4.3, P=.03, n p^{2}=.02$.

According to ( $\mathrm{H} 4 \mathrm{a}$ ), when PL online ratings are high, purchase intention should be higher. Data from this section also supports this statement as the values are significant. $F(1,194)=17.09$, $P<.01, n p^{2}=.08$

Amazon Basics PL with high online consumer rating, which, according to (H5a), should lead to higher purchase intention. However, data from section 2 do not support this statement as the values are not significant. $F(1,194)=.51, P=.47, n p^{2}=.003$.

The effect size for PL and PL* PL rating is very small. However, PL rating has a medium effect size.

\begin{tabular}{|c|c|c|c|c|c|c|}
\hline Source & $\begin{array}{c}\text { Type III } \\
\text { Sum of } \\
\text { Squares }\end{array}$ & df & $\begin{array}{c}\text { Mean } \\
\text { Square }\end{array}$ & F & Sig. & $\begin{array}{c}\text { Partial Eta } \\
\text { squared }\end{array}$ \\
\hline Intercept & 7624.512 & 1 & 7624.512 & 2388.445 & .000 & .925 \\
\hline $\begin{array}{c}\text { e-tailer reputation } \\
\text { e-tailer reputation * consumer online } \\
\text { rating }\end{array}$ & 13.877 & 1 & 13.877 & 4.347 & .038 & .022 \\
\hline Error & 54.566 & 1 & 54.566 & 17.093 & .000 & .081 \\
\hline
\end{tabular}

Table 6.3: Study 2 - Test of between subject effects results (b)

\subsubsection{Binary logistic regression}

Table 6.4 shows the statistical significance and impact of each independent variable for all three categories (refer to appendices 14, 15, and 16 for more detailed results).

The data partially support the hypothesis (H1b), as values are significant only in some cases. When other brand ratings are low: $(p=.22),(p=.10)$, and $(p=.25)$, and when other brand ratings are high: $(p=.008), p=.006)$, and $(p=.12)$.

As per hypothesis (H4b), PLs actual purchase likelihood should be greater when the online PL ratings are high. Data from the results also support this statement as the values are significant. 
When other brand ratings are low: $(p=.002),(p<.001)$, and $(p<.001)$, when other brand ratings are high: $(p<.001), p=.008)$, and $(p<.008)$.

According to $(\mathrm{H} 5 \mathrm{~b})$, for Amazon Basics products with high online consumer ratings, the actual purchase likelihood should be greater, as the product has a high online rating and they are from an e-tailer with a high reputation. But, our data do not support this hypothesis, as the interaction values are not significant. When other brand ratings are low, $(p=.11),(p=.37)$, and $(p=.28)$, and when other brand ratings are high, $(p=.20), p=.99)$, and $(p=.50)$.

\begin{tabular}{|c|c|c|c|c|c|c|c|c|c|c|c|}
\hline & \multirow{2}{*}{\multicolumn{2}{|c|}{ Other Brands Rating }} & \multicolumn{3}{|c|}{ iPhone Cables } & \multicolumn{3}{|c|}{ Bluetooth Speakers } & \multicolumn{3}{|c|}{ Universal Adapter } \\
\hline & & & \multirow{2}{*}{$\begin{array}{c}\mathrm{B} \\
-.37\end{array}$} & \multirow{2}{*}{$\begin{array}{l}\text { S.E. } \\
.31\end{array}$} & \multirow{2}{*}{$\frac{\operatorname{Exp}(\mathrm{B})}{.68}$} & \multirow{2}{*}{$\begin{array}{c}\mathrm{B} \\
-.87^{*}\end{array}$} & \multirow{2}{*}{$\begin{array}{l}\text { S.E. } \\
.33\end{array}$} & \multirow{2}{*}{$\begin{array}{c}\operatorname{Exp}(\mathrm{B}) \\
41\end{array}$} & \multirow{2}{*}{$\begin{array}{c}\mathrm{B} \\
-.35\end{array}$} & \multirow{2}{*}{$\begin{array}{l}\text { S.E. } \\
.31\end{array}$} & \multirow{2}{*}{$\begin{array}{r}\operatorname{Exp}(\mathrm{B}) \\
.69\end{array}$} \\
\hline 0 & $\begin{array}{c}\text { Step } \\
1^{\mathrm{a}}\end{array}$ & e-tailer reputation & & & & & & & & & \\
\hline \multirow{2}{*}{\multicolumn{2}{|c|}{ Block 1}} & $\begin{array}{c}\text { Consumer online } \\
\text { rating }\end{array}$ & $.97 *$ & .31 & 2.65 & $1.72 *$ & .34 & 5.59 & $1.36^{*}$ & .32 & 3.90 \\
\hline & & Constant & $-1.09 *$ & .28 & .33 & $-1.29 *$ & .30 & .27 & $-1.22 *$ & .28 & .29 \\
\hline 1 & $\begin{array}{c}\text { Step } \\
1^{\mathrm{a}}\end{array}$ & e-tailer reputation & $-1.05^{*}$ & .39 & .35 & $-1.47^{*}$ & .53 & .23 & $-1.30^{*}$ & .47 & .27 \\
\hline \multirow{2}{*}{\multicolumn{2}{|c|}{ Block 1}} & $\begin{array}{l}\text { Consumer online } \\
\text { rating }\end{array}$ & $1.47^{*}$ & .42 & 4.38 & $1.42 *$ & .53 & 4.16 & $1.25^{*}$ & .47 & 3.50 \\
\hline & & Constant & $-1.87 *$ & .37 & .15 & $-2.39 *$ & 47 & .09 & $-2.07 *$ & .41 & .12 \\
\hline 0 & $\begin{array}{c}\text { Step } \\
1^{\mathrm{a}}\end{array}$ & e-tailer reputation & $-.99 *$ & .51 & .37 & $-1.31^{*}$ & .61 & .27 & -.79 & .51 & .45 \\
\hline \multirow{3}{*}{\multicolumn{2}{|c|}{ Block 2}} & $\begin{array}{c}\text { Consumer online } \\
\text { rating }\end{array}$ & .52 & .42 & 1.69 & $1.47^{*}$ & .43 & 4.37 & $1.04^{*}$ & .42 & 2.84 \\
\hline & & $\begin{array}{c}\text { e-tailer reputation by } \\
\text { Consumer online } \\
\text { rating }\end{array}$ & 1.02 & .65 & 2.79 & .65 & .74 & 1.91 & .70 & .65 & 2.03 \\
\hline & & Constant & $-.84 *$ & .30 & .42 & $-1.15^{*}$ & .33 & .31 & $-1.04 *$ & .32 & .35 \\
\hline 1 & $\begin{array}{c}\text { Step } \\
1^{\mathrm{a}}\end{array}$ & e-tailer reputation & $-2.23 *$ & 1.08 & .10 & -1.47 & 1.13 & .22 & -1.92 & 1.10 & .14 \\
\hline \multirow{3}{*}{\multicolumn{2}{|c|}{ Block 2}} & $\begin{array}{c}\text { Consumer online } \\
\text { rating }\end{array}$ & $1.11^{*}$ & .48 & 3.04 & $1.42^{*}$ & .60 & 4.16 & $1.07^{*}$ & .53 & 2.91 \\
\hline & & $\begin{array}{c}\text { e-tailer reputation by } \\
\text { Consumer online } \\
\text { rating }\end{array}$ & 1.49 & 1.17 & 4.4 & .00 & 1.29 & 1.03 & .80 & 1.22 & 2.24 \\
\hline & & Constant & $-1.63 *$ & .38 & .19 & $-2.39 *$ & .52 & .09 & $-1.94 *$ & .43 & .14 \\
\hline
\end{tabular}

Table 6.4: Study 2: Binary logistic regression results.

* Alpha $\alpha<0.05$ 


\subsection{Moderated Mediation effects}

\subsubsection{Study Purpose}

The purpose of this analysis is to find: a) the moderation effect of product manufacturer country favourability and consumer online ratings on the purchase likelihood of PLs and b) the mediation effect of organism factors on the purchase likelihood of PLs.

\subsubsection{Study design and Procedure}

Hayes model 73 (experiment 2) was used to analyse the data. Data for this analysis was collected as a part of both experiments 1 and 2. Every respondent was asked to answer how they felt about online product information pages on a scale of 7 (Extremely negative to extremely positive). I have used the same scale used by Donovan et al., (1994) in their study to understand respondents' emotions.

\subsubsection{Results}

According to $H 9$, the effect of online consumer rating on the purchase likelihood of the PL products should be mediated by organism factors. However, (Table 6.5 and 6.6) data infer that online consumer rating do not moderate the indirect effect of PL purchase likelihood, as the null of zero falls between the lower and upper bounds of the confidence interval.

\begin{tabular}{|c|c|c|c|c|c|c|}
\hline \multicolumn{7}{|c|}{ Conditional Indirect Effects } \\
\hline \multirow{4}{*}{ iPhone cables } & PL Rating & NB Rating & Effect & BootSE & BootLLCI & BootULCI \\
\cline { 2 - 7 } & .0000 & .0000 & .0915 & .1413 & -.2051 & .3555 \\
\cline { 2 - 7 } & .0000 & 1.0000 & -.0323 & .0834 & -.2052 & .1383 \\
\cline { 2 - 7 } & 1.0000 & .0000 & -.0241 & .0485 & -.1488 & .0542 \\
\cline { 2 - 7 } & 1.0000 & 1.0000 & .0743 & .0529 & -.0241 & .1857 \\
\hline \multirow{4}{*}{ Bluetooth speakers } & .0000 & .0000 & .1077 & .1640 & -.2278 & .4121 \\
\cline { 2 - 7 } & .0000 & 1.0000 & -.0401 & .1016 & -.2480 & .1544 \\
\cline { 2 - 7 } & 1.0000 & .0000 & -.0375 & .0639 & -.1918 & .0685 \\
\cline { 2 - 7 } & 1.0000 & 1.0000 & .0790 & .0602 & -.0261 & .2101 \\
\hline & .0000 & .0000 & .0971 & .1554 & -.2089 & .4046 \\
\cline { 2 - 7 } & .0000 & 1.0000 & -.0516 & .1284 & -.3064 & .2044 \\
\cline { 2 - 7 } & 1.0000 & .0000 & -.0345 & .0589 & -.1740 & .0643 \\
\cline { 2 - 7 } & 1.0000 & 1.0000 & .0907 & .0561 & -.0257 & .1993 \\
\hline
\end{tabular}

Table 6.5: Study 2 - Moderated mediation - Pleasure factor results 


\begin{tabular}{|c|c|c|c|c|c|c|}
\hline \multicolumn{7}{|c|}{ Conditional Indirect Effects } \\
\hline \multirow{4}{*}{ iPhone cables } & PL Rating & NB Rating & Effect & BootSE & BootLLCI & BootULCI \\
\cline { 2 - 7 } & .0000 & .0000 & .1523 & .1213 & -.0882 & .3934 \\
\cline { 2 - 7 } & .0000 & 1.0000 & .0196 & .0972 & -.1774 & .2153 \\
\cline { 2 - 7 } & 1.0000 & .0000 & -.0203 & .0409 & -.1157 & .0524 \\
\cline { 2 - 7 } & 1.0000 & 1.0000 & .0312 & .0426 & -.0514 & .1276 \\
\hline \multirow{4}{*}{ Bluetooth speakers } & .0000 & .0000 & .1879 & .1459 & -.1011 & .4782 \\
\cline { 2 - 7 } & .0000 & 1.0000 & .0265 & .1286 & -.2354 & .2725 \\
\cline { 2 - 7 } & 1.0000 & .0000 & -.0556 & .0533 & -.1863 & .0241 \\
\cline { 2 - 7 } & 1.0000 & 1.0000 & .1132 & .0717 & -.0167 & .2698 \\
\hline & .0000 & .0000 & .1414 & .1182 & -.0705 & .3924 \\
\cline { 2 - 7 } & .0000 & 1.0000 & .0313 & .1535 & -.2872 & .3258 \\
\cline { 2 - 7 } & 1.0000 & .0000 & -.0455 & .0464 & -.1518 & .0279 \\
\cline { 2 - 7 } & 1.0000 & 1.0000 & .0746 & .0547 & -.0122 & .1964 \\
\hline
\end{tabular}

Table 6.6: Study 2 - Moderated mediation - Arousal factor results

\subsection{Assumption Checks:}

\subsubsection{Section 1: When other brands (NB) ratings are low}

The within-subject factors table (refer to appendix 10) displays that there are three categories and three dependent variables involved in this study. In this study, both PLs (Amazon Basics and DigiShack) and NB's ratings are manipulated and created eight scenarios as mentioned previously.

In the table Between-subject factors (refer to appendix 11), PL represents store brand or private label, and PL rating means the PL brand's rating. PL-0 represents Amazon Basics products, and PL-1 represents DigiShack products. PL Rating-0 represents a low rating, and PL Rating1 represents a high rating.

\begin{tabular}{|c|c|c|c|c|c|c|c|}
\hline \multicolumn{9}{|c|}{ Mauchly's Test of Sphericity } \\
\hline \multicolumn{2}{|c|}{ Measure: MEASURE_1 } \\
\hline $\begin{array}{c}\text { Within } \\
\text { Subjects } \\
\text { Effect }\end{array}$ & Mauchly's W & $\begin{array}{c}\text { Approx. Chi- } \\
\text { Square }\end{array}$ & df & Sig. & $\begin{array}{c}\text { Greenhouse- } \\
\text { Geisser }\end{array}$ & $\begin{array}{c}\text { Huynh- } \\
\text { Feldt }\end{array}$ & $\begin{array}{c}\text { Lower- } \\
\text { bound }\end{array}$ \\
\hline Category & .990 & 1.901 & 2 & .387 & .990 & 1.000 & .500 \\
\hline
\end{tabular}

Table 6.7 - Study 2 - Mauchly's test of sphericity results (a)

Mauchly's test of sphericity (Table 6.7) indicated that the assumption of sphericity had not been violated as the sig. value is higher than .05 . Therefore, I have assumed that there is no deviation of data from sphericity. $x^{2}(2)=1.901, p=.0387$.

There is no significant main effect of category when NB ratings are low, as the sig. value 0.89 , is above the standard cut-off point. That is, there is no effect of product category on the 
product's purchase-likelihood. No significant interaction is found between category and PL, among category and PL Rating, and between PL and PL Rating (refer to appendix 12). F (2, $390)=0.1, p=0.89, \eta p^{2}=.01$

\subsubsection{Section 2: When other brands (NB) ratings are high}

Mauchly's sphericity test (Table 6.8) indicated that sphericity's assumption had been violated as the significance value (.013) is less than the critical value of .05. As sphericity's assumption has been violated, corrections were made based on Greenhouse-Geisser (1959) and Huynh and Feldt (1976). In this case, Greenhouse-Geisser is .953 and is closer to 1. Therefore, it is assumed that data deviation from sphericity is minimal. $x^{2}(2)=8.616, \mathrm{P}=.013$

When NB ratings are high, no significant main effect of a category is found, as the sig. value 0.62 , and above the standard cut-off point. That is, there is no effect of product category on the product's purchase-likelihood. No significant interaction is found between category and PL, among category and PL Rating, and between PL and PL Rating (refer to Table 13). F (2, $388)=2.79, p=0.62, \eta p^{2}=.01$

\begin{tabular}{|c|c|c|c|c|c|c|c|}
\hline \multicolumn{9}{|c|}{ Mauchly's Test of Sphericity $^{\mathrm{a}}$} \\
\hline \multicolumn{2}{|c|}{ Measure: MEASURE_1 } \\
\hline $\begin{array}{c}\text { Within } \\
\text { Subjects } \\
\text { Effect }\end{array}$ & Mauchly's W & $\begin{array}{c}\text { Approx. Chi- } \\
\text { Square }\end{array}$ & df & Sig. & $\begin{array}{c}\text { Greenhouse- } \\
\text { Geisser }\end{array}$ & $\begin{array}{c}\text { Huynh- } \\
\text { Feldt }\end{array}$ & $\begin{array}{c}\text { Lower- } \\
\text { bound }\end{array}$ \\
\hline Category & .956 & 8.616 & 2 & .013 & .958 & .982 & .500 \\
\hline
\end{tabular}

Table 6.8 - Study 2 - Mauchly's test of sphericity results (b)

\subsection{Robustness check:}

\subsubsection{When other brands (NB) ratings are low}

Mauchly's test of sphericity (Table 6.9) indicated that the assumption of sphericity had not been violated as sig. value is $0.35 \cdot x^{2}(2)=2.086, p=.352$. 


\begin{tabular}{|c|c|c|c|c|c|c|c|}
\hline \multicolumn{7}{|c|}{ Mauchly's Test of Sphericity } \\
\hline \multicolumn{2}{|c|}{ Measure: MEASURE_1 } \\
\hline $\begin{array}{c}\text { Within } \\
\text { Subjects } \\
\text { Effect }\end{array}$ & Mauchly's W & $\begin{array}{c}\text { Approx. Chi- } \\
\text { Square }\end{array}$ & df & Sig. & $\begin{array}{c}\text { Greenhouse- } \\
\text { Geisser }\end{array}$ & $\begin{array}{c}\text { Huynh- } \\
\text { Feldt }\end{array}$ & $\begin{array}{c}\text { Lower- } \\
\text { bound }\end{array}$ \\
\hline Category & .977 & 2.086 & 2 & .352 & .978 & 1.000 & .500 \\
\hline
\end{tabular}

Table 6.9 - Study 2 - Mauchly's test of sphericity - Robustness check results (a)

Table 6.10 shows the ANOVA table for the main effect of e-tailer reputation and consumer online ratings. And it reveals a significant effect of PL and PL rating as the sig. values are lower than the standard cut-off point 0.05 . But, no significant interaction is found among PL and PL ratings.

For Amazon Basics PL products, the e-tailer reputation is high $\left(\mathrm{M}_{\text {Amazon_Bascis }}=3.7\right.$ (vs) $M_{\text {DigiShack }}=3.4$ ), which, according to (Hla) should lead to greater purchase intention. Data also supported this statement, as the values are significant $F(1,91)=9.1, p=.003, n p^{2}=.09$.

According to $(\mathrm{H} 4 \mathrm{a})$, when PL online ratings are high, purchase intention should be higher. Data from this section also support this statement, as the values are significant. $F(1,91)=9.5, p=$ $.003, n p^{2}=.09$.

Amazon Basics PL with high online consumer rating, which according to ( $H 5 a$ ) should lead to higher purchase intention. However, data from section 2 do not support this statement, as the values are not significant. $F(1,91)=1.9, p=.161, \eta p^{2}=.02$.

\begin{tabular}{|c|c|c|c|c|c|c|}
\hline \multicolumn{7}{|c|}{ Tests of Between-Subjects Effects } \\
\hline Source & $\begin{array}{c}\text { Type III Sum of } \\
\text { Squares }\end{array}$ & $\mathrm{df}$ & $\begin{array}{c}\text { Mean } \\
\text { Square }\end{array}$ & $\mathrm{F}$ & Sig. & $\begin{array}{c}\text { Partial Eta } \\
\text { squared }\end{array}$ \\
\hline Intercept & 4171.011 & 1 & 4171.011 & 1254.407 & .000 & .932 \\
\hline e-tailer reputation & 30.379 & 1 & 30.379 & 9.136 & .003 & .091 \\
\hline Consumer online rating & 31.627 & 1 & 31.627 & 9.512 & .003 & .095 \\
\hline $\begin{array}{c}\text { e-tailer reputation*Consumer } \\
\text { online rating }\end{array}$ & 6.637 & 1 & 6.637 & 1.996 & .161 & .021 \\
\hline Error & 302.583 & 91 & 3.325 & & & \\
\hline
\end{tabular}

Table 6.10: Study 2 - Test of between subject effects results - Robustness check (a)

\subsubsection{When other brands $(\mathrm{NB})$ ratings are high}

Mauchly's sphericity test (Table 6.11) indicated that sphericity's assumption had been violated as the significance value (.02) is less than the critical value of .05. As sphericity's assumption 
has been violated, corrections are made based on Greenhouse-Geisser (1959) and Huynh and Feldt (1976). In this case, Greenhouse-Geisser is .933 and is closer to 1 . Therefore, we can assume that data deviation from sphericity is minimal. $x^{2}(2)=7.870, p=.02$.

\begin{tabular}{|c|c|c|c|c|c|c|c|}
\hline \multicolumn{9}{|c|}{ Mauchly's Test of Sphericity $^{\text {a }}$} \\
\hline \multicolumn{2}{|c|}{ Measure: MEASURE_1 } \\
\hline $\begin{array}{c}\text { Within } \\
\text { Subjects } \\
\text { Effect }\end{array}$ & Mauchly's W & $\begin{array}{c}\text { Approx. Chi- } \\
\text { Square }\end{array}$ & df & Sig. & $\begin{array}{c}\text { Greenhouse- } \\
\text { Geisser }\end{array}$ & $\begin{array}{c}\text { Huynh- } \\
\text { Feldt }\end{array}$ & $\begin{array}{c}\text { Lower- } \\
\text { bound }\end{array}$ \\
\hline Category & .928 & 7.870 & 2 & .020 & .933 & .976 & .500 \\
\hline
\end{tabular}

Table 6.11 - Study 2 - Mauchly's test of sphericity - Robustness check results (b)

Table 6.12 shows the ANOVA table for the main effect of e-tailer reputation and consumer online ratings. And it reveals a significant effect of PL and PL rating as the sig. values are lower than the standard cut-off point 0.05 . But, no significant interaction is found among PL and PL ratings.

For Amazon Basics PL products, the e-tailer reputation is high $\left(\mathrm{M}_{\text {Amazon_Bascis }}=3.7\right.$ (vs) $\left.M_{\text {Digishack }}=3.4\right)$, which, according to (Hla) should lead to greater purchase intention. Data also supported this statement as the values are significant $F(1,106)=8.0, p=.006, n p^{2}=.07$.

According to $(\mathrm{H} 4 \mathrm{a})$, when PL online ratings are high, purchase intention should be higher. Data from this section also support this statement, as the values are significant. $F(1,106)=14.8, p$ $<.001, n p^{2}=.12$.

Amazon Basics PL with high online consumer rating, which according to ( $H 5 a$ ), should lead to higher purchase intention. However, data from section 2 do not support this statement, as the values are not significant. $F(1,106)=1.5, p=.212, n p^{2}=.01$. 


\begin{tabular}{|c|c|c|c|c|c|c|}
\hline \multicolumn{7}{|c|}{ Tests of Between-Subjects Effects } \\
\hline Source & $\begin{array}{c}\text { Type III Sum of } \\
\text { Squares }\end{array}$ & df & $\begin{array}{c}\text { Mean } \\
\text { Square }\end{array}$ & F & Sig. & $\begin{array}{c}\text { Partial Eta } \\
\text { squared }\end{array}$ \\
\hline Intercept & 3911.143 & 1 & 3911.143 & 1084.475 & .000 & .911 \\
\hline e-tailer reputation & 28.917 & 1 & 28.917 & 8.018 & .006 & .070 \\
\hline Consumer online rating & 53.588 & 1 & 53.588 & 14.859 & .000 & .123 \\
\hline e-tailer reputation*Consumer & 5.694 & 1 & 5.694 & 1.579 & .212 & .015 \\
\hline
\end{tabular}

Table 6.12: Study 2 - Test of between subject effects results - Robustness check (b)

\subsubsection{Binary Logistic Regression:}

To measure accuracy bootstrapping was performed in logistic regression analysis. The upper and lower bound values do not cross zero for the variables that are significant (refer to appendices 17, 18 and 19). Therefore, I can conclude that the results are accurate. From the above results, it is clear that the robustness results are also consistent with previous results.

\section{Chapter 7}

This chapter consists of two sections. Section one focuses on discussing the findings and the conclusions drawn from those findings, followed by the implications for academics, managers, and government. In section two, I discuss the limitations of this research and some suggestions for future research based on this study's findings.

\subsection{Discussion}

\subsubsection{Summary of findings}

The growth of e-commerce has led to the emergence of many online retailers. And, e-tailers are introducing PL brands to achieve different business growth aspects such as increasing revenue and, gaining market share. As such, the understanding of e-tailer PLs and how they impact consumer purchase behaviour can be a substantial benefit to e-tailers and manufacturers. To advance this stream of research, this thesis aims to use factors from existing literature, integrate them with PL factors, and analyse their effects on the purchase likelihood of e-tailer PLs. To achieve these objectives, e-tailer reputation, product manufacturer's country, and online consumer rating factors were examined. 
Table 7.1 reports the summary of accepted and rejected hypotheses based on the results from data analysis.

\begin{tabular}{|c|c|c|c|c|c|c|}
\hline \multicolumn{7}{|c|}{ Experiment 1} \\
\hline & & Purchase- likelihood & & \multicolumn{3}{|c|}{ Actual purchase } \\
\hline & & All Categories & & Category 1 & Category 2 & Category 3 \\
\hline e-tailer reputation & $H 1 a$ & Accepted & $H 1 b$ & Rejected & Rejected & Rejected \\
\hline Manufacturers country & $H 2 a$ & Rejected & $H 2 b$ & Accepted & Accepted & Rejected \\
\hline PL * Country Interaction & $H 3 a$ & Rejected & $H 3 b$ & Rejected & Rejected & Rejected \\
\hline \multicolumn{7}{|c|}{ Experiment 2} \\
\hline \multicolumn{7}{|l|}{ NB ratings are Low } \\
\hline e-tailer reputation & $H 1 a$ & Accepted & $H 1 b$ & Rejected & Rejected & Rejected \\
\hline Online consumer rating & $H 4 a$ & Accepted & $H 4 b$ & Accepted & Accepted & Accepted \\
\hline PL * Rating Interaction & $H 5 a$ & Rejected & $H 5 b$ & Rejected & Rejected & Rejected \\
\hline \multicolumn{7}{|l|}{ NB ratings are High } \\
\hline e-tailer reputation & $H 1 a$ & Accepted & $H 1 b$ & Accepted & Accepted & Rejected \\
\hline Online consumer rating & $H 4 a$ & Accepted & $H 4 b$ & Accepted & Accepted & Accepted \\
\hline PL * Rating Interaction & $H 5 a$ & Rejected & $H 5 b$ & Rejected & Rejected & Rejected \\
\hline
\end{tabular}

Table 7.1: Summary of Hypotheses testing results

\subsection{2 e-Tailer reputation}

The existing literature on brand reputation suggests that retailer reputation (in this case, e-tailer reputation) acts as an extrinsic cue (Woodside, 2012; Herz \& Diamantopoulos 2013) and significantly influences consumer buying behaviour (Akaah \& Korgaonkar, 1988; Tan, 1999).

To understand this effect, I have proposed a relationship between e-tailer reputation and etailer PL, hypothesizing that e-tailer reputation will significantly impact the future purchase intention and actual purchase of e-tailer PLs. And the analysis revealed significant and surprising results, i.e., e-tailer reputation is significantly affecting consumers' future purchase likelihood behaviour (H1a) but has no impact on buying decision or current purchase intentions of e-tailer PLs $(H 1 b)$. This means that when a customer needs a product and visits a website to buy, e-tailer reputation is either not affecting or shows a meagre impact on the customer's purchase intention. On the other hand, when a customer wants to buy a product in the future and is considering options, e-tailer reputation presents a significant impact. Some of the reasons why this situation could arise are possibly because of the domination by other extrinsic cues like product price, after purchase service, higher discount on competitor brands, and availability of better alternative, etc., on consumer purchase intention. Blackwell et al. (2003), 
Hawkins et al. (2003), and Cunningham et al. (2005) described the consumer buying process as a five-stage linear process: need recognition (stage one), information search (stage two), evaluation of alternatives (stage three), buying decision (stage four), and post-purchase behaviour (stage five). The results of this study state that e-tailer reputation can highly impact stage two of the consumer purchase process.

This study's outcomes for purchase intentions are in line with the results from Garrett and Lee, 2017; Wu et al. (2011, p. 36), Diallo (2012), Bao et al. (2011) and, Richardson et al. (1996), whose results reveal that "store image directly affects the purchase intention of PLs." The actual purchase results do not support this statement, as e-tailer reputation does not show any effect on consumer's purchase likelihood. Outcomes of this investigation also supported the statements from: a) Woodside (2012) and Herz and Diamantopoulos (2013) that e-tailer status acts as an extrinsic cue that customers use to evaluate the quality of the product and, b) Kwon (1990) and, Vahie and Paswan (2006) that brands with the superior image are favoured more than brands from a less positive image as the results revealed that Amazon PLs are considered more reputable than DigiShack PLs.

\subsubsection{Product manufacturer's country favourability}

As Herz and Diamantopoulos (2017) mentioned, the country-of-origin effect acts as an extrinsic informational cue while users make product evaluations. Research from Parameswaran and Pisharodi (2002) and Verlegh and Steenkamp (1999) "has shown strong indication that country-of-origin affects product evaluation, which in turn influences purchase intention" (as cited in Garrett \& Lee, 2017, p. 274).

To understand the effect of product manufacturer's country favourability on the purchase intention and actual purchase of PLs, I have proposed a relationship between e-tailer PL and its country of manufacture favourability, hypothesizing that product manufacturer country favourability will significantly impact the purchase intention and actual purchase of e-tailer PLs. Analysis of the data revealed very interesting results: Country favourability can substantially affect the consumer actual purchase intention $H 2 b$ (as two out of three categories showed significant results in binary logistic regression analysis). This effect is consistent with previous literature (Parameswaran \& Pisharodi, 2002; Verlegh \& Steenkamp, 1999). But the results do not show any impact on consumers' future purchase likelihood behaviour (H1b). From the results, I can infer that country favourability can act as a strong extrinsic informational cue in stage four of the buying decision process, which is in line with Herz and 
Diamantopoulos's (2017) statement. Parsons et al. (2012) also found that shoppers are more favourable towards locally made products or products from a culturally close country.

The possible reason why it did not show any effect on future purchases likelihood could be because, while consumers are looking for product alternatives, other extrinsic cues such as brand and price may have shown a more significant effect on consumer future purchase decisions (Garrett \& Lee, 2017; Samiee, 2011).

\subsection{4 e-tailer reputation and country favourability interaction effect}

The above results confirm that e-tailer reputation and country favourability show significant impacts on the e-tailer PL purchase likelihood but at different stages of the consumer buying process. To further understand the extent to which the combined effects of country favourability and e-tailer reputation impact e-tailer PL purchase likelihood. I have hypothesised that the higher the country favourability is, the more significant is the e-tailer reputation effect on the purchase process. Surprisingly, no significant interaction effects are found in future purchase likelihood $H 3 a$ and actual purchase $H 3 b$. The potential reasons for this could be because the e-tailer reputation effect is found in stage two. But the country favourability effect is seen in stage four of the buying decision process.

\subsubsection{Online consumer rating}

As Mudambi and Schuff (2010) stated, online consumer ratings have become a significant source of information for retailers and customers. To understand the effects of online consumer rating on PLs, in this study I have hypothesized that PLs with high consumer rating leads to greater PL purchase likelihood. To clearly understand the effects of consumer ratings, data analysis was performed by separating data based on competitor brand rating i.e. when competitor brand ratings are low and when competitor brand ratings are high.

Results supported both the hypotheses $H 4 a$ and $H 4 b$ as the values are significant in both scenarios (NB rating high and low). This phenomenon clearly says that products with good online consumer ratings will significantly impact the purchase intention and actual purchase of PL products. These findings are consistent with previous research (Filieri et al., 2018; Flanagin et al., 2014; Tran, 2020; Ventre \& Kolbe, 2020). Table 7.2 displays the mean values for both the PL brands. It shows that mean values for brands are higher when their ratings are high, and values are lower when ratings are lower, which evidently displays that consumer ratings influence product reputation and online sales (Dickinger \& Mazanec, 2008). 


\begin{tabular}{|c|c|c|c|c|}
\hline \multirow{2}{*}{ PL } & \multirow{2}{*}{ Rating } & \multicolumn{3}{|c|}{ Mean Values } \\
\cline { 3 - 5 } & & Category 1 & Category 2 & Category 3 \\
\hline \multirow{2}{*}{ Amazon } & Low & 3.88 & 3.56 & 3.56 \\
\cline { 2 - 5 } & High & 3.96 & 4.14 & 4.08 \\
\hline \multirow{2}{*}{ DigiShack } & Low & 3.04 & 3.16 & 3.22 \\
\cline { 2 - 5 } & High & 3.79 & 3.83 & 3.94 \\
\hline
\end{tabular}

Table 7.2 Descriptive Statistics for H4a and H4b.

\subsection{6 e-tailer reputation and online consumer rating interaction effect}

To understand the combined effects of e-tailer reputation and online consumer ratings, I have hypothesized that the more positive or greater the online consumer rating is, the more significant is the impact of e-tailer reputation on the purchase process. But, it is astounding to note that no interaction effect is found between e-tailer reputation and online consumer rating for both purchase likelihood and actual purchase. Therefore, it can be inferred that, irrespective of e-tailer being reputed, products online consumer ratings need to be high and positive to increase the purchase likelihood of e-tailer PL products.

\subsubsection{Competitor brand online ratings: Attenuating effects}

Understanding the effects of high and low online consumer ratings is essential. Similarly, it is also crucial to comprehend how competitor brand ratings (both high rating and low rating) influence the purchase likelihood of e-tailer PLs with high and low online ratings. To investigate this idea, I have theorized that competitor brand ratings will attenuate the effects of e-tailer reputation, online consumer rating H6. The results revealed that whether competitor brand ratings are high or low does not make any difference in the impact of online consumer ratings on PL purchase intention.

\subsubsection{Moderated mediation effects}

This study aims to understand whether the stimuli factors: e-tailer reputation, product country favourability, and online consumer ratings, can draw out shoppers' cognitive and positive affective reactions. However, the results found no support to the statement as the values are not significant. In summary, the factors mentioned above do not moderate or show a negligible effect on generating positive affective reactions.

Bontis et al. (2007, p. 1441) established that "organisational reputation works as a partial mediator for a) customer satisfaction and loyalty and, b) satisfaction and recommendation". 
Research from Kaur et al. (2017) also proved that extrinsic information cues like brand familiarity and vendor offline presence positively influence online shoppers' purchase intention. However, in this study, e-tailer reputation does not show any moderated mediation effect in the purchase likelihood of PL products. Empirical results from Zu et al. (2020) proved that the perceived quality of online reviews does not directly affect consumers' purchase intention. The current research results are consistent with the above study, as no moderated mediation effects are found between online consumer rating and purchase intention.

\subsection{Theoretical Implications}

This research attempts to contribute to the academic literature through its outcomes. The first implication from this research is the addition of knowledge regarding the purchase likelihood of e-tailer PLs. The second contribution from this research is developing a framework to understand the purchase intentions of e-tailer PLs by providing empirical evidence concerning reputation, country favourability, and online consumer ratings. Finally, this research used extrinsic environmental cues in the S-O-R model rather than atmospheric cues. Previous studies have used internal factors like website characteristics to understand the effects on consumer purchase behaviours. But I have considered external extrinsic cues like e-tailer reputation, product manufacturing country favourability, and online consumer rating to comprehend if these factors can affect the purchase likelihood of e-tailer PLs.

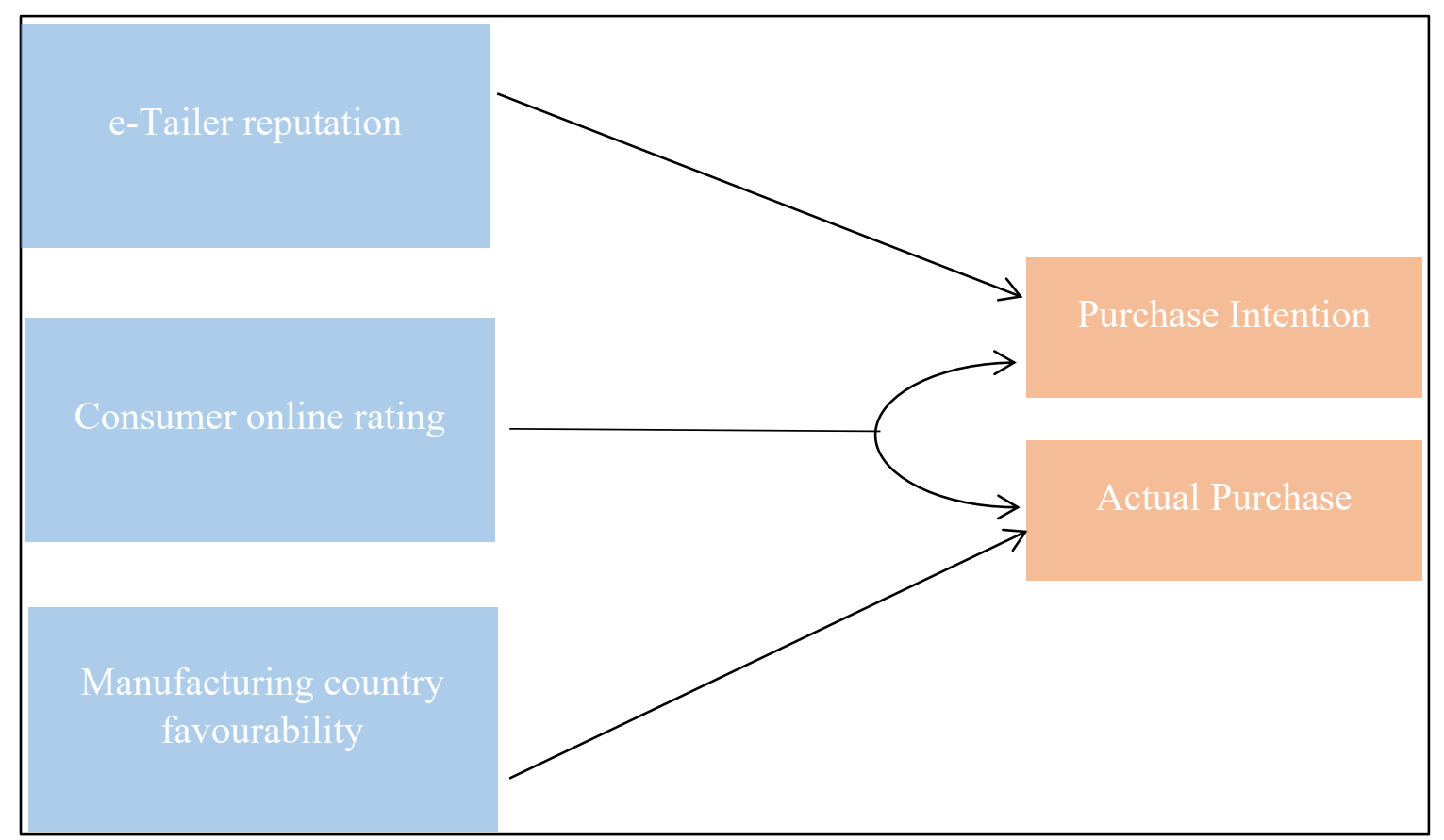

Figure 14: Intention vs Actual purchase of e-tailer PLs 


\subsection{Managerial Implications}

There are three implications for e-tailer management from this study. Firstly, as indicated earlier, e-tailer reputation can significantly influence consumer purchase intention towards etailer PLs. Hence, e-tailers need to spend a considerable amount of time and money improving and maintaining their reputation. New entrants should plan to enhance their offline presence through promotional campaigns in television and outdoor events to build their reputation faster. Secondly, e-tailers should make efforts to produce PLs from a country that is considered favourable in the country of their operations. And, they should develop their website layout in such a way that the PL products country of manufacture is visible to the shoppers, which can act as an extrinsic cue and may motivate shoppers to buy PLs in the electronics category.

Next, most importantly, e-tailers should concentrate on motivating buyers to rate their PL products. This study proved that having a high number of positive ratings can lead to high PL sales. A week or ten days after a PL product is sold and not returned by the customer; the customer service team should contact the buyer (either by call or an e-mail) and take feedback on their product experience. And to encourage shoppers to rate the product on the website, the customer service team should offer a discount coupon or some other promotional perks to the shoppers on their next purchase. Doing this will also help e-tailers understand if there are any drawbacks to the product and improve product features and performance.

\subsection{Implications for public policy}

The government has to introduce a policy that the product description page of the online websites should mandatorily include the place of manufacture and the name of the company that has manufactured the product. Generally retailers don't have manufacturing facilities, they rely on $3^{\text {rd }}$ party manufacturers to produce their products. These manufacturers usually produce products to more than one company to increase their revenues and to utilise maximum capacity of their plant. Sometimes it is possible that the product manufacturer for an established e-tailer and a new entrant could be the same.

Having this information available on the website customers can check:

a) who is manufacturing the product and which country it is manufactured in?

b) if the manufacturer is producing for any other brand?

c) if producing for more than brand, then what is the price difference between those two brands? 
d) if the manufacturer of an established e-tailer is producing for any other new brands?

\subsection{Limitations and future research}

The present study has some limitations. The first limitation is that this study focused only on three categories of the consumer electronics industry. The results cannot be generalised to other categories in the electronics sector and other industries such as fashion or the FMCG industry. This limitation suggests a potential area for future research. A similar study can be conducted in different sectors like consumer FMCG. Vedaka (Amazon PL) and bb royal (Big basket PL) are some of the e-tailer owned brands in the FMCG industry.

Secondly, the collected data were only from US residents. Consumer perceptions and attitudes towards brands and countries may differ from one country to another. So the outcome of this research may not be universal. Another potential research study can be conducted by collecting data from developed and developing countries to compare the consumer behaviour in different countries. Similarly, a combination of countries can also be used to understand the consumers' purchase likelihood factor.

In this study, only product manufacturer's country and online consumer ratings are used in investigating consumer purchase intention. Other extrinsic cues such as product quality and manufacturer warranty can be added to obtain a more comprehensive understanding of shopper behaviour.

Even though I have used a website in this study for the data collection process, it would be more realistic to use the websites owned by the e-tailers. The data collection process should occur realistically rather than selecting an option in a questionnaire. More accurate information can be gathered if respondents are allocated some budget to make them actually buy a product. Finally, it is also essential to understand why e-tailer reputation and country favourability factors affect only certain stages of the consumer purchase process, but not in other stages. 


\section{Appendices}

\section{Appendix 1}

\begin{tabular}{|c|c|}
\hline \multicolumn{2}{|c|}{ Within-Subjects Factors } \\
\hline \multicolumn{2}{|c|}{ Measure: $\quad$ MEASURE_1 } \\
\hline Category & Dependent Variable \\
\hline 1 & Q7_1 \\
\hline 2 & Q9_1 \\
\hline 3 & Q11_1 \\
\hline
\end{tabular}

Appendix 2

\begin{tabular}{|c|c|c|}
\hline \multicolumn{3}{|c|}{ Between-Subjects Factors } \\
\hline & & $\mathrm{N}$ \\
\hline PL & 0 & 130 \\
\hline & 1 & 135 \\
\hline COO & 0 & 129 \\
\hline & 1 & 136 \\
\hline
\end{tabular}

Appendix 3

\begin{tabular}{|c|c|c|c|c|c|c|c|}
\hline \multicolumn{8}{|c|}{ Tests of Within-Subjects Effects } \\
\hline \multicolumn{8}{|c|}{ Measure: MEASURE_1 } \\
\hline \multicolumn{2}{|c|}{ Source } & $\begin{array}{c}\text { Type } \\
\text { III Sum } \\
\text { of }\end{array}$ & $\mathrm{df}$ & $\begin{array}{l}\text { Mean } \\
\text { Square }\end{array}$ & $\mathrm{F}$ & Sig. & $\begin{array}{l}\text { Partial } \\
\text { Eta } \\
\text { Squared }\end{array}$ \\
\hline \multirow{4}{*}{ Category } & $\begin{array}{c}\text { Sphericity } \\
\text { Assumed }\end{array}$ & 2.285 & 2 & 1.143 & 2.984 & .051 & .011 \\
\hline & $\begin{array}{l}\text { Greenhouse- } \\
\text { Geisser }\end{array}$ & 2.285 & 1.907 & 1.199 & 2.984 & .054 & .011 \\
\hline & Huynh-Feldt & 2.285 & 1.943 & 1.176 & 2.984 & .053 & .011 \\
\hline & Lower-bound & 2.285 & 1.000 & 2.285 & 2.984 & .085 & .011 \\
\hline \multirow{4}{*}{ Category * PL } & $\begin{array}{l}\text { Sphericity } \\
\text { Assumed }\end{array}$ & .625 & 2 & .313 & .817 & .442 & .003 \\
\hline & $\begin{array}{l}\text { Greenhouse- } \\
\text { Geisser }\end{array}$ & .625 & 1.907 & .328 & .817 & .437 & .003 \\
\hline & Huynh-Feldt & .625 & 1.943 & .322 & .817 & .439. & .003 \\
\hline & Lower-bound & .625 & 1.000 & .625 & .817 & .367 & .003 \\
\hline \multirow{4}{*}{$\begin{array}{c}\text { Category * } \\
\text { Country }\end{array}$} & $\begin{array}{l}\text { Sphericity } \\
\text { Assumed }\end{array}$ & .788 & 2 & .394 & 1.029 & .358 & .004 \\
\hline & $\begin{array}{l}\text { Greenhouse- } \\
\text { Geisser }\end{array}$ & .788 & 1.907 & .413 & 1.029 & .355 & .004 \\
\hline & Huynh-Feldt & 788 & 1.943 & .406 & 1.029 & .356 & .004 \\
\hline & Lower-bound & 788 & 1.000 & .788 & 1.029 & .311 & .004 \\
\hline
\end{tabular}




\begin{tabular}{|c|c|c|c|c|c|c|c|}
\hline \multirow{4}{*}{$\begin{array}{c}\text { Category * PL } \\
* \text { Country }\end{array}$} & $\begin{array}{c}\text { Sphericity } \\
\text { Assumed }\end{array}$ & .585 & 2 & .293 & .764 & .466 & .003 \\
\cline { 2 - 8 } & $\begin{array}{c}\text { Greenhouse- } \\
\text { Geisser }\end{array}$ & .585 & 1.907 & .307 & .764 & .461 & .003 \\
\cline { 2 - 8 } & Huynh-Feldt & .585 & 1.943 & .301 & .764 & .463 & .003 \\
\cline { 2 - 8 } Error(Category) & Lower-bound & .585 & 1.000 & .585 & .764 & .383 & .003 \\
\hline & $\begin{array}{c}\text { Sphericity } \\
\text { Assumed }\end{array}$ & 199.863 & 522 & .383 & & & \\
\cline { 2 - 9 } & $\begin{array}{c}\text { Greenhouse- } \\
\text { Geisser }\end{array}$ & 199.863 & 497.672 & .402 & & & \\
\cline { 2 - 8 } & Huynh-Feldt & 199.863 & 507.003 & .394 & & & \\
\cline { 2 - 8 } & Lower-bound & 199.863 & 261.000 & .766 & & & \\
\hline
\end{tabular}

\section{Appendix 4}

\begin{tabular}{|c|c|c|c|c|c|c|c|}
\hline \multicolumn{8}{|c|}{ Variables in the Equation } \\
\hline & & B & S.E. & Wald & $\mathrm{df}$ & Sig. & $\operatorname{Exp}(B)$ \\
\hline Step $1^{\mathrm{a}}$ & e-tailer reputation & -.446 & .268 & 2.765 & 1 & .096 & .640 \\
\hline \multirow{2}{*}{$\begin{array}{c}\text { Block } \\
1\end{array}$} & Country favourability & .666 & .271 & 6.045 & 1 & .014 & 1.946 \\
\hline & Constant & -.893 & .238 & 14.030 & 1 & .000 & .409 \\
\hline Step $1^{\mathrm{a}}$ & e-tailer reputation & -.566 & .414 & 1.869 & 1 & .172 & .568 \\
\hline \multirow{3}{*}{$\begin{array}{l}\text { Block } \\
2\end{array}$} & Country favourability & .569 & .369 & 2.382 & 1 & .123 & 1.767 \\
\hline & $\begin{array}{c}\text { e-tailer reputation*country } \\
\text { favourability } \\
\end{array}$ & .207 & .544 & .145 & 1 & .703 & 1.230 \\
\hline & Constant & -.840 & .275 & 9.358 & 1 & .002 & .432 \\
\hline
\end{tabular}

Appendix 5

\begin{tabular}{|c|c|c|c|c|c|c|c|}
\hline \multicolumn{8}{|c|}{ Variables in the Equation } \\
\hline & & B & S.E. & Wald & df & Sig. & $\operatorname{Exp}(B)$ \\
\hline Step $1^{\mathrm{a}}$ & e-tailer reputation & -.529 & .229 & 3.138 & 1 & .077 & .589 \\
\hline \multirow{2}{*}{$\begin{array}{c}\text { Block } \\
1\end{array}$} & Country favourability & .676 & .303 & 4.981 & 1 & .026 & 1.967 \\
\hline & Constant & -1.334 & .267 & 24.914 & 1 & .000 & .263 \\
\hline Step $1^{\mathrm{a}}$ & e-tailer reputation & -.728 & .484 & 2.266 & 1 & .132 & .483 \\
\hline \multirow{3}{*}{$\begin{array}{l}\text { Block } \\
2\end{array}$} & Country favourability & .537 & .399 & 1.809 & 1 & .179 & 1.711 \\
\hline & $\begin{array}{l}\text { e-tailer reputation*country } \\
\text { favourability }\end{array}$ & .326 & .616 & .280 & 1 & .597 & 1.385 \\
\hline & Constant & -1.253 & .303 & 17.089 & 1 & .000 & .286 \\
\hline
\end{tabular}




\section{Appendix 6}

\begin{tabular}{|c|c|c|c|c|c|c|c|}
\hline \multicolumn{8}{|c|}{ Variables in the Equation } \\
\hline & & B & S.E. & Wald & df & Sig. & $\operatorname{Exp}(B)$ \\
\hline Step $1^{\mathrm{a}}$ & e-tailer reputation & -.350 & .274 & 1.633 & 1 & .201 & .705 \\
\hline \multirow{2}{*}{$\begin{array}{c}\text { Block } \\
1\end{array}$} & Country favourability & .372 & .275 & 1.832 & 1 & .176 & 1.451 \\
\hline & Constant & -.938 & .241 & 15.107 & 1 & .000 & .392 \\
\hline Step $1^{\mathrm{a}}$ & e-tailer reputation & -.566 & .414 & 1.869 & 1 & .172 & .568 \\
\hline \multirow{3}{*}{$\begin{array}{c}\text { Block } \\
2\end{array}$} & Country favourability & .191 & .376 & .258 & 1 & .612 & 1.211 \\
\hline & $\begin{array}{l}\text { e-tailer reputation*country } \\
\text { favourability } \\
\end{array}$ & .388 & .553 & .491 & 1 & .483 & 1.473 \\
\hline & Constant & -.840 & .275 & 9.358 & 1 & .002 & .432 \\
\hline
\end{tabular}

Appendix 7

\begin{tabular}{|c|c|c|c|c|c|c|c|}
\hline \multicolumn{8}{|c|}{ Bootstrap for Variables in the Equation } \\
\hline & & \multirow[b]{2}{*}{ B } & \multirow[b]{2}{*}{ Bias } & \multirow[b]{2}{*}{$\begin{array}{l}\text { Std. } \\
\text { Error }\end{array}$} & \multirow{2}{*}{$\begin{array}{c}\text { Bootstrap }^{\text {a }} \\
\text { Sig. (2- } \\
\text { tailed) }\end{array}$} & \multicolumn{2}{|c|}{$\begin{array}{l}\text { 95\% Confidence } \\
\text { Interval }\end{array}$} \\
\hline & & & & & & Lower & Upper \\
\hline Step $1^{\mathrm{a}}$ & e-tailer reputation & -.446 & -.029 & .279 & .112 & -1.030 & .079 \\
\hline \multirow{2}{*}{$\begin{array}{c}\text { Block } \\
1\end{array}$} & $\begin{array}{c}\text { Country } \\
\text { favourability }\end{array}$ & .666 & -.010 & .270 & .015 & .145 & 1.201 \\
\hline & Constant & -.893 & .016 & .242 & .001 & -1.394 & -.429 \\
\hline Step $1^{\mathrm{a}}$ & e-tailer reputation & -.566 & -.018 & .424 & .157 & -1.427 & .223 \\
\hline \multirow{3}{*}{$\begin{array}{l}\text { Block } \\
2\end{array}$} & $\begin{array}{c}\text { Country } \\
\text { favourability }\end{array}$ & .569 & .007 & .380 & .119 & -.155 & 1.362 \\
\hline & $\begin{array}{c}\text { e-tailer } \\
\text { reputation* country } \\
\text { favourability }\end{array}$ & .207 & -.025 & .573 & .716 & -1.009 & 1.344 \\
\hline & Constant & -.840 & .004 & .278 & .002 & -1.438 & -.319 \\
\hline
\end{tabular}

\section{Appendix 8}

\begin{tabular}{|c|c|c|c|c|c|c|c|}
\hline \multicolumn{2}{|c|}{ Bootstrap for Variables in the Equation } \\
\hline & & & & Bootstrap $^{\text {a }}$ & \multicolumn{2}{c|}{$\begin{array}{c}95 \% \text { Confidence } \\
\text { Interval }\end{array}$} \\
\hline \multicolumn{2}{|c|}{} & B & Bias & $\begin{array}{c}\text { Std. } \\
\text { Error }\end{array}$ & $\begin{array}{c}\text { Sig. (2- } \\
\text { tailed) }\end{array}$ & Lower & Upper \\
\hline Step 1 & e-tailer reputation & -.529 & .007 & .296 & .060 & -1.143 & .014 \\
\hline $\begin{array}{c}\text { Block } \\
1\end{array}$ & Country favourability & .676 & .010 & .314 & .023 & .079 & 1.303 \\
\cline { 2 - 8 } & Constant & -1.334 & -.024 & .274 & .001 & -1.927 & -.839 \\
\hline Step 1 & e-tailer reputation & -.728 & -.010 & .521 & .126 & -1.794 & -.264 \\
\hline
\end{tabular}




\begin{tabular}{|c|c|c|c|c|c|c|c|}
\hline \multirow{2}{*}{$\begin{array}{c}\text { Block } \\
2\end{array}$} & Country favourability & .537 & .017 & .421 & .178 & -.226 & 1.392 \\
\cline { 2 - 7 } & $\begin{array}{c}\text { e-tailer } \\
\text { reputation*country } \\
\text { favourability }\end{array}$ & .326 & .014 & .651 & .616 & -.934 & 1.662 \\
\cline { 2 - 8 } & Constant & -1.253 & -.033 & .318 & .001 & -1.963 & -.718 \\
\hline
\end{tabular}

Appendix 9

\begin{tabular}{|c|c|c|c|c|c|c|c|}
\hline \multicolumn{8}{|c|}{ Bootstrap for Variables in the Equation } \\
\hline & & \multirow[b]{2}{*}{$\mathrm{B}$} & \multirow[b]{2}{*}{ Bias } & \multirow[b]{2}{*}{$\begin{array}{l}\text { Std. } \\
\text { Error }\end{array}$} & \multirow{2}{*}{$\begin{array}{c}\text { Bootstrap }^{\mathrm{a}} \\
\begin{array}{c}\text { Sig. }(2- \\
\text { tailed) }\end{array}\end{array}$} & \multicolumn{2}{|c|}{$\begin{array}{l}95 \% \text { Confidence } \\
\text { Interval }\end{array}$} \\
\hline & & & & & & Lower & Upper \\
\hline Step $1^{\mathrm{a}}$ & e-tailer reputation & -.350 & -.001 & .271 & .204 & -.867 & .187 \\
\hline \multirow{2}{*}{$\begin{array}{c}\text { Block } \\
1\end{array}$} & Country favourability & .372 & .018 & .275 & .163 & -.118 & .959 \\
\hline & Constant & -.938 & -.020 & .252 & .001 & -1.493 & -.506 \\
\hline Step $1^{\mathrm{a}}$ & e-tailer reputation & -.566 & -.026 & .416 & .149 & -1.402 & .216 \\
\hline \multirow{3}{*}{$\begin{array}{c}\text { Block } \\
2\end{array}$} & Country favourability & .191 & .004 & .380 & .598 & -.509 & .980 \\
\hline & $\begin{array}{c}\text { e-tailer } \\
\text { reputation*country } \\
\text { favourability }\end{array}$ & .388 & .036 & .563 & .487 & -.740 & 1.539 \\
\hline & Constant & -.840 & -.016 & .285 & .002 & -1.431 & -.361 \\
\hline
\end{tabular}

Appendix 10

\begin{tabular}{|c|c|}
\hline \multicolumn{2}{|c|}{ Within-Subjects Factors } \\
\hline Measure: & MEASURE_1 \\
\hline Category & $\begin{array}{c}\text { Dependent } \\
\text { Variable }\end{array}$ \\
\hline 1 & Q7_1 \\
\hline 2 & Q9_1 \\
\hline 3 & Q11_1 \\
\hline
\end{tabular}

Appendix 11

\begin{tabular}{|c|c|c|}
\hline \multicolumn{3}{|c|}{ Between-Subjects Factors } \\
\hline & & $\mathrm{N}$ \\
\hline PL & 0 & 100 \\
\hline & 1 & 99 \\
\hline PL Rating & 0 & 101 \\
\hline & 1 & 98 \\
\hline
\end{tabular}




\begin{tabular}{|c|c|c|c|c|c|}
\hline \multicolumn{7}{|c|}{ Tests of Within-Subjects Effects } \\
\hline \multicolumn{7}{|c|}{ Measure: } \\
\multicolumn{7}{|c|}{ MEASURE_1 } \\
\hline \multirow{5}{*}{ Source } \\
\cline { 3 - 9 }
\end{tabular}

Appendix13

\begin{tabular}{|c|c|c|c|c|c|c|}
\hline \multicolumn{7}{|c|}{ Tests of Within-Subjects Effects } \\
\hline \multicolumn{7}{|c|}{ Measure: MEASURE_1 } \\
\hline Source & $\begin{array}{c}\text { Type } \\
\text { III Sum } \\
\text { of } \\
\text { Squares }\end{array}$ & $\mathrm{df}$ & $\begin{array}{l}\text { Mean } \\
\text { Square }\end{array}$ & & $\mathrm{Si}$ & $\begin{array}{l}\text { Partial } \\
\text { Eta } \\
\text { Squared }\end{array}$ \\
\hline
\end{tabular}




\begin{tabular}{|c|c|c|c|c|c|c|c|}
\hline \multirow{4}{*}{ Category } & $\begin{array}{l}\text { Sphericity } \\
\text { Assumed }\end{array}$ & 2.566 & 2 & 1.283 & 2.799 & .062 & .014 \\
\hline & $\begin{array}{l}\text { Greenhouse- } \\
\text { Geisser }\end{array}$ & 2.566 & 1.916 & 1.339 & 2.799 & .065 & .014 \\
\hline & Huynh-Feldt & 2.566 & 1.965 & 1.306 & 2.799 & .063 & .014 \\
\hline & Lower-bound & 2.566 & 1.000 & 2.566 & 2.799 & .096 & .014 \\
\hline \multirow{4}{*}{ Category * PL } & $\begin{array}{l}\text { Sphericity } \\
\text { Assumed }\end{array}$ & .182 & 2 & .091 & .199 & .820 & .001 \\
\hline & $\begin{array}{l}\text { Greenhouse- } \\
\text { Geisser }\end{array}$ & .182 & 1.916 & .095 & .199 & .811 & .001 \\
\hline & Huynh-Feldt & .182 & 1.965 & .093 & .199 & .816 & .001 \\
\hline & Lower-bound & .182 & 1.000 & .182 & .199 & .656 & .001 \\
\hline \multirow{4}{*}{$\begin{array}{c}\text { Category } * \text { PL } \\
\text { Rating }\end{array}$} & $\begin{array}{l}\text { Sphericity } \\
\text { Assumed }\end{array}$ & .577 & 2 & .289 & .630 & .533 & .003 \\
\hline & $\begin{array}{l}\text { Greenhouse- } \\
\text { Geisser }\end{array}$ & .577 & 1.916 & .301 & .630 & .527 & .003 \\
\hline & Huynh-Feldt & .577 & 1.965 & .294 & .630 & .530 & .003 \\
\hline & Lower-bound & .577 & 1.000 & .577 & .630 & .428 & .003 \\
\hline \multirow{4}{*}{$\begin{array}{c}\text { Category * PL } \\
\text { * PL Rating }\end{array}$} & $\begin{array}{l}\text { Sphericity } \\
\text { Assumed }\end{array}$ & .838 & 2 & .419 & .914 & .402 & .005 \\
\hline & $\begin{array}{l}\text { Greenhouse- } \\
\text { Geisser }\end{array}$ & .838 & 1.916 & .437 & .914 & .398 & .005 \\
\hline & Huynh-Feldt & .838 & 1.965 & .426 & .914 & .400 & .005 \\
\hline & Lower-bound & .838 & 1.000 & .838 & .914 & .340 & .005 \\
\hline \multirow{4}{*}{ Error(Category) } & $\begin{array}{l}\text { Sphericity } \\
\text { Assumed }\end{array}$ & 177.851 & 388 & .458 & & & \\
\hline & $\begin{array}{l}\text { Greenhouse- } \\
\text { Geisser }\end{array}$ & 177.851 & 371.769 & .478 & & & \\
\hline & Huynh-Feldt & 177.851 & 381.200 & .467 & & & \\
\hline & Lower-bound & 177.851 & 194.000 & .917 & & & \\
\hline
\end{tabular}

\section{Appendix 14}

\begin{tabular}{|c|c|c|c|c|c|c|c|c|}
\hline \multicolumn{9}{|c|}{ Variables in the equation } \\
\hline \multicolumn{3}{|r|}{ Other Brands Rating } & $\mathrm{B}$ & S.E. & Wald & $\mathrm{df}$ & Sig. & $\operatorname{Exp}(B)$ \\
\hline 0 & $\begin{array}{c}\text { Step } \\
1^{\mathrm{a}}\end{array}$ & e-tailer reputation & -.378 & .313 & 1.461 & 1 & .227 & .685 \\
\hline \multirow{2}{*}{\multicolumn{2}{|c|}{ Block 1}} & Consumer online rating & .977 & .317 & 9.513 & 1 & .002 & 2.655 \\
\hline & & Constant & $1 . \overline{-}$ & .280 & 15.361 & 1 & $<.001$ & .334 \\
\hline 1 & $\begin{array}{c}\text { Step } \\
1^{\mathrm{a}} \\
\end{array}$ & e-tailer reputation & $\begin{array}{c}- \\
1.051 \\
\end{array}$ & .395 & 7.062 & 1 & .008 & .350 \\
\hline \multirow{2}{*}{\multicolumn{2}{|c|}{ Block 1}} & Consumer online rating & 1.478 & .420 & 12.396 & 1 & $<.001$ & 4.385 \\
\hline & & Constant & $1 . \overline{876}$ & .372 & 25.415 & 1 & $<.001$ & .153 \\
\hline 0 & $\begin{array}{l}\text { Step } \\
1^{\mathrm{a}}\end{array}$ & e-tailer reputation & -.991 & .511 & 3.765 & 1 & .052 & .371 \\
\hline \multirow{3}{*}{\multicolumn{2}{|c|}{ Block 2}} & Consumer online rating & .525 & .421 & 1.551 & 1 & .213 & 1.690 \\
\hline & & $\begin{array}{c}\text { e-tailer reputation by Consumer online } \\
\text { rating }\end{array}$ & 1.026 & .653 & 2.470 & 1 & .116 & 2.790 \\
\hline & & Constant & -.847 & .309 & 7.538 & 1 & .006 & .429 \\
\hline
\end{tabular}




\begin{tabular}{|c|c|c|c|c|c|c|c|c|}
\hline 1 & $\begin{array}{c}\text { Step } \\
1^{\mathrm{a}}\end{array}$ & e-tailer reputation & - & 1.082 & 4.277 & 1 & .039 & .107 \\
\hline \multirow{3}{*}{ Block 2 } & Consumer online rating & 1.113 & .483 & 5.309 & 1 & .021 & 3.043 \\
\cline { 2 - 8 } & $\begin{array}{c}\text { e-tailer reputation by Consumer online } \\
\text { rating }\end{array}$ & 1.493 & 1.171 & 1.626 & 1 & .202 & 4.449 \\
\cline { 2 - 9 } & Constant & $\begin{array}{c}- \\
1.634\end{array}$ & .387 & 17.875 & 1 & $<.001$ & .195 \\
\hline
\end{tabular}

Appendix 15

\begin{tabular}{|c|c|c|c|c|c|c|c|c|}
\hline \multicolumn{9}{|c|}{ Variables in the equation } \\
\hline \multicolumn{3}{|r|}{ Other Brands Rating } & B & S.E. & Wald & df & Sig. & $\operatorname{Exp}(B)$ \\
\hline 0 & $\begin{array}{c}\text { Step } \\
1^{\mathrm{a}}\end{array}$ & e-tailer reputation & -.871 & .336 & 6.718 & 1 & .010 & .419 \\
\hline \multirow{2}{*}{\multicolumn{2}{|c|}{ Block 1}} & Consumer online rating & 1.721 & .348 & 24.524 & 1 & $<.001$ & 5.590 \\
\hline & & Constant & $1 . \overline{295}$ & .301 & 18.520 & 1 & $<.001$ & .274 \\
\hline 1 & $\begin{array}{l}\text { Step } \\
1^{\mathrm{a}}\end{array}$ & e-tailer reputation & $\begin{array}{c}- \\
1.471\end{array}$ & .536 & 7.520 & 1 & .006 & .230 \\
\hline \multirow{2}{*}{\multicolumn{2}{|c|}{ Block 1}} & Consumer online rating & 1.427 & .537 & 7.059 & 1 & .008 & 4.165 \\
\hline & & Constant & $2 . \overline{398}$ & .478 & 25.223 & 1 & $<.001$ & .091 \\
\hline 0 & $\begin{array}{c}\text { Step } \\
1^{\mathrm{a}}\end{array}$ & e-tailer reputation & $\overline{-}$ & .617 & 4.513 & 1 & .034 & .270 \\
\hline \multirow{3}{*}{\multicolumn{2}{|c|}{ Block 2}} & Consumer online rating & 1.475 & .438 & 11.353 & 1 & $<.001$ & 4.373 \\
\hline & & $\begin{array}{c}\text { e-tailer reputation by Consumer online } \\
\text { rating }\end{array}$ & .652 & .741 & .775 & 1 & .379 & 1.919 \\
\hline & & Constant & $\begin{array}{c}- \\
1.153\end{array}$ & .331 & 12.117 & 1 & $<.001$ & .316 \\
\hline 1 & $\begin{array}{c}\text { Step } \\
1^{\mathrm{a}}\end{array}$ & e-tailer reputation & $\overline{-}$ & 1.137 & 1.678 & 1 & .195 & .229 \\
\hline \multirow{3}{*}{\multicolumn{2}{|c|}{ Block 2}} & Consumer online rating & 1.426 & .609 & 5.479 & 1 & .019 & 4.162 \\
\hline & & $\begin{array}{c}\text { e-tailer reputation by Consumer online } \\
\text { rating }\end{array}$ & .003 & 1.290 & .000 & 1 & .998 & 1.003 \\
\hline & & Constant & $2 . \overline{-}$ & .522 & 21.083 & 1 & $<.001$ & .091 \\
\hline
\end{tabular}

Appendix 16

\begin{tabular}{|c|c|c|c|c|c|c|c|c|}
\hline \multicolumn{9}{|c|}{ Variables in the equation } \\
\hline \multicolumn{3}{|c|}{ Other Brands Rating } & B & S.E. & Wald & df & Sig. & $\operatorname{Exp}(B)$ \\
\hline 0 & $\begin{array}{c}\text { Step } \\
1^{\mathrm{a}}\end{array}$ & e-tailer reputation & -.358 & .316 & 1.281 & 1 & .258 & .699 \\
\hline \multirow{2}{*}{\multicolumn{2}{|c|}{ Block 1}} & Consumer online rating & 1.362 & .322 & 17.839 & 1 & $<.001$ & 3.903 \\
\hline & & Constant & ${ }^{-} \overline{228}$ & .288 & 18.173 & 1 & $<.001$ & .293 \\
\hline 1 & $\begin{array}{c}\text { Step } \\
1^{\mathrm{a}}\end{array}$ & e-tailer reputation & $\begin{array}{c}- \\
1.300\end{array}$ & .471 & 7.619 & 1 & .006 & .273 \\
\hline \multicolumn{2}{|c|}{ Block 1} & Consumer online ratin & 1.254 & .472 & 7.075 & 1 & .008 & 3.505 \\
\hline
\end{tabular}




\begin{tabular}{|c|c|c|c|c|c|c|c|c|}
\hline & & Constant & 2.071 & .414 & 25.048 & 1 & $<.001$ & .126 \\
\hline 0 & $\begin{array}{l}\text { Step } \\
1^{\mathrm{a}}\end{array}$ & e-tailer reputation & -.792 & .519 & 2.329 & 1 & .127 & .453 \\
\hline \multirow{3}{*}{\multicolumn{2}{|c|}{ Block 2}} & Consumer online rating & 1.046 & .429 & 5.948 & 1 & .015 & 2.846 \\
\hline & & $\begin{array}{c}\text { e-tailer reputation by Consumer online } \\
\text { rating }\end{array}$ & .709 & .658 & 1.161 & 1 & .281 & 2.032 \\
\hline & & Constant & 1.046 & .322 & 10.525 & 1 & .001 & .351 \\
\hline 1 & $\begin{array}{l}\text { Step } \\
1^{\mathrm{a}}\end{array}$ & e-tailer reputation & $\begin{array}{c}- \\
1.925\end{array}$ & 1.101 & 3.060 & 1 & .080 & .146 \\
\hline \multirow{3}{*}{\multicolumn{2}{|c|}{ Block 2}} & Consumer online rating & 1.070 & .534 & 4.022 & 1 & .045 & 2.917 \\
\hline & & $\begin{array}{l}\text { e-tailer reputation by Consumer online } \\
\text { rating }\end{array}$ & .808 & 1.223 & .437 & 1 & .509 & 2.244 \\
\hline & & Constant & 1.946 & .436 & 19.879 & 1 & $<.001$ & .143 \\
\hline
\end{tabular}

Appendix 17

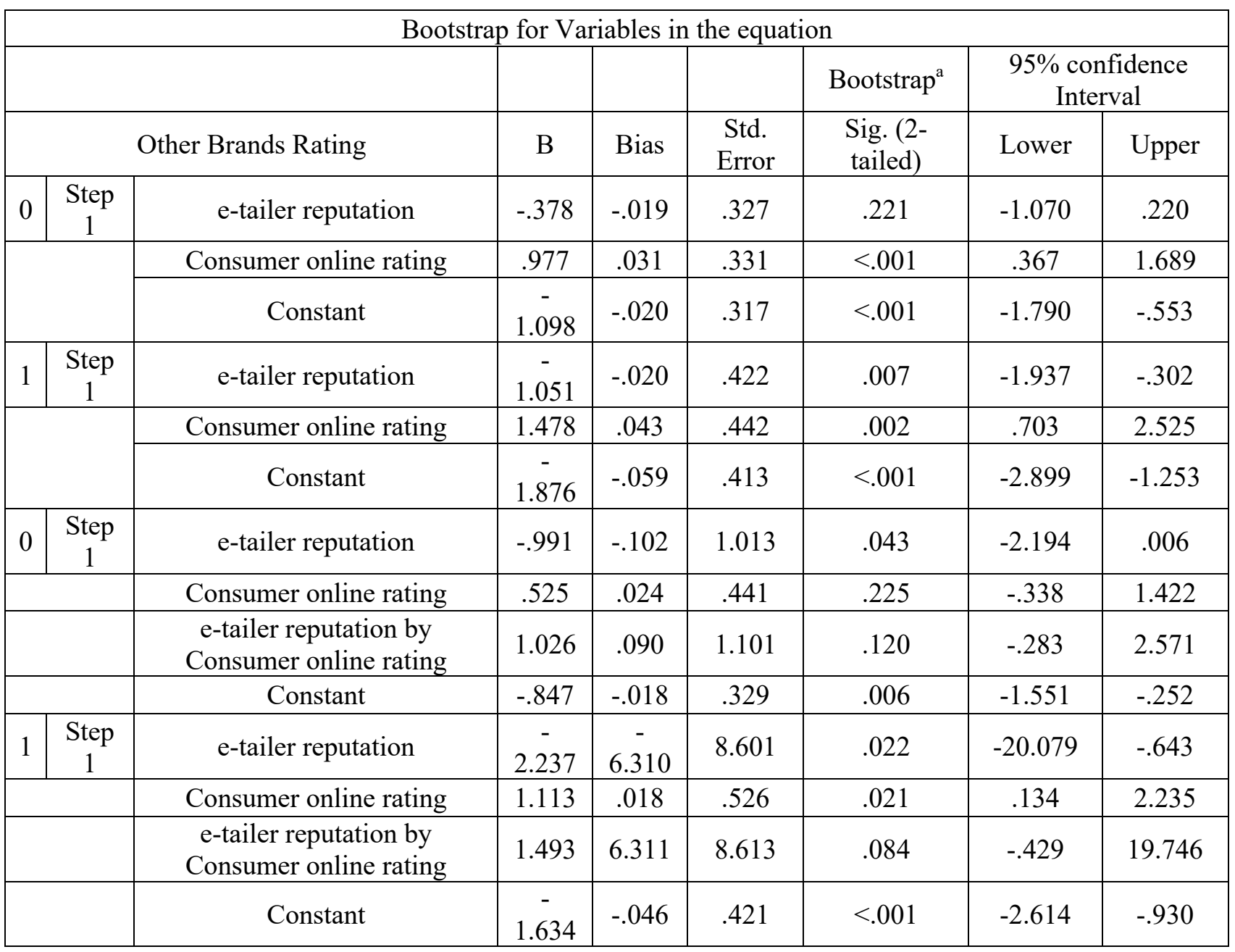




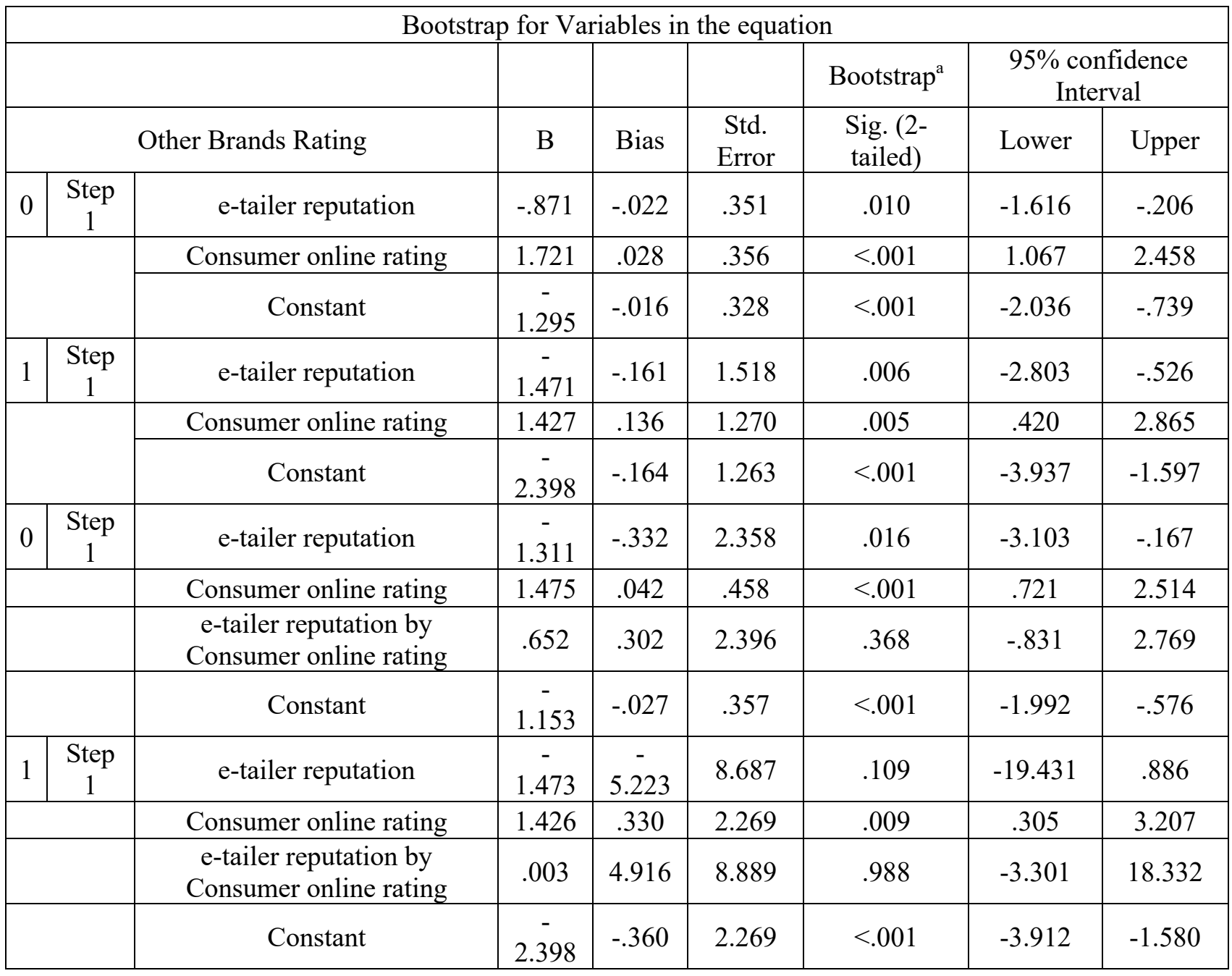

Appendix 19

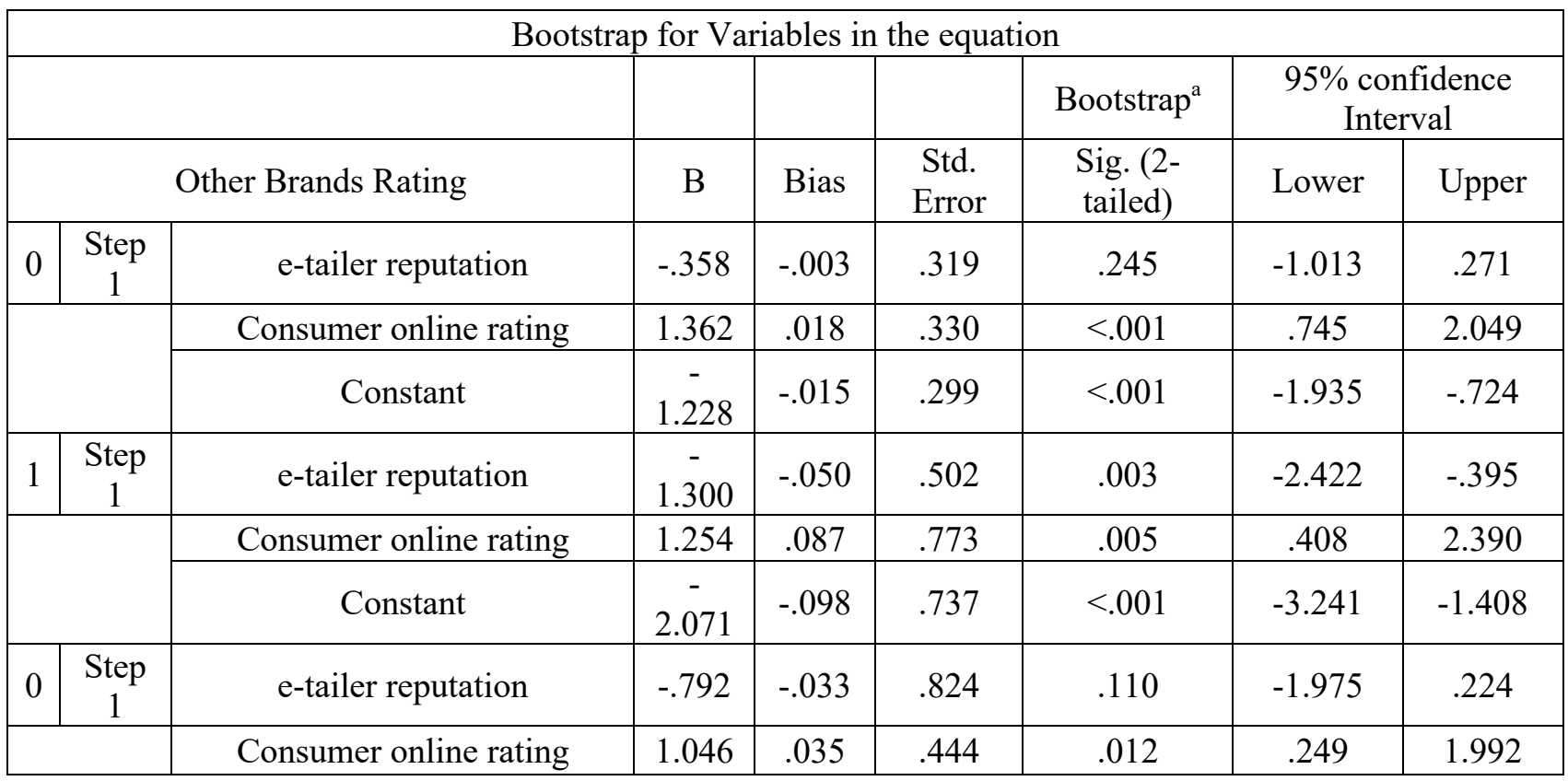




\begin{tabular}{|c|c|c|c|c|c|c|c|c|}
\hline & $\begin{array}{l}\text { e-tailer reputation by } \\
\text { Consumer online rating }\end{array}$ & .709 & .020 & .922 & .289 & -.540 & 2.195 \\
\hline & & Constant & $1 . \overline{-}$ & -.027 & .327 & $<.001$ & -1.792 & -.490 \\
\hline \multirow[t]{4}{*}{1} & $\begin{array}{c}\text { Step } \\
1\end{array}$ & e-tailer reputation & $\begin{array}{c}- \\
1.925\end{array}$ & $\begin{array}{c}- \\
6.285\end{array}$ & 8.698 & .051 & -19.868 & -.121 \\
\hline & & Consumer online rating & 1.070 & .105 & 1.058 & .035 & .085 & 2.408 \\
\hline & & $\begin{array}{l}\text { e-tailer reputation by } \\
\text { Consumer online rating }\end{array}$ & .808 & 6.175 & 8.853 & .277 & -1.367 & 19.125 \\
\hline & & Constant & 1946 & -.123 & .985 & $<.001$ & -3.219 & -1.240 \\
\hline
\end{tabular}

Appendix 20

\begin{tabular}{|c|c|c|c|c|c|}
\hline \multicolumn{7}{|c|}{ Conditional Indirect effects } \\
\hline \multirow{2}{*}{ iPhone cables } & Country & Effect & BootSE & BootLLCI & BootULCI \\
\cline { 2 - 6 } & .0000 & -.0659 & .0592 & -.2086 & .0271 \\
\cline { 2 - 6 } & 1.0000 & -.0522 & .0794 & -.2126 & .1034 \\
\hline \multirow{2}{*}{ Bluetooth speakers } & .0000 & -.1029 & .0799 & -.2766 & .0417 \\
\cline { 2 - 6 } & 1.0000 & -.0522 & .0799 & -.2156 & .0999 \\
\hline \multirow{2}{*}{ Universal adapters } & .0000 & -.0917 & .0782 & -.2672 & .0363 \\
\cline { 2 - 6 } & 1.0000 & -.0470 & .0739 & -.2090 & .0875 \\
\hline
\end{tabular}

Appendix 21

\begin{tabular}{|c|c|c|c|c|c|}
\hline \multicolumn{7}{|c|}{ Conditional Indirect effects } \\
\hline \multirow{3}{*}{ iPhone cables } & Country & Effect & BootSE & BootLLCI & BootULCI \\
\cline { 2 - 6 } & .0000 & -.0201 & .0683 & -.1683 & .1045 \\
\cline { 2 - 6 } & 1.0000 & -.0274 & .0628 & -.1591 & .0915 \\
\hline \multirow{2}{*}{ Bluetooth speakers } & .0000 & -.0220 & .0741 & -.1825 & .1125 \\
\cline { 2 - 6 } & 1.0000 & -.0311 & .0717 & -.1798 & .1092 \\
\hline \multirow{2}{*}{ Universal adapters } & .0000 & -.0241 & .0811 & -.2020 & .1264 \\
\cline { 2 - 6 } & 1.0000 & -.0336 & .0773 & -.2034 & .1108 \\
\hline
\end{tabular}

Appendix 22

\begin{tabular}{|l|l|l|l|l|}
\hline \multicolumn{5}{|c|}{ Independent T-Test Group Statistics } \\
\hline & $\mathrm{N}$ & Mean & Std. Deviation & Std. Error Mean \\
\hline Amazon Basics & 130 & 5.92 & 1.07 & .094 \\
\hline DigiShack & 135 & 5.45 & 1.27 & .110 \\
\hline
\end{tabular}




\begin{tabular}{|c|c|c|c|c|c|c|c|c|c|}
\hline \multicolumn{10}{|c|}{ Independent Samples Test } \\
\hline & $\mathrm{F}$ & Sig. & $\mathrm{t}$ & $\mathrm{df}$ & $\begin{array}{c}\text { Sig(2- } \\
\text { tailed) }\end{array}$ & $\begin{array}{c}\text { Mean } \\
\text { difference }\end{array}$ & $\begin{array}{c}\text { Std. Error } \\
\text { Difference }\end{array}$ & \multicolumn{2}{c|}{$\begin{array}{c}95 \% \\
\text { confidence }\end{array}$} \\
\cline { 5 - 10 } & & & & Lower & Upper \\
\hline $\begin{array}{c}\text { Equal variances } \\
\text { assumed }\end{array}$ & 9.67 & .002 & 3.20 & 263 & .002 & .464 & .145 & .178 & .749 \\
\hline $\begin{array}{c}\text { Equal variances } \\
\text { not assumed }\end{array}$ & & & 3.21 & 258.35 & .001 & .464 & .144 & .179 & .748 \\
\hline
\end{tabular}

Appendix 24

\begin{tabular}{|c|c|c|c|}
\hline \multicolumn{4}{|c|}{ Paired Samples Statistics } \\
\hline & Mean & Std. Deviation & Std. Error Mean \\
\hline Mexico & 5.37 & 1.362 & .084 \\
\hline China & 4.76 & 1.863 & .114 \\
\hline \multicolumn{4}{|c|}{ Paired Samples Correlations } \\
\hline & $\mathrm{N}$ & Correlation & Sig. \\
\hline Mexico \& China & 265 & .313 & .000 \\
\hline
\end{tabular}

Appendix 25

\begin{tabular}{|c|c|c|c|c|c|c|c|c|}
\hline \multicolumn{9}{|c|}{ Paired Samples Test } \\
\hline & \multirow[t]{2}{*}{ Mean } & \multirow{2}{*}{$\begin{array}{c}\text { Std. } \\
\text { Deviation }\end{array}$} & \multirow{2}{*}{$\begin{array}{l}\text { Std. Error } \\
\text { Mean }\end{array}$} & \multicolumn{2}{|c|}{$\begin{array}{l}95 \% \text { confidence } \\
\text { interval }\end{array}$} & \multirow[t]{2}{*}{$\mathrm{t}$} & \multirow[t]{2}{*}{ df } & \multirow{2}{*}{$\begin{array}{l}\operatorname{Sig}(2 \\
\text { tailed }\end{array}$} \\
\hline & & & & Lower & Upper & & & \\
\hline China \& Mexico & .611 & 1.934 & .119 & 263 & .002 & .464 & .145 & .178 \\
\hline
\end{tabular}

Appendix 26

\begin{tabular}{|c|c|c|c|c|}
\hline \multicolumn{5}{|c|}{ Independent T-Test Group Statistics } \\
\hline & $\mathrm{N}$ & Mean & Std. Deviation & Std. Error Mean \\
\hline Amazon Basics & 199 & 5.95 & 1.001 & .071 \\
\hline DigiShack & 197 & 5.38 & 1.499 & .107 \\
\hline
\end{tabular}

Appendix 27

\begin{tabular}{|c|c|c|c|c|c|c|c|c|c|}
\hline \multicolumn{10}{|c|}{ Independent Samples Test } \\
\hline & \multirow[t]{2}{*}{$\mathrm{F}$} & \multirow[t]{2}{*}{ Sig. } & \multirow[t]{2}{*}{$\mathrm{t}$} & \multirow[t]{2}{*}{ df } & \multirow{2}{*}{$\begin{array}{l}\operatorname{Sig}(2- \\
\text { tailed })\end{array}$} & \multirow{2}{*}{$\begin{array}{c}\text { Mean } \\
\text { difference }\end{array}$} & \multirow{2}{*}{$\begin{array}{l}\text { Std. Error } \\
\text { Difference }\end{array}$} & \multicolumn{2}{|c|}{$\begin{array}{c}95 \% \\
\text { confidence }\end{array}$} \\
\hline & & & & & & & & Lower & Upper \\
\hline $\begin{array}{c}\text { Equal } \\
\text { variances } \\
\text { assumed }\end{array}$ & 31.47 & .000 & 4.52 & 394 & .000 & .579 & .128 & .328 & .831 \\
\hline $\begin{array}{c}\text { Equal } \\
\text { variances not } \\
\text { assumed } \\
\end{array}$ & & & 4.51 & 341.53 & .000 & .579 & .128 & .327 & .831 \\
\hline
\end{tabular}




\begin{tabular}{|c|c|c|c|}
\hline \multicolumn{4}{|c|}{ Independent T-Test Group Statistics } \\
\hline & Mean & Std. Deviation & Std. Error Mean \\
\hline PL rating low & 3.53 & 1.190 & .085 \\
\hline PL rating high & 3.97 & .948 & .067 \\
\hline Anker rating low & 3.55 & 1.071 & .074 \\
\hline Anker rating high & 3.93 & .886 & 0.63 \\
\hline Belkin rating low & 3.75 & 1.043 & .074 \\
\hline Belkin rating high & 4.05 & .835 & .059 \\
\hline Epicka rating low & 3.43 & 1.139 & .081 \\
\hline Epicka rating high & 3.86 & .877 & .063 \\
\hline JBL rating low & 3.71 & 1.082 & .077 \\
\hline JBL rating high & 4.09 & .884 & .063 \\
\hline Oontz rating low & 3.34 & 1.184 & .084 \\
\hline Oontz rating high & 3.76 & .971 & .069 \\
\hline Xcentz rating low & 3.46 & 1.186 & .084 \\
\hline Xcentz rating high & 3.82 & .945 & .068 \\
\hline
\end{tabular}

Appendix 29

\begin{tabular}{|c|c|c|c|c|c|c|c|c|c|}
\hline \multicolumn{10}{|c|}{ Independent Samples Test } \\
\hline & \multirow[t]{2}{*}{$\mathrm{F}$} & \multirow[t]{2}{*}{ Sig. } & \multirow[t]{2}{*}{ t } & \multirow[t]{2}{*}{$\mathrm{df}$} & \multirow{2}{*}{$\begin{array}{l}\operatorname{Sig}(2- \\
\text { tailed })\end{array}$} & \multirow{2}{*}{$\begin{array}{c}\text { Mean } \\
\text { difference }\end{array}$} & \multirow{2}{*}{$\begin{array}{l}\text { Std. Error } \\
\text { Difference }\end{array}$} & \multicolumn{2}{|c|}{$\begin{array}{c}95 \% \\
\text { confidence }\end{array}$} \\
\hline & & & & & & & & Lower & Upper \\
\hline $\begin{array}{c}\text { Equal } \\
\text { variances } \\
\text { assumed }\end{array}$ & 25.02 & .000 & -4.11 & 391 & .000 & -.447 & .108 & -.660 & -.233 \\
\hline $\begin{array}{c}\text { Equal } \\
\text { variances not } \\
\text { assumed }\end{array}$ & & & -4.11 & 369.92 & .000 & -.447 & 108 & -.660 & -.233 \\
\hline $\begin{array}{c}\text { Equal } \\
\text { variances } \\
\text { assumed }\end{array}$ & 16.95 & .000 & -3.78 & 391 & .000 & -.375 & .099 & -.570 & -.180 \\
\hline $\begin{array}{c}\text { Equal } \\
\text { variances not } \\
\text { assumed }\end{array}$ & & & -3.78 & 378.41 & .000 & -.375 & .099 & -.570 & -.180 \\
\hline $\begin{array}{c}\text { Equal } \\
\text { variances } \\
\text { assumed }\end{array}$ & 16.23 & .000 & -3.14 & 392 & .002 & -.299 & .095 & -.487 & -.112 \\
\hline $\begin{array}{c}\text { Equal } \\
\text { variances not } \\
\text { assumed }\end{array}$ & & & -3.14 & 374.01 & .002 & -.299 & .095 & -.487 & -.112 \\
\hline $\begin{array}{c}\text { Equal } \\
\text { variances } \\
\text { assumed }\end{array}$ & 23.97 & .000 & -4.19 & 391 & .000 & -.431 & .103 & -.632 & -.229 \\
\hline $\begin{array}{c}\text { Equal } \\
\text { variances not } \\
\text { assumed }\end{array}$ & & & -4.20 & 367.92 & .000 & -.431 & .103 & -.632 & -.229 \\
\hline $\begin{array}{c}\text { Equal } \\
\text { variances } \\
\text { assumed }\end{array}$ & 14.28 & .000 & -3.81 & 392 & .000 & -.380 & .100 & -.576 & -.184 \\
\hline
\end{tabular}




\begin{tabular}{|c|l|l|l|l|l|l|l|l|l|}
\hline $\begin{array}{c}\text { Equal } \\
\text { variances not } \\
\text { assumed }\end{array}$ & & -3.81 & 378.41 & .000 & -.380 & .099 & -.575 & -.184 \\
\hline $\begin{array}{c}\text { Equal } \\
\text { variances } \\
\text { assumed }\end{array}$ & 13.08 & .000 & -3.86 & 392 & .000 & -.422 & .109 & -.636 & -.207 \\
\hline $\begin{array}{c}\text { Equal } \\
\text { variances not } \\
\text { assumed }\end{array}$ & 21.93 & .000 & -3.28 & 391 & .001 & -.356 & .108 & -.569 & -.143 \\
\hline $\begin{array}{c}\text { Equal } \\
\text { variances } \\
\text { assumed }\end{array}$ & -3.86 & 378.83 & .000 & -.422 & .109 & -.636 & -.207 \\
\hline $\begin{array}{c}\text { Equal } \\
\text { variances not } \\
\text { assumed }\end{array}$ & & -3.29 & 374.75 & .001 & -.356 & .108 & -.568 & -.143 \\
\hline
\end{tabular}




\section{Study 1: Questionnaire}

Are you currently using an iPhone?

Yes

No

Do you reside in USA?

Yes

No

Please indicate your ethnicity:

Caucasian White

African American

American Indian

European (Western)

European (Eastern)

Hispanic/Latino

Asian

Others (Please specify)

Prefer not to say

Please read the following information carefully before answering the following questions.

Imagine you're going on a vacation and you have realized that you need to buy a few items online.

For choosing a product, please click on the given hyperlinks which will prompt you to a product page from where you have to choose a product. 
Block 1:

Please click on the hyperlink below and decide which product you would prefer to purchase, then select it from the list below.

https://storebrandz.myshopify.com/admin/themes/104982904995/editor\#/collections/store-brand-1

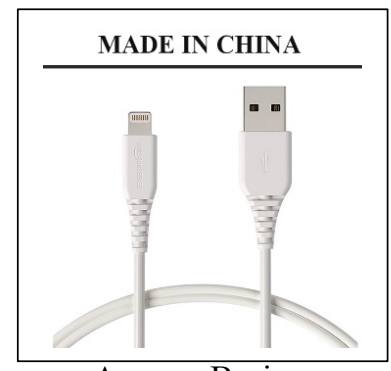

AmazonBasics

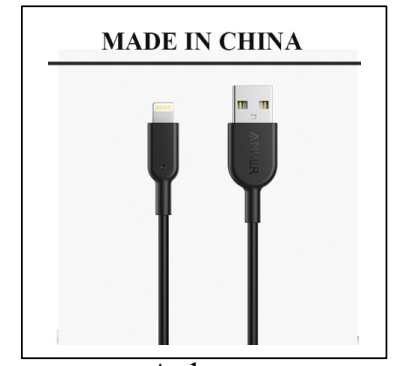

Anker

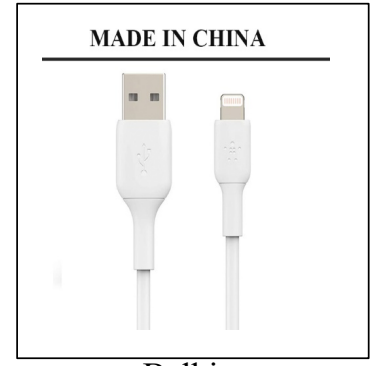

Belkin

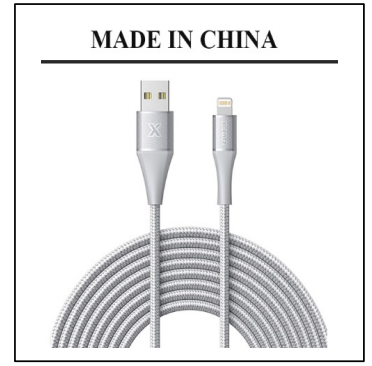

Xcentz

How likely are you to purchase the following brands the next time you consider purchasing an iPhone cable?

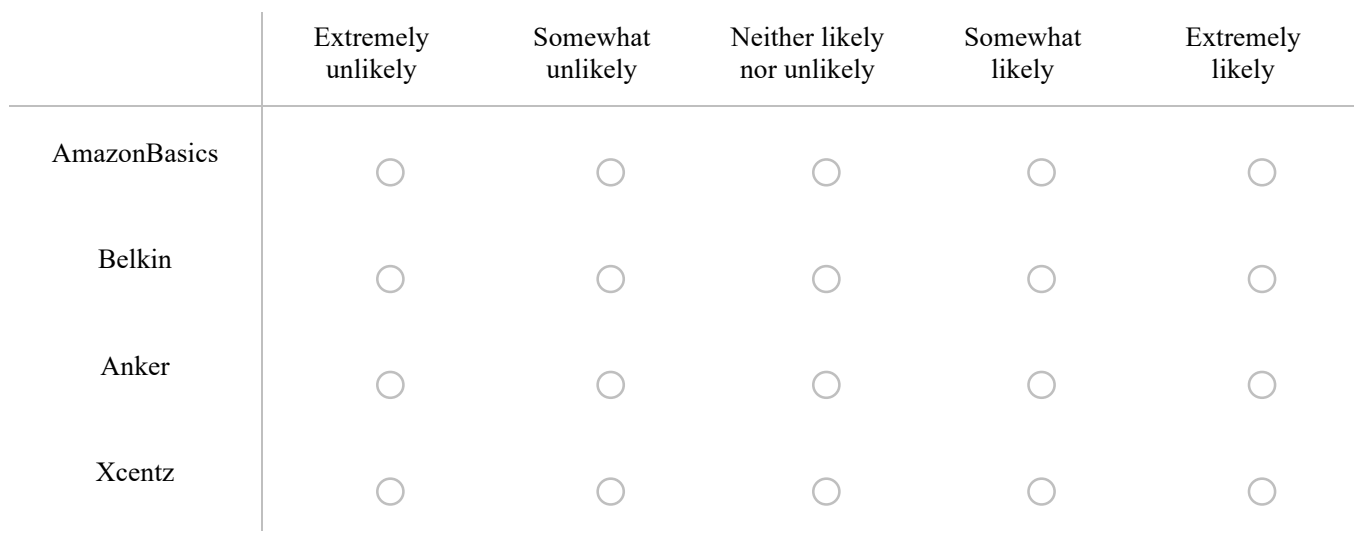

Please click on the hyperlink below and which product you would prefer to purchase, then select it from the list below https://storebrandz.myshopify.com/admin/themes/104982904995/editor\#/collections/store-brand-2

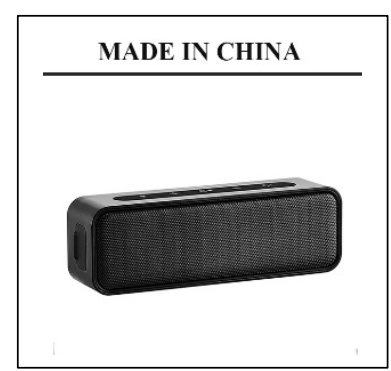

AmazonBasics

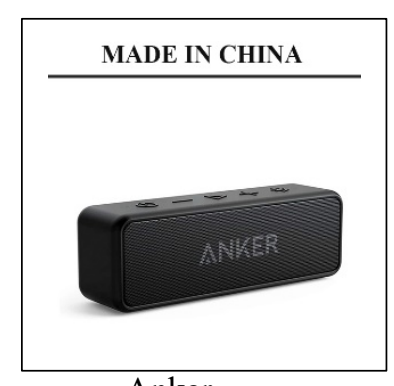

Anker

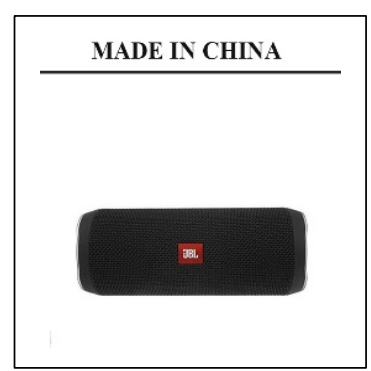

JBL

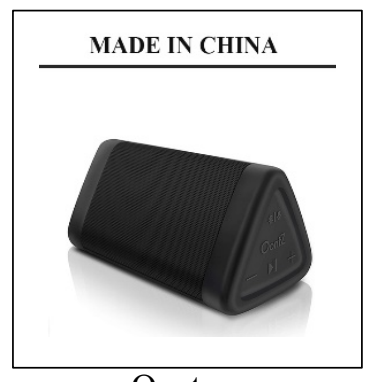

Oontz 
How likely are you to purchase the following brands the next time you consider purchasing a Bluetooth speaker?

\begin{tabular}{c|ccccc} 
& Extremely unlikely & Somewhat unlikely & $\begin{array}{c}\text { Neither likely nor } \\
\text { unlikely }\end{array}$ & Somewhat likely & Extremely likely \\
\hline $\begin{array}{c}\text { AmazonBasics } \\
\text { Bluetooth speaker }\end{array}$ & 0 & 0 & 0 & \\
$\begin{array}{c}\text { JBL Flip Bluetooth } \\
\text { speaker }\end{array}$ & 0 & 0 & 0 & 0 \\
$\begin{array}{c}\text { Oontz Bluetooth } \\
\text { speaker }\end{array}$ & 0 & 0 & 0 & 0 & 0 \\
$\begin{array}{c}\text { Anker Bluetooth } \\
\text { speaker }\end{array}$ & 0 & 0 & 0 & 0 &
\end{tabular}

Please click on the hyperlink below and decide which product you would prefer to purchase, then select it from the list below.

https://storebrandz.myshopify.com/admin/themes/104982904995/editor\#/collections/storebrandz-3

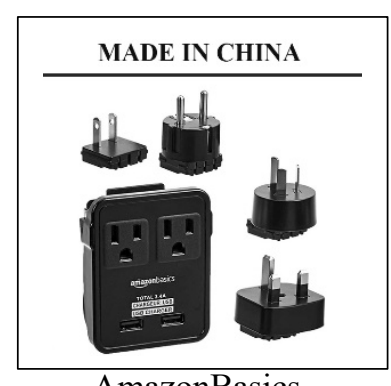

AmazonBasics

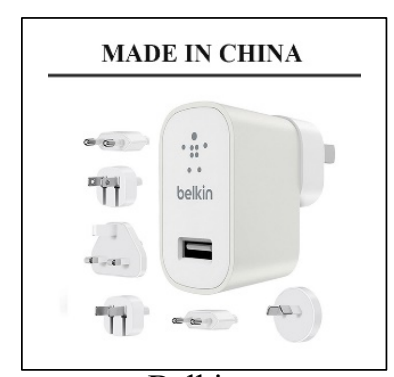

Belkin

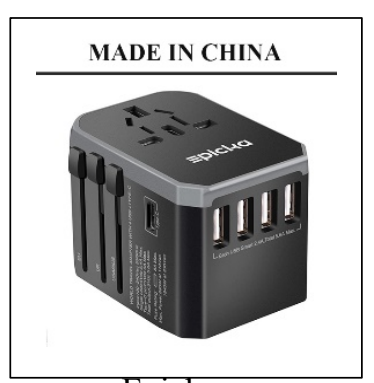

Epicka

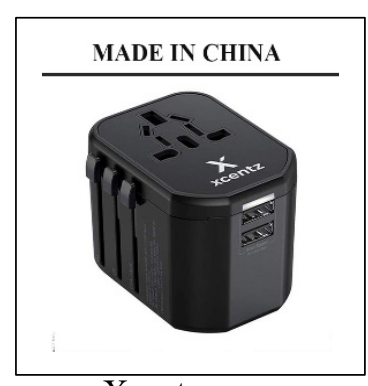

Xcentz

How likely are you to purchase the following brands the next time you consider purchasing a Universal travel adapter?

\begin{tabular}{c|ccccc} 
& Extremely unlikely & Somewhat unlikely & $\begin{array}{c}\text { Neither likely nor } \\
\text { unlikely }\end{array}$ & Somewhat likely & Extremely likely \\
\hline $\begin{array}{c}\text { AmazonBasics } \\
\text { universal charger }\end{array}$ & 0 & 0 & 0 & 0 \\
$\begin{array}{c}\text { Belkin universal } \\
\text { charger }\end{array}$ & 0 & 0 & 0 & 0 \\
$\begin{array}{c}\text { Xcentz universal } \\
\text { charger }\end{array}$ & 0 & 0 & 0 & 0 \\
$\begin{array}{c}\text { Epicka universal } \\
\text { charger }\end{array}$ & 0 & 0 & 0 & 0
\end{tabular}


Indicate the extent to which you agree with the following statement.

\begin{tabular}{c|ccccccc} 
& $\begin{array}{c}\text { Strongly } \\
\text { disagree }\end{array}$ & Disagree & $\begin{array}{c}\text { Somewhat } \\
\text { disagree }\end{array}$ & $\begin{array}{c}\text { Neither } \\
\text { agree nor } \\
\text { disagree }\end{array}$ & $\begin{array}{c}\text { Somewhat } \\
\text { agree }\end{array}$ & Agree & $\begin{array}{c}\text { Strongly } \\
\text { agree }\end{array}$ \\
\hline $\begin{array}{c}\text { Amazon is } \\
\text { an e- } \\
\text { retailer } \\
\text { with good } \\
\text { reputation }\end{array}$ & 0 & 0 & 0 & 0 & 0 & 0 & \\
& & & & &
\end{tabular}

Block 2:

Please click on the hyperlink below and decide which product you would prefer to purchase, then select it from the list below.

https://storebrandz.myshopify.com/admin/themes/104982904995/editor\#/collections/amazon-1

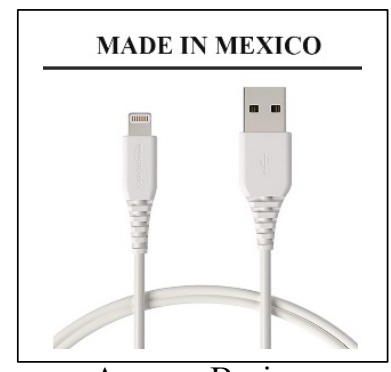

AmazonBasics

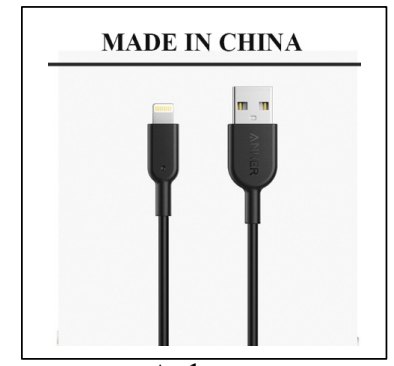

Anker

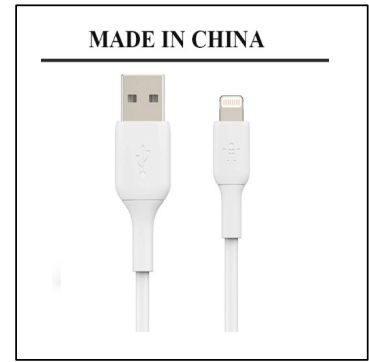

Belkin

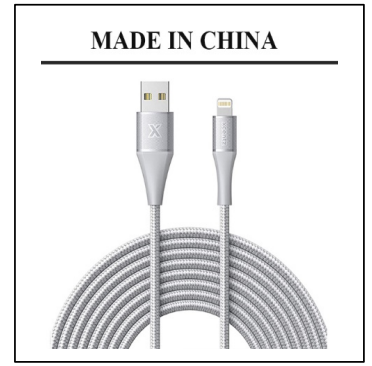

Xcentz

How likely are you to purchase the following brands the next time you consider purchasing an iPhone cable?

\begin{tabular}{c|ccccc} 
& Extremely unlikely & Somewhat unlikely & $\begin{array}{c}\text { Neither likely nor } \\
\text { unlikely }\end{array}$ & Somewhat likely & Extremely likely \\
\hline $\begin{array}{c}\text { Amazon Basics } \\
\text { iPhone cable }\end{array}$ & 0 & 0 & 0 & \\
$\begin{array}{c}\text { Belkin lightning } \\
\text { iPhone cable }\end{array}$ & 0 & 0 & 0 & \\
$\begin{array}{c}\text { Anker lightning } \\
\text { iPhone cable }\end{array}$ & 0 & 0 & 0 & \\
$\begin{array}{c}\text { Xcentz lightning } \\
\text { iPhone cable }\end{array}$ & & & & & \\
& & & &
\end{tabular}


Please click on the hyperlink below and decide which product you would prefer to purchase, then select it from the list below.

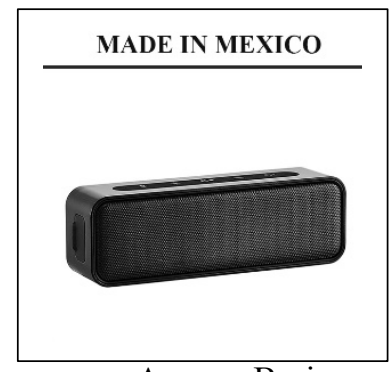

AmazonBasics

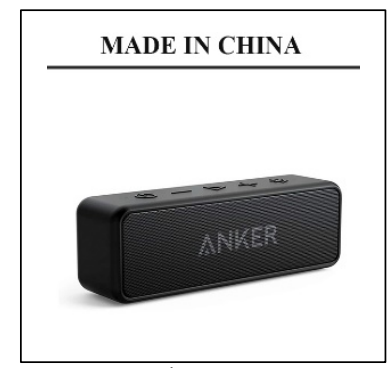

Anker

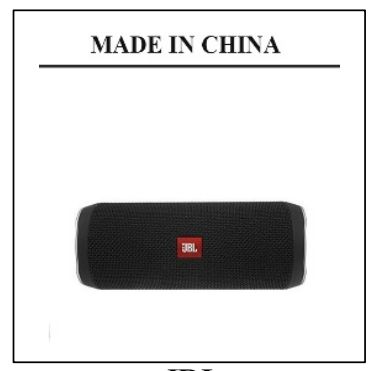

JBL

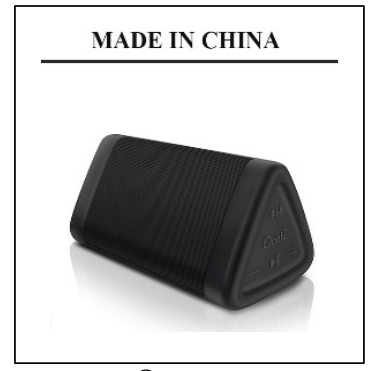

Oontz

How likely are you to purchase the following brands the next time you consider purchasing a Bluetooth speaker?

\begin{tabular}{|c|c|c|c|c|c|}
\hline & Extremely unlikely & Somewhat unlikely & $\begin{array}{l}\text { Neither likely nor } \\
\text { unlikely }\end{array}$ & Somewhat likely & Extremely likely \\
\hline $\begin{array}{l}\text { AmazonBasics } \\
\text { Bluetooth speaker }\end{array}$ & $\bigcirc$ & $\bigcirc$ & $\bigcirc$ & $\bigcirc$ & $\bigcirc$ \\
\hline $\begin{array}{l}\text { JBL Flip Bluetooth } \\
\text { speaker }\end{array}$ & $\bigcirc$ & $\bigcirc$ & $\bigcirc$ & $\bigcirc$ & $\bigcirc$ \\
\hline $\begin{array}{l}\text { Oontz Bluetooth } \\
\text { speaker }\end{array}$ & $\bigcirc$ & $\bigcirc$ & $\bigcirc$ & $\bigcirc$ & $\bigcirc$ \\
\hline $\begin{array}{l}\text { Anker Bluetooth } \\
\text { speaker }\end{array}$ & $\bigcirc$ & ○ & $\bigcirc$ & $\bigcirc$ & $\bigcirc$ \\
\hline
\end{tabular}

Please click on the hyperlink below and decide which product you would prefer to purchase, then select it from the list. below. https://storebrandz.myshopify.com/admin/themes/104982904995/editor\#/collections/amazon-3

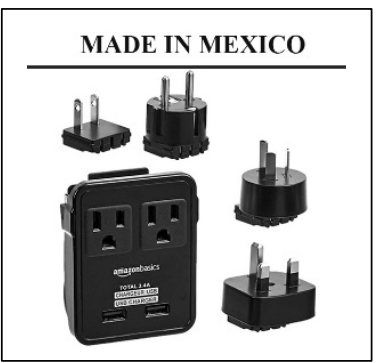

AmazonBasics

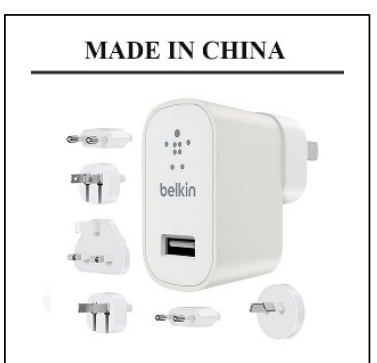

Belkin

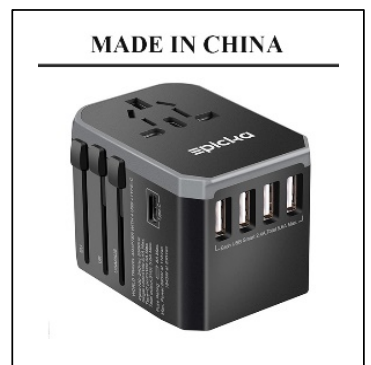

Epicka

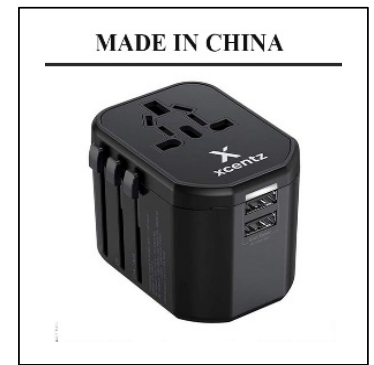

Xcentz 
How likely are you to purchase the following brands the next time you consider purchasing a Universal travel adapter?

\begin{tabular}{c|ccccc} 
& Extremely unlikely & Somewhat unlikely & $\begin{array}{c}\text { Neither likely nor } \\
\text { unlikely }\end{array}$ & Somewhat likely & Extremely likely \\
\hline $\begin{array}{c}\text { AmazonBasics } \\
\text { universal charger }\end{array}$ & 0 & 0 & 0 & 0 \\
$\begin{array}{c}\text { Belkin universal } \\
\text { charger }\end{array}$ & 0 & 0 & 0 & 0 \\
$\begin{array}{c}\text { Xentz universal } \\
\text { charger }\end{array}$ & 0 & &
\end{tabular}

Indicate the extent to which you agree with the following statement.

\begin{tabular}{c|ccccccc} 
& $\begin{array}{c}\text { Strongly } \\
\text { disagree }\end{array}$ & Disagree & $\begin{array}{c}\text { Somewhat } \\
\text { disagree }\end{array}$ & $\begin{array}{c}\text { Neither agree } \\
\text { nor disagree }\end{array}$ & $\begin{array}{c}\text { Somewhat } \\
\text { agree }\end{array}$ & $\begin{array}{c}\text { Agree } \\
\text { agree }\end{array}$ \\
\hline $\begin{array}{c}\text { Amazon is an } \\
\text { e-retailer with } \\
\text { good } \\
\text { reputation }\end{array}$ & 0 & 0 & 0 & 0 & 0 & \\
\end{tabular}

\section{Block 3:}

Please click on the hyperlink below and decide which product you would prefer to purchase, then select it from the list below.

https://storebrandz.myshopify.com/admin/themes/104982904995/editor\#/collections/sb-cables-china

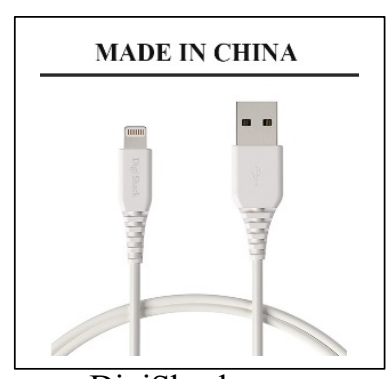

DigiShack

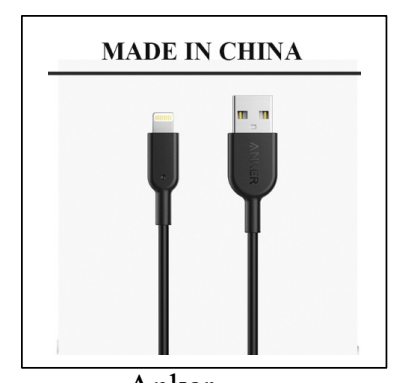

Anker

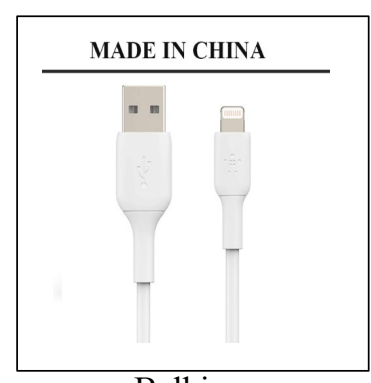

Belkin

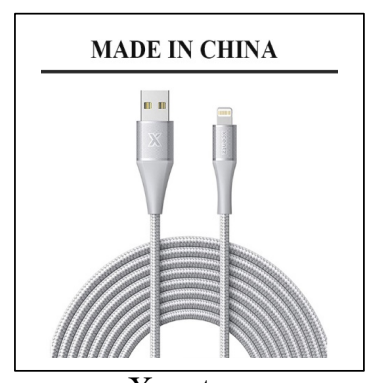

Xcentz 
How likely are you to purchase the following brands the next time you consider purchasing an iPhone cable?

\begin{tabular}{|c|c|c|c|c|c|}
\hline & Extremely unlikely & Somewhat unlikely & $\begin{array}{l}\text { Neither likely nor } \\
\text { unlikely }\end{array}$ & Somewhat likely & Extremely likely \\
\hline $\begin{array}{l}\text { DigiShack iPhone } \\
\text { cable }\end{array}$ & $\bigcirc$ & $\bigcirc$ & $\bigcirc$ & $\bigcirc$ & $\bigcirc$ \\
\hline $\begin{array}{l}\text { Belkin lightning } \\
\text { iPhone cable }\end{array}$ & $\bigcirc$ & $\bigcirc$ & $\bigcirc$ & $\bigcirc$ & $\bigcirc$ \\
\hline $\begin{array}{l}\text { Anker lightning } \\
\text { iPhone cable }\end{array}$ & O & $\bigcirc$ & $\bigcirc$ & $\bigcirc$ & $\bigcirc$ \\
\hline $\begin{array}{l}\text { Xcentz lightning } \\
\text { iPhone cable }\end{array}$ & 0 & $\bigcirc$ & $\bigcirc$ & $\bigcirc$ & $\bigcirc$ \\
\hline
\end{tabular}

Please click on the hyperlink below and decide which product you would prefer to purchase, then select it from the list below.

https://storebrandz.myshopify.com/admin/themes/104982904995/editor\#/collections/sb-speakers-china

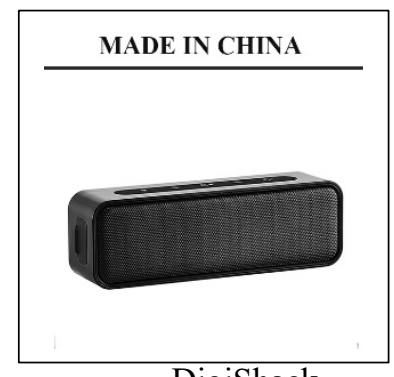

DigiShack

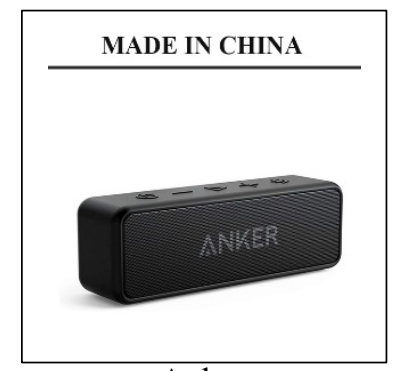

Anker

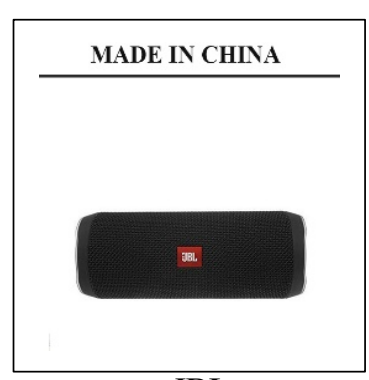

JBL

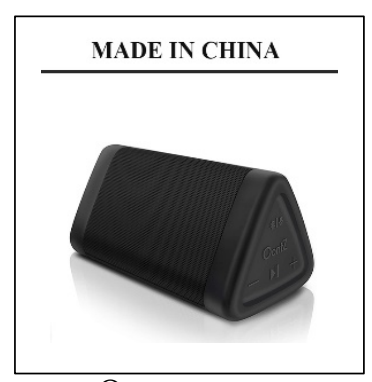

Oontz

How likely are you to purchase the following brands the next time you consider purchasing a Bluetooth speaker?

\begin{tabular}{|c|c|c|c|c|c|}
\hline & Extremely unlikely & $\begin{array}{l}\text { Somewhat } \\
\text { unlikely }\end{array}$ & $\begin{array}{l}\text { Neither likely nor } \\
\text { unlikely }\end{array}$ & Somewhat likely & Extremely likely \\
\hline $\begin{array}{c}\text { DigiShack } \\
\text { Bluetooth speaker }\end{array}$ & $\bigcirc$ & $\bigcirc$ & $\bigcirc$ & $\bigcirc$ & $\bigcirc$ \\
\hline $\begin{array}{l}\text { JBL Flip Bluetooth } \\
\text { speaker }\end{array}$ & $\bigcirc$ & $\bigcirc$ & O & O & ○ \\
\hline $\begin{array}{l}\text { Oontz Bluetooth } \\
\text { speaker }\end{array}$ & $\bigcirc$ & $\bigcirc$ & $\bigcirc$ & $\bigcirc$ & $\bigcirc$ \\
\hline $\begin{array}{l}\text { Anker Bluetooth } \\
\text { speaker }\end{array}$ & $\bigcirc$ & $\bigcirc$ & $\bigcirc$ & $\bigcirc$ & $\bigcirc$ \\
\hline
\end{tabular}


Please click on the hyperlink below and decide which product you would prefer to purchase, then select it from the list below.

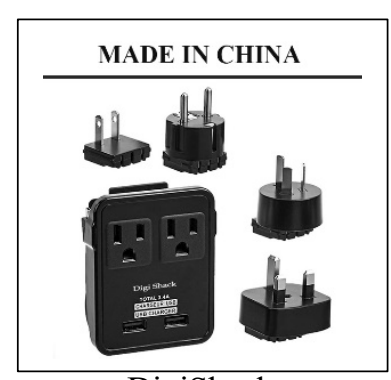

DigiShack

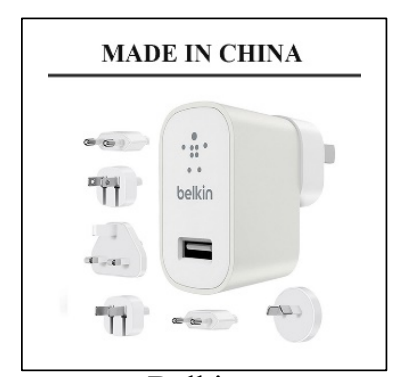

Belkin

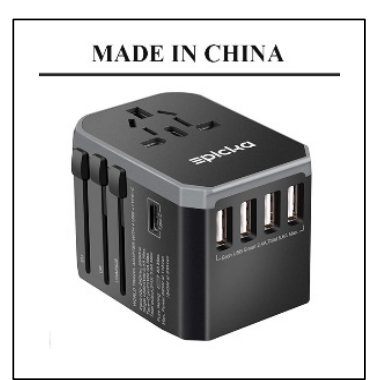

Epicka

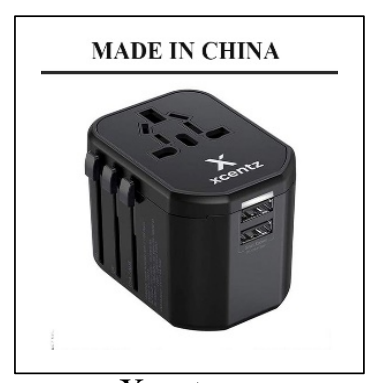

Xcentz

How likely are you to purchase the following brands the next time you consider purchasing a Universal travel adapter?

\begin{tabular}{c|ccccc} 
& Extremely unlikely & Somewhat unlikely & $\begin{array}{c}\text { Neither likely nor } \\
\text { unlikely }\end{array}$ & Somewhat likely & Extremely likely \\
\hline $\begin{array}{c}\text { DigiShack } \\
\text { universal charger }\end{array}$ & 0 & 0 & 0 & & \\
$\begin{array}{c}\text { Belkin universal } \\
\text { charger }\end{array}$ & 0 & 0 & 0 & 0 \\
$\begin{array}{c}\text { Xcentz universal } \\
\text { charger }\end{array}$ & 0 & 0 & 0 & 0 & 0 \\
$\begin{array}{c}\text { Epicka universal } \\
\text { charger }\end{array}$ & 0 & 0 & 0 & 0 & 0 \\
& & & &
\end{tabular}

Indicate the extent to which you agree with the following statements.

\begin{tabular}{c|ccccccc} 
& $\begin{array}{c}\text { Strongly } \\
\text { disagree }\end{array}$ & Disagree & $\begin{array}{c}\text { Somewhat } \\
\text { disagree }\end{array}$ & $\begin{array}{c}\text { Neither } \\
\text { agree nor } \\
\text { disagree }\end{array}$ & $\begin{array}{c}\text { Somewhat } \\
\text { agree }\end{array}$ & Agree & $\begin{array}{c}\text { Strongly } \\
\text { agree }\end{array}$ \\
\hline $\begin{array}{c}\text { DigiShack } \\
\text { is an e- } \\
\text { retailer } \\
\text { with good } \\
\text { reputation }\end{array}$ & 0 & 0 & 0 & 0 & 0 & 0 & \\
\end{tabular}

Block 4:

Please click on the hyperlink below and decide which product you would prefer to purchase, then select it from the list below.

https://storebrandz.myshopify.com/admin/themes/104982904995/editor\#/collections/sb-cables-mexico 


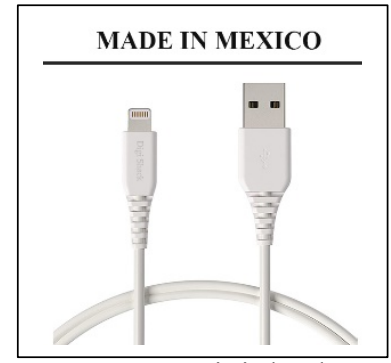

DigiShack

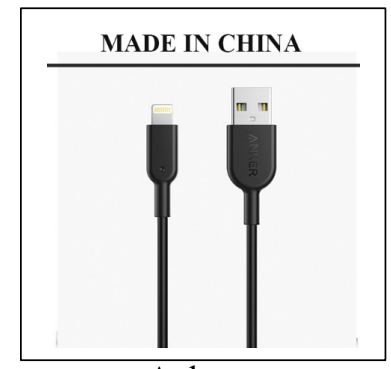

Anker

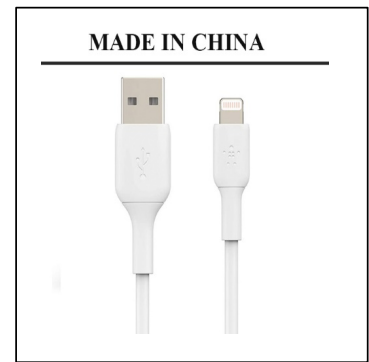

Belkin

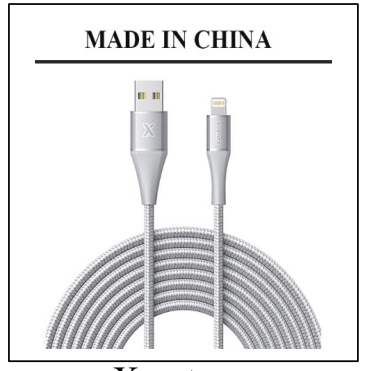

Xcentz

How likely are you to purchase the following brands the next time you consider purchasing an iPhone cable?

\begin{tabular}{c|ccccc} 
& Extremely unlikely & Somewhat unlikely & $\begin{array}{c}\text { Neither likely nor } \\
\text { unlikely }\end{array}$ & Somewhat likely & Extremely likely \\
\hline $\begin{array}{c}\text { DigiShack iPhone } \\
\text { cable }\end{array}$ & 0 & 0 & & \\
$\begin{array}{c}\text { Belkin lightning } \\
\text { iPhone cable }\end{array}$ & 0 & 0 & 0 & \\
$\begin{array}{c}\text { Anker lightning } \\
\text { iPhone cable }\end{array}$ & 0 & 0 & & \\
$\begin{array}{c}\text { Xcentz lightning } \\
\text { iPhone cable }\end{array}$ & 0 & 0 & 0 & 0 & \\
& & & &
\end{tabular}

Please click on the hyperlink below and decide which product you would prefer to purchase, then select it from the list below.

https://storebrandz.myshopify.com/admin/themes/104982904995/editor\#/collections/sb-speakers-mexico

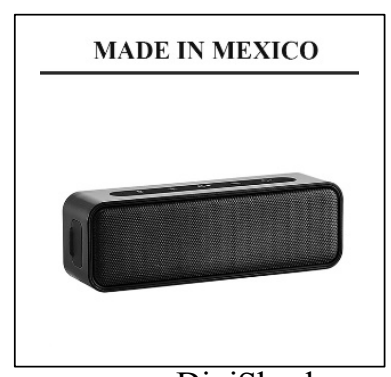

DigiShack

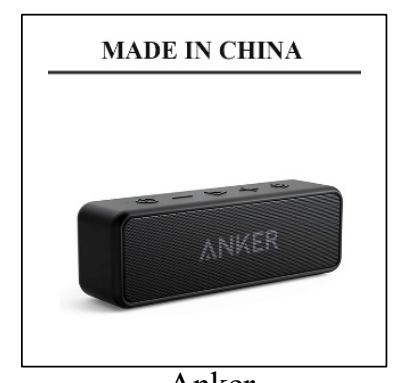

Anker

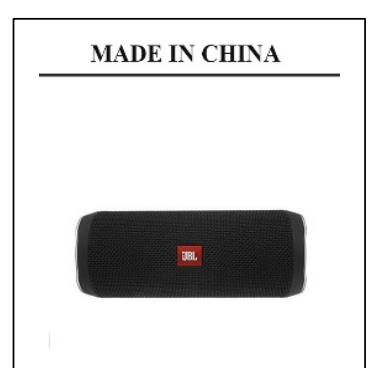

JBL

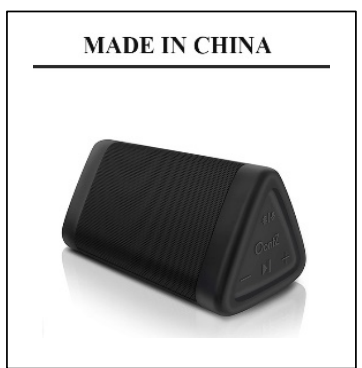

Oontz 
How likely are you to purchase the following brands the next time you consider purchasing a Bluetooth speaker?

\begin{tabular}{c|ccccc} 
& Extremely unlikely & Somewhat unlikely & $\begin{array}{c}\text { Neither likely nor } \\
\text { unlikely }\end{array}$ & Somewhat likely & Extremely likely \\
\hline $\begin{array}{c}\text { DigiShack } \\
\text { Bluetooth speaker }\end{array}$ & 0 & 0 & 0 & \\
$\begin{array}{c}\text { JBL Flip Bluetooth } \\
\text { speaker }\end{array}$ & 0 & 0 & 0 & & \\
$\begin{array}{c}\text { Oontz Bluetooth } \\
\text { speaker }\end{array}$ & 0 & 0 & 0 & 0 & 0 \\
$\begin{array}{c}\text { Anker Bluetooth } \\
\text { speaker }\end{array}$ & 0 & 0 & 0 & 0 & 0 \\
& & & & &
\end{tabular}

Please click on the hyperlink below and decide which product you would prefer to purchase, then select it from the list below.

https://storebrandz.myshopify.com/admin/themes/104982904995/editor\#/collections/sb-chargers-mexico

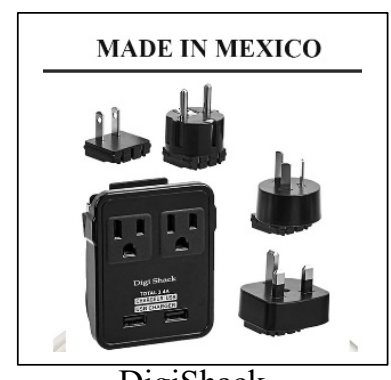

DigiShack

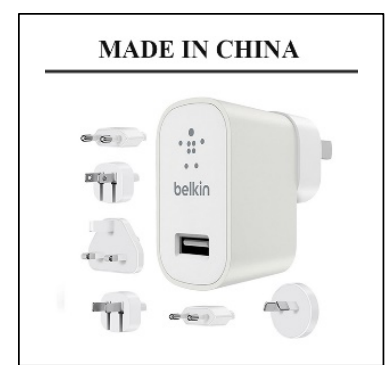

Belkin

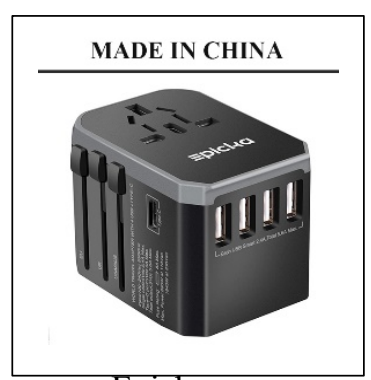

Epicka

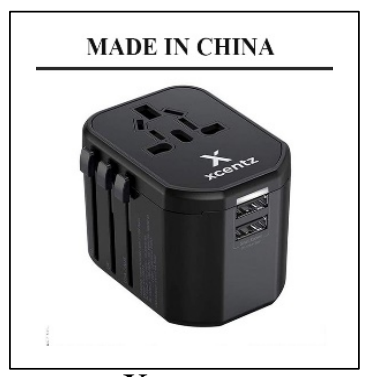

Xcentz

How likely are you to purchase the following brands the next time you consider purchasing a Universal travel adapter?

\begin{tabular}{c|ccccc} 
& Extremely unlikely & Somewhat unlikely & $\begin{array}{c}\text { Neither likely nor } \\
\text { unlikely }\end{array}$ & Somewhat likely & Extremely likely \\
\hline $\begin{array}{c}\text { DigiShack } \\
\text { universal charger }\end{array}$ & 0 & 0 & 0 & \\
$\begin{array}{c}\text { Belkin universal } \\
\text { charger }\end{array}$ & 0 & 0 & 0 & \\
$\begin{array}{c}\text { Xcentz universal } \\
\text { charger }\end{array}$ & 0 & 0 & 0 & 0 & 0 \\
$\begin{array}{c}\text { Epicka universal } \\
\text { charger }\end{array}$ & 0 & 0 & 0 & 0 & \\
\end{tabular}


Indicate the extent to which you agree with the following statements.

\begin{tabular}{c|ccccccc} 
& $\begin{array}{c}\text { Strongly } \\
\text { disagree }\end{array}$ & Disagree & $\begin{array}{c}\text { Somewhat } \\
\text { disagree }\end{array}$ & $\begin{array}{c}\text { Neither } \\
\text { agree nor } \\
\text { disagree }\end{array}$ & $\begin{array}{c}\text { Somewhat } \\
\text { agree }\end{array}$ & Agree & $\begin{array}{c}\text { Strongly } \\
\text { agree }\end{array}$ \\
\hline $\begin{array}{c}\text { DigiShack } \\
\text { is an e- } \\
\text { retailer } \\
\text { with good } \\
\text { reputation }\end{array}$ & 0 & 0 & 0 & 0 & 0 & 0 & \\
\end{tabular}

Using the scale given below, please indicate how you felt about online product information pages.

\begin{tabular}{|c|c|c|c|c|c|c|c|c|}
\hline & $\begin{array}{l}\text { Extremely } \\
\text { negative } \\
(-3)\end{array}$ & $\begin{array}{c}\text { Very } \\
\text { negative } \\
(-2)\end{array}$ & $\begin{array}{l}\text { Negative } \\
(-1)\end{array}$ & Neutral & $\begin{array}{l}\text { Positive } \\
(+1)\end{array}$ & $\begin{array}{c}\text { Very } \\
\text { Positive } \\
(+2)\end{array}$ & $\begin{array}{l}\text { Extremely } \\
\text { positive } \\
(+3)\end{array}$ & \\
\hline & 1 & 2 & 3 & 4 & 5 & 6 & 7 & \\
\hline Unhappy & 0 & $\bigcirc$ & $\bigcirc$ & $\bigcirc$ & 0 & $\bigcirc$ & ○ & Happy \\
\hline Annoyed & $\bigcirc$ & 0 & $\bigcirc$ & $\bigcirc$ & $\bigcirc$ & 0 & ○ & Pleased \\
\hline $\begin{array}{c}\text { Dis- } \\
\text { satisfied }\end{array}$ & 0 & 0 & 0 & 0 & 0 & 0 & 0 & Satisfied \\
\hline Melancholic & $\bigcirc$ & 0 & $\bigcirc$ & $\bigcirc$ & ○ & 0 & ○ & contended \\
\hline Despairing & 0 & 0 & 0 & 0 & 0 & 0 & ○ & Hopeful \\
\hline Bored & $\bigcirc$ & $\bigcirc$ & $\bigcirc$ & ○ & $\bigcirc$ & 0 & ○ & Relaxed \\
\hline Sluggish & ○ & 0 & 0 & ○ & 0 & 0 & ○ & Frenzied \\
\hline Dull & 0 & 0 & 0 & ○ & 0 & 0 & ○ & Jittery \\
\hline Unaroused & $\bigcirc$ & $\bigcirc$ & 0 & ○ & $\bigcirc$ & 0 & ○ & aroused \\
\hline Relaxed & ○ & $\bigcirc$ & $\bigcirc$ & ○ & 0 & 0 & ○ & Stimulated \\
\hline Calm & $\bigcirc$ & $\bigcirc$ & $\bigcirc$ & $\bigcirc$ & $\bigcirc$ & 0 & ○ & Excited \\
\hline Sleepy & 0 & ○ & $\bigcirc$ & $\bigcirc$ & ○ & ○ & ○ & $\begin{array}{c}\text { Wide } \\
\text { awake }\end{array}$ \\
\hline
\end{tabular}


In general, how do you feel about the following countries?

\begin{tabular}{c|ccccccc} 
& $\begin{array}{c}\text { Extremely } \\
\text { unfavorable }\end{array}$ & $\begin{array}{c}\text { Moderately } \\
\text { unfavorable }\end{array}$ & $\begin{array}{c}\text { Slightly } \\
\text { unfavorable }\end{array}$ & $\begin{array}{c}\text { Neither } \\
\text { favorable nor } \\
\text { unfavorable }\end{array}$ & $\begin{array}{c}\text { Slightly } \\
\text { favorable }\end{array}$ & $\begin{array}{c}\text { Moderately } \\
\text { favorable }\end{array}$ & $\begin{array}{c}\text { Extremely } \\
\text { favorable }\end{array}$ \\
\hline Mexico & 0 & 0 & 0 & 0 & 0 & 0 \\
South Korea & 0 & 0 & 0 & 0 & 0 & 0 \\
Russia & 0 & 0 & 0 & 0 & 0 & 0 & 0 \\
China & 0 & 0 & 0 & 0 & 0 & 0 & 0 \\
India & 0 & 0 & 0 & 0 & 0 & 0 & 0
\end{tabular}

What Gender do you identify with?

Male

Female

Other

Prefer not to say

What is your age?
Under 18
$18-25$
$26-35$
$36-45$
$46-55$
$56+$

What is your annual household income?

Less than $\$ 25,000$

$\$ 25,000-\$ 50,000$

$\$ 50,000-100,000$

$\$ 100,000-200,000$

More than 200,000

Prefer not to say (6) 


\section{Study 2: Questionnaire}

Are you currently using an iPhone?
Yes
No

Do you reside in the USA?
Yes
No

Please indicate your ethnicity:

Caucasian White

African American

American Indian

European (Western)

European (Eastern)

Hispanic/Latino

Asian

Others (Please specify)

Prefer not to say

Please read the following information carefully before answering the following questions.

Imagine you're going on a vacation and you have realised that you need to buy a few items online. For choosing a product, please click on the given hyperlinks which will prompt you to a product page from where you have to choose a product, then select it from the list given in the survey questions. 
Block 1:

Please click on the hyperlink below and decide which product you would prefer to purchase, then select it from the list below.

https://storebrandz.myshopify.com/collections/iphone-lightning-cable-abll

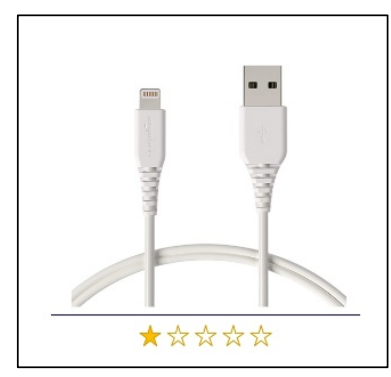

AmazonBasics

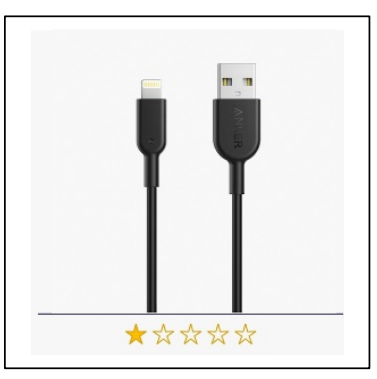

Anker

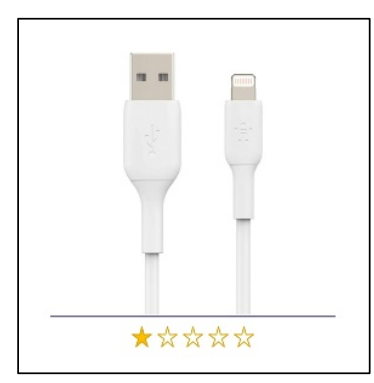

Belkin

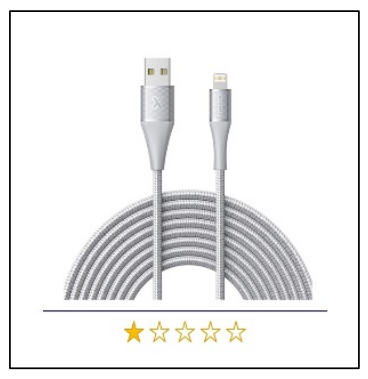

Xcentz

How likely are you to purchase the following brands the next time you consider purchasing an iPhone cable?

\begin{tabular}{|c|c|c|c|c|c|}
\hline & $\begin{array}{l}\text { Extremely } \\
\text { unlikely }\end{array}$ & $\begin{array}{l}\text { Somewhat } \\
\text { unlikely }\end{array}$ & $\begin{array}{c}\text { Neither likely } \\
\text { nor unlikely }\end{array}$ & $\begin{array}{c}\text { Somewhat } \\
\text { likely }\end{array}$ & $\begin{array}{c}\text { Extremely } \\
\text { likely }\end{array}$ \\
\hline AmazonBasics & $\checkmark$ & 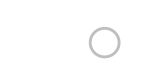 & $\checkmark$ & $\checkmark$ & $\checkmark$ \\
\hline Belkin & $\checkmark$ & 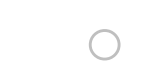 & & O & O \\
\hline Anker & ○ & ○ & O & $\bigcirc$ & $\bigcirc$ \\
\hline Xcentz & $\bigcirc$ & O & 0 & 0 & 0 \\
\hline
\end{tabular}

Please click on the hyperlink below and decide which product you would prefer to purchase, then select it from the list below.

https://storebrandz.myshopify.com/collections/bluetooth-speakers-abll

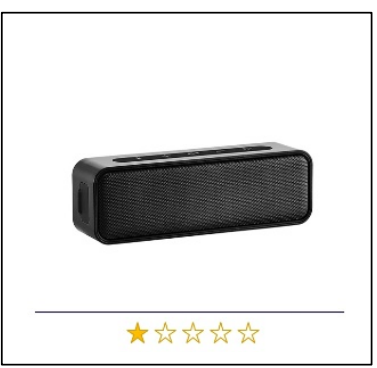

AmazonBasics

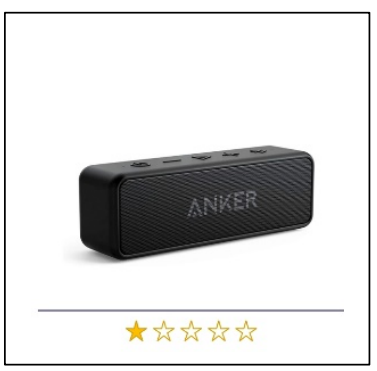

Anker

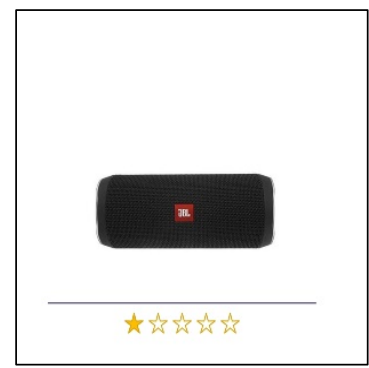

JBL

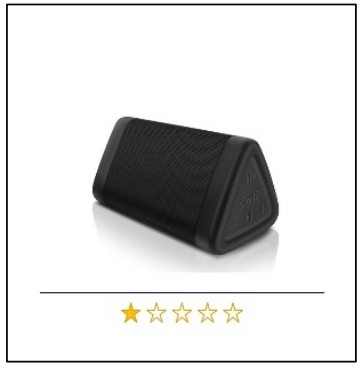

Oontz 
How likely are you to purchase the following brands the next time you consider purchasing a Bluetooth speaker?

\begin{tabular}{|c|c|c|c|c|c|}
\hline & $\begin{array}{l}\text { Extremely } \\
\text { unlikely }\end{array}$ & $\begin{array}{l}\text { Somewhat } \\
\text { unlikely }\end{array}$ & $\begin{array}{l}\text { Neither likely } \\
\text { nor unlikely }\end{array}$ & $\begin{array}{l}\text { Somewhat } \\
\text { likely }\end{array}$ & $\begin{array}{l}\text { Extremely } \\
\text { likely }\end{array}$ \\
\hline AmazonBasics & 0 & $U$ & 0 & 0 & 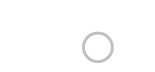 \\
\hline JBL & 0 & ○ & O & O & 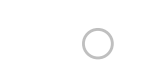 \\
\hline Oontz & O & 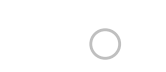 & $U$ & O & U \\
\hline Anker & O & 0 & O & O & ○ \\
\hline
\end{tabular}

Please click on the hyperlink below and decide which product you would prefer to purchase, then select it from the list below.

https://storebrandz.myshopify.com/collections/universal-adapters-abll

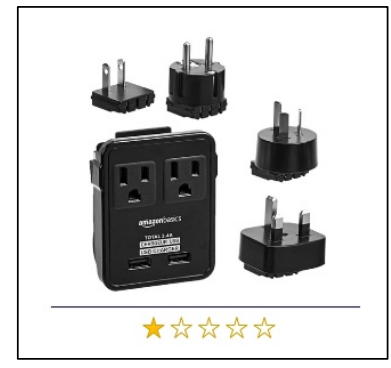

AmazonBasics

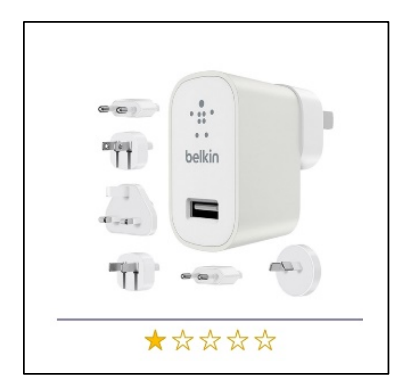

Belkin

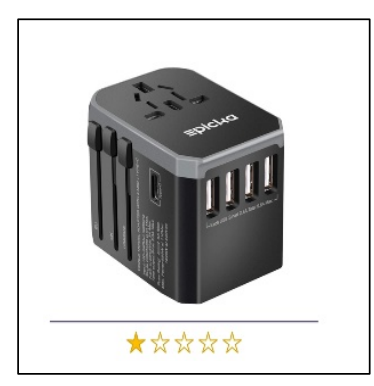

Epicka

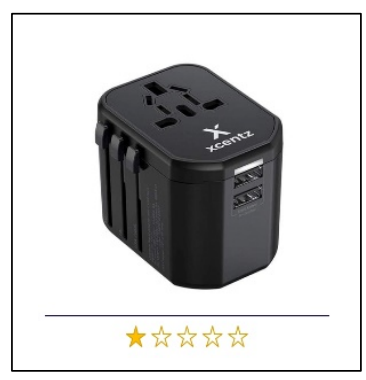

Xcentz

How likely are you to purchase the following brands the next time you consider purchasing a Universal travel adapter?

\begin{tabular}{|c|c|c|c|c|c|}
\hline & $\begin{array}{l}\text { Extremely } \\
\text { unlikely }\end{array}$ & $\begin{array}{l}\text { Somewhat } \\
\text { unlikely }\end{array}$ & $\begin{array}{l}\text { Neither likely } \\
\text { nor unlikely }\end{array}$ & $\begin{array}{l}\text { Somewhat } \\
\text { likely }\end{array}$ & $\begin{array}{l}\text { Extremely } \\
\text { likely }\end{array}$ \\
\hline AmazonBasics & $\bigcirc$ & $\bigcirc$ & $\bigcirc$ & $\bigcirc$ & $\bigcirc$ \\
\hline Belkin & $\bigcirc$ & $\bigcirc$ & $\bigcirc$ & $\bigcirc$ & $\bigcirc$ \\
\hline Xcentz & $\bigcirc$ & $\bigcirc$ & $\bigcirc$ & $\bigcirc$ & $\bigcirc$ \\
\hline Epicka & $\bigcirc$ & $\bigcirc$ & $\bigcirc$ & $\bigcirc$ & $\bigcirc$ \\
\hline
\end{tabular}


Indicate the extent to which you agree with the following statement.

\begin{tabular}{c|ccccccc} 
& $\begin{array}{c}\text { Strongly } \\
\text { disagree }\end{array}$ & Disagree & $\begin{array}{c}\text { Somewhat } \\
\text { disagree }\end{array}$ & $\begin{array}{c}\text { Neither agree } \\
\text { nor disagree }\end{array}$ & $\begin{array}{c}\text { Somewhat } \\
\text { agree }\end{array}$ & $\begin{array}{c}\text { Agree } \\
\text { agree }\end{array}$ \\
\hline $\begin{array}{c}\text { Amazon is an } \\
\text { e-retailer } \\
\text { with good } \\
\text { reputation }\end{array}$ & 0 & 0 & 0 & 0 & & \\
\end{tabular}

In your opinion, what is the level of quality for the following products?

\begin{tabular}{|c|c|c|c|c|c|}
\hline & Extremely low & Somewhat low & $\begin{array}{c}\text { Neither high nor } \\
\text { low }\end{array}$ & Somewhat high & Extremely high \\
\hline AmazonBasics & $\bigcirc$ & ○ & $\bigcirc$ & ○ & $\bigcirc$ \\
\hline Anker & $\bigcirc$ & $\bigcirc$ & $\bigcirc$ & $\bigcirc$ & $\bigcirc$ \\
\hline Belkin & $\bigcirc$ & $\bigcirc$ & $\bigcirc$ & $\bigcirc$ & $\bigcirc$ \\
\hline Epicka & $\bigcirc$ & $\bigcirc$ & $\bigcirc$ & $\bigcirc$ & ○ \\
\hline $\mathrm{JBL}$ & $\bigcirc$ & $\bigcirc$ & $\bigcirc$ & $\bigcirc$ & $\bigcirc$ \\
\hline Oontz & $\bigcirc$ & $\bigcirc$ & $\bigcirc$ & $\bigcirc$ & $\bigcirc$ \\
\hline Xcentz & $\bigcirc$ & $\bigcirc$ & $\bigcirc$ & $\bigcirc$ & $\bigcirc$ \\
\hline
\end{tabular}

Block 2:

Please click on the hyperlink below and decide which product you would prefer to purchase, then select it from the list below.

https://storebrandz.myshopify.com/collections/iphone-lightning-cables-ablh
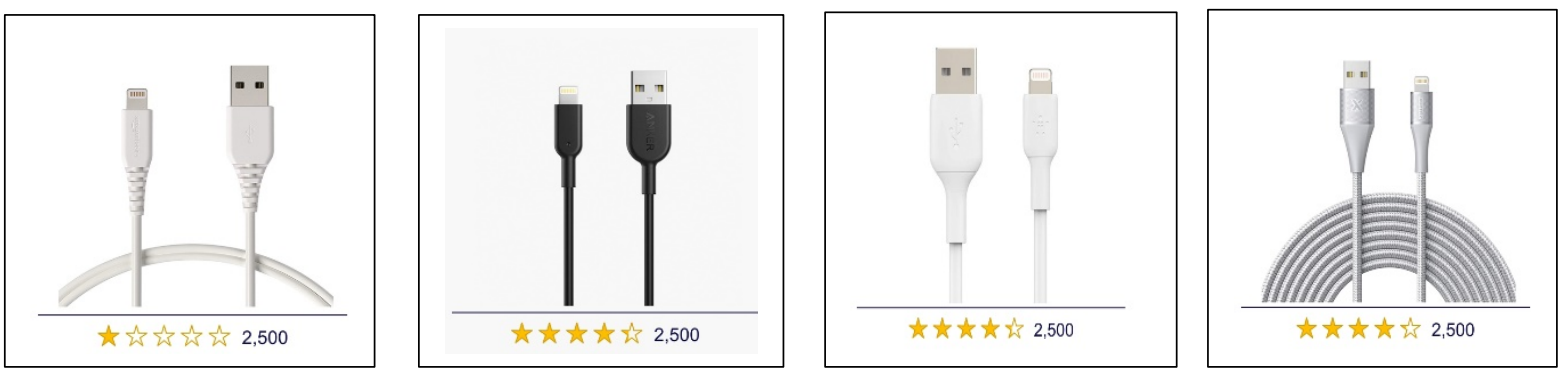
How likely are you to purchase the following brands the next time you consider purchasing an iPhone cable?

\begin{tabular}{|c|c|c|c|c|c|}
\hline & $\begin{array}{l}\text { Extremely } \\
\text { unlikely }\end{array}$ & $\begin{array}{l}\text { Somewhat } \\
\text { unlikely }\end{array}$ & $\begin{array}{l}\text { Neither likely } \\
\text { nor unlikely }\end{array}$ & $\begin{array}{l}\text { Somewhat } \\
\text { likely }\end{array}$ & $\begin{array}{c}\text { Extremely } \\
\text { likely }\end{array}$ \\
\hline Amazon Basics & $\bigcirc$ & $\bigcirc$ & $\bigcirc$ & $\bigcirc$ & $\bigcirc$ \\
\hline Belkin & $\bigcirc$ & $\bigcirc$ & $\bigcirc$ & $\bigcirc$ & $\bigcirc$ \\
\hline Anker & $\bigcirc$ & $\bigcirc$ & $\bigcirc$ & $\bigcirc$ & $\bigcirc$ \\
\hline Xcentz & $\bigcirc$ & O & $\bigcirc$ & $\bigcirc$ & $\bigcirc$ \\
\hline
\end{tabular}

Please click on the hyperlink below and decide which product you would prefer to purchase, then select it from the list below.

https://storebrandz.myshopify.com/collections/bluetooth-speakers-ablh

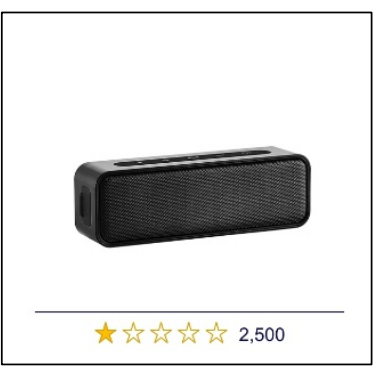

AmazonBasics

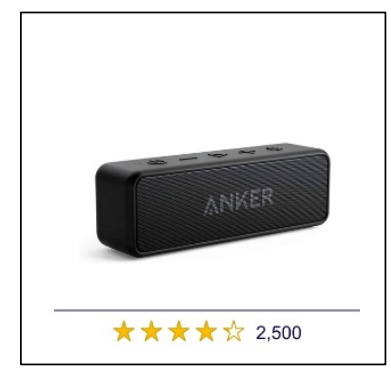

Anker

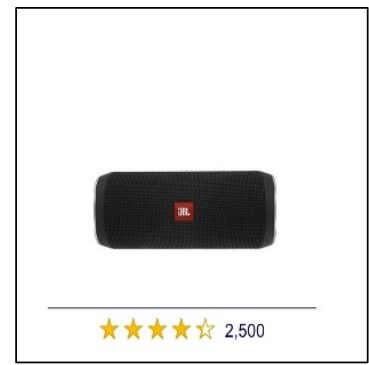

Belkin

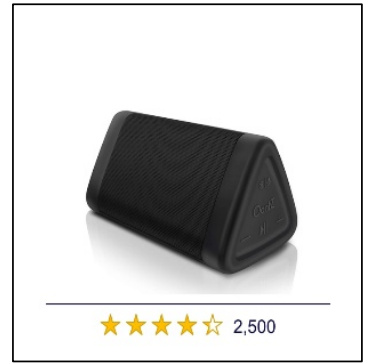

Xcentz

How likely are you to purchase the following brands the next time you consider purchasing a Bluetooth speaker?

\begin{tabular}{c|ccccc} 
& $\begin{array}{c}\text { Extremely } \\
\text { unlikely }\end{array}$ & $\begin{array}{c}\text { Somewhat } \\
\text { unlikely }\end{array}$ & $\begin{array}{c}\text { Neither likely } \\
\text { nor unlikely }\end{array}$ & $\begin{array}{c}\text { Somewhat } \\
\text { likely }\end{array}$ & $\begin{array}{c}\text { Extremely } \\
\text { likely }\end{array}$ \\
\hline AmazonBasics & & & & & \\
JBL & 0 & 0 & 0 & 0 & \\
Oontz & 0 & 0 & 0 & 0 & \\
Anker & & & & &
\end{tabular}

Please click on the hyperlink below and decide which product you would prefer to purchase, then select it from the list below. 
https://storebrandz.myshopify.com/collections/universal-adapters-ablh

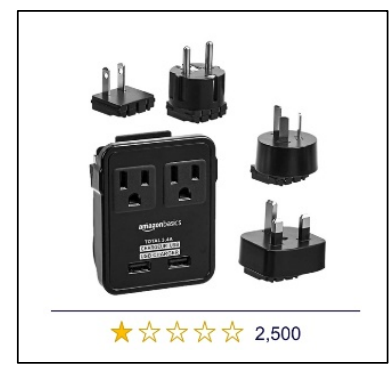

AmazonBasics

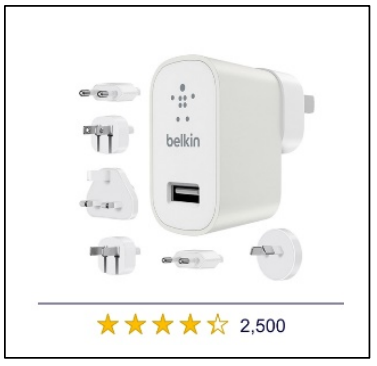

Anker

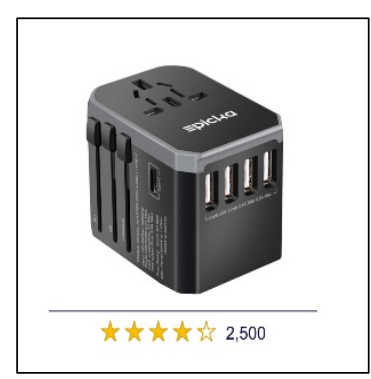

Belkin

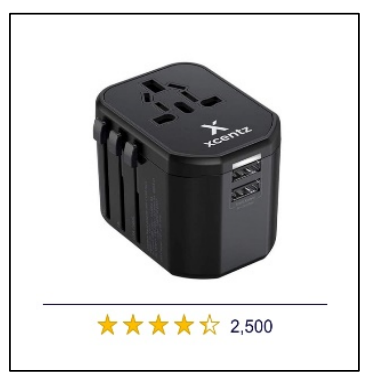

Xcentz

How likely are you to purchase the following brands the next time you consider purchasing a Universal travel adapter?

\begin{tabular}{|c|c|c|c|c|c|}
\hline & $\begin{array}{l}\text { Extremely } \\
\text { unlikely }\end{array}$ & $\begin{array}{l}\text { Somewhat } \\
\text { unlikely }\end{array}$ & $\begin{array}{l}\text { Neither likely } \\
\text { nor unlikely }\end{array}$ & $\begin{array}{l}\text { Somewhat } \\
\text { likely }\end{array}$ & $\begin{array}{l}\text { Extremely } \\
\text { likely }\end{array}$ \\
\hline AmazonBasics & $\bigcirc$ & $\bigcirc$ & $\bigcirc$ & $\bigcirc$ & $\bigcirc$ \\
\hline Belkin & $\bigcirc$ & $\bigcirc$ & $\bigcirc$ & $\bigcirc$ & ○ \\
\hline Xcentz & $\bigcirc$ & $\bigcirc$ & $\bigcirc$ & ○ & ○ \\
\hline Epicka & $\bigcirc$ & $\bigcirc$ & $\bigcirc$ & $\bigcirc$ & $\bigcirc$ \\
\hline
\end{tabular}


Indicate the extent to which you agree with the following statement.

\begin{tabular}{|c|c|c|c|c|c|c|c|}
\hline & $\begin{array}{l}\text { Strongly } \\
\text { disagree }\end{array}$ & Disagree & $\begin{array}{c}\text { Somewhat } \\
\text { disagree }\end{array}$ & $\begin{array}{c}\text { Neither } \\
\text { agree nor } \\
\text { disagree }\end{array}$ & $\begin{array}{c}\text { Somewhat } \\
\text { agree }\end{array}$ & Agree & $\begin{array}{c}\text { Strongly } \\
\text { agree }\end{array}$ \\
\hline $\begin{array}{l}\text { Amazon is } \\
\text { an e- } \\
\text { retailer } \\
\text { with good } \\
\text { reputation }\end{array}$ & $\bigcirc$ & $\bigcirc$ & $\bigcirc$ & $\bigcirc$ & $\bigcirc$ & O & $\bigcirc$ \\
\hline
\end{tabular}

In your opinion, what is the level of quality for the following products?

\begin{tabular}{|c|c|c|c|c|c|}
\hline & Extremely low & Somewhat low & $\begin{array}{l}\text { Neither high } \\
\text { nor low }\end{array}$ & Somewhat high & Extremely high \\
\hline AmazonBasics & ○ & $\checkmark$ & $\checkmark$ & $\checkmark$ & $\bigcirc$ \\
\hline Anker & O & 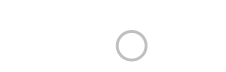 & 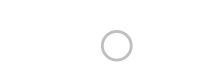 & 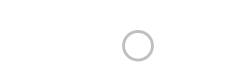 & 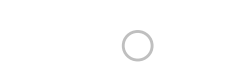 \\
\hline Belkin & ○ & $\checkmark$ & 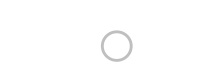 & 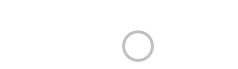 & 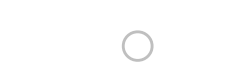 \\
\hline Epicka & O & ○ & $\checkmark$ & O & 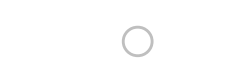 \\
\hline JBL & O & O & $\mathcal{U}$ & 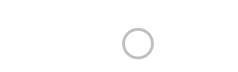 & $\checkmark$ \\
\hline Oontz & $\bigcirc$ & O & 0 & 0 & 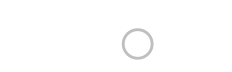 \\
\hline Xcentz & O & 0 & ) & & \\
\hline
\end{tabular}

Block 3:

Please click on the hyperlink below and decide which product you would prefer to purchase, then select it from the list below.

https://storebrandz.myshopify.com/collections/iphone-lightning-cable-abhl

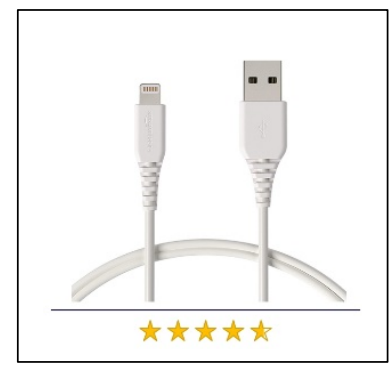

AmazonBasics

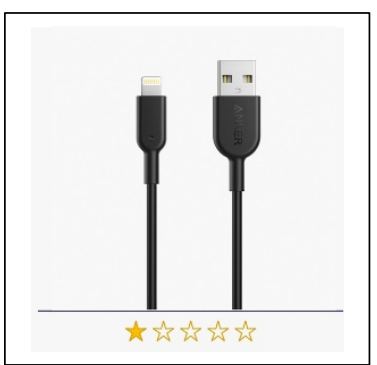

Anker

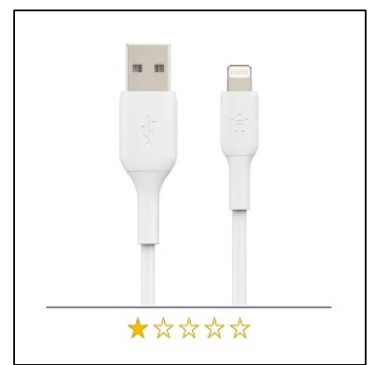

Belkin

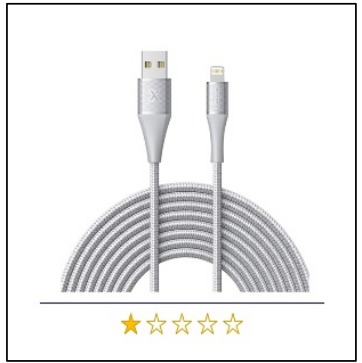

Xcentz 
How likely are you to purchase the following brands the next time you consider purchasing an iPhone cable?

\begin{tabular}{|c|c|c|c|c|c|}
\hline & $\begin{array}{c}\text { Extremely } \\
\text { unlikely }\end{array}$ & $\begin{array}{c}\text { Somewhat } \\
\text { unlikely }\end{array}$ & $\begin{array}{c}\text { Neither likely } \\
\text { nor unlikely }\end{array}$ & $\begin{array}{l}\text { Somewhat } \\
\text { likely }\end{array}$ & $\begin{array}{c}\text { Extremely } \\
\text { likely }\end{array}$ \\
\hline AmazonBasics & 0 & 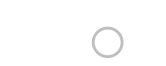 & 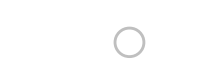 & 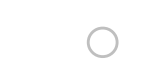 & 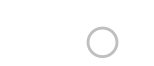 \\
\hline Belkin & $\bigcirc$ & $\checkmark$ & $\checkmark$ & 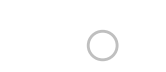 & 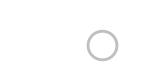 \\
\hline Anker & $\bigcirc$ & O & O & 0 & 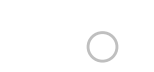 \\
\hline Xcentz & O & D & 0 & 0 & D \\
\hline
\end{tabular}

Please click on the hyperlink below and decide which product you would prefer to purchase, then select it from the list below.

https://storebrandz.myshopify.com/collections/bluetooth-speakers-abhl

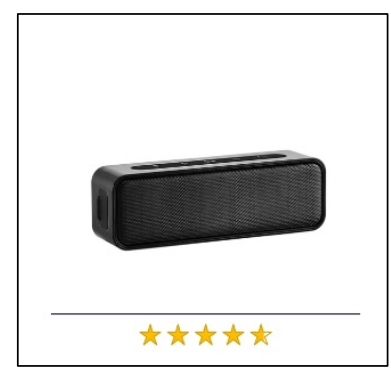

AmazonBasics

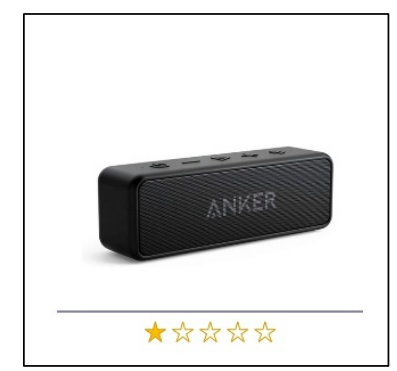

Anker

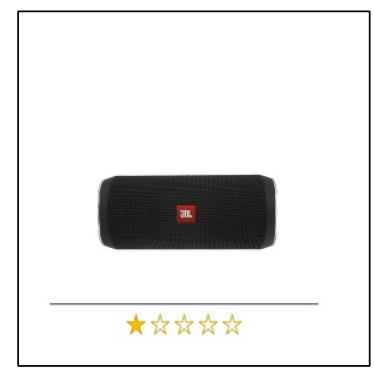

JBL

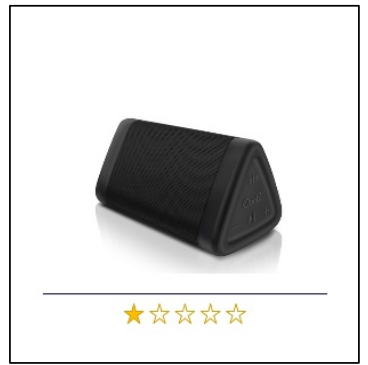

Oontz

How likely are you to purchase the following brands the next time you consider purchasing a Bluetooth speaker?

\begin{tabular}{|c|c|c|c|c|c|}
\hline & $\begin{array}{l}\text { Extremely } \\
\text { unlikely }\end{array}$ & $\begin{array}{c}\text { Somewhat } \\
\text { unlikely }\end{array}$ & $\begin{array}{c}\text { Neither likely } \\
\text { nor unlikely }\end{array}$ & $\begin{array}{c}\text { Somewhat } \\
\text { likely }\end{array}$ & $\begin{array}{c}\text { Extremely } \\
\text { likely }\end{array}$ \\
\hline AmazonBasics & $\bigcirc$ & & 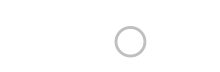 & $\bigcirc$ & O \\
\hline $\mathrm{JBL}$ & 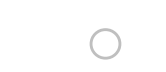 & & & $\bigcirc$ & $\bigcirc$ \\
\hline Oontz & O & O & 0 & O & $\bigcirc$ \\
\hline Anker & ○ & O & $\bigcirc$ & $\mathrm{O}$ & $\bigcirc$ \\
\hline
\end{tabular}


Please click on the hyperlink below and decide which product you would prefer to purchase, then select it from the list below.

https://storebrandz.myshopify.com/collections/universal-adapter-abhl

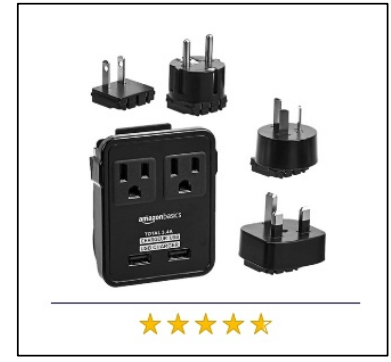

AmazonBasics

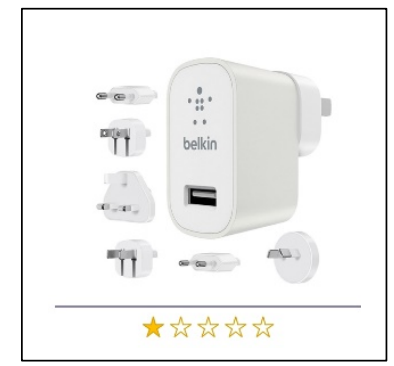

Belkin

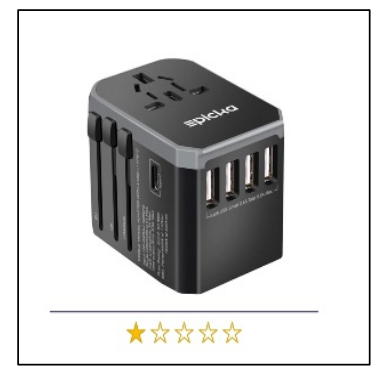

Epicka

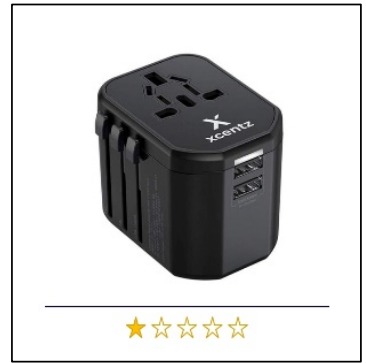

Xcentz

How likely are you to purchase the following brands the next time you consider purchasing a Universal travel adapter?

$\begin{array}{ccccc}\begin{array}{c}\text { Extremely } \\ \text { unlikely }\end{array} & \begin{array}{c}\text { Somewhat } \\ \text { unlikely }\end{array} & \begin{array}{c}\text { Neither likely } \\ \text { nor unlikely }\end{array} & \begin{array}{c}\text { Somewhat } \\ \text { likely }\end{array} & \begin{array}{c}\text { Extremely } \\ \text { likely }\end{array}\end{array}$

AmazonBasics

Belkin

Xcentz

Epicka 
Indicate the extent to which you agree with the following statement.

\begin{tabular}{|c|c|c|c|c|c|c|c|}
\hline & $\begin{array}{l}\text { Strongly } \\
\text { disagree }\end{array}$ & Disagree & $\begin{array}{c}\text { Somewhat } \\
\text { disagree }\end{array}$ & $\begin{array}{l}\text { Neither } \\
\text { agree nor } \\
\text { disagree }\end{array}$ & $\begin{array}{c}\text { Somewhat } \\
\text { agree }\end{array}$ & Agree & $\begin{array}{c}\text { Strongly } \\
\text { agree }\end{array}$ \\
\hline $\begin{array}{l}\text { Amazon is } \\
\text { an e- } \\
\text { retailer } \\
\text { with good } \\
\text { reputation }\end{array}$ & $\bigcirc$ & $\bigcirc$ & $\bigcirc$ & $\bigcirc$ & $\bigcirc$ & $\bigcirc$ & $\bigcirc$ \\
\hline
\end{tabular}

In your opinion, what is the level of quality for the following products?

\begin{tabular}{|c|c|c|c|c|c|}
\hline & Extremely low & Somewhat low & $\begin{array}{l}\text { Neither high } \\
\text { nor low }\end{array}$ & Somewhat high & Extremely high \\
\hline AmazonBasics & O & ○ & $\bigcirc$ & 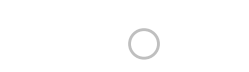 & 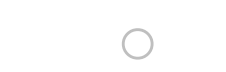 \\
\hline Anker & $\bigcirc$ & $\bigcirc$ & 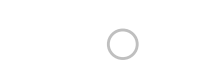 & $\bigcirc$ & O \\
\hline Belkin & ○ & 0 & $\mathcal{J}$ & 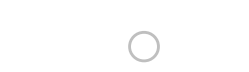 & $\checkmark$ \\
\hline Epicka & O & 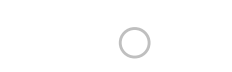 & & $\bigcirc$ & O \\
\hline JBL & $\bigcirc$ & $\bigcirc$ & & & C \\
\hline Oontz & $\bigcirc$ & $\bigcirc$ & O & ○ & O \\
\hline Xcentz & 0 & $\bigcirc$ & ) & O & $U$ \\
\hline
\end{tabular}

Block 4:

Please click on the hyperlink below and decide which product you would prefer to purchase, then select it from the list below.

https://storebrandz.myshopify.com/collections/iphone-lightning-cable-abhh

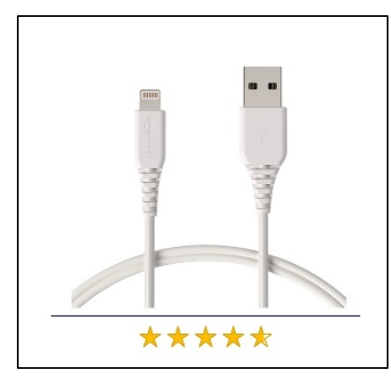

AmazonBasics

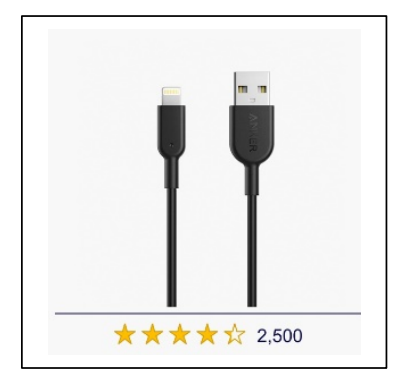

Anker

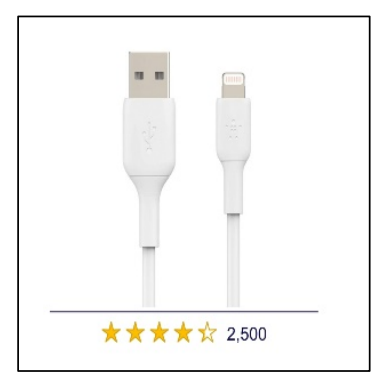

Belkin

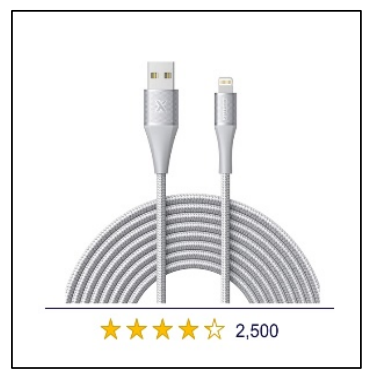

Xcentz 
How likely are you to purchase the following brands the next time you consider purchasing an iPhone cable?

\begin{tabular}{|c|c|c|c|c|c|}
\hline & $\begin{array}{l}\text { Extremely } \\
\text { unlikely }\end{array}$ & $\begin{array}{l}\text { Somewhat } \\
\text { unlikely }\end{array}$ & $\begin{array}{c}\text { Neither likely } \\
\text { nor unlikely }\end{array}$ & $\begin{array}{c}\text { Somewhat } \\
\text { likely }\end{array}$ & $\begin{array}{l}\text { Extremely } \\
\text { likely }\end{array}$ \\
\hline Amazon Basics & 0 & 0 & 0 & 0 & 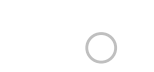 \\
\hline Belkin & 0 & 0 & $U$ & 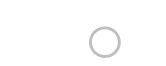 & 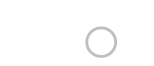 \\
\hline Anker & ○ & O & O & O & $\checkmark$ \\
\hline Xcentz & $\bigcirc$ & $\bigcirc$ & $\bigcirc$ & $\bigcirc$ & 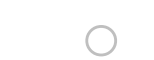 \\
\hline
\end{tabular}

Please click on the hyperlink below and decide which product you would prefer to purchase, then select it from the list below.

https://storebrandz.myshopify.com/collections/bluetooth-speakers-abhh

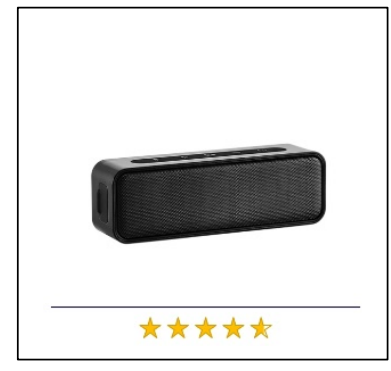

AmazonBasics

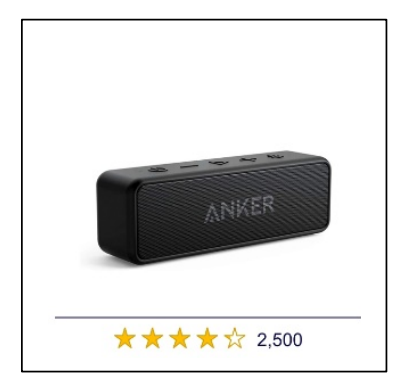

Anker

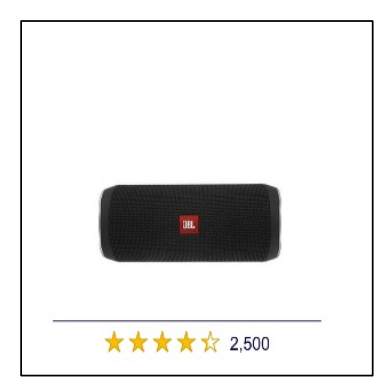

Belkin

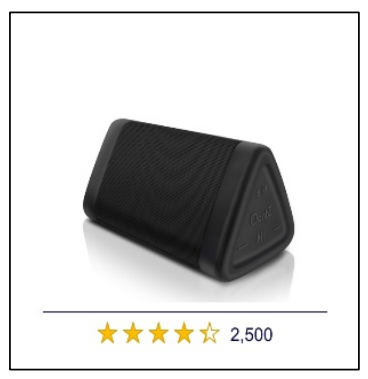

Xcentz

How likely are you to purchase the following brands the next time you consider purchasing a Bluetooth speaker?

\begin{tabular}{c|ccccc} 
& $\begin{array}{c}\text { Extremely } \\
\text { unlikely }\end{array}$ & $\begin{array}{c}\text { Somewhat } \\
\text { unlikely }\end{array}$ & $\begin{array}{c}\text { Neither likely } \\
\text { nor unlikely }\end{array}$ & $\begin{array}{c}\text { Somewhat } \\
\text { likely }\end{array}$ & $\begin{array}{c}\text { Extremely } \\
\text { likely }\end{array}$ \\
\hline AmazonBasics & & & & & \\
JBL & 0 & 0 & 0 & 0 & \\
Oontz & 0 & 0 & 0 & 0 & \\
Anker & & & & &
\end{tabular}


Please click on the hyperlink below and decide which product you would prefer to purchase, then select it from $\mathrm{t}$ he list below.

https://storebrandz.myshopify.com/collections/universal-adapter-abhh

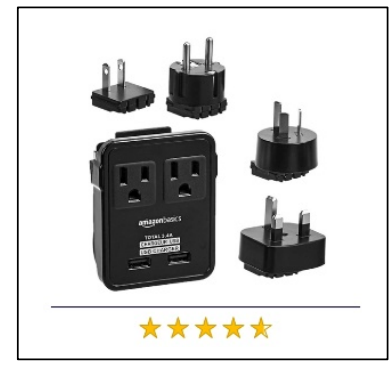

AmazonBasics

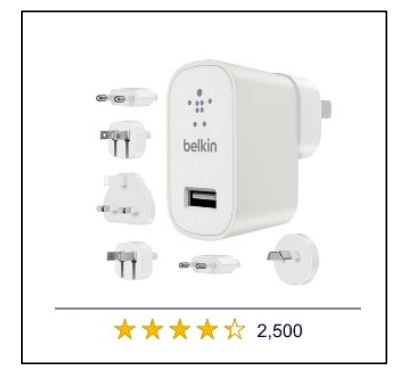

Anker

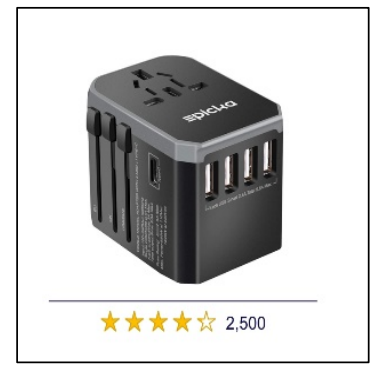

Belkin

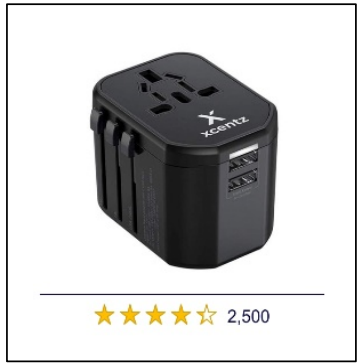

Xcentz

How likely are you to purchase the following brands the next time you consider purchasing a Universal travel adapter?

\begin{tabular}{c|ccccc} 
& $\begin{array}{c}\text { Extremely } \\
\text { unlikely }\end{array}$ & $\begin{array}{c}\text { Somewhat } \\
\text { unlikely }\end{array}$ & $\begin{array}{c}\text { Neither likely } \\
\text { nor unlikely }\end{array}$ & $\begin{array}{c}\text { Somewhat } \\
\text { likely }\end{array}$ & $\begin{array}{c}\text { Extremely } \\
\text { likely }\end{array}$ \\
\hline AmazonBasics & & & & & \\
Belkin & 0 & 0 & 0 & 0 & \\
Xcentz & 0 & 0 & 0 & 0 & \\
Epicka & 0 & 0 & 0 & 0 &
\end{tabular}

Indicate the extent to which you agree with the following statement.

\begin{tabular}{c|ccccccc} 
& $\begin{array}{c}\text { Strongly } \\
\text { disagree }\end{array}$ & Disagree & $\begin{array}{c}\text { Somewhat } \\
\text { disagree }\end{array}$ & $\begin{array}{c}\text { Neither } \\
\text { agree nor } \\
\text { disagree }\end{array}$ & $\begin{array}{c}\text { Somewhat } \\
\text { agree }\end{array}$ & Agree & $\begin{array}{c}\text { Strongly } \\
\text { agree }\end{array}$ \\
\hline $\begin{array}{c}\text { Amazon is } \\
\text { an e- } \\
\text { retailer } \\
\text { with good } \\
\text { reputation }\end{array}$ & 0 & 0 & 0 & 0 & 0 & & \\
\end{tabular}


In your opinion, what is the level of quality for the following products?

\begin{tabular}{|c|c|c|c|c|c|}
\hline & Extremely low & Somewhat low & $\begin{array}{l}\text { Neither high nor } \\
\text { low }\end{array}$ & Somewhat high & Extremely high \\
\hline AmazonBasics & $\checkmark$ & & 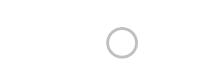 & 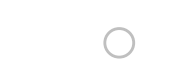 & $\checkmark$ \\
\hline Anker & $\bigcirc$ & & ○ & 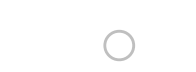 & 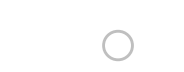 \\
\hline Belkin & 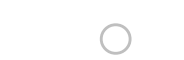 & ( & 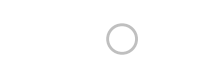 & 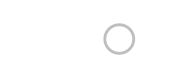 & 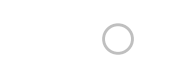 \\
\hline Epicka & O & O & 0 & 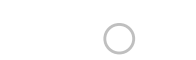 & U \\
\hline JBL & $\bigcirc$ & 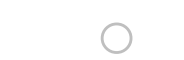 & 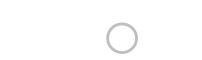 & 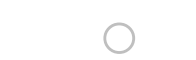 & 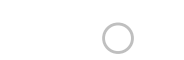 \\
\hline Oontz & ○ & O & O & O & 0 \\
\hline Xcentz & $\bigcirc$ & D & ר & O & $\checkmark$ \\
\hline
\end{tabular}

\section{Block 5:}

Please click on the hyperlink below and decide which product you would prefer to purchase, then select it from the list below.

https://storebrandz.myshopify.com/collections/iphone-lightning-cable-dsll

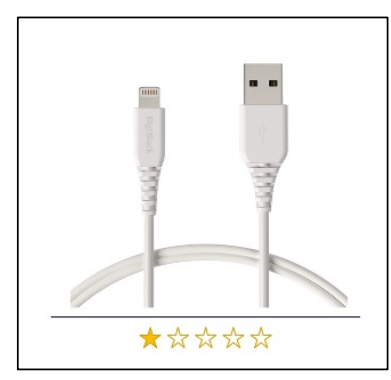

DigiShack

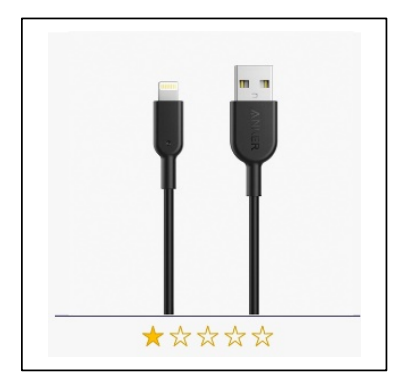

Belkin

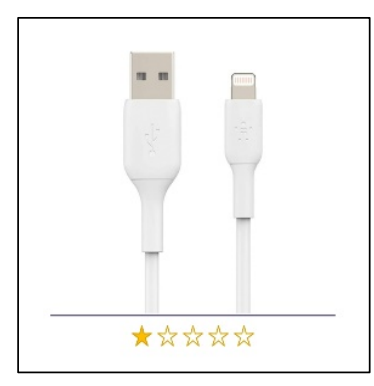

Epicka

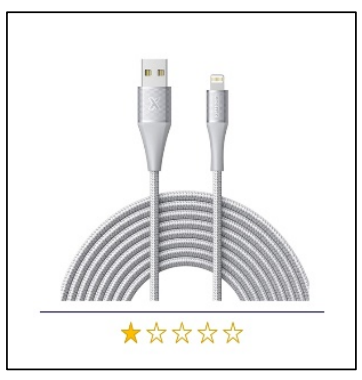

Xcentz 
How likely are you to purchase the following brands the next time you consider purchasing an iPhone cable?

\begin{tabular}{l|ccccc} 
& $\begin{array}{c}\text { Extremely } \\
\text { unlikely }\end{array}$ & $\begin{array}{c}\text { Somewhat } \\
\text { unlikely }\end{array}$ & $\begin{array}{c}\text { Neither likely } \\
\text { nor unlikely }\end{array}$ & $\begin{array}{c}\text { Somewhat } \\
\text { likely }\end{array}$ & $\begin{array}{c}\text { Extremely } \\
\text { likely }\end{array}$ \\
\hline DigiShack & & & & \\
Belkin & 0 & 0 & 0 & \\
Anker & & & & \\
Xcentz & & & & \\
\end{tabular}

Please click on the hyperlink below and decide which product you would prefer to purchase, then select it from the list below.

https://storebrandz.myshopify.com/collections/bluetooth-speakers-dsll

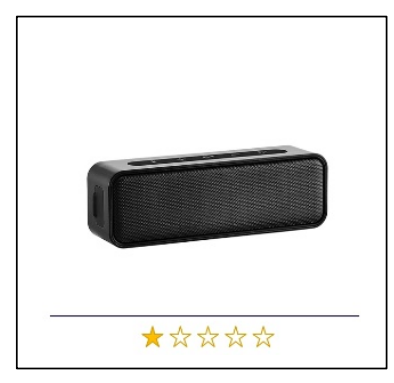

DigiShack

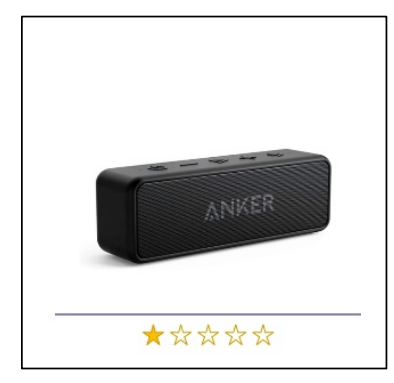

Anker

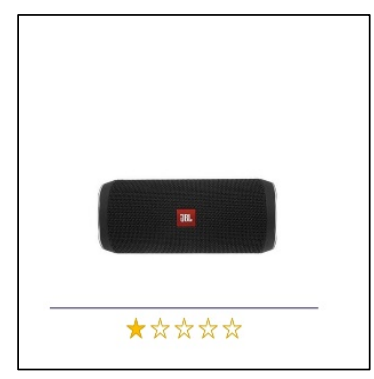

JBL

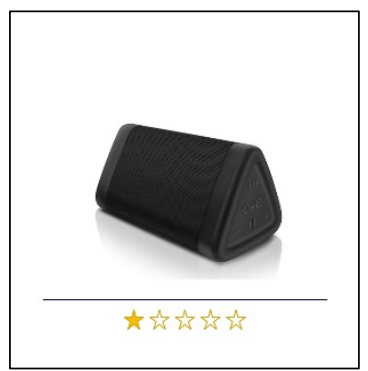

Oontz

How likely are you to purchase the following brands the next time you consider purchasing a Bluetooth speaker?

\begin{tabular}{|c|c|c|c|c|c|}
\hline & $\begin{array}{c}\text { Extremely } \\
\text { unlikely }\end{array}$ & $\begin{array}{l}\text { Somewhat } \\
\text { unlikely }\end{array}$ & $\begin{array}{l}\text { Neither likely } \\
\text { nor unlikely }\end{array}$ & $\begin{array}{l}\text { Somewhat } \\
\text { likely }\end{array}$ & $\begin{array}{l}\text { Extremely } \\
\text { likely }\end{array}$ \\
\hline DigiShack & 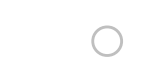 & 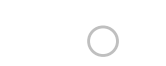 & 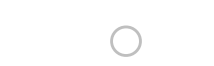 & 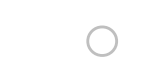 & , \\
\hline JBL & 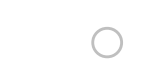 & 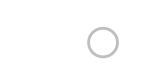 & 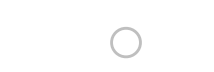 & 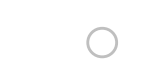 & \\
\hline Oontz & ○ & O & O & O & 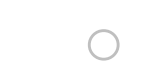 \\
\hline Anker & O & ○ & 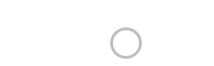 & 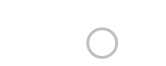 & $\mathcal{U}$ \\
\hline
\end{tabular}


Please click on the hyperlink below and decide which product you would prefer to purchase, then select it from $t$ he list below.

https://storebrandz.myshopify.com/collections/universal-adapter-dsll

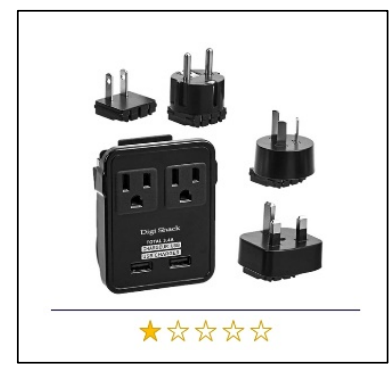

DigiShack

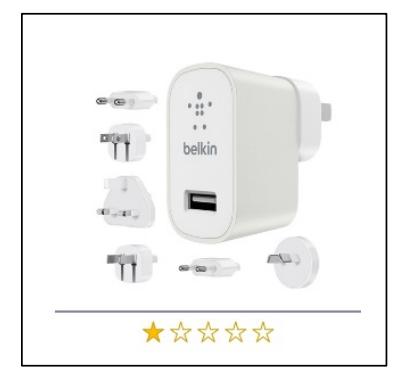

Belkin

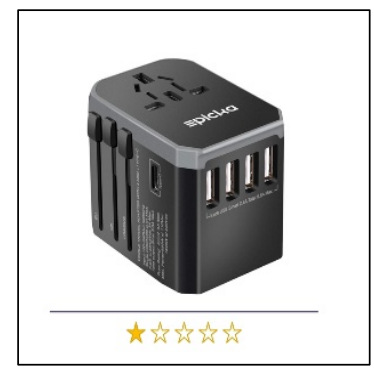

Epicka

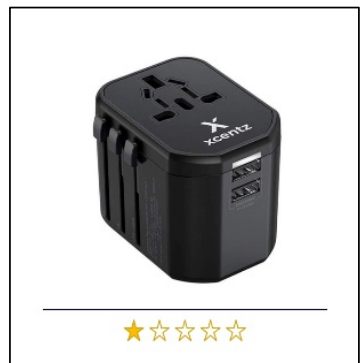

Xcentz

How likely are you to purchase the following brands the next time you consider purchasing a Universal travel adapter?

\begin{tabular}{|c|c|c|c|c|c|}
\hline & $\begin{array}{l}\text { Extremely } \\
\text { unlikely }\end{array}$ & $\begin{array}{c}\text { Somewhat } \\
\text { unlikely }\end{array}$ & $\begin{array}{l}\text { Neither likely } \\
\text { nor unlikely }\end{array}$ & $\begin{array}{l}\text { Somewhat } \\
\text { likely }\end{array}$ & $\begin{array}{l}\text { Extremely } \\
\text { likely }\end{array}$ \\
\hline DigiShack & $\bigcirc$ & $\bigcirc$ & $\bigcirc$ & $\bigcirc$ & $\bigcirc$ \\
\hline Belkin & $\bigcirc$ & $\bigcirc$ & $\bigcirc$ & $\bigcirc$ & $\bigcirc$ \\
\hline Xcentz & ○ & $\bigcirc$ & 0 & $\bigcirc$ & 0 \\
\hline Epicka & $\bigcirc$ & $\bigcirc$ & $\bigcirc$ & $\bigcirc$ & ○ \\
\hline
\end{tabular}

Indicate the extent to which you agree with the following statements.

\begin{tabular}{c|ccccccc} 
& $\begin{array}{c}\text { Strongly } \\
\text { disagree }\end{array}$ & Disagree & $\begin{array}{c}\text { Somewhat } \\
\text { disagree }\end{array}$ & $\begin{array}{c}\text { Neither } \\
\text { agree nor } \\
\text { disagree }\end{array}$ & $\begin{array}{c}\text { Somewhat } \\
\text { agree }\end{array}$ & Agree & $\begin{array}{c}\text { Strongly } \\
\text { agree }\end{array}$ \\
\hline $\begin{array}{c}\text { DigiShack } \\
\text { is an e- } \\
\text { retailer } \\
\text { with good } \\
\text { reputation }\end{array}$ & 0 & 0 & 0 & 0 & 0 & & \\
& & & & &
\end{tabular}


In your opinion, what is the level of quality for the following products?

\begin{tabular}{|c|c|c|c|c|c|}
\hline & Extremely low & Somewhat low & $\begin{array}{c}\text { Neither high nor } \\
\text { low }\end{array}$ & Somewhat high & Extremely high \\
\hline DigiShack & $\checkmark$ & $\checkmark$ & $\checkmark$ & $\checkmark$ & 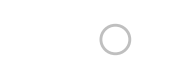 \\
\hline Anker & ○ & 0 & 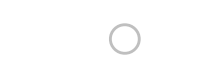 & 0 & 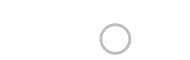 \\
\hline Belkin & U & 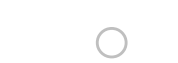 & 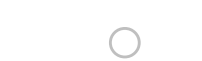 & $U$ & 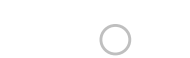 \\
\hline Epicka & 0 & ○ & 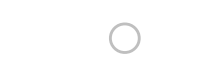 & O & $\mathcal{U}$ \\
\hline JBL & 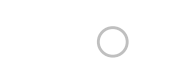 & 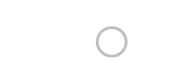 & 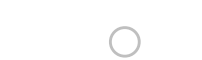 & 0 & $\checkmark$ \\
\hline Oontz & ○ & ○ & 0 & 0 & O \\
\hline Xcentz & $J$ & $\checkmark$ & 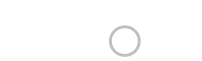 & 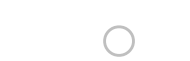 & $\checkmark$ \\
\hline
\end{tabular}

Block 6:

Please click on the hyperlink below and decide which product you would prefer to purchase, then select it from the list below.

https://storebrandz.myshopify.com/collections/iphone-lightning-cable-dslh

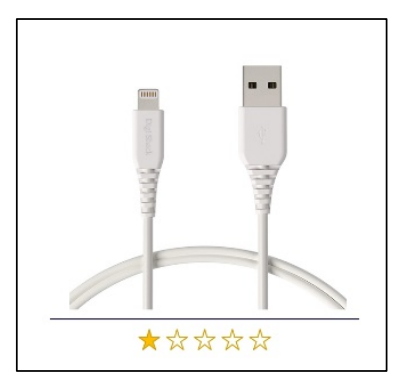

DigiShack

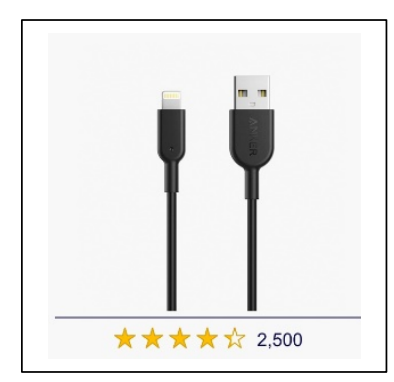

Anker

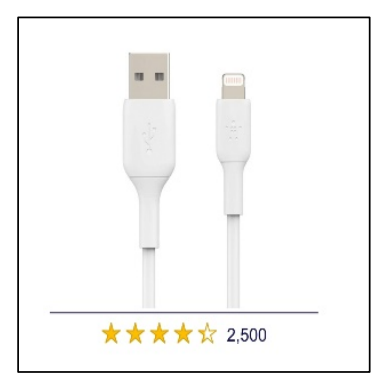

Belkin

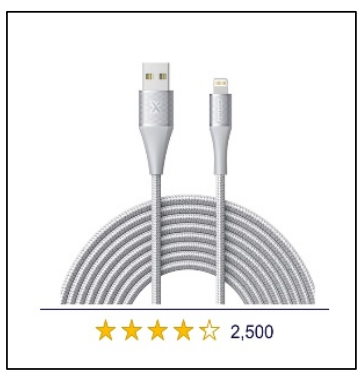

Xcentz 
How likely are you to purchase the following brands the next time you consider purchasing an iPhone cable?

\begin{tabular}{|c|c|c|c|c|c|}
\hline & Extremely unlikely & Somewhat unlikely & $\begin{array}{l}\text { Neither likely nor } \\
\text { unlikely }\end{array}$ & Somewhat likely & Extremely likely \\
\hline DigiShack & $\bigcirc$ & $\bigcirc$ & $\bigcirc$ & $\bigcirc$ & $\bigcirc$ \\
\hline Belkin & $\bigcirc$ & $\bigcirc$ & $\bigcirc$ & $\bigcirc$ & ○ \\
\hline Anker & $\bigcirc$ & $\bigcirc$ & $\bigcirc$ & $\bigcirc$ & O \\
\hline Xcentz & $\bigcirc$ & ○ & ○ & ○ & $\bigcirc$ \\
\hline
\end{tabular}

Please click on the hyperlink below and decide which product you would prefer to purchase, then select it from the list below.

https://storebrandz.myshopify.com/collections/bluetooth-speakers-dslh

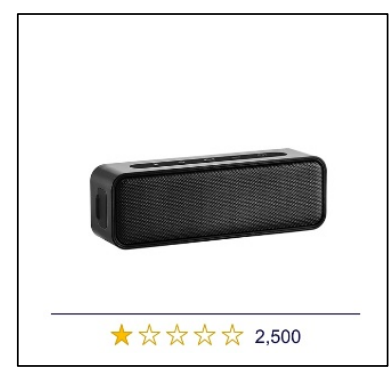

DigiShack

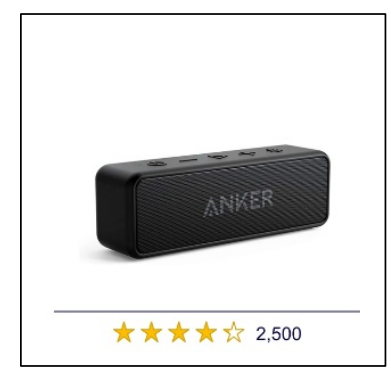

Anker

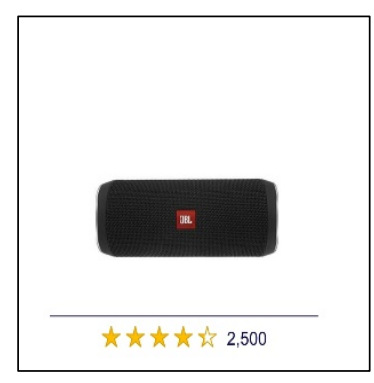

Belkin

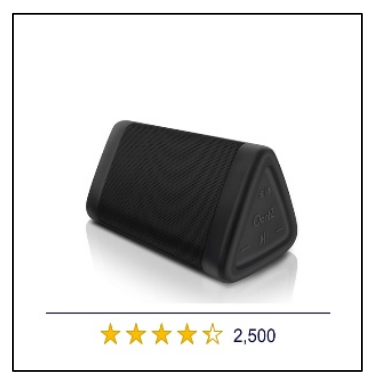

Xcentz

How likely are you to purchase the following brands the next time you consider purchasing a Bluetooth speaker?

\begin{tabular}{|c|c|c|c|c|c|}
\hline & $\begin{array}{c}\text { Extremely } \\
\text { unlikely }\end{array}$ & $\begin{array}{l}\text { Somewhat } \\
\text { unlikely }\end{array}$ & $\begin{array}{c}\text { Neither likely } \\
\text { nor unlikely }\end{array}$ & $\begin{array}{l}\text { Somewhat } \\
\text { likely }\end{array}$ & $\begin{array}{c}\text { Extremely } \\
\text { likely }\end{array}$ \\
\hline DigiShack & 0 & $\bigcirc$ & $\bigcirc$ & 0 & 0 \\
\hline JBL & 0 & 0 & 0 & 0 & 0 \\
\hline Oontz & 0 & $\bigcirc$ & $\bigcirc$ & 0 & 0 \\
\hline Anker & 0 & $\bigcirc$ & $\bigcirc$ & 0 & 0 \\
\hline
\end{tabular}


Please click on the hyperlink below and decide which product you would prefer to purchase, then select it from the list below.

\section{https://storebrandz.myshopify.com/collections/universal-adapter-dslh}

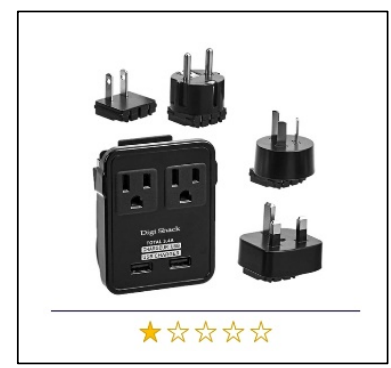

DigiShack

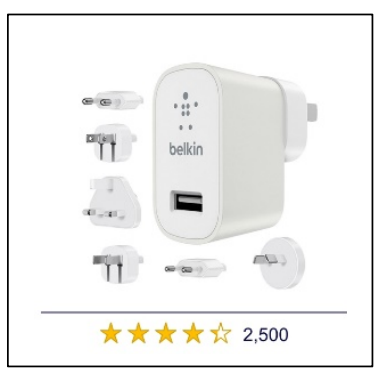

Anker

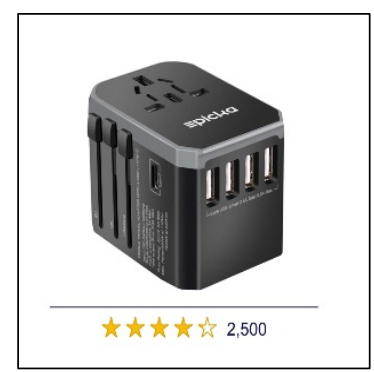

Belkin

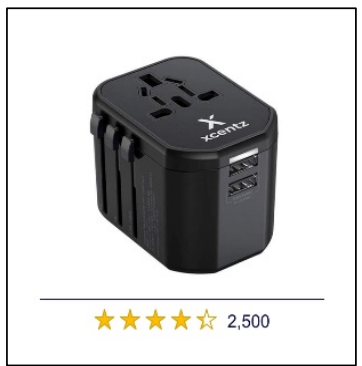

Xcentz

How likely are you to purchase the following brands the next time you consider purchasing a Universal travel adapter?

\begin{tabular}{|c|c|c|c|c|c|}
\hline & $\begin{array}{l}\text { Extremely } \\
\text { unlikely }\end{array}$ & $\begin{array}{l}\text { Somewhat } \\
\text { unlikely }\end{array}$ & $\begin{array}{l}\text { Neither likely } \\
\text { nor unlikely }\end{array}$ & $\begin{array}{l}\text { Somewhat } \\
\text { likely }\end{array}$ & $\begin{array}{c}\text { Extremely } \\
\text { likely }\end{array}$ \\
\hline DigiShack & $\bigcirc$ & $\bigcirc$ & $\bigcirc$ & $\bigcirc$ & $\bigcirc$ \\
\hline Belkin & $\bigcirc$ & $\bigcirc$ & $\bigcirc$ & $\bigcirc$ & $\bigcirc$ \\
\hline Xcentz & ○ & $\bigcirc$ & $\bigcirc$ & $\bigcirc$ & $\bigcirc$ \\
\hline Epicka & ○ & $\bigcirc$ & $\bigcirc$ & $\bigcirc$ & 0 \\
\hline
\end{tabular}

Indicate the extent to which you agree with the following statements.

\begin{tabular}{c|ccccccc} 
& $\begin{array}{c}\text { Strongly } \\
\text { disagree }\end{array}$ & Disagree & $\begin{array}{c}\text { Somewhat } \\
\text { disagree }\end{array}$ & $\begin{array}{c}\text { Neither } \\
\text { agree nor } \\
\text { disagree }\end{array}$ & $\begin{array}{c}\text { Somewhat } \\
\text { agree }\end{array}$ & Agree & $\begin{array}{c}\text { Strongly } \\
\text { agree }\end{array}$ \\
\hline $\begin{array}{c}\text { DigiShack } \\
\text { is an e- } \\
\text { retailer } \\
\text { with good } \\
\text { reputation }\end{array}$ & 0 & 0 & 0 & 0 & 0 & 0 & \\
& & & & &
\end{tabular}


In your opinion, what is the level of quality for the following products?

\begin{tabular}{|c|c|c|c|c|c|}
\hline & Extremely low & Somewhat low & $\begin{array}{l}\text { Neither high nor } \\
\text { low }\end{array}$ & Somewhat high & Extremely high \\
\hline DigiShack & $\bigcirc$ & $\bigcirc$ & $\bigcirc$ & $\bigcirc$ & $\bigcirc$ \\
\hline Anker & $\bigcirc$ & ○ & ○ & ○ & O \\
\hline Belkin & $\bigcirc$ & $\bigcirc$ & O & O & O \\
\hline Epicka & $\bigcirc$ & $\bigcirc$ & ○ & O & O \\
\hline JBL & $\bigcirc$ & $\bigcirc$ & $\bigcirc$ & O & O \\
\hline Oontz & $\bigcirc$ & O & $\bigcirc$ & O & ○ \\
\hline Xcentz & $\bigcirc$ & $\bigcirc$ & $\bigcirc$ & $\bigcirc$ & $\bigcirc$ \\
\hline
\end{tabular}

Block 7:

Please click on the hyperlink below and decide which product you would prefer to purchase, then select it from the list below.

https://storebrandz.myshopify.com/collections/iphone-lightning-cable-dshl

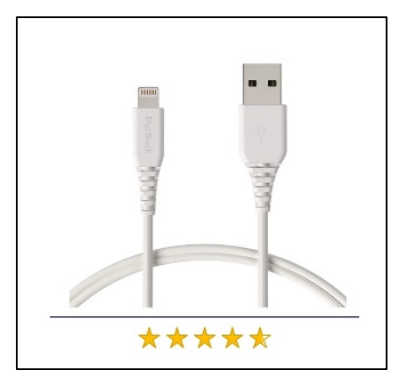

DigiShack

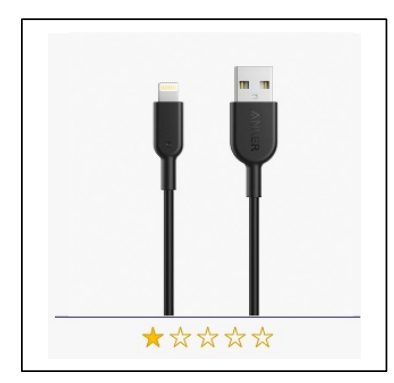

Anker

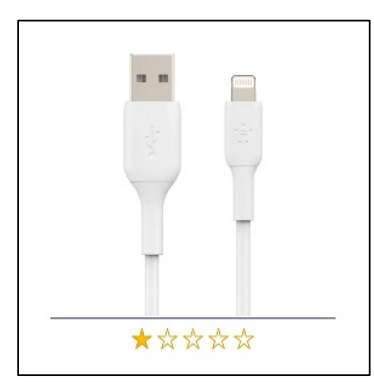

Belkin

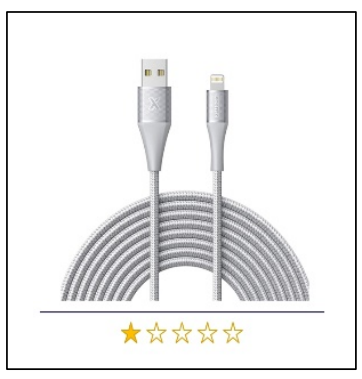

Xcentz 
How likely are you to purchase the following brands the next time you consider purchasing an iPhone cable?

\begin{tabular}{|c|c|c|c|c|c|}
\hline & $\begin{array}{l}\text { Extremely } \\
\text { unlikely }\end{array}$ & $\begin{array}{c}\text { Somewhat } \\
\text { unlikely }\end{array}$ & $\begin{array}{c}\text { Neither likely } \\
\text { nor unlikely }\end{array}$ & $\begin{array}{c}\text { Somewhat } \\
\text { likely }\end{array}$ & $\begin{array}{c}\text { Extremely } \\
\text { likely }\end{array}$ \\
\hline DigiShack & $\bigcirc$ & $\bigcirc$ & $\bigcirc$ & $\bigcirc$ & $\bigcirc$ \\
\hline Belkin & $\bigcirc$ & $\bigcirc$ & $\bigcirc$ & $\bigcirc$ & $\bigcirc$ \\
\hline Anker & O & ○ & ○ & O & ○ \\
\hline Xcentz & $\bigcirc$ & 0 & $\bigcirc$ & 0 & $\bigcirc$ \\
\hline
\end{tabular}

Please click on the hyperlink below and decide which product you would prefer to purchase, then select it from the list below.

https://storebrandz.myshopify.com/collections/bluetooth-speakers-dslh-1

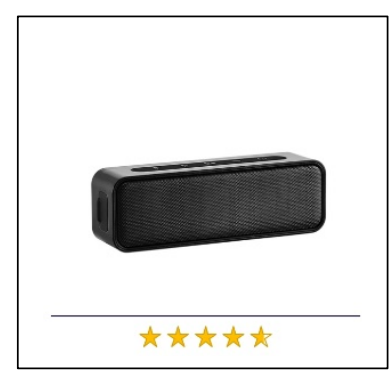

DigiShack

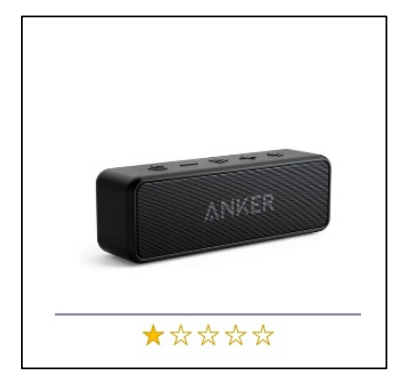

Anker

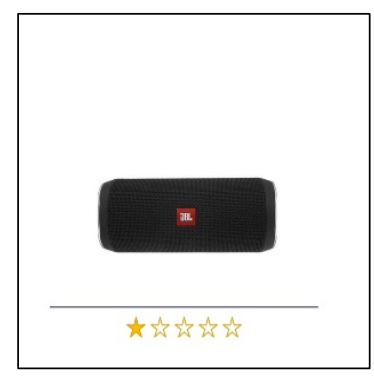

JBL

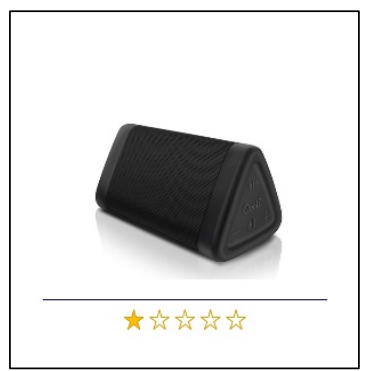

Oontz

How likely are you to purchase the following brands the next time you consider purchasing a Bluetooth speaker?

\begin{tabular}{|c|c|c|c|c|c|}
\hline & $\begin{array}{l}\text { Extremely } \\
\text { unlikely }\end{array}$ & $\begin{array}{l}\text { Somewhat } \\
\text { unlikely }\end{array}$ & $\begin{array}{c}\text { Neither likely } \\
\text { nor unlikely }\end{array}$ & $\begin{array}{l}\text { Somewhat } \\
\text { likely }\end{array}$ & $\begin{array}{c}\text { Extremely } \\
\text { likely }\end{array}$ \\
\hline DigiShack & 0 & $\bigcirc$ & $\bigcirc$ & 0 & 0 \\
\hline JBL & $\bigcirc$ & 0 & ○ & ○ & $\bigcirc$ \\
\hline Oontz & 0 & $\bigcirc$ & $\bigcirc$ & $\bigcirc$ & 0 \\
\hline Anker & 0 & 0 & $\bigcirc$ & $\bigcirc$ & 0 \\
\hline
\end{tabular}


Please click on the hyperlink below and decide which product you would prefer to purchase, then select it from the list below.

https://storebrandz.myshopify.com/collections/universal-adapter-dshl

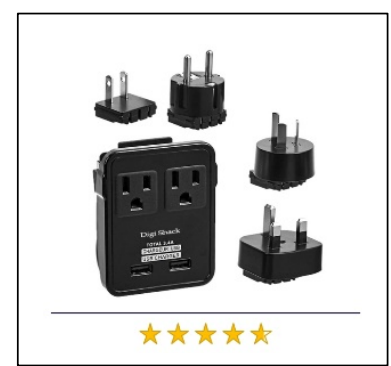

DigiShack

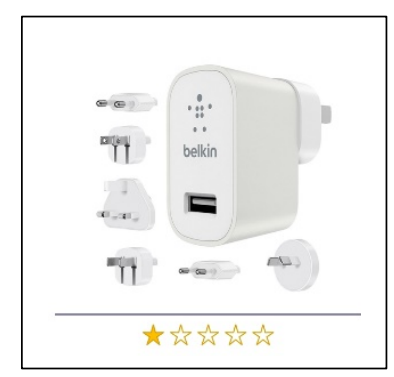

Belkin

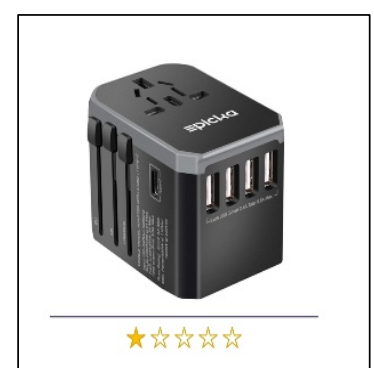

Epicka

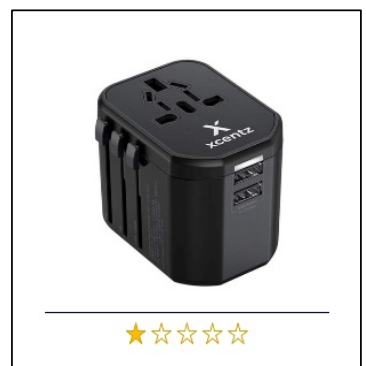

Xcentz

How likely are you to purchase the following brands the next time you consider purchasing a Universal travel adapter?

\begin{tabular}{c|ccccc} 
& $\begin{array}{c}\text { Extremely } \\
\text { unlikely }\end{array}$ & $\begin{array}{c}\text { Somewhat } \\
\text { unlikely }\end{array}$ & $\begin{array}{c}\text { Neither likely } \\
\text { nor unlikely }\end{array}$ & $\begin{array}{c}\text { Somewhat } \\
\text { likely }\end{array}$ & $\begin{array}{c}\text { Extremely } \\
\text { likely }\end{array}$ \\
\hline DigiShack & 0 & 0 & 0 & & \\
Belkin & 0 & 0 & 0 & \\
Xcentz & 0 & 0 & 0 & 0 & \\
Epicka & 0 & 0 & 0 & &
\end{tabular}

Indicate the extent to which you agree with the following statements.

\begin{tabular}{|c|c|c|c|c|c|c|c|}
\hline & $\begin{array}{l}\text { Strongly } \\
\text { disagree }\end{array}$ & Disagree & $\begin{array}{l}\text { Somewhat } \\
\text { disagree }\end{array}$ & $\begin{array}{l}\text { Neither } \\
\text { agree nor } \\
\text { disagree }\end{array}$ & $\begin{array}{l}\text { Somewhat } \\
\text { agree }\end{array}$ & Agree & $\begin{array}{c}\text { Strongly } \\
\text { agree }\end{array}$ \\
\hline $\begin{array}{l}\text { DigiShack } \\
\text { is an e- } \\
\text { retailer } \\
\text { with good } \\
\text { reputation }\end{array}$ & $\bigcirc$ & $\bigcirc$ & $\bigcirc$ & $\bigcirc$ & $\bigcirc$ & $\bigcirc$ & $\bigcirc$ \\
\hline
\end{tabular}


In your opinion, what is the level of quality for the following products?

\begin{tabular}{|c|c|c|c|c|c|}
\hline & Extremely low & Somewhat low & $\begin{array}{l}\text { Neither high nor } \\
\text { low }\end{array}$ & Somewhat high & Extremely high \\
\hline DigiShack & $\bigcirc$ & $\bigcirc$ & $\bigcirc$ & $\bigcirc$ & $\bigcirc$ \\
\hline Anker & O & O & $\bigcirc$ & $\bigcirc$ & $\bigcirc$ \\
\hline Belkin & O & ○ & $\bigcirc$ & O & $\bigcirc$ \\
\hline Epicka & O & O & O & O & $\bigcirc$ \\
\hline JBL & O & O & $\bigcirc$ & O & $\bigcirc$ \\
\hline Oontz & O & O & $\bigcirc$ & $\bigcirc$ & $\bigcirc$ \\
\hline Xcentz & $\bigcirc$ & $\bigcirc$ & $\bigcirc$ & $\bigcirc$ & $\bigcirc$ \\
\hline
\end{tabular}

Block 8:

Please click on the hyperlink below and decide which product you would prefer to purchase, then select it from the list below.

https://storebrandz.myshopify.com/collections/iphone-lightning-cable-dshh

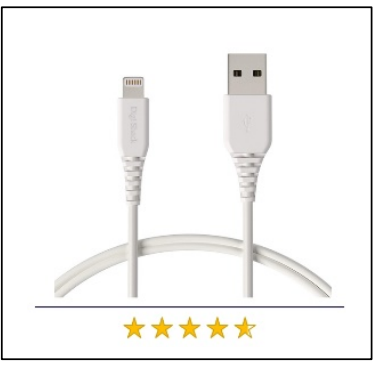

DigiShack

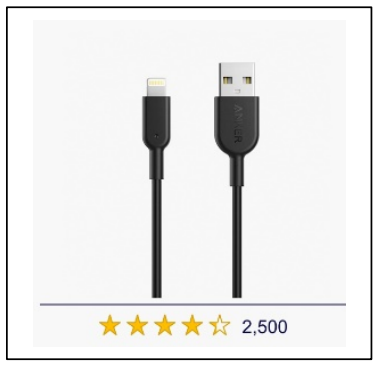

Anker

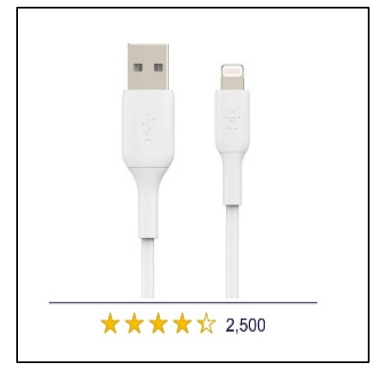

Belkin

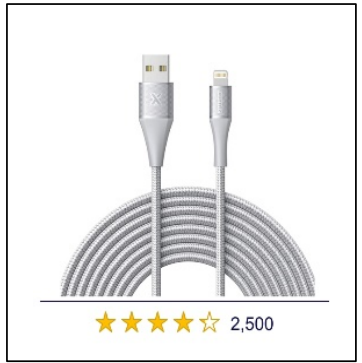

Xcentz 
How likely are you to purchase the following brands the next time you consider purchasing an iPhone cable?

\begin{tabular}{|c|c|c|c|c|c|}
\hline & $\begin{array}{l}\text { Extremely } \\
\text { unlikely }\end{array}$ & $\begin{array}{c}\text { Somewhat } \\
\text { unlikely }\end{array}$ & $\begin{array}{c}\text { Neither likely } \\
\text { nor unlikely }\end{array}$ & $\begin{array}{c}\text { Somewhat } \\
\text { likely }\end{array}$ & $\begin{array}{c}\text { Extremely } \\
\text { likely }\end{array}$ \\
\hline DigiShack & $\bigcirc$ & $\bigcirc$ & $\bigcirc$ & $\bigcirc$ & $\bigcirc$ \\
\hline Belkin & $\bigcirc$ & $\bigcirc$ & $\bigcirc$ & $\bigcirc$ & $\bigcirc$ \\
\hline Anker & O & ○ & ○ & O & ○ \\
\hline Xcentz & $\bigcirc$ & 0 & $\bigcirc$ & 0 & $\bigcirc$ \\
\hline
\end{tabular}

Please click on the hyperlink below and decide which product you would prefer to purchase, then select it from the list below.

https://storebrandz.myshopify.com/collections/bluetooth-speakers-dshh

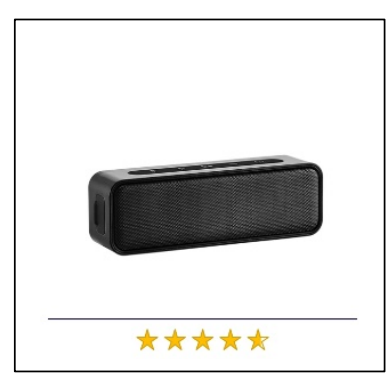

DigiShack

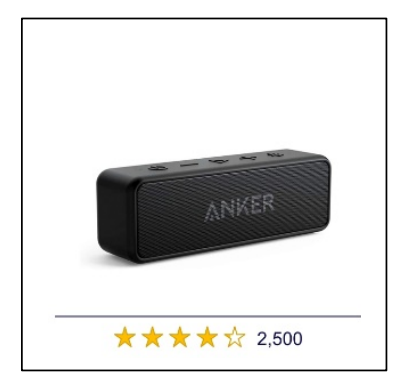

Anker

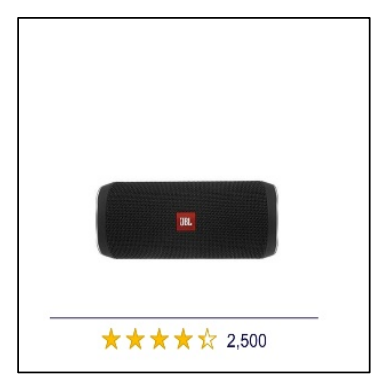

Belkin

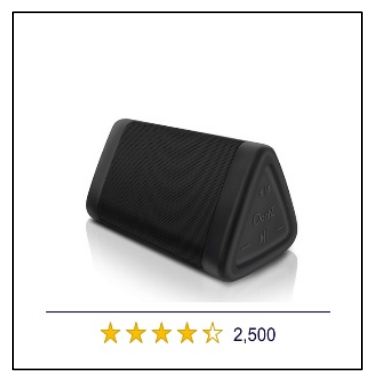

Xcentz

How likely are you to purchase the following brands the next time you consider purchasing a Bluetooth speaker?

\begin{tabular}{|c|c|c|c|c|c|}
\hline & Extremely unlikely & Somewhat unlikely & $\begin{array}{l}\text { Neither likely nor } \\
\text { unlikely }\end{array}$ & Somewhat likely & Extremely likely \\
\hline DigiShack & $\bigcirc$ & $\bigcirc$ & $\bigcirc$ & $\bigcirc$ & $\bigcirc$ \\
\hline JBL & $\bigcirc$ & $\bigcirc$ & $\bigcirc$ & $\bigcirc$ & $\bigcirc$ \\
\hline Oontz & $\bigcirc$ & $\bigcirc$ & $\bigcirc$ & $\bigcirc$ & $\bigcirc$ \\
\hline Anker & $\bigcirc$ & $\bigcirc$ & $\bigcirc$ & $\bigcirc$ & $\bigcirc$ \\
\hline
\end{tabular}


Please click on the hyperlink below and decide which product you would prefer to purchase, then select it from the list below.

https://storebrandz.myshopify.com/collections/universal-adapters-dshh

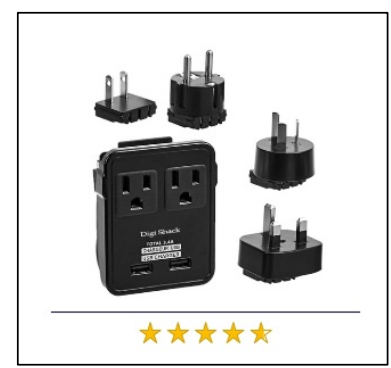

AmazonBasics

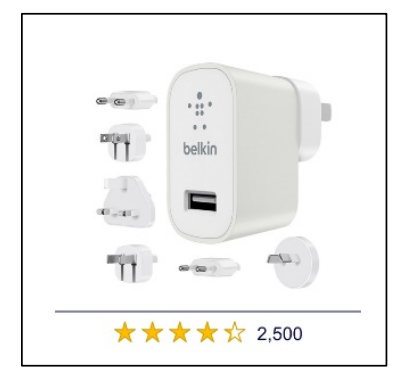

Anker

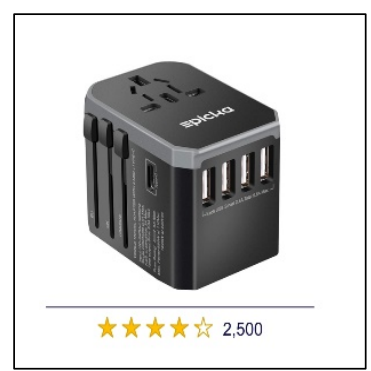

Belkin

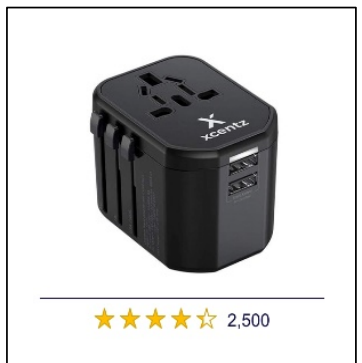

Xcentz

How likely are you to purchase the following brands the next time you consider purchasing a Universal travel adapter?

\begin{tabular}{|c|c|c|c|c|c|}
\hline & $\begin{array}{l}\text { Extremely } \\
\text { unlikely }\end{array}$ & $\begin{array}{l}\text { Somewhat } \\
\text { unlikely }\end{array}$ & $\begin{array}{l}\text { Neither likely } \\
\text { nor unlikely }\end{array}$ & $\begin{array}{l}\text { Somewhat } \\
\text { likely }\end{array}$ & $\begin{array}{c}\text { Extremely } \\
\text { likely }\end{array}$ \\
\hline DigiShack & 0 & $\bigcirc$ & $\bigcirc$ & $\bigcirc$ & $\bigcirc$ \\
\hline Belkin & $\bigcirc$ & $\bigcirc$ & $\bigcirc$ & $\bigcirc$ & 0 \\
\hline Xcentz & $\bigcirc$ & $\bigcirc$ & $\bigcirc$ & $\bigcirc$ & $\bigcirc$ \\
\hline Epicka & 0 & $\bigcirc$ & $\bigcirc$ & $\bigcirc$ & $\bigcirc$ \\
\hline
\end{tabular}

Indicate the extent to which you agree with the following statements.

\begin{tabular}{c|ccccccc} 
& $\begin{array}{c}\text { Strongly } \\
\text { disagree }\end{array}$ & Disagree & $\begin{array}{c}\text { Somewhat } \\
\text { disagree }\end{array}$ & $\begin{array}{c}\text { Neither agree } \\
\text { nor disagree }\end{array}$ & $\begin{array}{c}\text { Somewhat } \\
\text { agree }\end{array}$ & $\begin{array}{c}\text { Agree } \\
\text { agree }\end{array}$ \\
\hline $\begin{array}{c}\text { DigiShack is } \\
\text { an e-retailer } \\
\text { with good } \\
\text { reputation }\end{array}$ & 0 & 0 & 0 & & & \\
\end{tabular}


In your opinion, what is the level of quality for the following products?

\begin{tabular}{|c|c|c|c|c|c|}
\hline & Extremely low & Somewhat low & $\begin{array}{c}\text { Neither high nor } \\
\text { low }\end{array}$ & Somewhat high & Extremely high \\
\hline DigiShack & $\bigcirc$ & $\bigcirc$ & O & $\bigcirc$ & $\bigcirc$ \\
\hline Anker & $\bigcirc$ & $\bigcirc$ & O & $\bigcirc$ & $\bigcirc$ \\
\hline Belkin & $\bigcirc$ & $\bigcirc$ & $\bigcirc$ & $\bigcirc$ & $\bigcirc$ \\
\hline Epicka & $\bigcirc$ & $\bigcirc$ & $\bigcirc$ & O & $\bigcirc$ \\
\hline $\mathrm{JBL}$ & $\bigcirc$ & 0 & 0 & 0 & 0 \\
\hline Oontz & $\bigcirc$ & 0 & 0 & 0 & $\bigcirc$ \\
\hline Xcentz & $\bigcirc$ & $\bigcirc$ & $\bigcirc$ & $\bigcirc$ & $\bigcirc$ \\
\hline
\end{tabular}

Using the scale given below, please indicate how you felt about online product information pages.

\begin{tabular}{|c|c|c|c|c|c|c|}
\hline $\begin{array}{c}\text { Extremely } \\
\text { negative } \\
(-3)\end{array}$ & $\begin{array}{c}\text { Very } \\
\text { negative } \\
(-2)\end{array}$ & $\begin{array}{l}\text { Negative } \\
(-1)\end{array}$ & Neutral & $\begin{array}{l}\text { Positive } \\
(+1)\end{array}$ & $\begin{array}{c}\text { Very } \\
\text { Positive } \\
(+2)\end{array}$ & $\begin{array}{c}\text { Extremely } \\
\text { positive } \\
(+3)\end{array}$ \\
\hline
\end{tabular}




\begin{tabular}{|c|c|c|c|c|c|c|c|c|}
\hline & $1(1)$ & $2(2)$ & $3(3)$ & $4(4)$ & $5(5)$ & $6(6)$ & $7(7)$ & \\
\hline Unhappy & $\bigcirc$ & $\bigcirc$ & $\bigcirc$ & 0 & 0 & 0 & 0 & Happy \\
\hline Annoyed & 0 & 0 & $\bigcirc$ & 0 & 0 & 0 & 0 & Pleased \\
\hline $\begin{array}{c}\text { Dis- } \\
\text { satisfied }\end{array}$ & $\bigcirc$ & $\bigcirc$ & $\bigcirc$ & $\bigcirc$ & $\bigcirc$ & $\bigcirc$ & $\bigcirc$ & Satisfied \\
\hline Melancholic & $\bigcirc$ & $\bigcirc$ & $\bigcirc$ & $\bigcirc$ & $\bigcirc$ & $\bigcirc$ & $\bigcirc$ & contended \\
\hline Despairing & O & 0 & 0 & 0 & 0 & 0 & O & Hopeful \\
\hline Bored & 0 & $\bigcirc$ & $\bigcirc$ & 0 & $\bigcirc$ & $\bigcirc$ & ○ & Relaxed \\
\hline Sluggish & 0 & 0 & $\bigcirc$ & 0 & 0 & 0 & O & Frenzied \\
\hline Dull & $\bigcirc$ & $\bigcirc$ & $\bigcirc$ & ○ & $\bigcirc$ & $\bigcirc$ & 0 & Jittery \\
\hline Unaroused & 0 & 0 & 0 & 0 & 0 & 0 & O & aroused \\
\hline Relaxed & $\bigcirc$ & $\bigcirc$ & $\bigcirc$ & $\bigcirc$ & $\bigcirc$ & $\bigcirc$ & $\bigcirc$ & Stimulated \\
\hline Calm & $\bigcirc$ & $\bigcirc$ & $\bigcirc$ & $\bigcirc$ & $\bigcirc$ & $\bigcirc$ & $\bigcirc$ & Excited \\
\hline Sleepy & 0 & 0 & 0 & 0 & 0 & 0 & O & $\begin{array}{c}\text { Wide } \\
\text { awake }\end{array}$ \\
\hline
\end{tabular}

What Gender do you identify with?

Male (1)

Female (2)

Other (3)

Prefer not to say (4)

What is your age?

Under 18 (1)

18-25 (2)

26-35 (3)

- $36-45$ (4)

- 46-55 (5)

$56+(6)$ 
What is your annual household income?

Less than $\$ 25,000$ (1)

$\$ 25,000-\$ 50,000(2)$

$\$ 50,000-100,000$ (3)

$\$ 100,000-200,000$ (4)

More than 200,000 (5)

Prefer not to say (6) 


\section{References}

Ailawadi, K. L., \& Harlam, B. (2004). An empirical analysis of the determinants of retail margins: the role of store-brand share. Journal of Marketing, 68(1), 147-165.

https://doi.org/10.1509/jmkg.68.1.147.24027.

Ailawadi, K. L., Gedenk, K., \& Neslin, S. (2003). Understanding competition between retailers and manufacturers: an integrated analysis of store brand and national brand deal usage. http://dx.doi.org/10.2139/ssrn.404641.

Ailawadi, K. L., Pauwels, K., \& Steenkamp, J. B. E. (2008). Private-label use and store loyalty. Journal of marketing, 72(6), 19-30. https://doi.org/10.1509/jmkg.72.6.019.

Akaah, I., \& Korgaonkar, P. (1988). A conjoint investigation of the relative importance of risk relievers in direct marketing. Journal of Advertising Research, 28(4), 38-.

Altıntaş, M. H., Kılıç, S., Senol, G., \& Isin, F. B. (2010). Strategic objectives and competitive advantages of private label products. International Journal of Retail \& Distribution Management, 38 (10), 773-788. https://doi.org/10.1108/09590551011076542.

Amblee, N., \& Bui, T. X. (2007). The impact of electronic-word-of-mouth on digital microproducts: an empirical investigation of Amazon shorts.

http://aisel.aisnet.org/ecis2007/27.

Amrouche, N., \& Zaccour, G. (2007). Shelf-space allocation of national and private brands. European Journal of Operational Research, 180(2), 648-663.

https://doi.org/10.1016/j.ejor.2006.05.008.

Anderson, C. (2012). The impact of social media on lodging performance. Center for Hospitality Research Publications. https://hdl.handle.net/1813/71194.

Anselmsson, J., Johansson, U., \& Persson, N. (2007). Understanding price premium for grocery products: a conceptual model of customer-based brand equity. Journal of Product \& Brand Management. 16(6), 401-414. https://doi.org/10.1108/10610420710823762.

Arce-Urriza, M., \& Cebollada, J. (2012). Private labels and national brands across online and offline channels. Management Decision, 17721789. https://doi.org/10.1108/00251741211279594.

Arce-Urriza, M., \& Cebollada, J. (2018). Assessing the success of private labels online: differences across categories in the grocery industry. Electronic Commerce Research, 18(4), 719-753. https://doi.org/10.1007/s10660-017-9281-8.

Bagozzi, R. P. (1986). Attitude formation under the theory of reasoned action and a purposeful behaviour reformulation. British Journal of Social Psychology,25(2), 95-107. https://doi.org/10.1111/j.2044-8309.1986.tb00708. 
Balabanis, G., \& Craven, S. (1997). Consumer confusion from own brand lookalikes: an exploratory investigation. Journal of marketing management, 13(4), 299-313. https://doi.org/10.1080/0267257X.1997.9964474

Baltas, G. (2003). A combined segmentation and demand model for store brands. European Journal of Marketing, 37 (10), 1499-1513. https://doi.org/10.1108/03090560310487211.

Baltas, G., \& Doyle, P. (1998). An empirical analysis of private brand demand recognising heterogeneous preferences and choice dynamics. Journal of the Operational Research Society, 49(8), 790-798. https://doi.org/10.1057/palgrave.jors.2600591.

Batra, R., \& Sinha, I. (2000). Consumer-level factors moderating the success of private label brands. Journal of retailing, 76(2), 175-191. https://doi.org/10.1016/S0022-4359(00)00027-0.

Becherer, R. C., \& Richard, L. M. (1978). Self-monitoring as a moderating variable in consumer behavior. Journal of Consumer Research, 5(3), 159-162.

https://doi.org/10.1086/208726.

Berges-Sennou, F., Bontems, P., \& Réquillart, V. (2004). Economics of private labels: A survey of literature. Journal of Agricultural \& Food Industrial Organization, 2(1), 1-23. https:// doi.org/ 10.2202/1542-0485.1037.

Bitner, M. J. (1992). Servicescapes: The impact of physical surroundings on customers and employees. Journal of marketing, 56(2), 57-71.

https://doi.org/10.1177/002224299205600205.

Bonanno, A., \& Rigoberto, A. L. (2005). Private label expansion and supermarket milk prices. Journal of Agricultural \& Food Industrial Organization, 3(1), 1-16.

Bontems, P., Monier-Dilhan, S., \& Requillart, V. (1999). Strategic effects of private labels. European Review of Agricultural Economics, 26(2), 147-

165. https://doi.org/10.1093/erae/26.2.147.

Bontis, N., Bart, C., Wakefield, P., Booker, L. D., \& Serenko, A. (2007). The mediating effect of organizational reputation on customer loyalty and service recommendation in the banking industry. Management decision, 45(9), 1426-1445.

https://doi.org/10.1108/00251740710828681.

Brüggemann, P., Olbrich, R., \& Schultz, C. D. (2020, June). Competition between National Brands and Private Labels: Determinants of the Market Share of National Brands. In International Conference on Advances in National Brand and Private Label Marketing (3949). Springer, Cham. https://doi.org/10.1007/978-3-030-47764-6_5.

Brynjolfsson, E., \& Smith, M. D. (2000). Frictionless commerce? A comparison of Internet and conventional retailers. Management science, 46(4), 563-585.

https://doi.org/10.1287/mnsc.46.4.563.12061. 
Burger, P. C., \& Schott, B. (1972). Can private brand buyers be identified?. Journal of Marketing Research, 9(2), 219-222. https://doi.org/10.1177/002224377200900217.

Burt, S. (2000). The strategic role of retail brands in British grocery retailing. European Journal of Marketing, 34 (8), 875-890. https://doi.org/10.1108/03090560010331351.

Burt, S., \& Davies, K. (2010). From the retail brand to the retail-er as a brand: themes and issues in retail branding research. International Journal of Retail \& Distribution Management, 38(11/12), 865-878. https://doi.org/10.1108/09590551011085957.

Burton, S., Lichtenstein, D. R., Netemeyer, R. G., \& Garretson, J. A. (1998). A scale for measuring attitude toward private label products and an examination of its psychological and behavioural correlates. Journal of the academy of marketing science, 26(4), 293-306. https://doi.org/10.1177/0092070398264003.

Bushman, B. J. (1993). What's in a name? The moderating role of public self-consciousness on the relation between brand label and brand preference. Journal of Applied Psychology, 78(5), 857-861. https://doi.org/10.1037/0021-9010.78.5.857.

Business.com. (2020, April 15). The 10 Largest E-commerce Markets in the World by Country. https://www.business.com/articles/10-of-the-largest-ecommerce-markets-in-the-worldb/\#: :text=2.-,United\%20States,commerce\%20market $\% 20$ in $\% 20$ the $\% 20$ world.

Chan, T. K., Cheung, C. M., \& Lee, Z. W. (2017). The state of online impulse-buying research: A literature analysis. Information \& Management, 54(2), 204-217.

https://doi.org/10.1016/j.im.2016.06.001.

Chen, C. C., \& Yao, J. Y. (2018). What drives impulse buying behaviours in a mobile auction? The perspective of the Stimulus-Organism-Response model. Telematics and Informatics, 35(5), 1249-1262. https://doi.org/10.1016/j.tele.2018.02.007.

Chen, C. Y., Mathur, P., \& Maheswaran, D. (2014). The effects of country-related affect on product evaluations. Journal of Consumer research, 41(4), 1033-1046.

https://doi.org/10.1086/678194.

Chen, Y., \& Xie, J. (2008). Online consumer review: Word-of-mouth as a new element of marketing communication mix. Management science, 54(3), 477-491.

https://doi.org/10.1287/mnsc.1070.0810.

Cheng, J. M. S., Chen, L. S. L., Lin, J. Y. C., \& Wang, E. S. T. (2007). Do consumers perceive differences among national brands, international private labels and local private labels? The case of Taiwan. Journal of Product \& Brand Management, 16(6), 368376. https://doi.org/10.1108/10610420710823735.

Chevalier, J. A., \& Mayzlin, D. (2006). The effect of word of mouth on sales: Online book reviews. Journal of marketing research, 43(3), 345-354.

https://doi.org/10.1509/jmkr.43.3.345. 
Chuang, S. C., \& Yen, H. R. (2007). The impact of a product's country-of-origin on compromise and attraction effects. Marketing Letters, 18(4), 279-291.

https://doi.org/10.1007/s11002-007-9017-y.

Clow, K. E. \& James, K. E. (2014). Experimental research. In Essentials of marketing research: Putting research into practice, (192-222). SAGE Publications, Inc., https://www.doi.org/10.4135/9781483384726.

Colombo, R., \& Morrison, D. (1989). A Brand Switching Model with Implications for Marketing Strategies-Reply. Marketing Science, 8(1), 106-106.

Coppola, D. (2021, Feb 25). Private label share of supermarkets' sales volume in Europe 2020, by country. https://www.statista.com/statistics/1194649/private-label-share-oftotalsupermarkets-sales-volume-europe/.

Corstjens, M., \& Lal, R. (2000). Building store loyalty through store brands. Journal of marketing research, 37(3), 281-291. https://doi.org.1509/jmkr.37.3.281.18781.

Cui, G., Lui, H. K., \& Guo, X. (2012). The effect of online consumer reviews on new product sales. International Journal of Electronic Commerce, 17(1), 39-58.

https://doi.org/10.2753/JEC1086-4415170102.

Cuneo, A., Milberg, S.J., Benavente, J.M., \& Palacios-Fenech, J. (2015). The growth of private label brands: a worldwide phenomenon? . Journal of International Marketing, 23(1), 72-90.

Dawar, N., \& Parker, P. (1994). Marketing universals: Consumers' use of brand name, price, physical appearance, and retailer reputation as signals of product quality. Journal of marketing, 58(2), 81-95. https://doi.org/10.1177/002224299405800207.

Dawes, J., \& Nenycz-Thiel, M. (2014). Comparing retailer purchase patterns and brand metrics for in-store and online grocery purchasing. Journal of Marketing Management, 30(3-4), 364382. https://doi.org/10.1080/0267257X.2013.813576.

Dawson, S., \& Kim, M. (2009). External and internal trigger cues of impulse buying online. Direct Marketing: An International Journal, 3(1), 20-34. https://doi.org/10.1108/17505930945714.

Dellarocas, C. (2003). The digitization of word of mouth: Promise and challenges of online feedback mechanisms. Management science, 49(10), 1407-1424.

https://doi.org/10.1287/mnsc.49.10.1407.17308.

Dellarocas, C., Zhang, X. M., \& Awad, N. F. (2007). Exploring the value of online product reviews in forecasting sales: The case of motion pictures. Journal of Interactive marketing, 21(4), 23-45. https://doi.org/10.1002/dir.20087. 
Devlin, D., Birtwistle, G., \& Macedo, N. (2003). Food retail positioning strategy: a means-end chain analysis. British Food Journal, 105(9), 653670. https://doi.org/10.1108/00070700310497372.

Dhar, R., \& Simonson, I. (2003). The effect of forced choice on choice. Journal of marketing research, 40(2), 146-160. https://doi.org/10.1509/jmkr.40.2.146.19229.

Diallo, M. F. (2012). Effects of store image and store brand price-image on store brand purchase intention: Application to an emerging market. Journal of Retailing and Consumer Services, 19(3), 360-367. https://doi.org/10.1016/j.jretconser.2012.03.010.

Diamantopoulos, A., Florack, A., Halkias, G., \& Palcu, J. (2017). Explicit versus implicit country stereotypes as predictors of product preferences: Insights from the stereotype content model. Journal of International Business Studies, 48(8), 1023-1036. https://doi.org/10.1057/s41267-017-0085-9.

Dick, A., Jain, A., \& Richardson, P. (1995). Correlates of store brand proneness: some empirical observations. Journal of Product \& Brand Management, 4(4), 15-22. https://doi.org/10.1108/10610429510097663.

Dickinger, A., \& Mazanec, J. A. (2008, January). Consumers' preferred criteria for hotel online booking. In ENTER (pp. 244-254).

Donovan, R. J., \& Rossiter J. R., (1982). Store atmosphere: an environmental psychology approach. Journal of retailing, 58(1), 34-57.

Donovan, R. J., Rossiter, J. R., Marcoolyn, G., \& Nesdale, A. (1994). Store atmosphere and purchasing behavior. Journal of retailing, 70(3), 283-294. https://doi.org/10.1016/00224359(94)90037-X.

Duan, W., Gu, B., \& Whinston, A. B. (2008). Do online reviews matter? An empirical investigation of panel data. Decision support systems, 45(4), 1007-1016.

https://doi.org/10.1016/j.dss.2008.04.001.

Dubelaar, C., Chow, G., \& Larson, P. D. (2001). Relationships between inventory, sales and service in a retail chain store operation. International journal of physical distribution \& logistics management, 31(2), 96-108. https://doi.org/10.1108/09600030110387480.

Dudley, R. (2020, June 6). Amazon's New Competitive Advantage: Putting Its Own Products First. https://www.propublica.org/article/amazons-new-competitive-advantage-putting-itsown-products-first.

Ehrenberg, A. S. (2000). Repeat buying. Journal of Empirical Generalisations in Marketing Science, 5(2).

eMarketer. (2020). Ecommerce powers consumer electronics sales.

https://www.emarketer.com/contentconsumer-electronics-sales-powered-by-ecommerce. 
Enberg, J. (2018). Amazon around the World. eMarketer.

https://www.emarketer.com/content/amazon-around-the-world.

Engler, T. H., Winter, P., \& Schulz, M. (2015). Understanding online product ratings: A customer satisfaction model. Journal of Retailing and Consumer Services, 27, 113-120. https://doi.org/10.1016/j.jretconser.2015.07.010.

Eroglu, S. A., Machleit, K. A., \& Davis, L. M. (2003). Empirical testing of a model of online store atmospherics and shopper responses. Psychology \& marketing, 20(2), 139-150. https://doi.org/10.1002/mar.10064.

Eroglu, S.A., Machleit, K.A., Davis, L.M., (2001). Atmospheric qualities of online retailing: A conceptual model and implications. Journal of Business Research, 54(2), 177-184. https://doi.org/10.1016/S0148-2963(99)00087-9.

Estárico, E. H., Medina, L. F., \& Marrero, S. M. (2012). Una aproximación a la reputación en línea de los establecimientos hoteleros españoles. Papers de turisme, (52), 63-88.

Filieri, R., McLeay, F., Tsui, B., \& Lin, Z. (2018). Consumer perceptions of information helpfulness and determinants of purchase intention in online consumer reviews of services. Information \& Management, 55(8), 956-970.

https://doi.org/10.1016/j.im.2018.04.010.

Flanagin, A. J., Metzger, M. J., Pure, R., Markov, A., \& Hartsell, E. (2014). Mitigating risk in ecommerce transactions: perceptions of information credibility and the role of user-generated ratings in product quality and purchase intention. Electronic Commerce Research, 14(1), 1-23. https://doi.org/10/1007/s10660-014-9139-2.

Floor, K. (2006). Branding a store: How to build successful retail brands in a changing marketplace. Kogan Page Publishers.

Formplus. (2020, December 04). Descriptive Research Designs: Types, Examples \& Methods. https://www.formpl.us/blog/descriptive-research.

Fornell, C. (1992). A national customer satisfaction barometer: The Swedish experience. Journal of marketing, 56(1), 6-21.

https://doi.org/10.1177/002224299205600103.

Fornell, C., Johnson, M. D., Anderson, E. W., Cha, J., \& Bryant, B. E. (1996). The American customer satisfaction index: nature, purpose, and findings. Journal of marketing, 60(4), 7-18. https://doi.org/10.1177/002224299606000403.

Fournier, L. S. A. (1996). Les marques de distributeurs. Libre Service Actualities, 14, 10-15.

Frank, R. E., \& Boyd Jr, H. W. (1965). Are private-brand-prone grocery customers really different?. Journal of Advertising Research, 5(4), 27-35. 
Gaedeke, R. 1973. "Consumer attitudes towards products 'Made in' developing countries," Journal of Retailing 49: 14-24.

Garrett, T. C., Lee, S., \& Chu, K. (2017). A store brand's country-of-origin or store image: what matters to consumers?. International Marketing Review, 34(2) 272292. https://doi.org/10.1108/IMR-03-2015-0083

Geyskens, I., Gielens, K., \& Gijsbrechts, E. (2010). Proliferating private-label portfolios: How introducing economy and premium private labels influences brand choice. Journal of Marketing Research, 47(5), 791-807. https://doi/10.1509/jmkr.47.5.791.

Ghose, A., \& Ipeirotis, P. G. (2006, December). Designing ranking systems for consumer reviews: The impact of review subjectivity on product sales and review quality. In Proceedings of the 16th annual workshop on information technology and systems (Vol. 303, No. 10).

Gómez, M., \& Benito, N. R. (2008). Manufacturer's characteristics that determine the choice of producing store brands. European Journal of Marketing, 42(1/2), 154-177.

https://doi.org/10.1108/03090560810840952.

Gomez, M., \& Rubio, N. (2010). Re-thinking the relationship between store brand attitude and store brand loyalty: a simultaneous approach. The International Review of Retail, Distribution and Consumer Research, 20(5), 515-534. https://doi.org/10.1080/09593969.2010.520507.

Gómez-Suárez, M., Quiñones, M., \& Yagüe-Guillén, M. J. (2017). Private label research: A review of consumer purchase decision models. Advances in national brand and private label marketing, 165-172. https://doi.org/10.1007/978-3-319-59701-0_17.

Grewal, D., Krishnan, R., Baker, J., \& Borin, N. (1998). The effect of store name, brand name and price discounts on consumers' evaluations and purchase intentions. Journal of retailing, 74(3), 331-352. https://doi.org/10.1016/S0022-4359(99)80099-2.

Ha, H. Y. (2004). Factors influencing consumer perceptions of brand trust online. Journal of $\begin{array}{lllll}\text { product } \quad \& \quad \text { brand management. } & 13(5), & 329 & -342 .\end{array}$ https://doi.org/10.1108/10610420410554412.

Hansen, K., Singh, V., \& Chintagunta, P. (2006). Understanding store-brand purchase behavior across categories. Marketing Science, 25(1), 75-90. https://doi.org/10.1287/mksc.1050.0151.

Hartman, K. B., \& Spiro, R. L. (2005). Recapturing store image in customer-based store equity: a construct conceptualization. Journal of Business research,58(8), 1112-1120. https://doi.org/10.1016/j.jbusres.2004.01.008.

Herstein, R., Drori, N., Berger, R., \& Barnes, B. R. (2017). Exploring the gap between policy and practice in private branding strategy management in an emerging market. International Marketing Review, 34 (4), 559-578. https://doi.org/10.1108/IMR-05-2014-0188. 
Herz, M. F., \& Diamantopoulos, A. (2013). Activation of country stereotypes: automaticity, consonance, and impact. Journal of the Academy of Marketing Science, 41(4), 400-417. https://doi.org/10.1007/s11747-012-0318-1.

Hoch, S. J. (1996). How should national brands think about private labels?. MIT Sloan Management Review, 37(2), 89. https://search.proquest.com/scholarly-journals/how-shouldnational-brands-think-about-private/docview/224972208/se-2?accountid=14782.

Hoch, S. J., \& Banerji, S. (1993). When do private labels succeed?. MIT Sloan Management Review, 34(4), 57. https://search.proquest.com/scholarly-journals/when-do-private-labelssucceed/docview/224960867/se-2?accountid=14782.

Hong, S., \& Wyer, R. (1989). Effects of country-of-origin and product-attribute information on product evaluation: an information processing perspective. The Journal of Consumer Research, 16(2), 175-187. https://doi.org/10.1086/209206.

Hu, M., \& Liu, B. (2004, August). Mining and summarizing customer reviews. In Proceedings of the tenth ACM SIGKDD international conference on Knowledge discovery and data mining (pp. 168-177). https://doi.org/10.1145/1014052.1014073.

Huang, M. H., Jones, E., \& Hahn, D. E. (2007). Determinants of price elasticities for private labels and national brands of cheese. Applied Economics, 39(5), 553-563. https://doi.org/10.1080/00036840500439069.

Huang, Y., \& Huddleston, P. (2009). Retailer premium own-brands: creating customer loyalty through own-brand products advantage. International Journal of Retail \& Distribution Management, 37(11), 975-992. https://doi.org/10.1108/09590550910999389.

Huang, Z. and Feng, T. (2020), Money-back guarantee and pricing decision with retailer's store brand. Journal of Retailing and Consumer Services. 52, 101897.

Hultman, M., Opoku, R. A., Salehi-Sangari, E., Oghazi, P., \& Bui, Q. T. (2008). Private label competition: the perspective of Swedish branded goods manufacturers. Management Research News, 31(2), 125-141. https://doi.org/10.1108/01409170810846849.

Hyman, M. R., Kopf, D. A., \& Lee, D. (2010). Review of literature-Future research suggestions: Private label brands: Benefits, success factors and future research. Journal of Brand Management, 17(5), 368-389. https://doi.org/10.1057/bm.2009.33.

Information Resources Inc. (2007), Private Label 2007: U.S. \& Europe Retail Branding Strategies Capture Market Potential. Chicago: Information Resources Inc.

Jang, S., \& Moutinho, L. (2019). Do price promotions drive consumer spending on luxury hotel services? The moderating roles of room price and user-generated content. International Journal of Hospitality Management, 78, 27-35. https://doi.org/10.1016/j.ijhm.2018.11.010.

Jang, S., Chung, J., \& Rao, V. R. (2019). The importance of functional and emotional content in online consumer reviews for product sales: Evidence from the mobile gaming market. Journal of Business Research. https://doi.org/10.1016/j.jbusres.2019.09.027. 
Jin, B., Park, J. Y., \& Kim, J. (2008). Cross-cultural examination of the relationships among firm reputation, e-satisfaction, e-trust, and e-loyalty. International Marketing Review, 25(3), 324-337. https://doi.org/10.1108/02651330810877243.

Jiuan Tan, S. (1999). Strategies for reducing consumers' risk aversion in Internet shopping. The Journal of Consumer Marketing, 16(2), 163-180.

https://doi.org/10.1108/07363769910260515.

Kalwani, M. U., \& Narayandas, N. (1995). Long-term manufacturer-supplier relationships: do they pay off for supplier firms?. Journal of marketing, 59(1), 1-16.

https://doi.org/10.1177\%2F00222429950590010.

Kapferer, J. N. (1995). Brand confusion: Empirical study of a legal concept. Psychology \& Marketing, 12(6), 551-568. https://doi.org/10.1002/mar.4220120607.

Kaur, S., Lal, A. K., \& Bedi, S. S. (2017). Do vendor cues influence purchase intention of online shoppers? An empirical study using SOR framework. Journal of Internet Commerce, 16(4), 343-363. https://doi.org/10.1080/15332861.2017.1347861.

Kim, J., \& Lennon, S. J. (2013). Effects of reputation and website quality on online consumers' emotion, perceived risk and purchase intention. Journal of Research in Interactive Marketing, 7(1), 33-56. https://doi.org/10.1108/17505931311316734.

Klein, J. G., Ettenson, R., \& Morris, M. D. (1998). The animosity model of foreign product purchase: An empirical test in the People's Republic of China. Journal of marketing, 62(1), 89100. https://doi.org/10.1177/002224299806200108.

Konuk, F. A. (2018). The role of store image, perceived quality, trust and perceived value in predicting consumers' purchase intentions towards organic private label food. Journal of Retailing and Consumer Services, 43, 304-310.

https://doi.org/10.1016/j.jretconser.2018.04.011.

Koo, D.M., \& Ju, S.H. (2010). The interactional effects of atmospherics and perceptual curiosity on emotions and online shopping intention. Computers in Human Behavior, 26(3), 377-388. https://doi.org/10.1016/j.chb.2009.11.009.

Kotha, S., Rajgopal, S., \& Rindova, V. (2001). Reputation building and performance: An empirical analysis of the top-50 pure internet firms. European Management Journal, 19(6), 571-586. https://doi.org/10.1016/S0263-2373(01)00083-4.

KPMG. (2020). The online private label growth paradigm. https://assets.kpmg/content/dam/kpmg/in/pdf/2020/02/online-private-label.pdf.

Kühn, S. W., \& Petzer, D. J. (2018). Fostering purchase intentions toward online retailer websites in an emerging market: An SOR perspective. Journal of Internet Commerce, 17(3), 255-282. https://doi.org/10.1080/15332861.2018.1463799. 
Kumar, N., \& Steenkamp, J. E. M. (2007). Private Label Strategy: How to Meet the Store Brand Challenge. Harvard Business School press.

Kumar, N., \& Steenkamp, J.-B. E. M. (2013). Brand breakout: How emerging market brands will go global. New York: Palgrave Macmillan.

Kumar, S., \& Chandra, B. (2020). Consumer purchase intention towards private label brands of virtual retailers: evidence from a developing nation. International Journal of Electronic Marketing and Retailing, 11(2), 161-183. https://doi.org/10.1504/IJEMR.2020.106843.

Laloggia, J. (2018). Americans have mixed views of Mexico, 'warmer'feelings toward Canada. Pew Research Centre. https://www.pewresearch.org/fact-tank/2018/08/28/americans-havemixed-views-of-mexico-warmer-feelings-toward-canada/.

Lee, W. N., Yun, T., \& Lee, B. K. (2005). The role of involvement in country-of-origin effects on product evaluation: Situational and enduring involvement. Journal of International Consumer Marketing, 17(2-3), 51-72. https://doi.org/10.1300/J046v17n02_04.

Li, Z. G., Murray, L. W., \& Scott, D. (2000). Global sourcing, multiple country-of-origin facets, and consumer reactions. Journal of Business Research, 47(2), 121-133. https://doi.org/10.1016/S0148-2963(98)00061-7.

Liefeld, J. P. (1993). Experiments on country-of-origin effects: review and meta-analysis of effect size. In N. Papadopoulos \& L. A. Heslop (Eds.), Product-country image: impact and role in international marketing (pp. 117-156). New York: International Business Press.

Lim, A., Zhan, Q. and Rodrigues, B. (2002), “A heuristic for shelf-space decision support in the retail industry", SMU Conference Papers Series, Paper No. 6, August.

Lin, C. C., Wu, H. Y., \& Chang, Y. F. (2011). The critical factors impact on online customer satisfaction. Procedia Computer Science, 3, 276-281.

https://doi.org/10.1016/j.procs.2010.12.047.

Lipsman, A. (2019, Jun 27). Global Ecommerce 2019: Ecommerce Continues Strong Gains Amid Global Economic Uncertainty. https:/www.emarketer.com/content/global-ecommerce2019.

Litvin, S. W., Goldsmith, R. E., \& Pan, B. (2008). Electronic word-of-mouth in hospitality and tourism management. Tourism management, 29(3), 458-468.

https://doi.org/10.1016/j.tourman.2007.05.011.

Liu, B., Song, M., Yang, G., Cheng, S., \& Li, M. (2020). Stimulus organism response model based analysis on consumers' online impulse buying behaviour. The International Journal of Electrical Engineering \& Education. https://doi:10.1177/0020720920940585.

Lwin, M. O., \& Williams, J. D. (2006). Promises, promises: how consumers respond to warranties in internet retailing. Journal of consumer Affairs, 40(2), 236-260.

https://doi.org/10.1111/j.1745-6606.2006.00057. 
Magnusson, P., \& Westjohn, S. A. (2011). 15 Is there a country-of-origin theory?. Handbook of research in international marketing, 292.

Magnusson, P., Westjohn, S. A., \& Sirianni, N. J. (2019). Beyond country image favorability: How brand positioning via country personality stereotypes enhances brand evaluations. Journal of International Business Studies, 50(3), 318-338.

https://doi.org/10.1057/s41267-018-0175-3.

Maheswaran, D., \& Chen, C. Y. (2009). Nation Equity: Country-of Origin Effects and Globalization. The SAGE Handbook of International Marketing, 91-113.

Manganari, E. E., Siomkos, G. J., \& Vrechopoulos, A. P. (2009). Store atmosphere in web retailing. European Journal of Marketing, 43(9/10), 1140-

1153. https://doi.org/10.1108/03090560910976401.

Marker Editors. (2020, August 6). The Stealthy Rise of Amazon's Private Label Empire, By the Numbers. https://marker.medium.com/the-stealthy-rise-of-amazons-private-label-empire-by-thenumbers-39875e079ed.

Martineau, P. (1958). The personality of the retail store. Boston, Mass: Graduate School of Business Administration, Harvard University.

Martinez, E., \& Montaner, T. (2008). Characterisation of Spanish store brand consumers. International Journal of Retail \& Distribution Management, 36(6), 477493. https://doi.org/10.1108/09590550810873947.

Mauri, A. G., \& Minazzi, R. (2013). Web reviews influence on expectations and purchasing intentions of hotel potential customers. International journal of hospitality management, 34 , 99-107. https://doi.org/10.1016/j.ijhm.2013.02.012.

MBA Skool Team. (2018, January 22). What is Experimental Research? MBA Skool. https://www.mbaskool.com/business-concepts/marketing-and-strategy-terms/1867experimental-research.html.

McGoldrick, P. (2002), Retail Marketing, McGraw-Hill.

Mills, D. E. (1995). Why retailers sell private labels. Journal of Economics \& Management Strategy, 4(3), 509-528. https://doi.org/10.1111/j.1430-9134.1995.00509.

Miranda, M. J., \& Joshi, M. (2003). Australian retailers need to engage with private labels to achieve competitive difference. Asia Pacific Journal of Marketing and Logistics, 15 (3), 3447. https://doi.org/10.1108/13555850310764999.

Mishra, S., Malhotra, G., \& Saxena, G. (2020). In-store marketing of private labels: applying cue utilisation theory. International Journal of Retail \& Distribution Management, 49(1), $145-$ 163. https://doi.org/10.1108/IJRDM-04-2020-0152. 
Mitchell, V. W., \& Greatorex, M. (1993). Risk perception and reduction in the purchase of consumer services. Service Industries Journal, 13(4), 179-200.

https://doi.org/10.1080/02642069300000068.

Mitchell, V. W., \& McGoldrick, P. J. (1996). Consumer's risk-reduction strategies: a review and synthesis. International Review of Retail, Distribution and Consumer Research, 6(1), 133. https://doi.org/10.1080/09593969600000001.

Mohapatra, S. (2013). E-commerce Strategy. In E-Commerce Strategy (pp. 155-171). Springer, Boston, MA. https://doi.org/10.1007/978-1-4614-4142-7_7.

Morris, D. (1979). The strategy of own brands. European Journal of Marketing, 13(2), 59-78.

Morris, D., \& Nightingale, J. (1980). Why should firms manufacture retailer brands?. Managerial and Decision Economics, 1(3), 132-137.

https://doi.org/10.1002/mde.4090010306.

Mosteller, J., Donthu, N., \& Eroglu, S. (2014). The fluent online shopping experience. Journal of Business Research, 67(11), 2486-2493. https://doi.org/10.1016/j.jbusres.2014.03.009.

Mudambi, S. M., \& Schuff, D. (2010). What makes a helpful review? A study of customer reviews on Amazon.com. MIS Quarterly, 34(1), 185-200.

Myers, J. G. (1967). Determinants of private brand attitude. Journal of marketing Research, 4(1), 73-81. https://doi.org/10.1177/002224376700400110.

Narasimhan, C., \& Wilcox, R. T. (1998). Private labels and the channel relationship: a crosscategory analysis. The journal of business, 71(4), 573-600. https://doi.org/10.1086/209757.

Nenycz-Thiel, M. (2011). Private labels in Australia: A case where retailer concentration does not predicate private labels share. Journal of Brand Management, 18(8), 624-633. https://doi.org/10.1057/bm.2010.57.

Nenycz-Thiel, M., \& Romaniuk, J. (2015). Buying of private labels across categories: how far is too far?. In Advances in National Brand and Private Label Marketing (pp. 35-42). Springer, Cham. https://doi.org/10.1007/978-3-319-20182-5_4.

Nenycz-Thiel, M., \& Romaniuk, J. (2016). Understanding premium private labels: A consumer categorisation approach. Journal of Retailing and Consumer Services, 29, 22-30.

https://doi.org/10.1016/j.jretconser.2015.10.008.

Nielsen, 2014. The State of Private Labels around the World. https://www.nielsen.com/wpcontent/uploads/sites/3/2019/04/state-of-private-label-around-the-world-niv-2014.pdf.

Nielsen, 2018. The Rise and Rise Again of Private Label.

https://www.nielsen.com/nz/en/insights/report/2018/the-rise-and-rise-again-of-private-label. 
Nogales, A. F., \& Suarez, M. G. (2005). Shelf space management of private labels: a case study in Spanish retailing. Journal of retailing and consumer services, 12(3), 205-216. https://doi.org/10.1016/j.jretconser.2004.06.004

O'Dea, S. (2021, Mar 1). IPhone users as share of smartphone users in the United States 20142021. Statista. https://www.statista.com/statistics/236550/percentage-of-us-population-thatown-a-iphone-smartphone/.

Olbrich, R., Jansen, H. C., \& Hundt, M. (2017). Effects of pricing strategies and product quality on private label and national brand performance. Journal of Retailing and Consumer Services, 34, 294-301. https://doi.org/10.1016/j.jretconser.2016.01.012.

Olson, J, C. (1972). Cue Utilization of the Quality Perception Process: A Cognitive Model and an Empirical Test, unpublished doctoral dissertation, Purdue University.

Olson, J. C., \& Jacoby, J. (1972). Cue utilization in the quality perception process. ACR Special Volumes. 167-179.

Omar, O. E. (1996). Grocery purchase behaviour for national and own-label brands. Service Industries Journal, 16(1), 58-66. https://doi.org/10.1080/02642069600000006

Oubina, J., Rubio, N., \& Yagüe, M. J. (2006). Strategic management of store brands: an analysis from the manufacturer's perspective. International Journal of Retail \& Distribution Management, 34(10), 742-760. https://doi.org/10.1108/09590550610691338.

Pang, B., Lee, L., \& Vaithyanathan, S. (2002). Thumbs up? Sentiment Classification using Machine Learning Techniques.

Pappu, R., Quester, P. G., \& Cooksey, R. W. (2007). Country image and consumer-based brand equity: relationships and implications for international marketing. Journal of International Business Studies, 38(5), 726-745. https://doi.org/10.1057/palgrave.jibs.8400293.

Parameswaran, R., \& Pisharodi, R. M. (2002). Assimilation effects in country image research. International Marketing Review, 19(3), 259-278.

https://doi.org/10.1108/02651330210430695.

Park, C., \& Lee, T. M. (2009). Antecedents of online reviews' usage and purchase influence: An empirical comparison of US and Korean consumers. Journal of Interactive Marketing, 23(4), 332-340. https://doi.org/10.1016/j.intmar.2009.07.001.

Park, D. H., Lee, J., \& Han, I. (2007). The effect of on-line consumer reviews on consumer purchasing intention: The moderating role of involvement. International journal of electronic commerce, 11(4), 125-148. https://doi.org/10.2753/JEC1086-4415110405.

Parsons, A. G., Ballantine, P. W., \& Wilkinson, H. (2012). Country-of-origin and private-label merchandise. Journal of Marketing Management, 28(5-6), 594-608.

https://doi.org/10.1080/0267257X.2010.549197. 
Peng, C., \& Kim, Y. G. (2014). Application of the stimuli-organism-response (SOR) framework to online shopping behavior. Journal of Internet Commerce, 13(3-4), 159-176. https://doi.org/10.1080/15332861.2014.944437.

Peterson, R. A., \& Jolibert, A. J. (1995). A meta-analysis of country-of-origin effects. Journal of International business studies, 26(4), 883-900.

https://doi.org/10.1057/palgrave.jibs.8490824.

Philipsen, K. P., \& Kolind, J. (2012). Supplier and retailer collaboration over the creation of me-too and own brand private labels. Ledelse \& Erhvervsøkonomi, 77(2), 53-68.

Porral, C. C., \& Lang, M. F. (2015). Private labels: The role of manufacturer identification, brand loyalty and image on purchase intention. British Food Journal, 117(2), 506522. https://doi.org/10.1108/BFJ-06-2014-0216.

Porter, M. E. (1976). Interbrand choice, strategy, and bilateral market power (No. 146). Harvard University Press.

Porter, S. S., \& Claycomb, C. (1997). The influence of brand recognition on retail store image. Journal of product \& brand management, 6(6), 373- 387.

https://doi.org/10.1108/10610429710190414.

Private label today. (n.d.). Private label popular across Europe. https://www.plmainternational.com/industry-news/private-label-today.

Rafiq, M., \& Collins, R. (1996). Lookalikes and customer confusion in the grocery sector: an exploratory survey. International Review of Retail, Distribution and Consumer Research, 6(4), 329-350. https://doi.org/10.1080/09593969600000038.

Raju, J. S., Sethuraman, R., \& Dhar, S. K. (1995). The introduction and performance of store brands. Management science, 41(6), 957-978. https://doi.org/10.1287/mnsc.41.6.957.

Ren, J., \& Nickerson, J. V. (2019). Arousal, valence, and volume: how the influence of online review characteristics differs with respect to utilitarian and hedonic products. European Journal of Information Systems, 28(3), 272-290.

https://doi.org/10.1080/0960085X.2018.1524419.

Renfrow, J. (2017, April 4). 80\% of shoppers compare prices online before shopping in stores. https://www.fierceretail.com/digital/80-shoppers-do-online-price-comparison-before-storeshopping.

Rezvani, S., Dehkordi, G. J., Rahman, M. S., Fouladivanda, F., Habibi, M., \& Eghtebasi, S. (2012). A conceptual study on the country of origin effect on consumer purchase intention. Asian Social Science, 8(12), 205-215. https://doi.org/10.5539/ass.v8n12p205. 
Richardson, P. S., Dick, A. S., \& Jain, A. K. (1994). Extrinsic and intrinsic cue effects on perceptions of store brand quality. Journal of marketing, 58(4), 28-36.

https://doi.org/10.1177/002224299405800403.

Richardson, P. S., Jain, A. K., \& Dick, A. (1996). Household store brand proneness: a framework. Journal of retailing, 72(2), 159-185. https://doi.org/10.1016/S00224359(96)90012-3.

Richins, M. L. (1983). Negative word-of-mouth by dissatisfied consumers: A pilot study. Journal of marketing, 47(1), 68-78. https://doi.org/10.1177/002224298304700107.

Richter, F. (2020, February 18). China Is the World's Manufacturing Superpower [Digital image]. Statista. https://www.statista.com/chart/20858/top-10-countries-by-share-of-globalmanufacturing-output/.

Rodríguez-Díaz, M., Rodríguez-Díaz, R., \& Espino-Rodríguez, T. F. (2018). Analysis of the online reputation based on customer ratings of lodgings in tourism destinations. Administrative sciences, 8(3), 51. https://doi.org/10.3390/admsci8030051.

Rotar, A. (2020). eCommerce Report 2020: Electronics \& Media.

file:///H:/study_id38341_ecommerce-report-electronics-and-media\%20(1).pdf.

Rousell, D., \& White, R. (1970). Private Label Reviewed. J. Walter Thompson Company Limited.

Rubio, N., \& Yagüe, M. J. (2009). Alternative panel models to evaluate the store brand market share: evidence from the Spanish market. European Journal of Marketing, 43 (1/2), 110 138. https://doi.org/10.1108/03090560910923265.

Russell, J. A., \& Mehrabian, A. (1974). Distinguishing anger and anxiety in terms of emotional response factors. Journal of consulting and clinical psychology, 42(1), 79.

https://doi.org/10.1037/h0035915.

Sabanoglu, T. (2010). Global retail e-commerce market share of Amazon from 2016 to 2019. Statista. $\quad$ https://www.statista.com/statistics/955796/global-amazon-e-commerce-marketshare/.

Samiee, S. (2011). Resolving the impasse regarding research on the origins of products and brands. International Marketing Review, 28(5), 473-485.

https://doi.org/10.1108/02651331111167598.

Saridakis, C., \& Baltas, G. (2016). Modeling price-related consequences of the brand origin cue: An empirical examination of the automobile market. Marketing Letters, 27(1), 77-87. https://doi.org/10.1007/s11002-014-9304-3.

Schmalensee, R. (1978). A Model of Advertising and Product Quality. The Journal of Political Economy, 86(3), 485-503. https://doi.org/10.1086/260683. 
Selnes, F. (1993). An Examination of the Effect of Product Performance on Brand Reputation, Satisfaction and Loyalty. The Journal of Product \& Brand Management, 2(4), 45-60. https://doi.org/10.1108/EUM0000000002981.

Semeijn, J., Van Riel, A. C., \& Ambrosini, A. B. (2004). Consumer evaluations of store brands: effects of store image and product attributes. Journal of retailing and Consumer Services, 11(4), 247-258. https://doi.org/10.1016/S0969-6989(03)00051-1.

Sethuraman, R. (2001). What makes consumers pay more for national brands than for store brands-image or quality? Review of Marketing Science WP, (318).

http://dx.doi.org/10.2139/ssrn.310883.

Sethuraman, R., \& Raju, J. S. (2012). Private label strategies-myths and realities. Handbook of marketing strategy. Edward Elgar Publishing.

Shapiro, C. (1983). Premiums for High Quality Products as Returns to Reputations. The Quarterly Journal of Economics, 98(4), 659-679. https://doi.org/10.2307/1881782.

Silver, L., Devlin, K., \& Huang, C. (2019). Attitudes toward China. Pew Research Centre. https://www.pewresearch.org/global/2019/12/05/attitudes-toward-china-2019/.

Sinha, I., \& Batra, R. (1999). The effect of consumer price consciousness on private label purchase. International journal of research in marketing, 16(3), 237-251.

https://doi.org/10.1016/S0167-8116(99)00013-0.

Smith, D., Menon, S., \& Sivakumar, K. (2005). Online peer and editorial recommendations, trust, and choice in virtual markets. Journal of interactive marketing, 19(3), 15-37. https://doi.org/10.1002/dir.20041.

Steenkamp, J. B. E. (1990). Conceptual model of the quality perception process. Journal of Business research, 21(4), 309-333. https://doi.org/10.1016/0148-2963(90)90019-A.

Steenkamp, J. B. E., \& Dekimpe, M. G. (1997). The increasing power of store brands: building loyalty and market share. Long range planning, 30(6), 917-930.

https://doi.org/10.1016/S0024-6301(97)00077-0.

Steenkamp, J. B. E., Van Heerde, H. J., \& Geyskens, I. (2010). What makes consumers willing to pay a price premium for national brands over private labels?. Journal of marketing research, 47(6), 1011-1024. https://doi.org/10.1509/jmkr.47.6.1011.

Steiner, R. L. (2004). The nature and benefits of national brand/private label competition. Review of Industrial Organization, 24(2), 105-127.

https://doi.org/10.1023/B:REIO.0000033351.66025.05.

Sullivan, M. (1990). Measuring image spill overs in umbrella-branded products. Journal of Business, 309-329. http://www.jstor.org/stable/2353152. 
Tandon, S. (2020, Feb 26). Private labels to help drive profitable growth for e-commerce marketplaces: Report. https://www.livemint.com/industry/retail/pvt-labels-to-help-driveprofitable-growth-for-e-commerce-marketplaces-report-11582728645180.html.

Tarzijan, J. (2004). Strategic effects of private labels and horizontal integration. The International Review of Retail, Distribution and Consumer Research, 14(3), 321-335. https://doi.org/10.1080/09593960410001678372.

Thompson, S. (1999). The New Private Enterprise. Brandweek, 40(18), 36-40.

Tran, L. T. T. (2020). Online reviews and purchase intention: A cosmopolitanism perspective. Tourism Management Perspectives, 35, 100722.

https://doi.org/10.1016/j.tmp.2020.100722.

Tse, D. K., \& Gorn, G. J. (1993). An experiment on the salience of country-of-origin in the era of global brands. Journal of International Marketing, 1(1), 57-76.

https://doi.org/10.1177/1069031X9300100105.

Vahie, A., \& Paswan, A. (2006). Private label brand image: its relationship with store image and national brand. International Journal of Retail \& Distribution Management, 34 (1), 6784. https://doi.org/10.1108/09590550610642828.

Varini, K., \& Sirsi, P. (2012). Social media and revenue management; where should the two meet?. Journal of Technology Management for Growing Economies, 3(1), 33-46.

https://doi.org/10.15415/jtmge.2012.31002.

Ventre, I., \& Kolbe, D. (2020). The impact of perceived usefulness of online reviews, trust and perceived risk on online purchase intention in emerging markets: A Mexican perspective. Journal of International Consumer Marketing,32(4), 287-299. https://doi.org/10.1080/08961530.2020.1712293.

Verhoef, P. C., Nijssen, E. J., \& Sloot, L. M. (2002). Strategic reactions of national brand manufacturers towards private labels: An empirical study in The Netherlands. European Journal of Marketing, 36(11/12), 1309-1326. https://doi.org/10.1108/03090560210445191.

Verlegh, P. W., \& Steenkamp, J. B. E. (1999). A review and meta-analysis of country-of-origin research. Journal of economic psychology, 20(5), 521-546. https://doi.org/10.1016/S01674870(99)00023-9.

Walsh, G., \& Mitchell, V. W. (2010). Consumers' intention to buy private label brands revisited. Journal of General Management, 35(3), 3-24. http://doi.org/10.1509/jim.14.0036.

Woodside, A. G. (2012). Consumer evaluations of competing brands: Perceptual versus predictive validity. Psychology \& Marketing, 29(6), 458-466.

https://doi.org/10.1002/mar.20534. 
Wu, P. C., Yeh, G. Y. Y., \& Hsiao, C. R. (2011). The effect of store image and service quality on brand image and purchase intention for private label brands. Australasian Marketing Journal (AMJ), 19(1), 30-39. https://doi.org/10.1016/j.ausmj.2010.11.001.

Ye, Q., Law, R., Gu, B., \& Chen, W. (2011). The influence of user-generated content on traveller behavior: An empirical investigation on the effects of e-word-of-mouth to hotel online bookings. Computers in Human behavior, 27(2), 634-639.

https://doi.org/10.1016/j.chb.2010.04.014.

Yelkur, R., Chakrabarty, S., \& Bandyopadhyay, S. (2006). Ethnocentrism and buying intentions: Does economic development matter?. Marketing Management Journal, 16(2).

Yoon, E., Guffey, H. J., \& Kijewski, V. (1993). The effects of information and company reputation on intentions to buy a business service. Journal of Business research, 27(3), 215228. https://doi.org/10.1016/0148-2963(93)90027-M.

Zeithaml, A. V. (1988). Consumer Perceptions of Price, Quality, and Value: A Means-End Model and Synthesis of Evidence. Journal of Marketing, 52(3), 2-22.

https://doi.org/10.1177/002224298805200302.

Zhu, F., \& Zhang, X. (2010). Impact of online consumer reviews on sales: The moderating role of product and consumer characteristics. Journal of marketing, 74(2), 133-148.

Zhu, L., Li, H., Wang, F. K., He, W., \& Tian, Z. (2020). How online reviews affect purchase intention: a new model based on the stimulus-organism-response (SOR) framework. Aslib Journal of Information Management, 72(4), 463-488. https://doi.org/10.1108/AJIM-11-20190308 .

Zikmund, W., D’Alessandro, S., Winzar, H., Lowe, B., \& Babin, B. (2017). Marketing Research. Cengage Learning. 